University of New Mexico

UNM Digital Repository

Earth and Planetary Sciences ETDs

Electronic Theses and Dissertations

$12-1-2002$

\title{
Proterozoic Farwell Mountain-Lester Mountain suture zone, northern Colorado : subduction flip and progressive assembly of arcs
}

Amanda Tyson

Follow this and additional works at: https://digitalrepository.unm.edu/eps_etds

\section{Recommended Citation}

Tyson, Amanda. "Proterozoic Farwell Mountain-Lester Mountain suture zone, northern Colorado : subduction flip and progressive assembly of arcs." (2002). https://digitalrepository.unm.edu/eps_etds/94

This Thesis is brought to you for free and open access by the Electronic Theses and Dissertations at UNM Digital Repository. It has been accepted for inclusion in Earth and Planetary Sciences ETDs by an authorized administrator of UNM Digital Repository. For more information, please contact disc@unm.edu. 
Proterozoic Farwell Mountain - Lester Mountain Suture Zone, Northern Colorado: Subduction Flip ANd Progressive AsSembly OF ARCS

\author{
BY \\ AMANDA R. TYSON \\ B.S. Geology-Biology, Brown University, May 1997 \\ B.A. Russian Language and Literature, Brown University, May 1997
}

\title{
THESIS
}

Submitted in Partial Fulfillment of the Requirements for the Degree of Master of Science

Earth and Planetary Sciences

The University of New Mexico

Albuquerque, New Mexico

December 2002

Thesis Committee:

Karl E. Karlstrom

Jane Selverstone

Mousumi Roy 


\section{ACKNOWLEDGEMENTS}

Research was supported by the National Science Foundation Continental Dynamics Program EAR-9614787 and EAR-0003540, Geological Society of America Research Grant 7041-01, the Department of Earth and Planetary Sciences at the University of New Mexico, and the Wyoming Geological Association David Love Field Geology Fellowship.

I would like to thank my thesis advisor and committee members, Karl Karlstrom, Jane Selverstone, and Mousumi Roy for sharing their knowledge, guidance, and constructive criticism. I would also like to recognize my field assistants, Sarah Garlick and Joshua Schwartz, for their excellent work (and company) in the field. And many thanks and best wishes to the people in this department who have made my time here so pleasant and who always make the harder times seem easier. 


\begin{abstract}
The mechanisms by which juvenile Paleoproterozoic continental crust was derived from the mantle, accreted to southwestern Laurentia ca. 1.78-1.68 Ga, and stabilized as new continental lithosphere have been much debated. This study addresses the problem by assessing the proposed Paleoproterozoic "Farwell Mountain-Lester Mountain suture zone," a broad, complex zone of deformation that may contain the oldest accretionary structures within Paleoproterozoic crust south of the Cheyenne belt.

The proposed "suture zone" is mapped in the Park Range of northern Colorado as a northeast-trending belt of imbricated tectonic slivers between ca. 1.79-1.77 Ga Green Mountain rocks to the north and ca. 1.76-1.72 Ga rocks to the south. Marble, chert, mafic to ultramafic bodies, deformed pillow basalts, and sulfide deposits all outcrop along the zone and may represent dismembered ophiolites.

One of the major contributions of this study is the correlation of metamorphic and deformational fabrics among four field subareas (Farwell Mountain, Lester Mountain, Mica Basin, and the Soda Creek - Fish Creek shear zone), in an attempt to investigate the history and character of the proposed "suture zone." Steepening and overprinting by an east-west-striking, subvertical fabric is attributed to post-accretionary shortening ca. 1.68 Ga. Also documented is an earlier Paleoproterozoic ductile fabric (" $\mathrm{S}_{2} / \mathrm{F}_{2}$ "), which may preserve evidence of a north-vergent fold and thrust system. This is consistent with the hypothesis that the region has a collisional accretionary history.

Seismic data from the CD-ROM experiment reveal north-dipping reflections that are tentatively associated with a 3-5 km offset of the Moho and a north-dipping, highvelocity body and are together referred to as the Farwell Mountain backthrust. Another set of reflections dip southward and project to the surface near Lester Mountain; these are tentatively correlated with the " $\mathrm{S}_{2}$ " fabric. Together, these features may record the juxtaposition of two tectonic blocks along south-dipping structures in the proposed suture zone ca. $1.74 \mathrm{Ga}$.

A tectonic model is proposed to explain the geometries outlined by combined surface geologic and seismic data from the Cheyenne belt and Farwell Mountain - Lester Mountain "suture zone," allowing some investigation of the early tectonic history of the region despite overprinting by subsequent tectonism.
\end{abstract}




\section{TABLE OF CONTENTS}

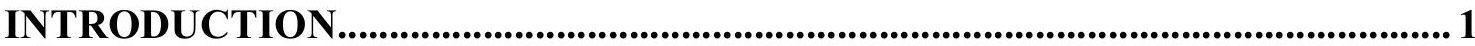

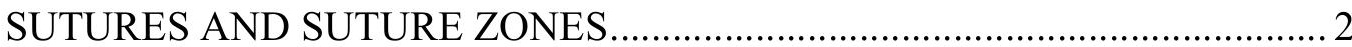

PROPOSED "FARWELL MOUNTAIN - LESTER MOUNTAIN SUTURE

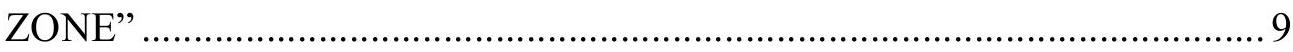

OVERALL SUMMARY ........................................................................................................ 16

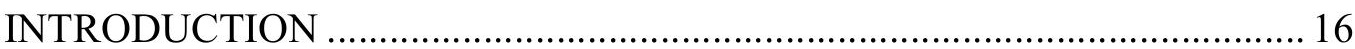

GEOLOGIC EVIDENCE FOR TECTONIC BOUNDARIES............................ 18

SEISMIC EVIDENCE FOR DEEP CRUSTAL BOUNDARIES ........................21

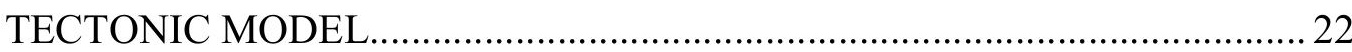

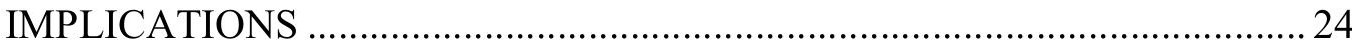

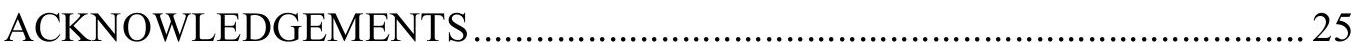

\section{APPENDICES}

Appendix A. Contributions of Previous Work to the Evidence for the

"Farwell Mountain - Lester Mountain suture zone" .................................... 27

Appendix B. Field Maps and Geologic Cross section .......................................52

Appendix C. Sample Location Maps and Sample lists.......................................5 54

Appendix D. Structural and Geochronologic Evidence for Deformational

History

Appendix E. Monazite Dating and Other Geochronologic Data ....................... 119

Appendix F. Seismic Line and Combined Cross Section................................... 129

Appendix G. Tectonic Model ..................................................................... 130

REFERENCES................................................................................................................ 134 


\section{LIST OF FIGURES AND PLATES \\ All Plates in Inside of Back Cover}

Figure 1. Location map ............................................................................ 10

Figure 2. Combined geologic and seismic cross section .............................. 13

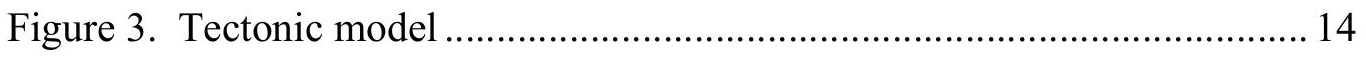

Appendix $A$

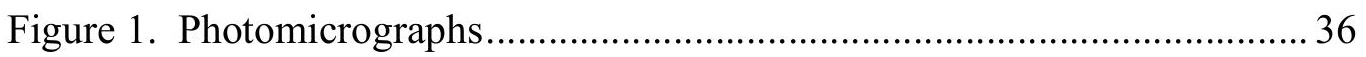

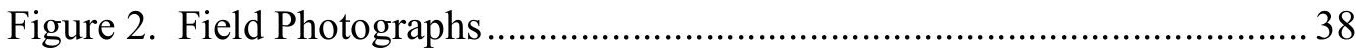

Figure 3. Pressure-temperature paths based on previous work....................... 45

Appendix B

Plate 1. Geologic Maps

a. Park Range and Sierra Madre regional geologic map showing CD-ROM seismic line and geologic cross section line

b. Mica Basin field map

c. Lester Mountain field map

Plate 2. Geologic Cross Section (1:48,000 scale) with insets for Lester Mountain and

Mica Basin areas

Appendix $C$

Plate 3. Sample Location Map: Farwell Mountain area

Plate 4. Sample Location Map: Pearl area

Plate 5. Sample Location Map: Mica Basin area

Plate 6. Sample Location Map: Lester Mountain area

Plate 7. Sample Location Map: Soda Creek - Fish Creek Shear zone 


\section{LIST OF FIGURES AND PLATES, continued.}

Appendix D

Figure 1. Pressure-Temperature-time-Deformation Paths .............................. 64

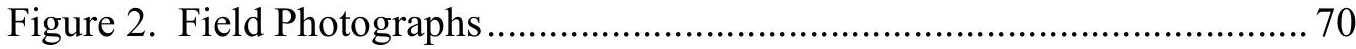

Plate 8. Regional Form Surface Map of Foliation Trajectories

Figure 3. Stereonet Plots for the Farwell Mountain area ............................... 73

Figure 4. Stereonet Plots for the Mica Basin area ........................................ 76

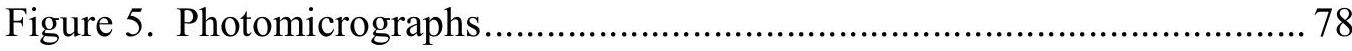

Figure 6. Stereonet Plots for the Lester Mountain area ................................. 90

Figure 7. Stereonet Plots for the Soda Creek - Fish Creek shear zone ............. 95

Appendix E

Figure 1. Slide Scan and Photomicrograph of Sample K98-PK-27a.............. 121

Figure 2. Images of Monazite Grains Dated on the Microprobe .................... 123

Figure 3. ${ }^{39} \mathrm{Ar} /{ }^{40} \mathrm{Ar}$ Sample Locations and Results .................................... 127

Appendix $F$

Plate 9. Seismic Reflection Profile (1:48,000 scale) with Outlines of Geologic Cross Section Superimposed

Appendix $G$

Figure 1. Scale Drawing of a Typical Island Arc 130 


\section{LIST OF TABLES}

Table 1. Proposed sutures .............................................................................. 3

Appendix $A$

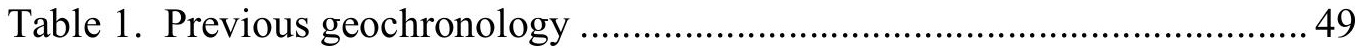

Table 2. Fabrics and Timing for the Soda Creek - Fish Creek Shear Zone ...... 50

Appendix $C$

Table 1. Sample List for 2000-2001 Field Season........................................... 55

Table 2. Sample List for 1998-1999 Field Season......................................... 58

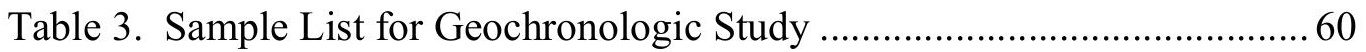

Appendix D

Table 1. Thin Section Descriptions for Samples Collected 2000-2001 .......... 101

Table 2. Thin section Descriptions for Samples Collected 1998-1999 ........... 106

Table 3. Summary of Fabrics and Timing for all Subareas ........................... 108

Table 4. Summary of Timing of Metamorphic Mineral Growth .................... 109

Table 5. Structural data: Summary of Field Measurements .......................... 110

Appendix E

Table 1. Monazite Dating Results......................................................... 124

Table 2. ${ }^{39} \mathrm{Ar} /{ }^{40} \mathrm{Ar}$ Cooling Ages for Park Range Samples............................ 126 


\section{INTRODUCTION.}

The continental lithosphere of the southwestern U.S.A. consists mainly of ca. 1.8$1.65 \mathrm{Ga}$ crust that is thought to have been derived from the mantle as oceanic and arc terranes shortly before it was assembled to the southwestern margin of the Laurentian Archean craton (DePaolo, 1981; Aleinikoff et al., 1993). This implies that a 150 m.y. period of tectonism produced a $\sim 1200-\mathrm{km}$-wide belt of new, thick, stable, segmented continental lithosphere in the Proterozoic (Bowring and Karlstrom, 1990). It is hypothesized that accretionary boundaries between lithospheric segments that were established during the period of Paleoproterozoic continental assembly have greatly influenced the expression of subsequent tectonic events (Karlstrom and Humphreys, 1998; Karlstrom and the CDROM Working Group, 2002). Because currently exposed rocks resided at middle-crustal depths in the Paleo- to Mesoproterozoic, the evidence for reactivation of high-strain zones during multiple ductile deformations (e.g. Shaw et al., 2001; Selverstone et al., 2000) provides insight into not only the accretionary process, but also the nature of long-lived weakness in the middle crust (Karlstrom and Williams, in press).

The most viable model for the amalgamation of juvenile continental material into stable, segmented continental lithosphere over a time span of hundreds of millions of years involves the collision of a variety of largely juvenile tectonic elements such as magmatic arcs and oceanic plateaus with the rifted Archean margin of southwestern Laurentia. This “Indonesian model” for crustal growth (Karlstrom, 1989; Jessup et al., 2002) suggests that once-separate segments of lithosphere should be identifiable as blocks of contrasting geologic origins and histories separated by "sutures" that should be 
recognizable as major tectonic boundaries (Condie, 1982, 1992; Karlstrom and Bowring, 1988, 1993; Shaw and Karlstrom, 1999).

However, no sutures have been clearly identified in the southwestern U.S. south

of the Cheyenne belt, and there has been little consensus on either the location or geometry of possible sutures and accreted terranes. Various independent lines of geologic evidence have been used to search for sutures, including geochronologic, isotopic, metamorphic, structural, xenolith, and geophysical data. The challenge is to integrate different types of data to distinguish blocks or terranes of similar character and to constrain the locations of possible sutures between them. Numerous workers have studied major tectonic boundaries and considered them as possible sutures within Proterozoic crust of the southwestern U.S.A. (Table 1). However, no discrete sutures have yet been identified or agreed upon. The problem of identifying sutures is compounded by the fact that during suturing, present outcrops were at 10-20 km depths, where suture zones may be distributed zones of tectonic mixing (Karlstrom and Williams, 1998). Also, early subhorizontal boundaries tend to be steepened and obscured when overprinted by crustal shortening structures (Shaw and Karlstrom, 1999). Evidence for the continued residence of present outcrops at middle-crustal depths well into the Meso- or Neo-Proterozoic suggests that their accretionary fabric would have been vulnerable to overprinting by subsequent tectonic events during that time.

\section{SUTURES AND SUTURE ZONES}

For the purpose of this study, a broad definition of the term "suture" is invoked. Here, the basic principle is that a "suture" is a boundary separating two blocks of crust 
Table 1: Sutures and important tectonic boundaries proposed in Paleoproterozoic crust of the southwestern U.S.A.

\begin{tabular}{|c|c|c|c|}
\hline Authors & Date & Proposed boundary & Evidence Presented \\
\hline Silver & 1965 & $\begin{array}{l}\text { Yavapai-Mazatzal boundary in the } \\
\text { Four Corners Area }\end{array}$ & $\mathrm{U}-\mathrm{Pb}$ zircon geochronologic provinces \\
\hline Condie & 1982 & Accretion of arcs & No sutures identified \\
\hline Bennett and DePaolo & 1987 & Major Nd provinces & $\begin{array}{l}\mathrm{TDM}(?) \text { ages from Nd analysis of of plutonic and } \\
\text { supracrustal rocks }\end{array}$ \\
\hline $\begin{array}{l}\text { Karlstrom and } \\
\text { Bowring }\end{array}$ & 1988 & $\begin{array}{l}\text { Major orogenic provinces - Mojave, } \\
\text { Yavapai, Mazatzal }\end{array}$ & $\begin{array}{l}\text { Shear zones separate tectonic blocks (as suspect } \\
\text { terranes) but no "sutures" identified }\end{array}$ \\
\hline Dann & 1991 & Payson ophiolite & Ophiolite as inter-arc basin. No suture identified. \\
\hline Wooden and DeWitt & 1991 & $\begin{array}{l}\text { Mojave and central Arizona } \\
\text { Provinces, western Arizona }\end{array}$ & $\mathrm{Pb}$ isotopic data \\
\hline Condie & 1992 & $\begin{array}{l}\text { Terrane boundaries in various } \\
\text { orientations \& locations }\end{array}$ & Geochronology and geochemistry of volcanic rocks \\
\hline $\begin{array}{l}\text { Karlstrom and } \\
\text { Bowring }\end{array}$ & 1993 & $\begin{array}{l}\text { Major orogenic provinces - Mojave, } \\
\text { Yavapai, Mazatzal }\end{array}$ & $\begin{array}{l}\text { Shear zones separate tectonic blocks (as suspect } \\
\text { terranes) but no "sutures" identified }\end{array}$ \\
\hline Reed et al. & 1993 & Arc - back-arc - arc & $\begin{array}{l}\mathrm{U}-\mathrm{Pb} \text { zircon geochronology patterns: southward } \\
\text { younging and alternating belts of dominantly } \\
\text { igneous vs. sedimentary rocks }\end{array}$ \\
\hline Ilg et al. & 1996 & Crystal shear zone, Grand Canyon & $\begin{array}{l}\text { Contrasting pluton and supracrustal rock ages, } \\
\text { structural and metamorphic history, sharp } \\
\text { differences in } \mathrm{Pb} \text { isotopes }\end{array}$ \\
\hline $\begin{array}{l}\text { Karlstrom and } \\
\text { Williams, in press; }\end{array}$ & 1996 & \multirow{2}{*}{$\begin{array}{l}\text { Two broad transitional major } \\
\text { - boundary zones: Mojave-Yavapai and } \\
\text { Yavapai-Mazatzal }\end{array}$} & \multirow{2}{*}{$\begin{array}{l}\text { Sutures represent zones of tectonic mixing at middle- } \\
\text { crustal levels }\end{array}$} \\
\hline $\begin{array}{l}\text { Karlstrom and } \\
\text { Humphreys }\end{array}$ & 1998 & & \\
\hline Foster et al. & 1999 & $\begin{array}{l}\text { Farwell-Lester Mountain zone or } \\
\text { Soda Creek-Fish Creek shear zone in } \\
\text { the Park Range, Colorado }\end{array}$ & $\begin{array}{l}\text { contrast in age across region; metamorphic field } \\
\text { gradient; high-strain zones with histories of multiple } \\
\text { deformation events }\end{array}$ \\
\hline Selverstone et al. & 1999 & $\begin{array}{l}\text { Yavapai-Mazatzal boundary in the } \\
\text { Four Corners Area }\end{array}$ & $\begin{array}{l}\text { Xenolith data show different P-T paths across } \\
\text { boundary. Hydrated xenoliths and eclogites to the } \\
\text { north suggest N-dipping subduction zone. }\end{array}$ \\
\hline Shaw and Karlstrom & 1999 & $\begin{array}{l}\text { Diffuse Yavapai-Mazatzal boundary } \\
\text { zone in the Southern Rocky } \\
\text { Mountains (Colorado) }\end{array}$ & $\begin{array}{l}\text { Synthesis of geochronologic, isotopic, geochemical } \\
\text { and xenolith data with structural and metamorphic } \\
\text { history }\end{array}$ \\
\hline Selverstone et al. & 2000 & $\begin{array}{l}\text { Moose Mountain shear zone, } \\
\text { Colorado Front Range }\end{array}$ & $\begin{array}{l}\text { Difference in zircon ages and structural histories of } \\
\text { supracrustal rocks, evidence for sinistral motion on a } \\
\sim 1.7 \text { Ga shear zone }\end{array}$ \\
\hline $\begin{array}{l}\text { Cavosie and } \\
\text { Selverstone }\end{array}$ & 2002 & $\begin{array}{l}\text { Buckhorn Creek shear zone, Colorado } \\
\text { Front Range }\end{array}$ & $\begin{array}{l}\text { Possible ophiolite fragments, high-temperature strike- } \\
\text { slip fabrics predate dip-slip fabrics, MORB } \\
\text { geochemistry }\end{array}$ \\
\hline
\end{tabular}


that once resided on different plates or microplates and have since been tectonically juxtaposed. In general, intracontinental "sutures" tend to be broad "suture zones" with complex histories of deformation. There are two end-member types of plate interactions that may juxtapose two blocks of crust from different plates: (1) "collisional," involving closure of an ocean basin via subduction and the resulting collision of continents with other continents or island arcs; and (2) "transform," involving the juxtaposition of unrelated, possibly far-traveled blocks (e.g. microplates) by transcurrent motion along a transform plate boundary. As used here, the term "suture zone" carries no assumptions with regard to the relative contributions of convergent vs. transcurrent motion during continental assembly.

In contrast, some authors (e.g. Dewey 1977) assign the term "suture" only when referring to a "collisional" suture that represents the consumption of oceanic lithosphere by subduction and subsequent collision of blocks of continental crust. Dewey (1977) further differentiates between "terminal" and "pre-terminal" sutures: "terminal sutures" are established at the end of a long period of subduction and collision that culminates in a continental collision. "Pre-terminal sutures," then, are structural boundaries related to events that occur repeatedly during progressive collisional tectonism, such as the opening and closing of back arc basins, collision of an island arc with a rifted continental margin and an associated flip in subduction polarity, arc-arc collision, or collision of an island arc with an Andean-style arc with the same subduction polarity (Dewey, 1977).

All of these "pre-terminal" and "terminal" types of sutures fall within the general category of "suture zones" for the purpose of this study. Also included in this general definition of "suture zone" are any boundaries created by the accretion (to continental 
margins) of tectonic elements other than island arcs, e.g. continental microplates or oceanic plateaus. The latter are poorly understood and may have a variety of origins ranging from continental to oceanic; regardless, they seem to play a significant role in assembling continental crust (e.g. in the Canadian Cordillera) and can cause significant penetrative deformation during collision with a continental margin (Nur et al., 1982).

It is a common misconception that a suture must be expressed at the surface as a mylonite zone. The outcomes of this study lend support to the argument that a "suture zone" can be a wide, distributed zone with a complex deformation history. The proposed "Farwell Mountain - Lester Mountain suture zone," in fact, is a diffuse zone of tectonic imbrication with an inferred duplex-style geometry and without distinct boundaries. There is no discrete mylonitic shear zone in this region that would explain the deep crustal geometries imaged by seismic studies. Conversely, by no means should all mylonitic shear zones be considered as possible suture zones. In this study area, the Soda Creek - Fish Creek shear zone contains a concentration of anastomosing mylonite strands, yet it does not separate blocks of contrasting geologic character, nor does it correlate to deep structures imaged by the seismic studies. (It should be noted here that the shear zone is subvertical and would not be imaged by reflection seismic if it continues to dip steeply at depth in the crust.) This and comparable shear zones in Colorado, if they indeed date back to the history of suturing, may have been intracontinental structural zones which accommodated either transform motion along plate (or microplate) boundaries or strike-slip motion related to escape tectonics within the orogen. It is also possible that they originated within a system of more shallowly dipping, thrust-sense structures during assembly, and have since been rotated into steeper orientations and been 
concentrated into narrower high-strain zones due to subsequent shortening. In either case, these shear zones are not potential "suture zones" unless it can be demonstrated that they separate blocks of contrasting geologic origin.

Much controversy has arisen over the role of ophiolites in the identification of sutures. The strictly-defined "collisional" suture is expected to contain ophiolites; "transform" sutures and "pre-terminal sutures" may contain them as well. In suture zones of various geologic age and setting around the world, the occurrences and preservation of ophiolites are variable, they are often deformed and tectonically thinned and/or dismembered, and the mechanism(s) of their emplacement are much debated (Moores, 1982). Geochemical studies have not resolved a single source for ophiolites; among the possibilities are mid-ocean ridge basalts, back-arc basins, primitive island arcs, or oceanic plateaus. Proposed models show ophiolites being emplaced on continental crust by various mechanisms at various times during the suturing process (Moores, 1982), illustrating that the timing and kinematics of ophiolite emplacement are far from agreed upon. Thus, although the presence of ophiolites is generally considered to be consistent with the location of a suture zone, they may have a complex tectonic history and geologic relationship to the juxtaposed blocks and alone may not lead to a definitive conclusion on either the nature or location of a suture.

The best alternative, therefore, is to incorporate as many independent lines of evidence as possible to characterize both the potential "suture zone" and the geologic contrasts across it, be they lithologic, geochronologic, isotopic, geochemical, structural, stratigraphic, metamorphic, tectonic, paleomagnetic, seismic, or geophysical. Workers around the world have used various combinations of these lines of evidence to argue for 
the location and nature of sutures of all geologic ages. Commonly, as investigation of a potential suture proceeds, its geometry and history is discovered to be more complex than previously thought. In some cases, further study challenges even the presence of a suture at all. One of these cases is the Teslin Suture Zone, a 15-km-wide, several-hundred-kmlong zone with a complex history of pure and simple shear that has been interpreted to be the suture between the North American craton and accreted terranes in the Canadian Cordillera (e.g. Erdmer, 1985; Oliver et al., 2001). A later, detailed field-based study unraveled a complex deformation history of at least four major regional events, leading to the argument that the area delineated as the Teslin Suture Zone actually represents postaccretionary strain partitioning and is not a suture at all (de Keijzer et al., 2001).

Many sutures have been proposed based on seismic data in conjuction with other geophysical data, and, where available, surface geology. Some examples include the Taconic suture between Laurentian crust and Avalonia in the Appalachians (EDGE seismic experiment, e.g. Sheridan et al., 1993), the Silurian-Devonian Iapetus suture in the northern British Isles (British Institutions Reflection Profiling Syndicate and Caledonian Suture Seismic Project; e.g. Beamish and Smythe, 1986; Klemperer and Matthews, 1987; Soper et al., 1982; Freeman et al., 1988; Klemperer, 1989; Chadwick and Holliday, 1991; and Livelybrooks and Banks, 1995), an arc-continent suture related to the Main Uralian Fault in the Southern and Middle Urals (Ayarza et al., 2000), and a crustal-scale collisional suture between two terranes in the Paleoproterozoic TransHudson orogen in Canada (LITHOPROBE study; White et al., 2000).

The interpretations of modern-day suturing events are becoming more sophisticated, now that the Global Positioning System (GPS) can be used to monitor plate 
motions. When combined with other geologic and geophysical data, workers can recognize additional complexities and accordingly refine models for suturing [e.g. the collision of the Banda and Sunda arcs with the Australian continental margin (Genrich et al., 1996; Snyder et al., 1996) and the Taiwan orogeny (Ding et al., 2001)].

Isotopic data have also been widely used to try to constrain possible paleo-suture locations at the surface. One example is the delineation of the western Idaho suture zone as a zone of isotopic mixing separating continental and oceanic terranes with distinct $\mathrm{Sr}$ and Nd isotopic signatures in Neogene volcanic rocks; Leeman et al (1992) explain this mixing zone as the complex surface expression of a shallowly west-dipping boundary along which oceanic lithospheric mantle was thrust eastward over old continental lithospheric mantle of North America. This example emphasizes that suturing along shallow boundaries can cause complex transition zones (e.g. Shaw and Karlstrom, 1999) at any exposed structural level, a point that must be seriously considered when studying the surface geology in a proposed suture zone.

The assembly history of the Canadian Cordillera involved the amalgamation of a variety of terranes, including approximately $60 \%$ juvenile arc-related rocks, and may thus be a good analog for the history of assembly of the southwestern U.S. in the Proterozoic (Samson and Patchett, 1991). Interestingly, despite the relative youth of the Cordillera and the much shallower structural levels exposed, it has been difficult to identify definitive suture zones between tectonostratigraphic terranes in this belt as well. The roles of the large-displacement (on the order of $500 \mathrm{~km}$ ) dextral transcurrent faults in the Cordillera are widely debated; currently they accommodate strain related to the component of Pacific Plate motion parallel to the continental margin of Canada and 
southeast Alaska. Were some of the terranes in the Cordillera originally juxtaposed along these transcurrent boundaries, or have they only been shuffled along strike-slip faults as part of a complex history of strain partitioning during long-lived tectonism?

Of course, these are two end-member scenarios, but it is important to consider that analogous processes may have been involved in the Proterozoic assembly history of southwestern Laurentia. This study attempts to constrain one small part of this assembly history by combining a variety of geologic and geophysical data that have been generated by workers over the past several decades. While recognizing the possible limitations in our ability to conclusively determine the location and tectonic history of a suture zone, this study contributes (1) evidence for the regional kinematic history and (2) a synthesis of all available data to aid in the development of tectonic models to explain the geometries observed at and beneath the surface.

\section{PROPOSED “FARWELL MOUNTAIN - LESTER MOUNTAIN SUTURE ZONE”}

The best-established major Paleoproterozoic suture in the southwestern U.S.A. is the Cheyenne belt (Figure 1), which marks the juxtaposition of accreted Proterozoic terranes with the Archean Wyoming craton to the north (see Appendix A; Houston et al., 1979; Hills and Houston, 1979; Karlstrom and Houston, 1984). In the Sierra Madre of southwestern Wyoming (Appendix B, Plate 1a), the block to the north of the Cheyenne belt is the Archean Wyoming Province overlain by sediments of the Paleoproterozoic miogeocline; the block to the south contains the 1.79-1.77 Ga Green Mountain Formation and related plutons. (Graff, 1978, Karlstrom and Houston 1979). Timing of deformation in the Cheyenne belt is constrained to 1.78-1.75 Ga (Chamberlain, 1998). 


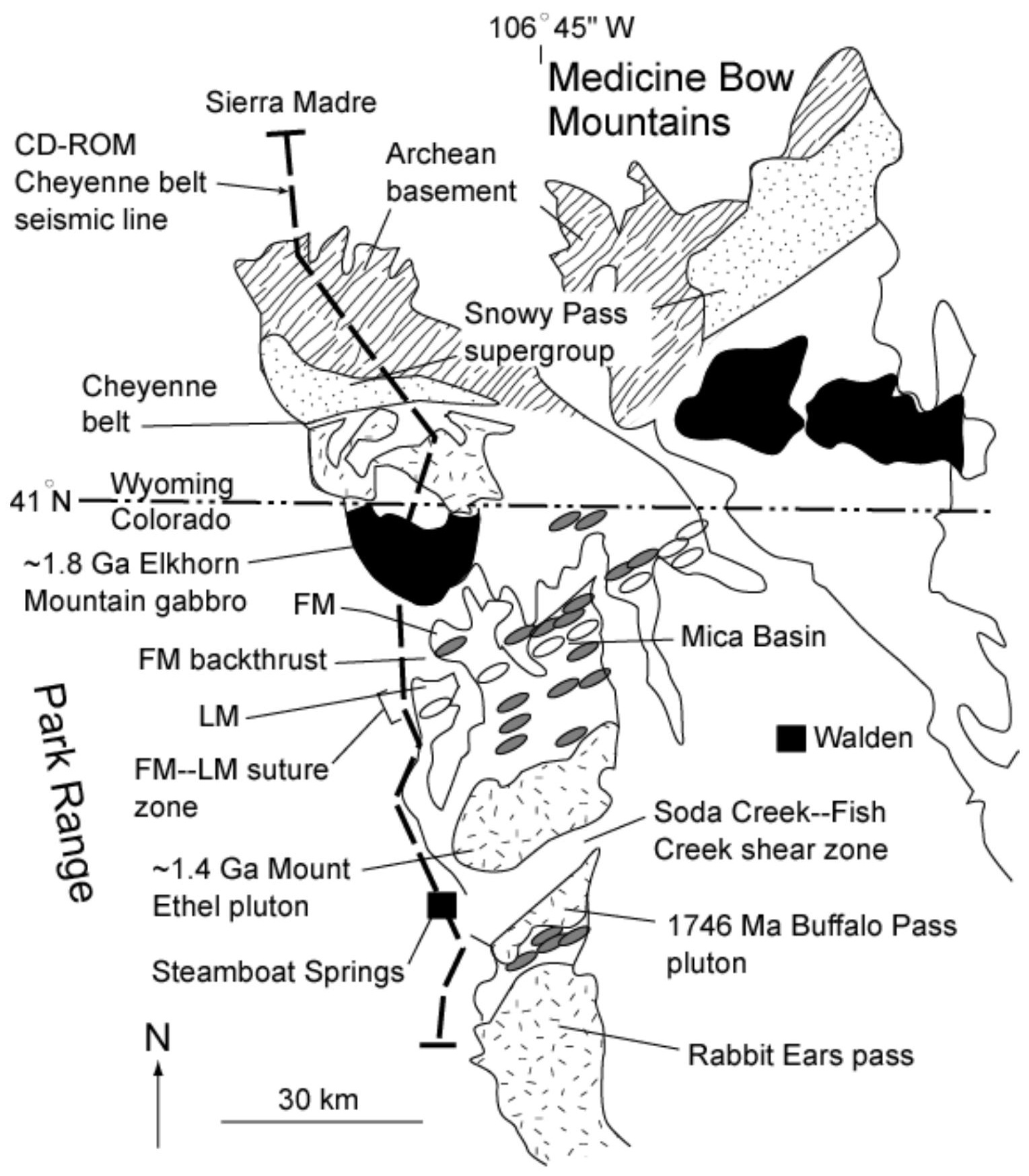

Figure 1 (Tyson et al., 2002). Location map with CD-ROM Cheyenne belt seismic line and geologic cross section line in Sierra Madre, Wyoming and Park Range, Colorado (dashed line). Open ovals---rock with sillimanite pods, gray ovals---pillow basalt and ultramafic rocks, black---layered maficultramafic complexes, FM---Farwell Mountain, LM---Lester Mountain. 
South of the Cheyenne belt is the proposed "Farwell Mountain-Lester Mountain suture zone" in the Northern Park Range, Colorado (Figure 1), which has been hypothesized to contain the most northerly and possibly the oldest set of Paleoproterozoic sutures within juvenile Proterozoic crust in the southwestern U.S.A. (Tyson et al., 2002). The main body of this paper is excerpted from Tyson et al. (2002). Its purposes are (1) to summarize all available sets of structural, lithologic, metamorphic, and geochronologic data that have led to this interpretation; (2) to integrate surface geologic with seismic reflection (Morozova et al., 2002), refraction (Snelson et al., 2001), and receiver functions (Dueker et al., 2001) that were produced by the CD-ROM experiment (Keller et al., 1999); (3) to propose a tectonic model to explain the observed geometries of the Cheyenne belt and Farwell Mountain-Lester Mountain zone based on a synthesis of geologic and seismic data; and (4) to evaluate the character and geometry of these and other possible middle-crustal suture zones, assessing implications for the process of building continental lithosphere.

My personal contributions to the evidence presented in this thesis are discussed in detail in the appendices. Appendix A contains a compilation of information from the literature that is relevant to the interpretation of the Farwell Mountain-Lester Mountain suture zone. It also includes a brief summary of the characteristics of the Cheyenne belt, a good template for hypotheses about other sutures of similar age in the region. The data collected during my two summer field seasons are represented by detailed field maps and cross sections of targeted areas within the field area (Appendix B) and a list of samples collected (Appendix C). The detailed composite geologic cross section at 1:48,000 scale (Appendix B, Plate 2) through the major Precambrian exposures of interest in the 
southern Sierra Madre and northern and central Park Range (Appendix B, Plate 1) is based on the new, detailed geologic maps combined with those of Snyder (1980) and Houston and Graff (1995).

Appendix D elaborates on structural and microstructural analyses for rocks from each of the key portions of the field area using stereonets, sketches, photographs, and photomicrographs. Pressure-temperature-time-deformation (P-T-t-D) paths are constructed for each subarea. Preliminary monazite dates for a schist from Lester Mountain and a summary of the monazite dating method can be found in Appendix E, along with tables summarizing other sources of Proterozoic timing data for the Park Range.

It should be emphasized that significant results of this study have materialized during the process of compiling new geologic data with geologic and seismic data collected by other workers. Part of my work has been to register the geologic cross section line with the CD-ROM Cheyenne belt seismic line and to combine the seismic reflection (Appendix F, Plate 9), refraction, teleseismic and tomographic data with the geologic data (Figure 2) to resolve geometries in the crust and mantle that may represent Paleoproterozoic structures. Appendix G contains further discussion of the tectonic model presented in Figure 3.

Without the data and hypotheses presented by the following previous workers (see also Appendix A), this project would have been much more limited in its scope. George L. Snyder's (1980) excellent and thorough geologic maps of the Park Range at 1:48,000 scale were an excellent basis from which to generate hypotheses to focus field questions and target key areas for detailed mapping. Previous studies of the structural and 


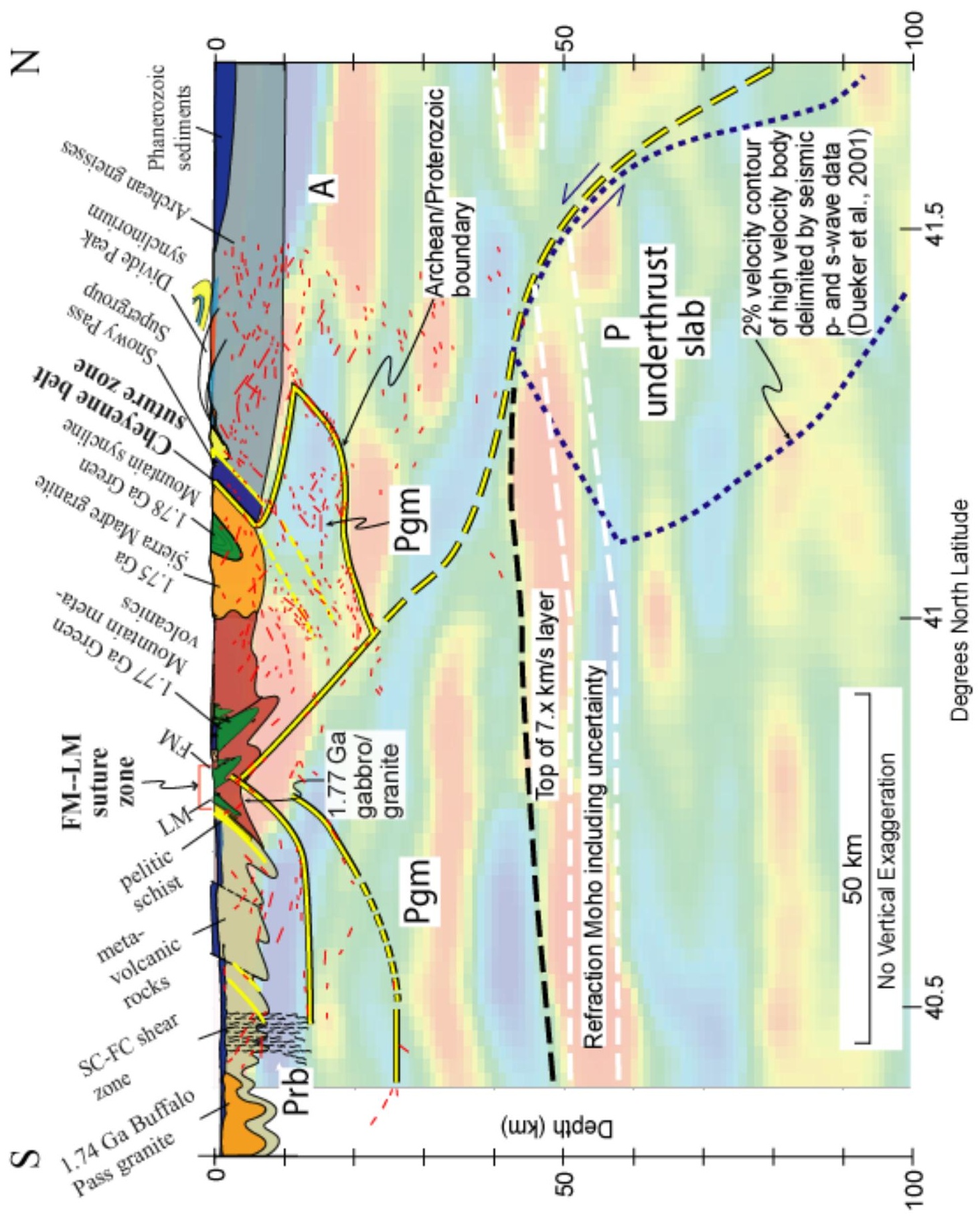

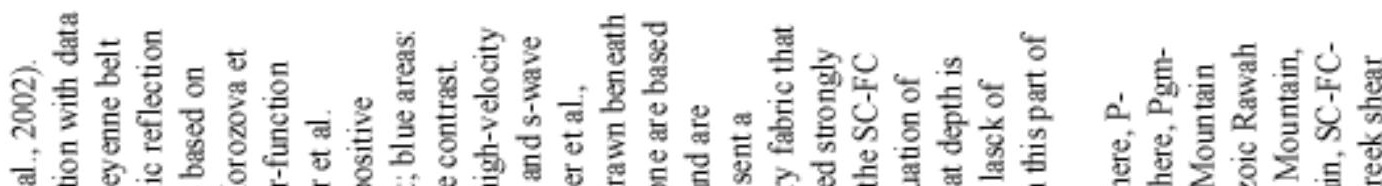

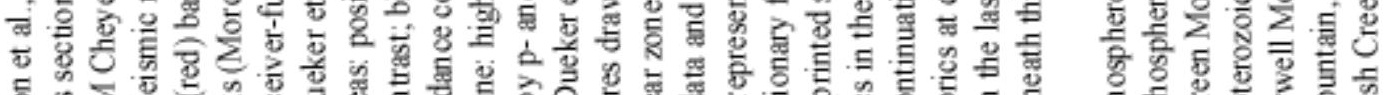

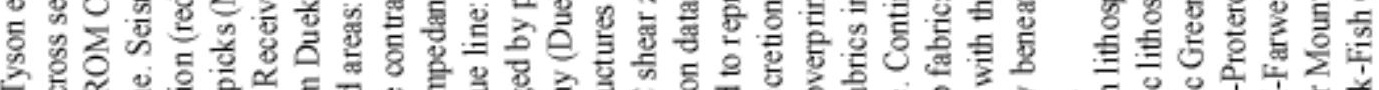

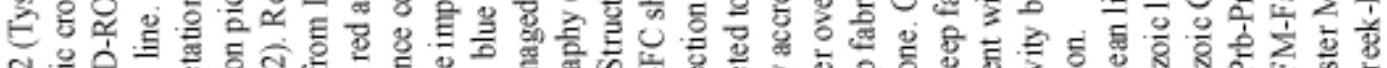

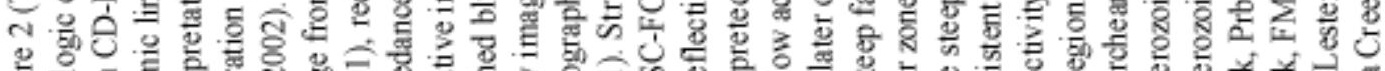

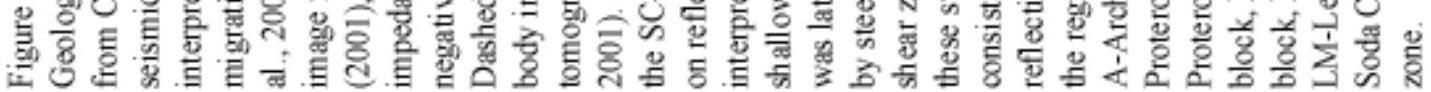




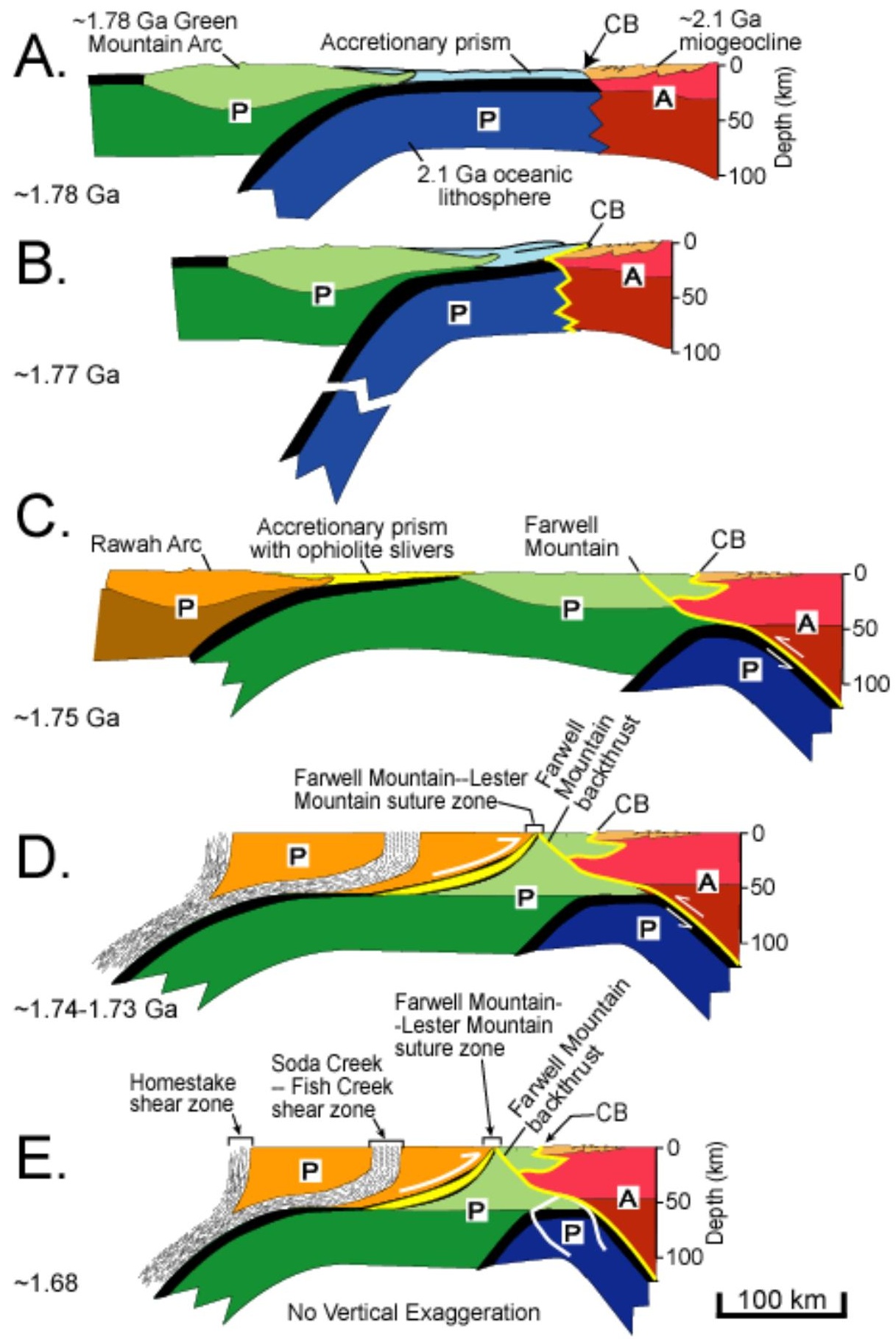

Figure 3 (Tyson et al., 2002). One possible plate-tectonic model to explain observed geometries in the crust and upper mantle of the region. A: Archean (A) margin and Paleoproterozoic (P) miogeocline. Green Mountain arc built (1.79-1.77 Ga) as ocean basin closed. B: Subduction ceased as craton margin reached trench $(1.77-1.76 \mathrm{Ga})$. C: Green Mountain arc crust interwedged with Archean margin by 1.75 $\mathrm{Ga}$ and ca. $2.1 \mathrm{Ga}$ oceanic lithosphere underthrust northward. D: 1.76-1.72 Ga Rawah arc collided with continental margin (1.746-1.74 Ga). E: Shortening steepened fabrics. Homestake shear zone correlates to south-dipping slab. CB-Cheyenne belt. 
metamorphic geology of various Paleoproterozoic exposures in the Park Range were conducted by C.T. Foster and students ${ }^{1}$. Among the significant results of these studies was the identification of a metamorphic break between Farwell Mountain and Lester Mountain and the recommendation of Foster et al. (1999) that this region be targeted for future investigation as a potential suture within Paleoproterozoic crust.

Seismic refraction (Snelson et al., 2001), reflection (Morozova et al., 2002), and passive source seismic data (Dueker et al., 2001) from the CD-ROM Cheyenne belt line together singled out the zone between Farwell and Lester Mountains as a likely area of tectonic significance. All of the new seismic data together with the various lines of geologic evidence presented an important opportunity to interpret the deformational history preserved in the surface geology in conjunction with deep crustal geometries.

Geochronologic constraints on the structural fabrics observed in the field are mainly from the work of Kevin Chamberlain using metamorphic sphene and $\mathrm{U}-\mathrm{Pb}$ zircon dating (Appendix C, Table 3; Appendix A, Table 1). It should also be noted that some structural data and a number of samples were collected by Karl Karlstrom and Kevin Chamberlain during reconnaissance of the Park Range in 1998-1999 (Appendix C, Table 2), prior to my work here. I have examined the thin sections, hand samples, and field notes from these trips and included them in my structural analyses in Appendix D.

\footnotetext{
${ }^{1}$ M.S. or senior honors' theses of C.T. Foster's students at University of Iowa provided geologic data for the following key locations on which this investigation has been focused: Eiler (1989) and Chaplinsky (1987) — Soda Creek — Fish Creek shear zone; Barinek (1997) — Mount Ethel pluton; Kennedy (1992) Mica Basin; Rougvie, (1990) — marbles and calc-silicates; Smith (1990)—Farwell Mountain; White (1987) — Lester Mountain; Klipfel (1992) - encampment district. Refer to Appendix A for a more detailed review of their contributions.
} 
OVERALL SUMMARY

Excerpted from Tyson, et al. (2002).

PROTEROZOIC FARWELL MOUNTAIN-LESTER MOUNTAIN SUTURE ZONE, NORTHERN COLORADO: SUBDUCTION FLIP AND PROGRESSIVE ASSEMBLY OF ARCS

Tyson, A.R. ${ }^{1}$, Morozova, E.A. ${ }^{2}$, Karlstrom, K.E. ${ }^{1}$, Chamberlain, K.R. ${ }^{2}$, Smithson, S.B. ${ }^{2}$, Dueker, K.G. ${ }^{2}$, Foster, C.T., Department of Geology, University of Iowa, Iowa City, IA 52242

${ }^{1}$ Department of Earth and Planetary Sciences, University of New Mexico, Albuquerque, NM 87131

${ }^{2}$ Department of Geology and Geophysics, University of Wyoming, Laramie, WY 82071

\section{INTRODUCTION}

The history and processes of growth of the southwestern U.S.A. continental lithosphere are poorly understood, despite the efforts of many workers over the past few decades. Geochronologic, $\mathrm{Nd}$ (DePaolo, 1981), and Pb (Aleinikoff et al., 1993) isotopic data indicate that southwestern U.S.A. crust is largely ca. $1.8-1.65$ Ga material that was assembled to the Archean core of Laurentia soon after it was derived from the mantle. Pre-1.8 Ga crust is present locally in the primarily 1.8-1.65 Ga juvenile orogen (e.g. 1.84 
Ga Elves Chasm pluton, Grand Canyon; Hawkins et al., 1996), possibly in the central Colorado subsurface, as indicated by inherited zircons (2520-2000 Ma and 1878-1814 Ma in ca. 1.75 Ga rocks; Hill and Bickford, 2001) and Sm-Nd model ages (e.g. 2.5-1.8 Ga model ages; Hill and Bickford, 2001). One hypothesis to explain the growth of southwestern Laurentia is that a protracted orogenic episode of accretion of various arc and oceanic elements to the Wyoming craton from 1.78-1.65 Ga culminated in the stabilization of a $1200-\mathrm{km}$-wide segment of new continental lithosphere (Condie, 1982; Karlstrom and Bowring, 1988). In this case, the Cheyenne belt suture zone (Fig. 1) marks the juxtaposition of accreted Proterozoic terranes with the Archean Wyoming craton (Hills and Houston, 1979; Karlstrom and Houston, 1984) ca. 1.78-1.75 Ga (Chamberlain, 1998). An alternate hypothesis is that semi-continuous older crust is present in the subsurface beneath the Proterozoic orogen (e.g. 1.9-1.8 Ga Trans-Hudson-Penokean basement) and the Cheyenne belt is older $(\sim 1.8 \mathrm{Ga})$ or is not a suture (Hill and Bickford, 2001).

To evaluate these models, knowledge of the location, geometry, and timing of sutures is required. Tectonic models for crustal growth by collision of multiple plates predict that sutures separate original tectonic elements. However, it has been difficult to identify Paleoproterozoic sutures in the southwestern U.S.A. The lack of agreement on the location and nature of sutures is due in part to the disparate lines of evidence (geochronologic, isotopic, xenolith, metamorphic, seismic, and structural) used to propose them and the similarity in ages across possible boundaries. Because exposed rocks were at middle-crustal depths during deformation, paleosutures may be broad zones of tectonic mixing (Karlstrom and Williams, 1998). Residence of these rocks in the 
middle crust from 1.75-1.4 Ga means that subsequent deformation, including transcurrent motion syn- or post-suturing (Selverstone et al., 2000), may obscure accretionary boundaries.

The CD-ROM (Continental Dynamics of the Rocky Mountains) experiment was designed to apply geologic and geophysical methods to evaluate sutures (Karlstrom and the CD-ROM working Group, 2002). This paper presents combined structural, petrologic, and geochronologic data from the Cheyenne belt line (Fig. 1) and integrates them with seismic reflection data (Morozova et al., 2002) and tomographic and teleseismic images (Dueker et al., 2001). We propose that the "Farwell Mountain-Lester Mountain suture zone" in the Northern Park Range, Colorado (Fig. 1) is part of a wide ArcheanProterozoic suture zone containing the northernmost and possibly oldest major accretionary structures within Paleoproterozoic crust south of the Cheyenne belt.

\section{GEOLOGIC EVIDENCE FOR TECTONIC BOUNDARIES}

Our cross section in the Sierra Madre of southern Wyoming and Park Range of northern Colorado (Figs. 1,2) crosses several potential suture zones (Hills and Houston, 1979; Foster et al., 1999). We address the geology of proposed tectonic blocks and boundaries from north to south.

The Archean Wyoming province consists of $>2.7$ to $2.5 \mathrm{Ga}$ basement overlain by the 2.4-2.1 Ga miogeoclinal Snowy Pass Supergroup, preserved in the Sierra Madre as a wedge of subvertically foliated rock at the south edge of the Archean block (Fig. 2). The Cheyenne belt is a set of steeply south-dipping amphibolite-grade shear zones that deform the miogeoclinal rocks and Archean and Proterozoic gneisses. Steep stretching 
lineations and shear sense features indicate south-side-up motion. Timing of deformation is constrained by deformed 1.78 Ga rocks and the undeformed 1.75 Ga Sierra Madre granite (Chamberlain, 1998). Two $40^{\circ}$-south-dipping reflectors extend from the Cheyenne belt (at the surface) to $\sim 15 \mathrm{~km}$ depths (Fig. 2; Morozova et al., 2002).

South of the Cheyenne belt is the ca. 1.79-1.78 Ga (Premo and Van Schmus, 1989) Green Mountain Formation, interlayered calc-alkalic (Condie and Shadel, 1984), bimodal, subaerial and submarine volcanic and volcaniclastic rocks and volcanogenic massive sulfide deposits. Condie and Shadel (1984) inferred that the bimodal magmas sampled different levels of an andesitic magma chamber undergoing fractional crystallization in a mature island arc or continental margin arc setting, citing the layered gabbros as cumulates. U-Pb zircon ages for the Elkhorn Mountain gabbro (Fig. 1) are $1774 \pm 2 \mathrm{Ma}$ (quartz diorite phase) and $1768 \pm 8 \mathrm{Ma}$ (gneissic inclusion; Pallister and Aleinikoff, 1987). Its $\mathrm{Pb} / \mathrm{Pb}$ age is $1781 \mathrm{Ma}$ (Snyder, 1980). The $1769 \pm 6 \mathrm{Ma}$ (Pallister and Aleinikoff, 1987) deformed quartz monzonite of Seven Lakes is commingled with and intrudes the gabbro. These 1.78-1.77 Ga plutons and the Green Mountain Formation are exposed no further south than Farwell Mountain and Mica Basin (Fig. 1; Snyder, 1980). Nd data indicate that these rocks were not derived from older crust (Chamberlain, 1998).

Foster et al. (1999) proposed a tectonic boundary between Farwell and Lester Mountains on the basis of a lithologic contrast and metamorphic grade change. Lester Mountain supracrustal rocks are volcaniclastic schists, pelitic schists, metamorphosed turbidites and quartzite. "Exotic" rock types crop out along the Farwell Mountain-Lester Mountain suture zone (Fig. 1). Interlayered marble, amphibolite, calc-silicate, and 
metachert may be altered marine exhalites (Foster et al., 1999). "Siliceous pod rock" (Snyder, 1988) has a quartz + feldspar + mica matrix surrounding "pods" of quartz + sillimanite \pm muscovite and may record hydrothermal alteration. There are pods and boudins of small mafic-ultramafic bodies, including chromite- or spinel-bearing amphibole peridotites, orthoamphibole-rich rocks, dunite, wehrlite, and harzburgite (Snyder, 1980), and deformed pillow basalts. We interpret these as tectonic slivers of ophiolite within a sedimentary accretionary complex.

The Farwell Mountain-Lester Mountain suture zone contains several tectonite fabric generations; it is not a single shear zone. Lester Mountain supracrustal rocks contain a shallowly south-dipping $\mathrm{S}_{2}$ fabric that is axial-planar to north-verging, subrecumbent, isoclinal folds $\left(\mathrm{F}_{2}\right)$. The $\mathrm{F}_{2}$ folds deform a composite $\mathrm{S}_{0}-\mathrm{S}_{1}$ fabric and are folded and transected by a steeply south-dipping, northeast-striking $\mathrm{S}_{3}$ foliation. We hypothesize that the $F_{2}$ structures are the surface expression of the south-dipping seismic reflectors (Fig. 2), representing a north-vergent fold-and-thrust system that juxtaposed contrasting lithologic packages. The $\mathrm{S}_{3}$ foliation may represent the shortening and steepening of fabrics due to continuing convergent tectonism.

In the Rawah block to the south, supracrustal rocks $(<1.76 \mathrm{Ga})$ and granites (1.746 and $1.735 \mathrm{Ga}$; Premo and Van Schmus, 1989) are younger than rocks to the north and bear higher peak metamorphic assemblages. North of the suture, at Farwell Mountain, supracrustal rocks bear greenschist-grade assemblages with average peak garnet-biotite temperatures of $\sim 495^{\circ} \mathrm{C}$ (Foster et al., 1999). South of the suture, at Lester Mountain, upper amphibolite grade sillimanite and staurolite assemblages with garnetbiotite temperatures of $\sim 575^{\circ} \mathrm{C}$ and $\sim 625^{\circ} \mathrm{C}$ and GASP pressures of $\sim 5$ kbar overprint 
relict kyanite and staurolite, indicating an earlier $>625^{\circ} \mathrm{C},>6$ kbar event (Foster et al., 1999). We interpret this contrast to represent conditions during a $1.68 \mathrm{Ga}$ event that reactivated the structural boundary, based on ca. $1.680 \mathrm{Ma}$ sphene dates in the Soda Creek-Fish Creek shear zone $30 \mathrm{~km}$ to the south (Chamberlain, personal communication, 2002).

The subvertical, northeast-trending Soda Creek-Fish Creek shear zone (Fig. 1) is a 6-km-wide ductile high strain zone (Snyder, 1980). A 1.74 Ga U-Pb date (Chamberlain, unpublished data) from a pegmatite dike that crosscuts the ca. $1746 \mathrm{Ma}$ Buffalo Pass granite with a weak deflection of $\mathrm{S}_{1}$ constrains $\mathrm{S}_{1}-\mathrm{D}_{1}$ to $1.746-1.74 \mathrm{Ga}$. A syn- $\mathrm{S}_{2}$ hornblende-pegmatite dike yields a U-Pb date of $1.68 \mathrm{Ga}$, similar to $1.68 \mathrm{Ga}$ metamorphic sphene dates (Chamberlain, personal communication, 2002). Mylonite strands $\left(\mathrm{S}_{3}\right)$, pseudotachylyte, and cataclasite crosscut $\mathrm{S}_{1}$ and $\mathrm{S}_{2}$ and are inferred to be synkinematic with the adjacent ca. 1.42 Ga Mount Ethel pluton based on mutually crosscutting relationships between mylonites and ca. 1.42 Ga mafic dikes (Snyder 1980).

\section{SEISMIC EVIDENCE FOR DEEP CRUSTAL BOUNDARIES}

The CD-ROM seismic line (Fig. 1) crosses the Cheyenne belt in the Sierra Madre and continues south through and $\leq 5 \mathrm{~km}$ west of Proterozoic exposures in the Park Range (Fig. 1). Morozova et al. (2002) interpreted the Archean-Proterozoic boundary to be a linked set of oppositely dipping reflections (Fig. 2) coinciding with a contrast between highly reflective crust to the north (arcuate criss-crossing patterns) and poorly reflective crust to the south. Proterozoic and Archean crust are shown to be inter-wedged along 
conjugate thrusts (Fig. 2), similar to the geometry of Archean-Proterozoic sutures in the SNORCLE LITHOPROBE line (Cook et al., 1998). To the south, inferred Proterozoic crust reveals south-dipping reflections that surface at the Cheyenne belt and northdipping reflections that surface near Farwell Mountain. The north-dipping reflections reach $22 \mathrm{~km}$ depths (Fig.2) (Morozova et al., 2002) and we speculate that they correlate to a 3-5 $\mathrm{km}$ north-side-up step in the Moho and the top of a north-dipping slab-shaped high-velocity mantle anomaly that reaches $200 \mathrm{~km}$ depth (Dueker et al., 2001; Karlstrom and the CD-ROM Working Group, 2002). We hypothesize that this north-dipping feature represents underthrusting of ca. 2.1 Ga oceanic lithosphere northward beneath the craton margin. Shear wave splits are consistent with a steeply north-dipping mantle anisotropy beneath the Cheyenne belt (Fox, et al., 2001). This supports the interpretation that the high-velocity body is Proterozoic in age and due to anisotropic olivine fabric, not modern temperature variations.

A set of south-dipping reflections extend to $\sim 22 \mathrm{~km}$ depths and project to the surface near Lester Mountain. They are interpreted to express the contrast between juxtaposed metasedimentary and metavolcanic packages in a broad suture zone that separates the Green Mountain arc from the Rawah block. The lack of strong reflections beneath the Soda Creek-Fish Creek shear zone is presumably due to the dominance of steep fabrics.

\section{TECTONIC MODEL}

Our tectonic model uses as a modern analog the collision of the Australian plate margin with the Banda arc at a north-dipping subduction zone in the Indonesian 
archipelago. Snyder et al. (1996) proposed that this subduction zone ceased activity when the full-thickness Australian continental crust reached the trench and collided with the island of Timor ca. 2.2 Ma. Continued convergence led to backstepping of the trench system and uplift. Snyder et al. (1996) suggested that a flip in subduction polarity caused the zone of upper crustal deformation to shift northward, producing a broad zone of deformation (shown by seismicity, e.g. McCaffrey, 1988). They infer that the present deformation involves the beginning of southward underthrusting of the arc beneath already-accreted Timor and the continental margin.

We propose a similar scenario for the assembly of Proterozoic crust at the Cheyenne belt and Farwell Mountain-Lester Mountain suture zone. Figure 3A shows a thinned (post-2.1 Ga rifting) craton margin on which the Paleoproterozoic Snowy Pass Supergroup (miogeocline) was deposited. The ocean basin closed via the south-dipping subduction system that built the Green Mountain arc at 1.79-1.77 Ga. Evidence for this is the lack of voluminous Paleoproterozoic felsic intrusions to the north. Figure 3B shows the craton margin approaching the trench at $1.77-1.76 \mathrm{Ga}$ and the ceasing of southdipping subduction. Figure 3C shows the collision of the Green Mountain arc with the craton margin. The remaining ca. $2.1 \mathrm{Ga}$ oceanic lithosphere was underthrust northward. By 1.75 Ga (age of the post-tectonic Sierra Madre granite), movement at the Cheyenne belt and Farwell Mountain backthrust ceased and Green Mountain arc crust was wedged into Archean crust along conjugate thrusts. Evidence for this is the contrasting seismic reflectivities across the Archean-Proterozoic boundary. Evidence for the underthrust "slab" is the high-velocity body (Fig. 2), shown here as a piece of Proterozoic oceanic mantle adjacent to Archean mantle, not a mature subduction zone, due to the lack of 
Paleoproterozoic magmatism above it. Figure 3D shows that the 1.76-1.72 Ga Rawah arc from the south collided with the Proterozoic continental margin at $1.746-1.74 \mathrm{Ga}\left(\mathrm{S}_{1} / \mathrm{D}_{1}\right.$ in the Soda Creek-Fish Creek shear zone). Figure 3E shows the steepening of accretionary structures ca. $1.68 \mathrm{Ga}$ due to continued convergent tectonism.

\section{IMPLICATIONS}

Although geologic studies identified the Farwell Mountain-Lester Mountain suture zone and the Soda Creek-Fish Creek shear zone as potential sutures, it is reflection data that reveal the Farwell Mountain-Lester Mountain suture zone as the major tectonic boundary that penetrates much of the crust. The combined geologic and seismic data can be explained by a tectonic model for complex inter-wedging during suturing of arcs that is compatible with modern analogs and other Archean-Proterozoic sutures.

Testable predictions for our tectonic model along the existing seismic transect include (1) verification of the geochronologic break across the Farwell Mountain-Lester Mountain suture zone, (2) geochemistry of ultramafic bodies and pillow volcanic rocks consistent with an ophiolitic origin, and (3) kinematic and geochronologic studies of in situ monazite to test for synchronous conjugate shearing at 1.78-1.76 Ga. More seismic work is required to determine whether the proposed geometry persists along-strike. If so, we predict (4) Proterozoic mantle xenoliths and evidence for lower-crustal hydration beneath the southern Wyoming Province (Leucite Hills and Cedar Mountain localities) and Archean xenoliths in northernmost Stateline diatremes (Lester and Farmer, 1998), and (5) mixed $\mathrm{Nd}$ signatures for late- to post-tectonic plutons in the inter-wedging zone 
for a considerable distance south of the Cheyenne belt, as in the Medicine Bow and Laramie Range (Chamberlain, 1998).

\section{ACKNOWLEDGEMENTS}

Research was supported by the National Science Foundation Continental Dynamics Program EAR-9614787 and EAR-0003540, Geological Society of America Research Grant 7041-01, the Department of Earth and Planetary Sciences at the University of New Mexico, and the Wyoming Geological Association David Love Field Geology Fellowship. We thank Dave Snyder, Pat Bickford, and Sam Bowring for helpful reviews. 


\section{LIST OF APPENDICES}

Appendix A. Contributions of Previous Work to the Evidence for the "Farwell Mountain - Lester Mountain suture zone”

Appendix B. Field Maps and Geologic Cross section

Appendix C. Sample Location Maps and Sample lists

Appendix D. Structural and Geochronologic Evidence for Deformational History

Appendix E. Monazite Dating and Other Geochronologic Data

Appendix F. Seismic Line and Combined Cross Section

Appendix G. Tectonic Model 


\section{APPENDIX A. CONTRIBUTIONS OF PREVIOUS WORK TO THE EVIDENCE FOR THE “FARWELL MOUNTAIN - LESTER MOUNTAIN SUTURE ZONE”}

\section{LITHOLOGIC AND GEOCHRONOLOGIC EVIDENCE FOR BLOCKS AND} TECTONIC BOUNDARIES.

On the basis of a variety of geologic data, several potential suture zones were identified by earlier workers (Hills and Houston, 1979; Houston et al., 1979; Karlstrom and Houston, 1984; Barinek et al., 1999; Foster et al., 1999) in the Sierra Madre of southern Wyoming and Park Range of northern Colorado ${ }^{1}$. Proposed tectonic blocks and boundaries in this region are described from north to south (Appendix B, Plate 1a) below. This appendix provides a more detailed summary than was possible in the concise Geology paper.

The Cheyenne belt suture and the blocks it separates are discussed in this section because it is the best-identified Paleoproterozoic suture in the region and thus serves as a template in the identification of other sutures that might have comparable characteristics. Moreover, due to the large scales involved in most plate tectonic processes, it is likely that tectonic events along the Cheyenne belt are linked to the "Farwell Mountain - Lester Mountain suture zone”. The summary below thus begins by describing (1) the Archean Wyoming Province and ca. 2.1 Ga miogeocline and (2) the northeast-trending Cheyenne belt suture. More directly pertaining to the developments in this study are the descriptions of (3) the ca. $1.78 \mathrm{Ga}$ Green Mountain block, consisting of the 1.78-1.77 Ga Green Mountain metavolcanic rocks and 1.78-1.76 Ga Elkhorn Mountain plutonic complex

\footnotetext{
${ }^{1}$ Refer to Table 1 in the main text for a summary of proposed sutures and important tectonic boundaries elsewhere in the southwestern U.S.A.
} 
[Premo and van Schmus, 1989; Pallister and Aleinikoff, 1987; Reed et al., 1987], (4) the northeast-trending Farwell Mountain-Lester Mountain structural zone (Foster et al., 1999), (5) the ca. 1.74 Ga (Premo and van Schmus, 1989) Buffalo Pass/Rabbit Ears pluton (granodiorite/quartz diorite) of the "Rawah" block, and (6) the 6-km-wide Soda Creek-Fish Creek shear zone (Snyder, 1980), a high-strain zone with anastomosing mylonite strands.

\section{Archean Wyoming Province and Paleoproterozoic Miogeocline.}

At the southern margin of the Laurentian craton, directly north of the Cheyenne belt, the Archean basement complex consists mainly of granitic gneiss, quartzofeldspathic gneiss, and migmatite, with scattered occurrences of amphibolite, quartzite, marble, and ultramafic rock (Hills and Houston, 1979, Karlstrom and Houston, 1984). Overlying the basement at the northern edge of the Cheyenne belt are bodies of a Late Archean (2900-2500 Ma) metasedimentary rocks (Karlstrom and Houston, 1984; Hills and Houston, 1979; Houston et al., 1968; Karlstrom, 1977; Graff, 1978), which have been interpreted as a series of sedimentary basins or synclinoria. The Late Archean Phantom Lake Metamorphic Suite shows that this was the locus of the most quartz-rich sediments deposited in the Archean. Paleoproterozoic metasedimentary sequences are best exposed in the Deep Lake (Blackwelder, 1926) and Libby Creek (Houston et al., 1968) Groups of the Medicine Bow Mountains. The Paleoproterozoic Deep Lake Group ranges from 3200-10,000 m thick and is mostly made up of sericitic quartzite, schist, and quartz metaconglomerate (Blackwelder, 1926, Karlstrom and Houston, 1984).

Amygdaloidal metabasalt, possible metatuff, and siliceous marble are present (Houston et al., 1968; Karlstrom, 1977). Large-scale cross beds in the quartzite units suggest a 
shallow marine environment, and there is some evidence for glacial and fluvial deposition as well Flurkey, 1983). The lower Libby Creek Group (Houston et al., 1968) unconformably overlies the Deep Lake Group and is a 3700-m-thick sequence of metamorphosed clastic sedimentary rocks, mainly orthoquartzite with cross beds and ripple marks, micaceous quartzite, quartz-rich schists and phyllite (Hills and Houston, 1979; Houston et al., 1968). Dolomitic marble containing stromatolites (Knight and Keefer, 1966) interbedded with phyllites and slates overlies the clastic sequence. The upper Libby Creek Group consists of chlorite-amphibole schists of possible metavolcanic origin and rare sandstone layers, signifying a change in depositional environment from the stable-shelf, or miogeoclinal, sequence of the lower Libby Creek Group (Hills and Houston, 1979).

In the Sierra Madre, the miogeoclinal Snowy Pass Supergroup is preserved as a $>3000 \mathrm{~m}$ package of subvertically foliated rock at the southern edge of the Archean block. It consists mainly of micaceous quartzites, slate, and phyllite, thought to be metamorphosed clastic sedimentary rocks (Houston et al., 1975; Graff, 1978). Also present are metavolcanics, metalimestones, and metaconglomerates, some of which may be metatillites (Houston et al., 1975; Graff, 1978). This sequence has been correlated unit for unit with the Deep Lake Group in the Medicine Bow Mountains, although the metasediments of the Snowy Pass Supergroup are a more distal facies (Houston and Graff, 1995; Karlstrom and Houston, 1979; Houston et al., 1968; Houston et al., 1975; Graff, 1978). In both cases there are (1) possible intermediate-composition metatuffs and subaerial volcanic flow rocks, (2) pillow lavas, (3) amphibolites, and (4) very few felsic 
intrusive rocks with the exception of the highly sheared Gaps Granite (Karlstrom and Houston, 1984).

The presence of these miogeoclinal sedimentary sequences along the southern margin of the Wyoming craton with progressions from Late Archean possible continental margin deposits upward to Early Proterozoic fluvial and carbonate shelf deposits is suggestive of a depositional setting along a developing continental rift margin (e.g. Karlstrom et al., 1983). Paleocurrent and sedimentary data from the Deep Lake and Libby Creek Groups suggest that they were deposited in a northeast-trending basin (perhaps subparallel to the present orientation of the Cheyenne belt) and were bounded to the south by continental crust of an unknown block (Karlstrom et al., 1983).

Evidence for rifting at ca. $2.0 \mathrm{Ga}$ includes the pervasive tholeiitic sills and dikes that crosscut the metasedimentary rocks and range in age from ca. 2.09-2.01 Ga in the Sierra Madre, Medicine Bow Mountains, and Laramie Range (Houston et al., 1993.; Chamberlain, 1997). Also, a dramatic change in C isotope composition is constrained to ca. 2.1 Ga in the Paleoproterozoic ocean (Karhu, 1993) and C isotope systematics have been used to correlate this to a similar dramatic change in the carbonates of the Snowy Pass Supergroup (Bekker, 2001). Inboard from the inferred rift axis in the Laramie Mountains and Hartville uplift, U-Pb apatite data are consistent with ca. 2.0 Ga unroofing (Chamberlain, 1997). Sphene growth, resetting of $\mathrm{Rb} / \mathrm{Sr}$ systematics, growth of small zircons in cores of hydrothermal apatites, and a correlation between decreasing $\mathrm{Pb} / \mathrm{Pb}$ and increasing common lead in southeastern Wyoming are all consistent with ca. $2.0 \mathrm{Ga}$ hydrothermal activity that could be associated with a rift system (Chamberlain, 1997). 


\section{CHEYENNE BELT SUTURE.}

The Cheyenne belt (Houston et al., 1979; Hills and Houston, 1979; Karlstrom and Houston, 1984) is the surface geologic expression of the suture between the Archean granitic gneisses of the Wyoming Province and overlying rift-margin sediments to the north and Proterozoic volcanogenic supracrustal and plutonic rocks to the south (Hills and Houston, 1979). It is exposed in the Laramide uplifts of southern Wyoming as a series of northeast-trending, steeply southeast-dipping amphibolite-grade shear zones with steep stretching lineations and south-side up shear sense indicators, which deform the miogeoclinal rocks and Archean and Proterozoic gneisses. The suture is identified in the Medicine Bow Mountains (Houston and McCallum, 1961; McCallum, 1964a,b; Duebendorfer and Houston, 1986, 1987) as a 7-km-wide zone of sheared augen gneiss and migmatite with mylonite zones, in the Sierra Madre (Houston et al., 1975; Duebendorfer and Houston, 1990) to the west as mylonite and phyllonite zones on the order of hundreds of meters in width, and in the Laramie Mountains (Hills and Armstrong, 1974) by the ca. 1.4 Ga Laramie Anorthosite-Syenite Complex, which presumably intruded along a pre-existing tectonic boundary. Because there are abundant Paleoproterozoic felsic plutons (making up 50\% of the crust) south of the Cheyenne belt but essentially no calc-alkaline plutons younger than $2400 \mathrm{Ma}$ to the north, the Cheyenne belt has been interpreted as a south-dipping paleosubduction zone (Hills and Houston, 1979) over which Proterozoic tectonic elements rafted in to collide with the craton margin. The abundant kyanite $\leq 10 \mathrm{~km}$ north of the Cheyenne belt (Hills and Houston, 1979), possibly indicating a history of burial followed by heating for the northern block, and two $40^{\circ}$-south-dipping seismic reflectors that extend from the surface trace of the 
Cheyenne belt to $\sim 15-\mathrm{km}$ depths (Morozova et al., 2002) are consistent with southdipping subduction and north-directed thrusting.

Four large and many smaller Paleoproterozoic mafic complexes have been mapped in northern Colorado several tens of kilometers south of the Cheyenne belt. The Lake Owens and Mullen Creek mafic complexes in the Medicine Bow Mountains contain layered cumulates of peridotite, noritic gabbro, and anorthositic gabbro. The Mullen Creek complex and a similar complex in the Sierra Madre are highly deformed and recrystallized and have been heavily intruded by granites. The ca. 1.78-1.77 Ga Elkhorn Mountain complex in the Park Range appears to be much less deformed. It is here considered to be part of the Green Mountain block and will be discussed in more detail below. The Wyoming platinum province coincides in space with the large mafic bodies. (Houston et al., 1975)

\section{GREEN MOUNTAIN BLOCK.}

Rocks exposed south of the Cheyenne belt in the Sierra Madre, first defined by Condie and Shadel (1984), are here considered to be part of the Green Mountain block. They are mainly plagioclase- and hornblende-rich gneisses of unknown origin that may be metamorphosed graywackes or intermediate to mafic volcanic rocks, sillimanite gneiss, amphibolite, biotite-quartz-feldspar gneiss, and minor calc-silicate gneiss, marble, and quartz-rich gneiss. Amygdaloidal lava, tuff, and metaconglomerate have been found in the southern Sierra Madre (Houston et al., 1975).

The age of the Green Mountain block is constrained by the ca. 1.79-1.77 Ga (Premo, 1983; Premo and Van Schmus, 1989) Green Mountain Formation (Divis, 1976). 
It consists of a suite of locally metamorphosed, calc-alkalic (Condie and Shadel, 1984) bimodal (Schmidt, 1983; Houston et al., 1992), interlayered subaerial and submarine volcanic rocks with fluvially reworked volcaniclastic rocks and volcanogenic massive sulfide deposits. This package lies in a northwest-trending syncline and is cut by the posttectonic Encampment River Granodiorite and Sierra Madre Granite (Houston and Graff, 1995). Condie and Shadel (1984) inferred that that the bimodal magmas sampled an andesitic magma chamber undergoing fractional crystallization in a mature island arc or continental margin arc setting and suggested that the layered gabbros in the region could be crustal cumulates. This is supported by recent work by Low et al. (2002).

The Elkhorn Mountain gabbro (diabasic gabbro, diorite, and quartz diorite) of the northernmost Park Range has U-Pb zircon dates of $1774 \pm 2 \mathrm{Ma}$ for a quartz diorite fractionate and $1768 \pm 8$ Ma for a km-scale garnet gneiss inclusion (Pallister and Aleinikoff, 1987). The gabbro itself has a $\mathrm{Pb} / \mathrm{Pb}$ age of $1781 \mathrm{Ma}$ (Snyder, 1980) and is commingled with the deformed Seven Lakes granite (Snyder, 1980; biotite granite, quartz monzonite, and granodiorite). A small body of quartz monzonite, possibly a phase of the Seven Lakes granite, which crosscuts the gabbro has yielded a $1769 \pm 6 \mathrm{Ma}$ U-Pb zircon date (Pallister and Aleinikoff, 1987). We interpret the 1.78-1.77 Ga Elkhorn Mountain and Seven Lakes plutons to be a commingled arc pluton complex that is exposed no further south than Farwell Mountain or Mica Basin, where it intrudes metamorphosed and/or migmatized metavolcanic gneisses and possibly metasedimentary schists (Appendix B, Plate 1a,b; Appendix C, Plate 3; Snyder, 1988). The following discussion (keyed to Plate 1) will describe several areas that were studied in detail in search for the location of the suture zone. 


\section{"FARWell Mountain-Lester Mountain Suture Zone"}

The proposed "Farwell Mountain-Lester Mountain suture zone" is a northeasttrending belt several $\mathrm{km}$ wide which has been mainly studied in the Laramide block uplift exposures at Farwell Mountain, Lester Mountain, and Mica Basin (Appendix B, Plate 1a). It is not a single shear zone; rather, it is interpreted to be a broad zone of tectonic imbrication, possibly due to a history of assembly along shallowly south-dipping boundaries in a north-verging fold and thrust zone. The boundaries of the suture zone are, therefore, difficult to outline, but they are constrained by the outcrop pattern of "exotic" rock types, which are discussed below. The suture zone thus includes the Farwell Mountain (Appendix C, Plate 3) and Mica Basin (Appendix B, Plate 1b) areas (inferred to contain tectonic slices of the Green Mountain block to the north) and the Lester Mountain area (Appendix B, Plate 1c; inferred to contain tectonic slices of the accretionary wedge and Rawah block to the south). These three areas also contain "pods" of fibrous sillimanite, which are flattened in a tectonic fabric interpreted to represent latesyn- to post-accretionary deformation (see Appendix D). It is thus hypothesized that this sillimanite grew during a post-suturing event characterized by heating and channelization of fluids along a pre-existing structural boundary that was related to accretion.

The Soda Creek - Fish Creek shear zone to the south (Appendix C, Plate 7) may also be part of the suture zone; unfortunately it has been strongly overprinted by subsequent deformation events and its vertical nature means that its deep structure (if also steep) cannot be imaged by seismic reflections. Intrusion of the ca. 1.42 Ga Mount Ethel pluton along the northern margin of the shear zone could have been influenced by the 
pre-existence of a major tectonic boundary, but it has also contributed to the obscuring of any accretionary fabric that might have been preserved in the Soda Creek - Fish Creek shear zone.

\section{$\underline{\text { Farwell Mountain and Lester Mountain Areas }}$}

At the top of Farwell Mountain are a coarser-grained, more strongly foliated phase of amphibolitized Elkhorn Mountain gabbro and the Seven Lakes granodiorite (Snyder, 1980a). The country rock is primarily bimodal metavolcanic gneiss. Farwell Mountain metabasalts, which are similar to those in the Green Mountain Formation (Smith, 1990), have high $\mathrm{La} / \mathrm{Nb}$ and $\mathrm{Ba} / \mathrm{La}$ ratios and a whole rock geochemistry and trace element geochemistry consistent with an arc setting (Foster et al., 1999). Unique to this area (and the northern half of Lester Mountain) is a rhyo-dacitic conglomerate/agglomerate (Figure 1a; Snyder, 1980) including polymictic conglomerate and/or oligomictic agglomerate with round, angular, flattened, or stretched cobbles or volcanic bomb fragments, spatially associated with feldspar-quartz-muscovite-podbearing rocks. These are interpreted to be Green Mountain arc volcanic rocks intruded by the Elkhorn Mountain/Seven lakes plutonic complex. U-Pb dating (Chamberlain) will be used to test this interpretation.

The supracrustal rocks at Lester Mountain are strikingly different from those to the north in that they include distinctly pelitic schists and a lens of meta-quartzite (see Appendix D, Figure 5h), in addition to metavolcanic gneisses and schists. The quartziteschist package is inferred to have been a basal turbidite gradational with interbedded sandstones and shales and a cross-bedded quartz arenite (Foster et al., 1999). Multi-grain 
Figure 1. Photomicrographs to show lithology.

a. (K01-LM-29, right) finegrained felsic metavolcanic gneiss (Xca) from Lester Mountain.

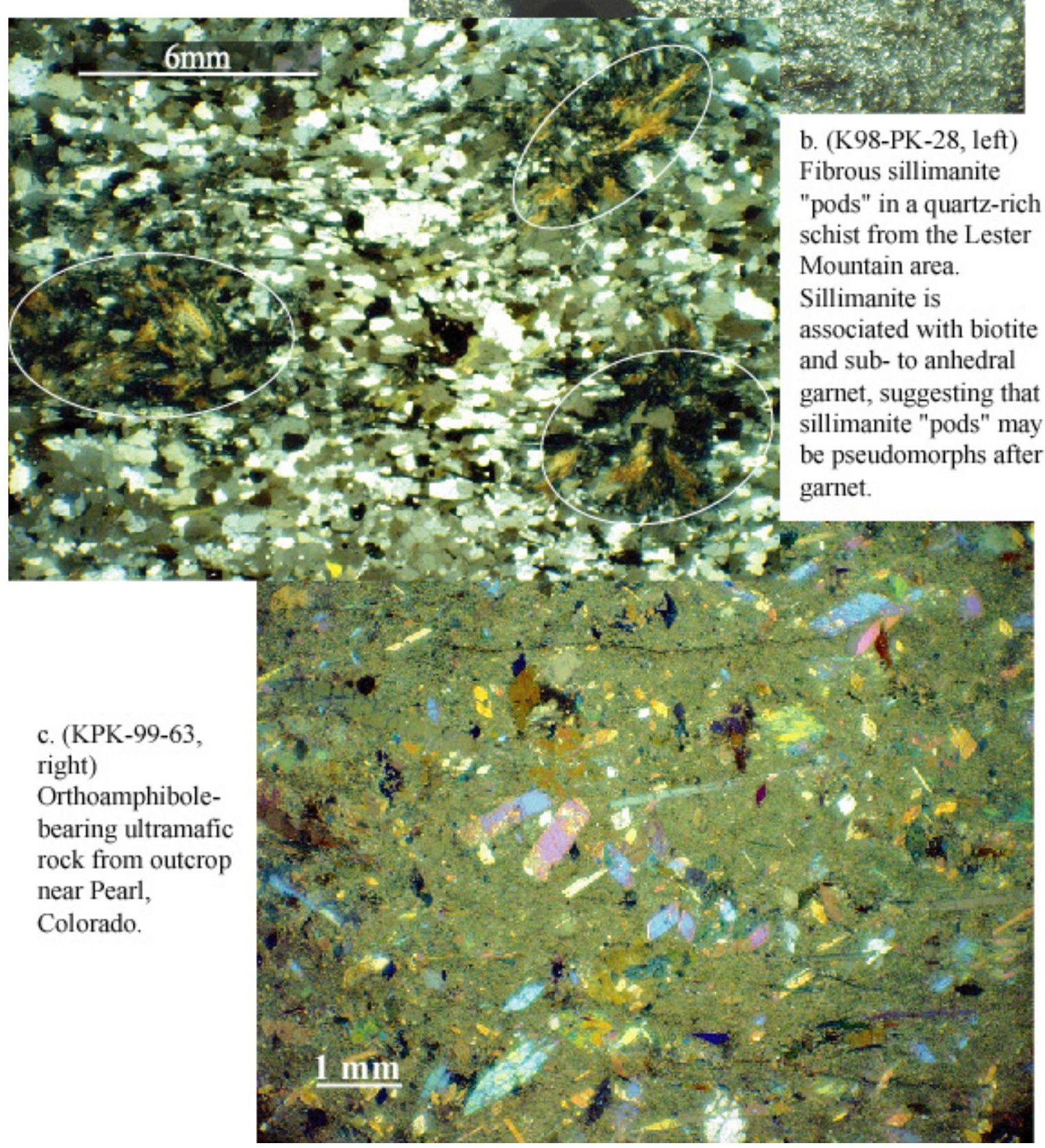


analyses of detrital zircon suites in the quartzite yielded $\mathrm{Pb}-\mathrm{Pb}$ ages of $2034 \mathrm{Ma}$ and 1778 Ma (Aleinikoff et al., 1993). A U-Pb zircon from a metarhyolitic unit in Willow Creek Canyon southeast of Lester Mountain yields a date of ca. $1760 \mathrm{Ma}$ (Chamberlain, unpublished data), 20 m.y. younger than the ca. 1780 Ma age of Green Mountain metavolcanic rocks. These data suggest that the quartzite-pelite assemblage was deposited on top of the Green Mountain terrane and then deformed with it during later progressive tectonism. It may be part of an accretionary complex, as depicted in our tectonic model, or a post-tectonic successor basin.

\section{$\underline{\text { Mica Basin }}$}

In the $2 \times 3-\mathrm{km}$ Mica Basin area to the east, the Elkhorn Mountain/Seven Lakes commingled diabasic gabbro and fine-grained granite are in intrusive contact with migmatized, metamorphosed bimodal volcanic rocks interlayered with aluminous, sillimanite-pod-bearing schists (Appendix D, Figure 5a). The bimodal metavolcanic rocks have abundant felsic material, a low $\mathrm{La} / \mathrm{Nb}$ ratio and a high $\mathrm{Ba} / \mathrm{La}$ ratio, all consistent with but not diagnostic of a rift setting (Foster et al., 1999). One possibility consistent with this geochemistry is that these rocks formed during back-arc spreading or some other extensional setting within the arc complex.

Slivers of "exotic" rock types outcrop in a northeast-trending pattern, together defining the Farwell Mountain-Lester Mountain suture zone (Appendix B, Plate 1a). Lenses of marble with amphibolite (Figure 2a), calcsilicate, and metachert were interpreted by Rougvie and Carlson (1997) as altered marine exhalites. Feldspathic nodular sillimanite gneiss - called "siliceous pod rock" by Snyder (1988) - is found in 


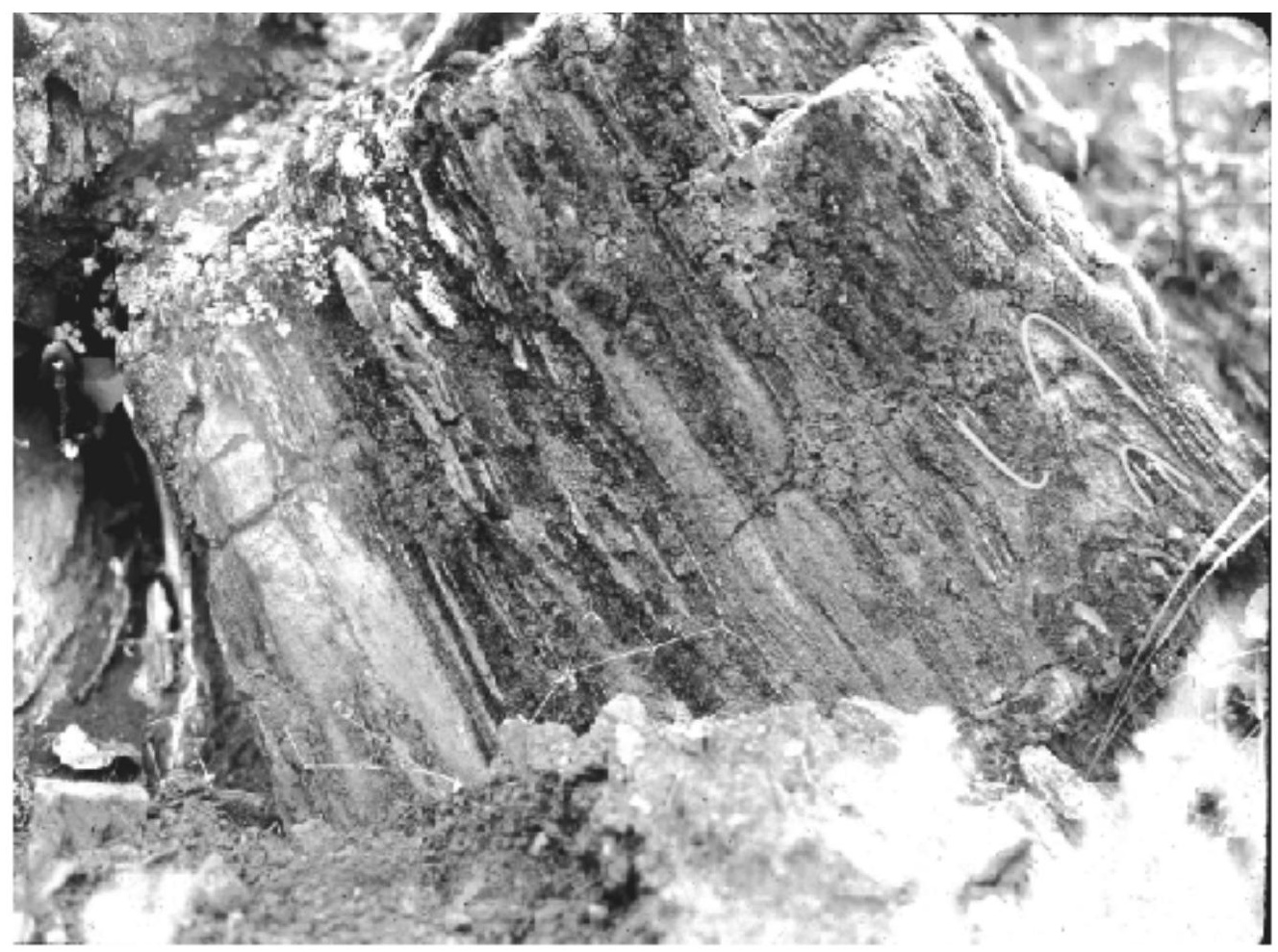

Figure 2. Field photographs of "exotic" lithologic types in the Farwell Mountain -- Lester Mountain suture zone. a. (above) Interlayered marble and calc-silicate rock (Xm) east of Lester Mountain. Note "F2" folds of compositional layering. b. (below) Deformed basalt pillow rind found among amphibolite and metavolcanic gneiss south of Farwell Mountain, on the east side of the ridge along Forest Rte. 431. Lens cap for scale.

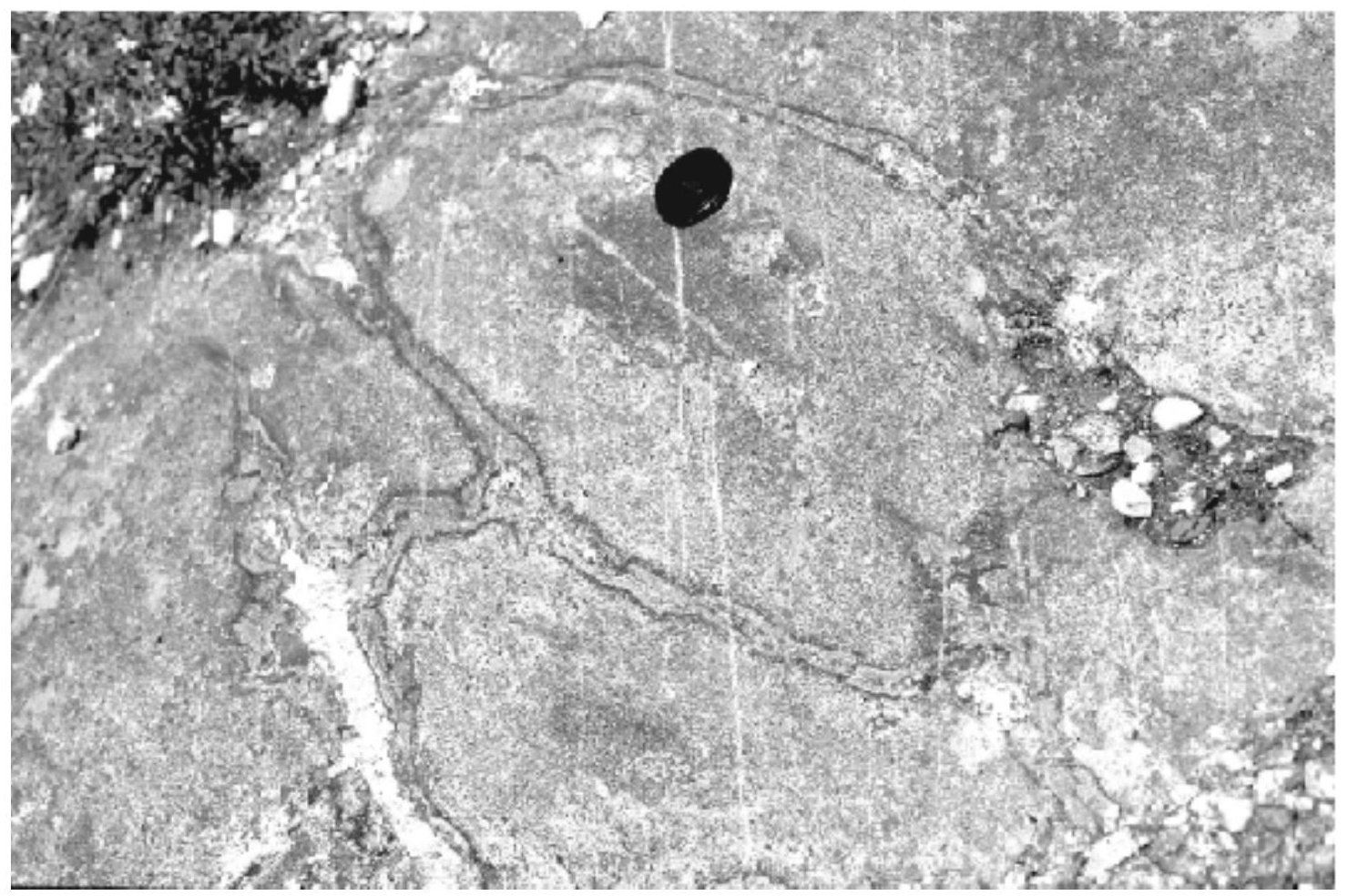


metavolcanic schists that are commonly tectonically interlayered with marble. "Pod rock" is characterized by a darker-colored matrix of quartz + feldspar + micas surrounding lighter-colored "pods" of quartz + sillimanite \pm muscovite (Figure $1 \mathrm{~b})$. Pods range in size $(<1 \mathrm{~mm}$ to $16 \mathrm{~cm})$ and distribution from outcrop to outcrop, comprising up to $25 \%$ of the rock (Snyder, 1988). The textural relationship between pods and matrix is enigmatic: the margins are gradational on thin-section scale and pods have no clearly consistent orientation with respect to structural fabrics (Snyder, 1988). Abundant "pods" have been mapped in a felsic gneiss south of Lester Mountain in Willow Creek Canyon, interlayered with gneisses $\sim 1 \mathrm{~km}$ southeast of Farwell Mountain, mingled with migmatitic gneisses in Mica Basin, and in schists at the northeast end of the Farwell Mountain-Lester Mountain suture zone near Pearl. Like previous workers, we are unsure what the pod rock represents. One possibility is that the pods formed in schists and gneisses which underwent (post-accretion) hydrothermal alteration because of their location along an accretion-related structural boundary where fluids were channelized during a subsequent heating event. This is consistent with the spatial association between pod rock and deformed pillow basalts and marbles in a northeast-trending belt within the Farwell Mountain - Lester Mountain zone. The protoliths of the pod rocks are probably mixed sedimentary and volcanic rocks; we speculate that they may have been part of an accretionary prism to the south of the Green Mountain block.

Snyder $(1978,1980)$ identified a variety of mafic and ultramafic intrusive bodies (tens to hundreds of feet in diameter) as chromite- or spinel-bearing amphibole peridotites, orthoamphibole-rich rocks, dunite, wehrlite, and harzburgite; most are partially altered to amphibolite (e.g. Figure 1c) Snyder, 1978, 1980). Ultramafic bodies in 
and near the gabbro show neither gradation in composition at their margins nor signs of crystal settling (Snyder, 1988). Metamorphosed, deformed pillow basalts (Figure 2b) have also been observed $\sim 2 \mathrm{~km}$ southeast of Farwell Mountain within the proposed suture zone.

In summary, the Farwell Mountain-Lester Mountain zone potentially contains all the lithologic components of an ophiolite suite. As discussed in the Introduction, ophiolites on continents are often interpreted as indicators of sutures. Also, the singularity of the Lester Mountain metasedimentary package among Park Range exposures may imply that its preservation is due to its location in a suture zone between the crust of the Green Mountain and Rawah blocks. The northeast-trending belt appears to represent a broad, high-grade zone with elusive boundaries that has been much altered by progressive tectonism. Despite this complexity, lithologic evidence is consistent with the hypothesis that the Farwell Mountain - Lester Mountain zone consists of imbricated tectonic slivers of both the Green Mountain and Rawah blocks, possibly separated by remnants of an accretionary complex. The other lines of evidence used to generate and test this hypothesis are presented below and in appendices B-G.

\section{THE RAWAH BLOCK.}

In the Rawah block to the south of the proposed suture zone, supracrustal rocks $(<1.76 \mathrm{Ga})$ and granites $(<1.75 \mathrm{Ga})$ are younger than rocks to the north. The $1746 \pm 6 \mathrm{Ma}$ Buffalo Pass pluton (Premo and Van Schmus, 1989; quartz monzonite, granodiorite augen gneiss, and equigranular quartz monzonite gneiss) in this zone is thought to be the northernmost sliver of a 1.75-1.72 Ga granitic batholith that includes the $1735 \pm 8$ Rabbit 
Ears Pass quartz diorite (Snyder 1988, 1980; Tweto, 1976) and to the east as the $1720 \pm 8$ (Premo and Van Schmus, 1989) Rawah batholith quartz monzonite in the Front Range. These age differences, however, are subtle and more geochronologic and geochemical work are necessary to better define the fine discontinuities.

\section{Mt. Ethel pluton.}

The ca. 1.42 Ga Mount Ethel pluton lies on the northern edge of the Soda Creek Fish Creek shear zone and is cut by mylonitic shear bands at its margin. The main pluton is largely undeformed and consists of several phases ranging from diorite and granodiorite to quartz monzonite. The two main phases of the Mount Ethel pluton, the Rocky Peak quartz monzonite porphyry and the Roxy Ann Lake granite and quartz monzonite, have whole-rock geochemistry similar to "A-type" granites (Barinek et al., 1999; Frost and Frost, 1997). Major element analysis of these phases shows a similarity to the Sherman Granite (Snyder, 1978; Edwards, 1993 as reported in Frost and Frost, 1997). Although Snyder et al. (1988) hypothesized that the Mount Ethel pluton was the result of a post-subduction event involving lower continental crustal melting, Barinek et al. (1999) suggested that its similarity to the Sherman Granite and large range in $\mathrm{SiO}_{2}$ content is more consistent with a mixed crust and mantle source (Frost and Frost, 1997).

\section{$\underline{\text { Soda Creek - Fish Creek shear zone }}$}

The Soda Creek-Fish Creek shear zone is a 6-km-wide, subvertical, northeasttrending ductile high strain zone overprinted by anastomosing mylonite strands: evidence 
for a history of multiple movements (Barinek et al., 1999). Based on these characteristics, the shear zone was highlighted as a second potential Paleoproterozoic suture by Foster et al. (1999). The country rock to the Mount Ethel pluton in the shear zone consists of the highly sheared, multiply-deformed 1746 Ma Buffalo Pass pluton and migmatized metavolcanic, metaigneous, and possibly metasedimentary gneisses and schists. Despite our inability to evaluate the prominence of the shear zone on the basis of seismic reflection data (assuming it continues as a subvertical feature at depth) it remains possible that the shear zone was related to the progressive development of the suture. It may have been either a shallowly-dipping continuation of the broad suture zone, and/or a transcurrent or transpressional boundary accommodating strains during progressive tectonism. The strong overprinting of the shear zone by events at ca. $1.68 \mathrm{Ga}$ and ca. 1.42

Ga (including the intrusion of the Mount Ethel pluton) has largely blurred the evidence of the earliest fabrics and could also be responsible for steepening the zone, if it was originally shallower.

\section{PHANEROZOIC GEOLOGY OF THE PARK RANGE.}

Permian through Miocene flat-lying to shallowly dipping strata lie directly above the Great Unconformity in the Park Range, indicating that this region was a topographic high in the Upper Paleozoic, likely related to the Ancestral Rockies.

Paleozoic and Mesozoic strata are juxtaposed against Precambrian rocks along east-west and north-south-trending faults that are inferred to have been active during the Cretaceous-Tertiary Laramide orogeny. It is important to take these faults into account because they form the boundaries of the Paleoproterozoic exposures. We infer that they 
are narrow zones of reverse faulting with modest displacement (at a crustal scale) and hence have restored them for the geologic cross section along the seismic transect (Appendix B, Plate 2). The net vertical offset on these faults is $<1-2 \mathrm{~km}$ (inferred from map relations).

This area is essentially the northernmost extent of the Rio Grande rift; the Browns Park Formation is correlative with the Santa Fe Group and records a modest amount of Miocene extension. Some Tertiary volcanic activity has penetrated low-lying areas in the Park Range, e.g. Hahn's Peak and Rabbit Ears Pass. Minor normal-sense offsets of some of the Miocene volcanic and volcaniclastic deposits have occurred along east-west and north-south-trending brittle faults, many of which also have earlier Laramide displacement histories. Quaternary glacial and alluvial deposits cover much of the area.

In general, the key field areas appear to have been relatively unaffected by Phanerozoic activity. One possible exception is a high-angle, east-west-trending fault with evidence for Laramide and Tertiary slip (Snyder, 1980), which separates the Farwell Mountain and Lester Mountain uplifts. This structure may have contributed to the metamorphic contrast between the two areas by juxtaposing blocks that were at different depths by the end of the Proterozoic orogeny. However, the net vertical offset $(<1-2 \mathrm{~km}$ since the Mesozoic, based on field relations) does not seem adequate to account for the observed range in pressures and temperatures recorded in the exposed rocks. It remains unknown whether there was a strike-slip component to the Laramide and/or Tertiary slip or whether the basement was offset by this fault prior to the deposition of the Upper Paleozoic units it offsets. Still, Phanerozoic faulting appears to have been a small 
component of the deformation history in the field area and explains neither the metamorphic contrast nor the reflectivity structure of the region.

\section{METAMORPHISM: DISCONTINUITY ACROSS THE FARWELL MOUNTAIN-} LESTER MOUNTAIN SUTURE ZONE.

Several workers have investigated the pressure-temperature history of Proterozoic metamorphic rocks in the Farwell Mountain and Lester Mountain areas. Foster et al. (1999) tentatively identified a metamorphic break between greenschist facies at Farwell Mountain and upper amphibolite facies at Lester Mountain and other exposures to the south and east of the "Farwell Mountain - Lester Mountain suture zone". The following sections present existing pressure-temperature data for the Farwell Mountain, Mica Basin, Lester Mountain, and Soda Creek-Fish Creek shear zone rocks from north to south. As a summary, pressure-temperature (P-T) paths for all four subareas are shown in Figure 3. Constraints on these paths are discussed for each subarea below.

\section{FARWELL MOUNTAIN}

Garnet-chlorite-chloritoid assemblages place the Farwell Mountain supracrustal package in the greenschist facies (Smith, 1990; Foster et al., 1999). No sillimanite has been identified, and garnets are limited to small sizes. Smith (1990) used garnet-biotite thermometry in garnet-bearing metasedimentary rocks from Farwell Mountain to contrain maximum temperature conditions. Due to the lack of an adequate assemblage for barometry, the thermometer was solved at 3 and 7 kbar to bracket middle-crustal depths. Average temperature at $3 \mathrm{kbar}$ was $\sim 490^{\circ} \mathrm{C}$ and at $7 \mathrm{kbar}$ was $\sim 500^{\circ} \mathrm{C}$ (Smith, 1990). 


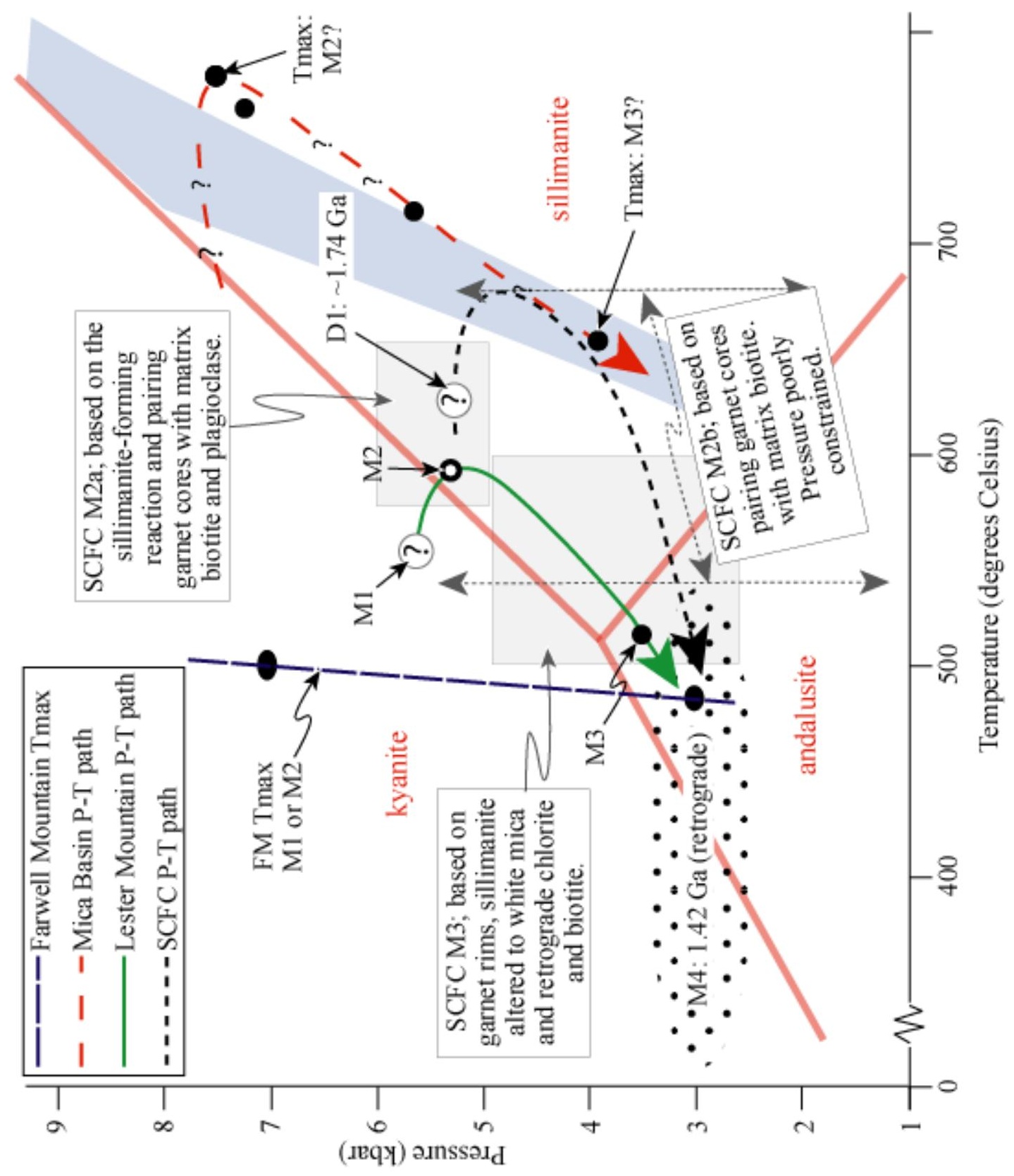

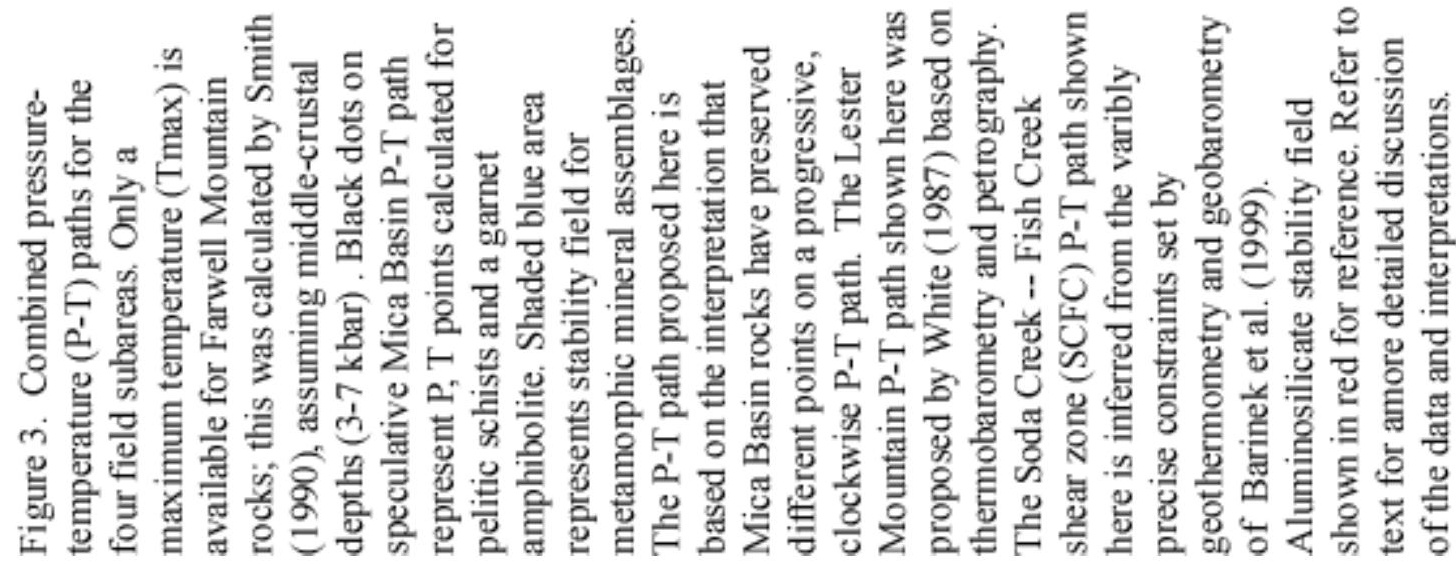


These results are consistent with the mineral assemblages; thus, the constraint placed here on the maximum temperature of the Farwell Mountain area is considered to be a relatively solid one.

MiCA BASIN

Maximum temperatures (Tmax) and pressures (at Tmax) were calculated by Kennedy (1992) for garnet biotite sillimanite gneisses and a garnet-amphibolite in Mica Basin. Garnet-biotite thermometry and GASP barometry yielded the following results for three pelitic rock samples: $720^{\circ} \mathrm{C}, 5.7 \mathrm{kbar} ; 655^{\circ} \mathrm{C}, 3.9 \mathrm{kbar}$; and $780^{\circ} \mathrm{C}, 7.5 \mathrm{kbar}$ (Kennedy, 1992). A garnet amphibolite yielded a Tmax and pressure (at Tmax) of 750$770^{\circ} \mathrm{C}, \sim 7.5 \mathrm{kbar}$, based on both the garnet-hornblende and garnet biotite thermometers and the garnet-hornblende-plagioclase barometer. Mineral assemblages place Mica Basin rocks in the sillimanite + biotite + garnet + muscovite + quartz stability field or in the potassium feldspar aluminosilicate zone (Figure 3; Kennedy, 1992; Spear and Cheney, 1989).

The wide range in these pressure-temperature $(\mathrm{P}-\mathrm{T})$ data over a geographically small region may be due to an over-correction for non-ideal behavior giving artificially high temperatures (Kennedy, 1992). However, the temperatures were confirmed by two geothermometers and are consistent with the assemblages, abundant melt pods, and gneissic fabric of the Mica Basin area. It is possible that the pelitic rocks are recording different points along the P-T path through time; this is the hypothesis presented schematically in Figure 3. If so, these results are indicative of a clockwise P-T path 
characterized by decompression from $\sim 7.5$ to $\sim 4 \mathrm{kbar}$, roughly equivalent to $12 \mathrm{~km}$ of unroofing while these rocks were in the middle crust ( 10-25 km depths).

\section{LESTER MOUNTAIN}

Sillimanite, staurolite, and kyanite are present in metamorphic mineral assemblages at Lester Mountain. White (1987) assigned Lester Mountain rocks to amphibolite grade and divided the area into two metamorphic zones based on assemblages and reaction textures. White (1987) calculated thermobarometry for samples from each zone.

1) The staurolite-sillimanite zone on the south side contains the assemblage staurolite + sillimanite + muscovite + biotite + quartz and is a result of the reaction (White, 1987): muscovite + chlorite + staurolite + quartz $=$ biotite $+\mathrm{Al}_{2} \mathrm{SiO}_{5}+\mathrm{H}_{2} \mathrm{O}$. It is bounded to the north by the staurolite-out isograd: muscovite + staurolite + quartz $=$ biotite + $\mathbf{A l}_{2} \mathrm{SiO}_{5}+$ garnet $+\mathbf{H}_{2} \mathbf{O}$. White (1987) attributed the abundance of sillimanite and scarcity of kyanite in this zone mainly to differences in initial bulk composition or water fugacity that caused the $\mathrm{Al}_{2} \mathrm{SiO}_{5}$ - producing reaction to occur at different temperatures in different rocks. Average thermobarometric results for this zone were $\sim 575^{\circ} \mathrm{C}, 5.2 \mathrm{kbar}$ (White, 1987).

2) The sillimanite zone north of the staurolite-out isograd contains the assemblage muscovite + quartz $+\mathrm{Al}_{2} \mathrm{SiO}_{5}+$ biotite + garnet, a result of staurolite breakdown (White, 1987). Essentially all aluminum silicate in this zone is sillimanite, generally occurring as fibrolite with crystals crosscutting foliation and nodules aligned in the foliation plane. Average thermobarometric results for this zone were $\sim 600^{\circ} \mathrm{C}, 5.4 \mathrm{kbar}$ (White, 1987). 
White (1987) presented a clockwise P-T history for Lester Mountain consisting of (1) an early, medium-pressure event $\sim 550^{\circ} \mathrm{C},>5.3$ kbar during which kyanite grew, making this one of the few kyanite locations in Colorado; (2) peak metamorphic conditions of $\sim 600^{\circ} \mathrm{C}, 5.3 \mathrm{kbar}$; and (3) a late, slightly cooler rehydration event at $\sim 500^{\circ} \mathrm{C}, 3.5 \mathrm{kbar}$, based on resetting of the garnet-biotite thermometer and GASP barometer. The extent and quality of thermobarometric and petrographic work in the Lester Mountain area, the agreement between metamorphic mineral assemblages and calculated P-T points, and the consistency of the fabric sequence throughout the subarea all suggest that this P-T path is fairly well established.

\section{Ca.1.4 Ga-Mount Ethel Pluton And Soda CreeK - Fish Creek Shear Zone}

Two generations of garnet were identified in country rock bearing the assemblage garnet + biotite + plagioclase + muscovite \pm sillimanite near the Mount Ethel pluton (Barinek et al., 1999). The first garnet generation (“ $\mathrm{M}_{2 \mathrm{a}}$ ") was deemed syntectonic with $\mathrm{S}_{1}$; the second $\left(\mathrm{M}_{2 \mathrm{~b}}\right)$ post-tectonic relative to the dominant, northeast-striking foliation in the Soda Creek-Fish Creek shear zone (Barinek et al., 1999). Table 2 shows the relationships between deformational and metamorphic fabrics in the shear zone based on available geochronologic data (Table 1).

Thermobarometric calculations were performed for sillimanite-garnet-biotite schist, muscovite-garnet-biotite schist, biotite-garnet gneiss, and garnet-amphibolite from the Soda Creek-Fish Creek shear zone in the vicinity of the Mount Ethel pluton. $\mathrm{M}_{1}$ and $\mathrm{M}_{2}$ garnet cores were coupled with biotite and plagioclase in the matrix. $\mathrm{M}_{1}$ yielded conditions of $>600^{\circ} \mathrm{C}, \sim 5$ kbar independent of sample proximity to the pluton. $\mathrm{M}_{2}$ results 
Table 1. U-Pb and Th-U-Pb Geochronology in Park Range and northern Gore Range (From NSF proposal by Foster, C.T., Chamberlain, K., Karlstrom, K.E.)

\begin{tabular}{|c|c|c|c|}
\hline Unit & Age (Ma) & type & Reference \\
\hline \multicolumn{4}{|c|}{ Green Mountain Arc (representative dates): } \\
\hline Rhyolite porphyry & $1780 \pm 6$ & U-Pb zircon & Premo and VanSchmus (1989) \\
\hline Encampment River granodiorite & $1779 \pm 5$ & $\mathrm{U}-\mathrm{Pb}$ zircon & Premo and VanSchmus (1989) \\
\hline Sierra Madre granite & $1763 \pm 6$ & $\mathrm{U}-\mathrm{Pb}$ zircon & Premo and VanSchmus (1989) \\
\hline \multicolumn{4}{|c|}{ Park Range-between Green Mtn \& SC-FC sz (all dates): } \\
\hline Elkhorn Mt gabbro-qtz diorite & $1774 \pm 2$ & $\mathrm{U}-\mathrm{Pb}$ zircon & Pallister and Aleinikoff (1987) \\
\hline Elkhorn Mt gabbro-qtz monz. & $1769 \pm 6$ & $\mathrm{U}-\mathrm{Pb}$ zircon & Pallister and Aleinikoff (1987) \\
\hline Elkhorn Mt gabbro-gt gneiss & $1768 \pm 8$ & $\mathrm{U}-\mathrm{Pb}$ zircon & Pallister and Aleinikoff (1987) \\
\hline Seven Lakes granodiorite & $1769 \pm 8$ & $\mathrm{U}-\mathrm{Pb}$ zircon & Pallister and Aleinikoff (1987) \\
\hline White quartz monzonite & $1627 \pm 4$ & $\mathrm{U}-\mathrm{Pb}$ zircon & Premo and VanSchmus (1989) \\
\hline \multicolumn{4}{|l|}{ SC-FC sz: (all dates) } \\
\hline deformed pegmatite & $1765 \pm 8$ & U-Pb zircon & Premo and VanSchmus (1989) \\
\hline deformed Buffalo Pass pluton & $1746 \pm 6$ & $\mathrm{U}-\mathrm{Pb}$ zircon & Premo and VanSchmus (1989) \\
\hline pegmatite that cuts early S1 foliation & 1740 & $\mathrm{U}-\mathrm{Pb}$ zircon & Chamberlain (unpub); prelim. age \\
\hline aplite with late $\mathrm{S} 1$ foliation & 1730 & $\mathrm{U}-\mathrm{Pb}$ zircon & Chamberlain (unpub); prelim. age \\
\hline hornblende pegmatite that cuts S2 & 1680 & $\mathrm{U}-\mathrm{Pb}$ zircon & Chamberlain (unpub); prelim. age \\
\hline M1 sphene (dark) & 1680 & $\mathrm{U}-\mathrm{Pb}$ sphene & Chamberlain (unpub); prelim. age \\
\hline M2 sphene (pale) & 1600 & U-Pb sphene & Chamberlain (unpub); prelim. age \\
\hline M1 monazite in Sil-G-Ms schist & $1682 \pm 19^{*}$ & Th-U-Pb monazite & Foster (unpub.) microprobe date \\
\hline M2 monazite in Sil-G-Ms schist & $1610 \pm 22^{*}$ & Th-U-Pb monazite & Foster (unpub.) microprobe date \\
\hline \multicolumn{4}{|l|}{ Park Range-S of SC-FC sz: (all samples) } \\
\hline Sill-G.-Ksp gneiss 5 miles S of SCFCSZ & $1745 \pm 17^{*}$ & Th-U-Pb monazite & Foster (unpub.) microprobe date \\
\hline Rabbit Ears Pass qtz diorite & $1735 \pm 8$ & $\mathrm{U}-\mathrm{Pb}$ zircon & Premo and VanSchmus (1989) \\
\hline \multicolumn{4}{|c|}{ Gore Range-11 mi. SW of Kremmling: (all dates) } \\
\hline Sill-Gar-gneiss & $1697 \pm 34^{*}$ & Th-U-Pb monazite & Foster (unpub.) microprobe date \\
\hline Feldsp-Biot-Gar-gneiss & $1665 \pm 38^{* *}$ & Th-U-Pb monazite & Foster (unpub.) microprobe date \\
\hline
\end{tabular}

indicated a temperature gradient suggestive of a contact aureole from $\sim 680^{\circ} \mathrm{C}$ within 1

$\mathrm{km}$ of the pluton to $\sim 540^{\circ} \mathrm{C} 5 \mathrm{~km}$ to the south (Barinek et al., 1999). However, it is

important to note that it is extremely difficult to reliably correlate garnet cores with

matrix biotite grains. The procedure is based on the large assumption that matrix biotites

grew synchronously with garnet cores and that matrix biotite compositions have not been

subsequently modified. It is also based on the more realistic assumption that the garnet

core compositions have not been altered by diffusion.

Rims of $\mathrm{M}_{1}$ and $\mathrm{M}_{2}$ garnets matched at $\sim 550 \pm 50^{\circ} \mathrm{C}$, independent of sample

location. Rocks that appear to have been exposed to post- $\mathrm{M}_{2}$ rehydration show textural

evidence of sillimanite altering to white mica or garnet altering to retrograde biotite and 
Table 2. Correlation of deformational and metamorphic fabrics in the Soda Creek - Fish Creek shear zone based on geochronology (Table 1) and field and petrographic relationships.

\begin{tabular}{|c|c|c|}
\hline FOLIATION GENERATION & METAMORPHIC EVENT & U-PB AGES \\
\hline $\begin{array}{l}\mathrm{S}_{0} \text { (bedding in meta- } \\
\text { sedimentary, volcanic, } \\
\text { volcaniclastic rocks) }\end{array}$ & --- & $\begin{array}{l}\text { Pre-1.746 Ga (age of } \\
\text { Buffalo Pass granite) }\end{array}$ \\
\hline $\begin{array}{l}\mathrm{S}_{1} \text { (first tectonic layering in } \\
\text { Buffalo Pass granite) }\end{array}$ & $\begin{array}{l}\mathrm{M}_{1} ? \text { (Possible time of } \\
\text { kyanite growth) }\end{array}$ & $\begin{array}{l}\sim 1.746-1.73 \text { Ga (age of } \\
\text { Rabbit Ears Pass quartz } \\
\text { diorite and Buffalo Pass } \\
\text { granite, and late-syn-S1 } \\
\text { aplite dike) }\end{array}$ \\
\hline $\begin{array}{l}\mathrm{S}_{2}\left[=\text { Regional } \mathrm{S}_{3},\right. \\
\text { Appendix D (folding and } \\
\text { transposition into northeast- } \\
\text { trending, subvertical } \\
\text { foliation)] }\end{array}$ & $\begin{array}{l}\mathrm{M}_{2 \mathrm{a}}(\text { sillimanite fabrics } \\
\text { overprint } \mathrm{S}_{1}, 1^{\text {st }} \text { garnet } \\
\text { generation in Soda Creek- } \\
\text { Fish Creek shear zone) }\end{array}$ & $\begin{array}{l}1.68 \mathrm{Ga} \text { (dark sphene) } \\
1.68 \mathrm{Ga} \text { (syn- } \mathrm{S}_{2} \text { hbl- } \\
\text { pegmatite dike) } \\
1682 \pm 19 \mathrm{Ma} \text { (Th-U-Pb } \\
\text { monazite) }\end{array}$ \\
\hline $\begin{array}{l}\text { Continued residence in } \\
\text { middle crust, heating and/or } \\
\text { fluid flux. Possible } \\
\text { tightening/steepening of } \mathrm{S}_{2} \\
\text { fabric }\end{array}$ & $\begin{array}{l}\mathrm{M}_{2 \mathrm{~b}}\left(2^{\text {nd }} \text { garnet generation }\right. \\
\text { in Soda Creek-Fish Creek } \\
\text { shear zone })\end{array}$ & $\begin{array}{l}1.60 \mathrm{Ga} \text { (pale sphene) } \\
1610 \pm 22 \mathrm{Ma}(\mathrm{Th}-\mathrm{U}-\mathrm{Pb} \\
\text { monazite) }\end{array}$ \\
\hline $\begin{array}{l}\mathrm{S}_{3}\left[=\text { Regional } \mathrm{S}_{4} \text {, }\right. \\
\text { Appendix D (mylonitic } \\
\text { shear, semi-brittle faults } \\
\text { with pseudotachylyte shear } \\
\text { bands)] }\end{array}$ & $\begin{array}{l}\mathrm{M}_{3} \text { (garnet rim growth, } \\
\text { retrograde metamorphism: } \\
\text { chloritization, possible } \\
\text { major fluid flux) }\end{array}$ & $\begin{array}{l}\sim 1.42 \mathrm{Ga} \text { (based on age of } \\
\text { Mount Ethel pluton) }\end{array}$ \\
\hline
\end{tabular}

chlorite. These textures may record either an $\mathrm{M}_{3}$ event or reequilibration during prolonged post- $\mathrm{M}_{2}$ high temperature conditions (Barinek et al., 1999).

These results are in agreement with ${ }^{40} \mathrm{Ar}-{ }^{39} \mathrm{Ar}$ data (see Appendix E) that show ca. $1.4 \mathrm{Ga}$ temperatures of $>500^{\circ} \mathrm{C}$ near the pluton, but dropping off to $<500^{\circ} \mathrm{C}$ to the south (Colin Shaw, personal communication, 2001).

In summary, the lithologic, geochronologic, and metamorphic data collected prior to this study are all consistent with the presence of a major structural boundary in the 
northern Park Range, possibly localized between the Farwell Mountain and Lester Mountain areas. 


\section{APPENDIX B. FIELD MAPS AND GEOLOGIC CROSS SECTION}

The major data-collecting periods for this study were during the summer field seasons of 2000 and 2001. Because the 1:48,000 scale geologic maps of the Park Range by Snyder (1980; see Plate 1a) are of excellent quality and contain a high level of detail, it was possible to direct field questions based on hypotheses generated from the existing maps. I and my field assistants completed detailed 1:6,000 and 1:12,000 scale geologic maps for parts of the field area that are of particular interest to the exploration of the "Farwell Mountain - Lester Mountain suture zone".

The Lester Mountain area was chosen for detailed study due to its location south of the metamorphic break described by Foster et al. (1999) and the presence of a quartzite-schist package that has preserved multiple deformational and metamorphic fabrics. My map at 1:12,000 scale of Lester Mountain (Plate 1c) and the surrounding area shows in detail the multiple fabrics and tectonic imbrication that characterize this zone. The inset cross section for the Lester Mountain area shows an inferred duplex geometry representing thrust imbrication of tectonic slivers to explain the outcrop pattern.

The Mica Basin area has a mysteriously round map pattern on Snyder's (1980) map and Kennedy (1992) proposed that its "swirling" fabrics and closed folds were due to a vortex created at the margin of the intruding Seven Lakes granodiorite. My 1:12,000 scale map of Mica Basin (Plate 1b) is a compilation of Snyder's (1980) map and new field data; newly observed field relations and measurements show that the map patterns 
can be explained as interference patterns due to the overprinting of several generations of deformation.

My overall geologic interpretation of the region is shown in a 1:48,000 scale north-south geologic cross section (Plate 2) with insets for the Lester Mountain and Mica Basin areas that combines my detailed maps with the maps by Snyder (1980) in the Park Range and is extended into the Sierra Madre, Wyoming based on the map of Houston and Graff (1995). The cross section line coincides with the CD-ROM Cheyenne belt seismic line; these and the sections that were projected into the cross section line are shown (in red) on Plate 1a. The tectonic interpretation of the combined section is discussed in the main text and in Appendix G. 


\section{APPENDIX C. SAMPLE LOCATION MAPS AND SAMPLE LISTS}

Oriented samples were collected whenever possible during field research. Table 1 lists samples collected during the 2000-2001 field seasons. Table 2 lists samples collected by Karl Karlstrom during reconnaissance trips 1998-1999. Many of the samples in these two tables were cut for thin sections; their petrography and microstructure are discussed in Appendix D. Sample locations are labeled on the following maps by station number (Tables 1, 2): Farwell Mountain area - Plate 3, near Pearl, Colorado - Plate 4, Mica Basin area - Plate 5, Lester Mountain area - Plate 6, Soda Creek - Fish Creek shear zone - Plate 7.

Geochronologic data for this field area are largely the result of the work of Kevin Chamberlain at University of Wyoming. Table 3 lists samples collected by or sent to Kevin Chamberlain for U-Pb zircon or metamorphic sphene dating; the results are in Appendix A, Table 1). 
Table 1. Samples collected during field seasons 2000-2001 listed by map area. Refer to Appendix D, Table 1 for thin section descriptions of samples marked by asterix. Q---quartz; gar---garnet; sill---sillimanite; plag---plagioclase feldspar; bio---biotite; st---staurolite; hbl---hornblende

\begin{tabular}{|c|c|c|c|c|c|}
\hline Sample ID & Station No. & Lithology/Location & $\mathbf{S}$ & $\mathbf{L}$ & $\mathbf{A}$ \\
\hline \multicolumn{6}{|c|}{ Farwell Mountain area } \\
\hline *AT-01-FM-1 & AT-01-FM-1 & marbley amphibolite w/gar (near pillow basalts) & $340,74 \mathrm{~W}$ & & \\
\hline AT-01-FM-2 & AT-01-FM-2 & big sill pods south of Farwell Mountain & $085,89 \mathrm{~S}$ & & \\
\hline FM-00-01 & F1 & $\begin{array}{l}\text { volcanic agglomerate (Xca) - clasts of plag- } \\
\text { porphyritic andesite in dacite matrix }\end{array}$ & $317,64 \mathrm{NE}$ & $64-->066$ & \\
\hline FM-00-02 & $\mathrm{F} 1$ & Xca float - w/garnets and biotite & - & & \\
\hline FM-00-03 & $\mathrm{F} 2$ & Xca turbidites(?) - garnet & $\begin{array}{c}320,89 \mathrm{NE}(\mathrm{S} 2, \text { transects } \\
\mathrm{F} 1 \mathrm{~s})\end{array}$ & & $\begin{array}{c}\text { nearby } \\
271,69 \mathrm{~N} \\
(\mathrm{~F} 1)\end{array}$ \\
\hline FM-00-04 & $\mathrm{F} 2$ & cordierite in Xca turbidites aligned in S2 & $\begin{array}{l}\text { fracture } 325,85 \mathrm{E} ; \mathrm{S} 2 \\
282,75 \mathrm{~N}\end{array}$ & & \\
\hline \multicolumn{6}{|l|}{ Mica Basin area } \\
\hline *AT-01-M1 & M1 & gar-amphibolite & $\begin{array}{l}\text { 088, } 76 \mathrm{~S} \text { (Sample } \\
\text { surface) }\end{array}$ & & \\
\hline AT-01-M3 & M3 & pegmatite w/parasitic folds & & & \\
\hline AT-01-M4A & M4 & ultramafic & & & \\
\hline AT-01-M4B & M4 & ultramafic & & & \\
\hline AT-01-M7 & M5-8 & Xep ultramafic & $038,86 \mathrm{~W}$ & RAKE $70 \mathrm{~N}$ & \\
\hline AT-01-M8 & M5-8 & Tectonized Xep/Xgn & $025,86 \mathrm{~W}$ & $85-->300$ & \\
\hline AT-01-M9B & M9-13 & Xs fold/crenulation & $040,80 \mathrm{~W}$ & & \\
\hline *AT-01-M11 & M9-13 & Xs w/pods, crenulation & $\sim \mathrm{S} 3: 082,75 \mathrm{~S}$ & & \\
\hline *AT-01-M12 & M9-13 & lovely folds (cm-scale) mafic gneiss & 025, 85E (Fold env) & & \\
\hline *K01-MB-1 & \multirow{4}{*}{$\begin{array}{l}\text { "K01-MB-1-4; outcrop } \\
\text { @ jet of Mica Basin \& } \\
\text { Gilpin Lake Trails }\end{array}$} & amphibolitic gabbro & \multirow{4}{*}{\multicolumn{3}{|c|}{ not oriented }} \\
\hline *K01-MB-2 & & grey dioritic-granodioritic gneiss & & & \\
\hline *K01-MB-3 & & syn-D2 granitoid & & & \\
\hline *K01-MB-4 & & crosscutting pegmatite dikes & & & \\
\hline
\end{tabular}


Table 1, Mica Basin area, continued.

\begin{tabular}{|c|c|c|c|c|}
\hline *K01-MB-5 & M9-13 & gabbroic pegmatite (?) & $000,68 \mathrm{~N}$ & \\
\hline *K01-MB-7 & M9-13 & sillimanite-bearing gneiss & $075,26 \mathrm{SE}$ & \\
\hline *K01-MB-8 & M9-13 & migmatite & 010,90 & \\
\hline *K01-MB-9 & M9-13 & sillimanite-mica schist & $350,56 \mathrm{~W}$ & \\
\hline *K01-MB-10 & M9-13 & ultramafic rock & \multicolumn{2}{|c|}{ not oriented } \\
\hline *K01-MB-11 & M9-13 & quartzofeldspathic gneiss & $300,80 \mathrm{~S}$ & \\
\hline \multicolumn{5}{|c|}{ Lester Mountain area } \\
\hline LM-00-08 & 13 & calc-silicate rock $(\mathrm{Xm})$ & $085,66 \mathrm{~S}$ & \\
\hline LM-00-12 & 15 & quartzofeldspathic gneiss & & \\
\hline LM-00-15 & 13 & amphibolite with garbanschiefer hbl texture & & \\
\hline *AT-01-L2 & $\mathrm{L} 2$ & Lester Mtn schist w/sill & $\sim$ S3: 094, 75S & \\
\hline *AT-01-L3 & L3 & mica schist near top of Lester mtn & $\mathrm{S} 2: 140,06 \mathrm{E}$ & \\
\hline *AT-01-L4 & L4 & mica schist above quartzite on Lester Mtn. & $\sim \mathrm{S} 2: 080,09 \mathrm{~N}$ & \\
\hline *AT-01-L6 & L6 & quartzite, Lester Mtn. (v.fine grained) & 010,90 (fracture) & $\begin{array}{l}070,86 \mathrm{~S} \\
\text { (F1 A.P.) }\end{array}$ \\
\hline AT-01-L7 & L7 & $\mathrm{S} 1 / \mathrm{S} 2 \&$ gar & $060,75 \mathrm{~S}$ & \\
\hline AT-01-L8 & 0.2 & Pearl Lake metavolcanic gneiss (Xpl) & $055,78 \mathrm{~W}$ & \\
\hline AT-01-L9 & 0.2 & Pearl Lake metavolcanic gneiss (Xpl) & FLOAT & \\
\hline *AT-01-L10 & 0.8 & gar-bio schist of Lester Mountain (Xgb) & S0-S1: $074,80 \mathrm{~N}$ & \\
\hline AT-01-L11 & O.10 & $\mathrm{Xgb}$ w/3 fabrics & $044,74 \mathrm{~N}$ & \\
\hline AT-01-L14 & O.17 & Q-musc schist w/3 fabrics & $084,34 \mathrm{~S}$ & \\
\hline *AT-01-L15 & O.17 & Q-musc schist w/3 fabrics \& sill & $\mathrm{S} 2: 090,50 \mathrm{~S}$ & \\
\hline *AT-01-L16 & O.18 & Q-fsp-bio gneiss & $\mathrm{S} 2: 135,88 \mathrm{~S}$ & \\
\hline *AT-01-L17 & O.18 & 3 orthogonal fabrics in mica schist & S2: $062,37 \mathrm{~S}$ & \\
\hline *AT-01-L19 & O.19 & gneiss w/leopard (calcsilicate) spots & $014,55 \mathrm{~W}$ & \\
\hline
\end{tabular}


Table 1, Lester Mountain area, continued.

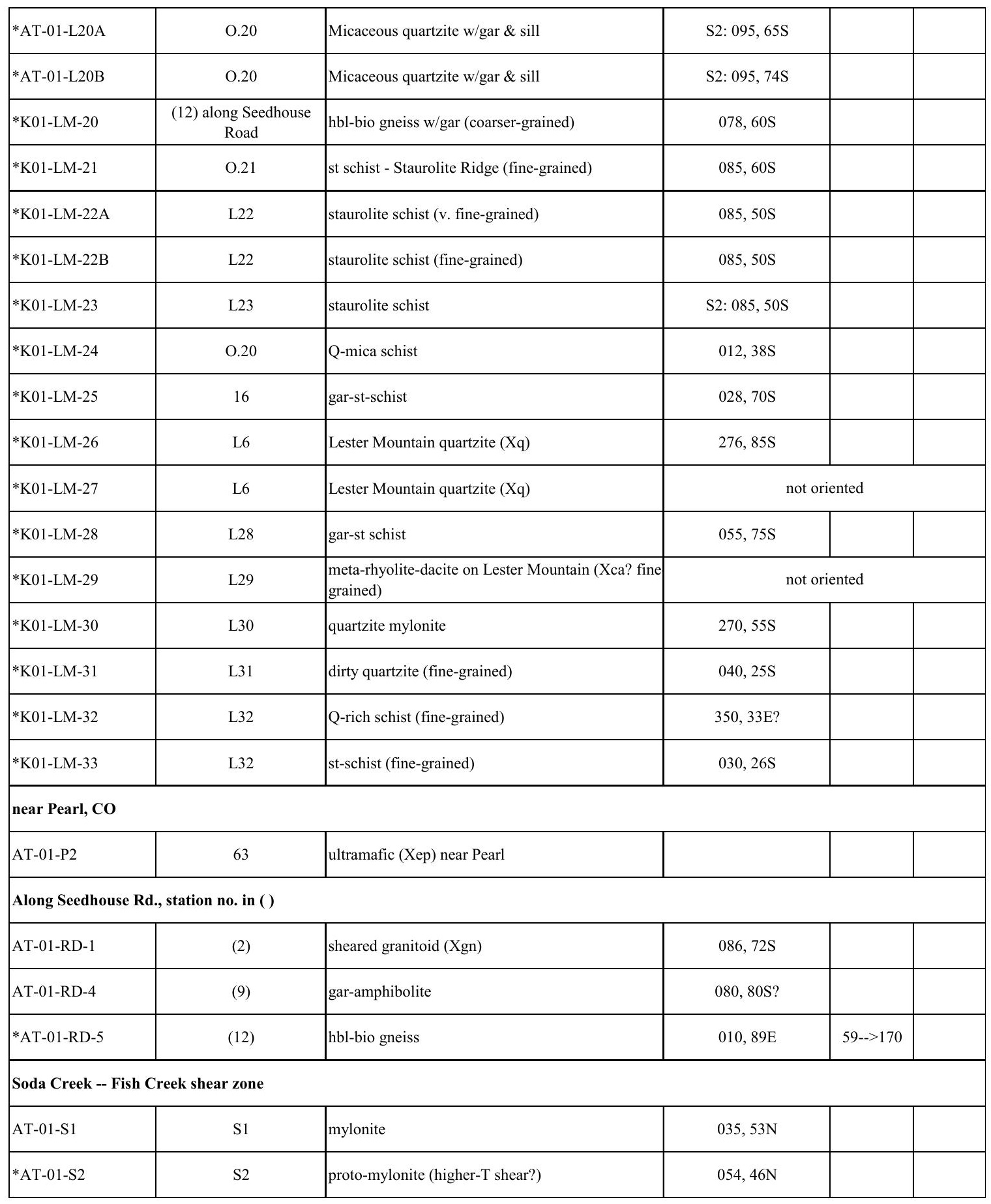


Table 2. Samples collected by K. Karlstrom during 1998-1999. Refer to Plates 4,6, and 7 for sample locations. S--foliation; L---lineation; A---fold measurements; Q---quartz; ksp---potassium feldspar; musc---muscovite; bio--biotite; chl---chlorite; hbl---hornblende; sill---sillimanite

\begin{tabular}{|c|c|c|c|c|c|c|}
\hline Field Area & Sample ID & Station No. & Lithology & $\mathbf{S}$ & $\mathbf{L}$ & $\mathbf{A}$ \\
\hline \multirow{13}{*}{$\begin{array}{c}\text { Soda Creek -- } \\
\text { Fish Creek } \\
\text { shear zone }\end{array}$} & K98-PK-12 & 6 & mylonitized gneiss (Xgn?) & $044,82 \mathrm{~N}$ & $82-->310$ & \\
\hline & K98-PK-13 & 6 & mylonitized gneiss (Xgn?) & $045,68 \mathrm{~N}$ & & \\
\hline & K98-PK-14 & 6 & Q-rich mylonite (Xgn?) & $070,78 \mathrm{~N}$ & & \\
\hline & K98-PK-15 & 6 & Q-rich mylonite (Xgn?) & $045,60 \mathrm{~N}$ & $45-->285$ & \\
\hline & K98-PK-17 & 9 & mylonite & $050,77 \mathrm{~N}$ & & \\
\hline & K98-PK-17a & 9 & Q-rich mylonite & $050,77 \mathrm{~N}$ & & \\
\hline & K98-PK-17b & 9 & Q-rich mylonite & $050,77 \mathrm{~N}$ & & \\
\hline & K98-PK-17c & 9 & Q-rich mylonite & $050,77 \mathrm{~N}$ & & \\
\hline & K98-PK-18 & 9 & bio-chl schist & & $53-->262$ & \\
\hline & K98-PK-20 & 10 & chloritized pseudotachylyte & $055,72 \mathrm{~N}$ & $6-->230$ & \\
\hline & K98-PK-21 & 11 & porphyry dike (Yp?) & $355,68 \mathrm{~W}$ & (Px) 50-->300 & \\
\hline & K98-PK-22 & 11 & $\begin{array}{l}\text { mylonitic shear band in Buffalo } \\
\text { Pass granite }(\mathrm{Xb}) \sim 2 \mathrm{~m} \text { wide }\end{array}$ & $080,76 \mathrm{~N}$ & 70 --> 305 & \\
\hline & K98-PK-23 & 11 & sheared Xgn@ dike margin & $006,77 \mathrm{~W}$ & & \\
\hline \multirow{12}{*}{ Lester Mountain } & K98-PK-24 & 13 & "calcsilicate" - amphibolite?? & $090,58 \mathrm{~S}(\mathrm{~S} 1 ?)$ & 32-->108 (L1?) & $\begin{array}{l}\text { (shallow } \\
\text { lineation) } \\
\end{array}$ \\
\hline & K98-PK-25a & 13 & chert (Xm) & & & \\
\hline & K98-PK-25b & 13 & $\begin{array}{l}\text { "marble" - fine-grained } \\
\text { carbonate }\end{array}$ & $\mathrm{S} 2 ? 062,55 \mathrm{~S}$ & L2? 54-->171 & $\begin{array}{c}\text { (steeper } \\
\text { lineation) } \\
\end{array}$ \\
\hline & K98-PK-26 & 13 & calcsilicate & $\begin{array}{c}\text { guess-field } 062, \\
65 \mathrm{~S}\end{array}$ & $\begin{array}{c}\text { lineation shallow } \\
\text { @ top, steep @ } \\
\text { bottom }\end{array}$ & \\
\hline & K98-PK-27a & 14 & Q-rich schist & $055,70 \mathrm{~S}$ & $\begin{array}{c}\text { fold axis plunge } \\
\sim 30 \mathrm{~W} \\
\end{array}$ & $\begin{array}{l}\text { cleavage } \\
115,63 \mathrm{~S} \\
\end{array}$ \\
\hline & K98-PK-27b & 14 & $\begin{array}{l}\text { sill pods in Q-rich schist (see } \\
27 \text { a) }\end{array}$ & & & \\
\hline & K98-PK-28 & 15 & sill pod rock (felsic gneiss) & $110,50 \mathrm{~S}$ & $\sim 6-->103$ & \\
\hline & K98-PK-30 & 30 & quartzite & & & \\
\hline & K98-PK-31 & 30 & Q-rich schist & & & \\
\hline & K98-PK-32 & 30 & Q-rich schist & & & \\
\hline & K98-PK-33 & 30 & quartzite & & & \\
\hline & K98-PK-34 & 30 & schist & & & \\
\hline
\end{tabular}


Table 2, continued.

\begin{tabular}{|c|c|c|c|c|c|c|}
\hline \multirow{8}{*}{$\begin{array}{c}\text { Soda Creek -- } \\
\text { Fish Creek } \\
\text { shear zone }\end{array}$} & KPK-99-50A & 50 & $\begin{array}{l}\text { deformed } \mathrm{Xb} \text { granite/ foliated } \\
\text { Leucogranite/ syn-F2 granite? }\end{array}$ & $\begin{array}{l}\text { S1: } 342,75 \mathrm{~W} \\
\text { S2: } 080,80 \mathrm{~S}\end{array}$ & & \\
\hline & KPK-99-50B & 50 & $\begin{array}{l}\text { deformed } \mathrm{Xb} \text { granite/ foliated } \\
\text { Leucogranite/ syn-F2 granite? }\end{array}$ & $\begin{array}{l}\text { S1: } 342,75 \mathrm{~W} \\
\text { S2: } 080,80 \mathrm{~S}\end{array}$ & & \\
\hline & KPK-99-50C & 50 & $\begin{array}{l}\text { deformed } \mathrm{Xb} \text { granite/ foliated } \\
\text { Leucogranite/ syn-F2 granite? }\end{array}$ & $\begin{array}{l}\text { S1: } 342,75 \mathrm{~W} \\
\text { S2: } 080,80 \mathrm{~S}\end{array}$ & & \\
\hline & KPK-99-51 & 50 & granitic pegmatite, pre-F2 & $050,60 \mathrm{~N}$ & & \\
\hline & KPK-99-52* & 50 & $\begin{array}{l}\text { amphibolite/bio gneiss screen in } \\
\mathrm{Xb}\end{array}$ & $315,85 \mathrm{~N}$ & & \\
\hline & KPK-99-53a & 54 & $\begin{array}{l}\text { 2-cm-wide mylonitic shear band } \\
\text { (see 53b) }\end{array}$ & $051,66 \mathrm{~N}$ & $61-->26 S$ & \\
\hline & KPK-99-53B & 54 & $\begin{array}{l}\text { mylonitic shear band (2-cm- } \\
\text { wide) }\end{array}$ & $051,66 \mathrm{~N}$ & $61-->265$ & \\
\hline & KPK-99-54 & 54 & $\begin{array}{l}\text { mylonitic shear band (2-cm- } \\
\text { wide) }\end{array}$ & $090,70 \mathrm{~S}$ & $36-->263$ & \\
\hline \multirow{11}{*}{ near Pearl, CO } & KPK-99-55 & 55 & $\begin{array}{l}\text { amphibolite, mylonite layered } \\
\text { w/marble \& calcsilicate }(\mathrm{Xm})\end{array}$ & $110,76 \mathrm{~S}$ & $72-->245$ & \\
\hline & KPK-99-56 & 55 & $\begin{array}{l}\text { mylonitic calc-silicate } \mathrm{w} / \mathrm{hbl} \& \\
\text { actinolite. }(\mathrm{Xm})\end{array}$ & $097,87 \mathrm{~S}$ & $63-->276$ & \\
\hline & KPK-99-57 & 55 & $\begin{array}{l}\text { pegmatite (deformed, in } \\
\text { calcsilicate) }\end{array}$ & $105,85 \mathrm{~S}$ & $56-->255$ & \\
\hline & KPK-99-58 & 58 & peridotite --> Sheila Seaman & & & \\
\hline & KPK-99-59 & 59 & sill pod rock & $005-90$ & $\sim 75-->0(Q$ pods $)$ & \\
\hline & KPK-99-60 & 59 & sill pod rock & $010,80 \mathrm{~W}$ & & \\
\hline & KPK-99-61 & 59 & musc-ksp pegmatite & & & \\
\hline & KPK-99-62 & 62 & $\begin{array}{l}\text { crenulated sill-bearing quartzite, } \\
\text { adjacent to pod rock }\end{array}$ & $352,78 \mathrm{E}$ & $30-->354$ & \\
\hline & KPK-99-63 & 63 & ultramafic w/orthoamphibole & 010,90 & & \\
\hline & KPK-99-64 & 63 & ultramafic. Peridotite? & & & \\
\hline & KPK-99-65 & 63 & amphibolite & $178,51 \mathrm{~W}$ & & \\
\hline
\end{tabular}


Table 3. Samples collected for geochronology by Kevin Chamberlain, University of Wyoming. Geochronologic results to date are listed in Appendix A, Table 1. All other results are pending. FM---Farwell Mountain area; MB---Mica Basin area; LM--Lester Mountain area; SCFC---Soda Creek -- Fish Creek shear zone.

\begin{tabular}{|c|c|c|c|}
\hline $\begin{array}{c}\text { ID of associated UNM } \\
\text { sample }\end{array}$ & $\begin{array}{l}\text { Station } \\
\text { No. }\end{array}$ & Sample Location and Lithology & Field relations \\
\hline $\mathrm{N} / \mathrm{A}$ & 3 & $\begin{array}{l}\text { [SCFC] Aplite in Buffalo Pass pluton } \\
\text { (Xb) near Buffalo Pass Rd. w/S1 \& S2 } \\
\text { foliations }\end{array}$ & $\begin{array}{l}\text { syn-S2 melt bands along limbs of folded S1 in } \\
\text { Xb. Aplite contains S1 and is folded by F2. }\end{array}$ \\
\hline $\mathrm{N} / \mathrm{A}$ & 3 & $\begin{array}{l}\text { [SCFC] Pre-D2 pegmatite in } \mathrm{Xb} \text { near } \\
\text { Buffalo Pass Rd. w/S1 \& S2 foliations }\end{array}$ & $\begin{array}{l}\text { Pegmatite locally crosscuts S1 and is folded by } \\
\text { F2 }\end{array}$ \\
\hline $\mathrm{N} / \mathrm{A}$ & 3 & [SCFC] hornblende-pegmatite & $\begin{array}{l}\text { syn-S2 melt bands along limbs of folded S1 in } \\
\text { Xb. Pegmatite crosscuts S1 and is folded by S2 } \\
\text { but is less folded than country rock }\end{array}$ \\
\hline$K 98-P K-12-15$ & 6 & [SCFC] old gray gneiss (Xgn) & $\begin{array}{l}\text { mylonite-ultramylonite zone ("D3" has shallow } \\
\text { thrust and sinistral strike-slip senses of motion) }\end{array}$ \\
\hline $\mathrm{N} / \mathrm{A}$ & 7 & $\begin{array}{l}{[\mathrm{SCFC}] \text { post- or latest syn-S1 pegmatite }} \\
\text { at the contact of the Buffalo Pass pluton } \\
(\mathrm{Xb})\end{array}$ & $\begin{array}{l}\text { Melt-filled gashes suggest sinistral strike-slip } \\
\text { and north-side-down sense of motion at high } \\
\text { temperature. Pegmatite is zoned and crosscuts } \\
\mathrm{S} 1 \text { but there is a slight deflection of S1 at its } \\
\text { margin. }\end{array}$ \\
\hline $\mathrm{N} / \mathrm{A}$ & 8 & [SCFC] amphibolite dike (in Xgn) & $\begin{array}{l}\text { Dike is laterally offset } 1.5 \mathrm{~m} \text { by a } 5-\mathrm{cm} \text {-wide } \\
\text { mylonitic shear band }\end{array}$ \\
\hline K98-PK-17-19 & 9 & $\begin{array}{l}\text { [FM-LM suture zone] } \\
\text { calcsilicate/mylonite }\end{array}$ & $\begin{array}{l}\text { "D3" mylonititic shear zone }(\sim 10 \mathrm{~m} \text { wide }) \text { in } \\
\text { marble unit }(\mathrm{Xm}) \text {, conjugate ultramylonitic } \\
\text { shear bands indicate shortening }\end{array}$ \\
\hline $\mathrm{N} / \mathrm{A}$ & 12 & [SCFC?] pre-S1 aplite & folded by F2 \\
\hline N/A & 12 & [SCFC?] granodiorite (possibly Xb) & contains S1 \\
\hline FM-00-01 & F1 & $\begin{array}{l}\text { [FM] clasts of plagioclase-porphyritic } \\
\text { andesite in a dacitic matrix (volcanic } \\
\text { agglomerate in Xca unit) }\end{array}$ & $\begin{array}{l}\text { strongly lineated and foliated, clast aspect ratio } \\
\text { 10:1.2:1 }\end{array}$ \\
\hline$F M-00-02$ & F1 & $\begin{array}{l}{[\text { FM] Xca - garnet-bearing clast from }} \\
\text { float }\end{array}$ & metasedimentary (?) portion of Xca map unit \\
\hline $\mathrm{N} / \mathrm{A}$ & & $\begin{array}{l}{[\text { SCFC] } 2000 \text { samples from Buffalo }} \\
\text { Mountain }\end{array}$ & $\begin{array}{l}\text { field relations similar to those in } \mathrm{Xb} \text { in shear } \\
\text { zone }\end{array}$ \\
\hline$K 01-M B-1$ & \multirow{4}{*}{\multicolumn{2}{|c|}{$\begin{array}{l}{[\mathrm{MB}] \text { outcrop at jct of Mica Basin \& Gilpin Lake }} \\
\text { trails; \#s 1-4 rep. Sequence determined from field } \\
\text { relationships }\end{array}$}} & amphibolitic gabbro \\
\hline$K 01-M B-2$ & & & grey dioritic-granodioritic gneiss \\
\hline K01-MB-3 & & & syn-D2 granitoid \\
\hline K01-MB-4 & & & crosscutting pegmatite dikes \\
\hline K01-LM-27 & & $\begin{array}{l}\text { [LM] Quartzite }(X q) \text { east side, top of } \\
\text { Lester Mountain }\end{array}$ & Quartzite from Lester Mountain - detrital zircons \\
\hline K01-LM-29 & & $\begin{array}{l}\text { [LM] Rhyolitic-to-dacitic clast-bearing } \\
\text { unit on north side, top of Lester } \\
\text { Mountain that is correlated (pending } \\
\text { geochronologic results) to Xca } \\
\text { conglomerate/agglomerate at Farwell } \\
\text { Mountain }\end{array}$ & Xca rhyolite-dacite from Lester Mountain \\
\hline
\end{tabular}




\section{APPENDIX D. STRUCTURAL AND GEOCHRONOLOGIC EVIDENCE FOR DEFORMATIONAL HISTORY ${ }^{1}$}

\section{INTRODUCTION}

Seismic, metamorphic, and geochronologic data indicate that the Farwell Mountain - Lester Mountain zone is likely an important tectonic boundary. In the following section, we attempt to use the techniques of structural geology to unravel the deformation sequence and kinematic history of the zone. To accomplish this, we have independently investigated four key field areas of Paleoproterozoic outcrop that may lie within the paleo-suture zone: Farwell Mountain, Mica Basin, Lester Mountain, and the Soda Creek - Fish Creek shear zone. The Farwell Mountain (Appendix C, Plate 3) and Lester Mountain (Appendix B, Plate 1c) areas were chosen for detailed study in order to further assess the relevance of the metamorphic break identified between them by Foster et al. (1999). Also, the Lester Mountain area includes the only quartzite-pelitic schist package in the region, which alerts us to the possibility that this area preserves information about the suturing event(s) that is not preserved elsewhere.

The unusual map pattern and "swirling foliation trajectories" in the Mica Basin area [Appendix B, Plate 1b; Appendix C Plate 5 (Snyder, 1980)] have made it the focus of previous studies: Kennedy (1992) attributed the swirling pattern to a vortex created at

\footnotetext{
${ }^{1}$ Refer to Tables 1, 2 (at end of this appendix) for detailed thin section descriptions of all samples analyzed. Some of these will be discussed in the text below. Table 5 (at end of this appendix) lists the structural data used to generate stereonet plots in figures in this appendix. Plate 8 shows foliation trends so that stereonet plots may be considered in the regional context.
} 
the margin of the intruding pluton ${ }^{2}$. It is also possible that interference patterns made by multiple fold generations could explain the complexity of the foliation trajectories in the Mica Basin area, and the following discussion provides evidence to that effect.

The Soda Creek - Fish Creek shear zone (Appendix C, Plate 7) was identified by Snyder (1980) as a 6-km-wide high-strain zone with anastomosing mylonite strands. This and the work of others (Eiler, 1989; Chaplinsky, 1987; Barinek et al., 1999) demonstrate that the shear zone has a history of multiple movements and thus that it is an important structural zone. However, there is no clear evidence to suggest that the shear zone separates tectonic blocks with different histories (Eiler, 1989; Chaplinsky, 1987), and seismic reflection data reveal no major shallow structures in the crust beneath the shear zone (Morozova et al., 2002). Thus, if the shear zone persists as a major structural zone at depth, it must be steep and may preserve little of the original accretionary structure, if it is part of a low-angle, broad "Farwell Mountain - Lester Mountain suture zone". It may, however, be an important subvertical zone, for example to accommodate cryptic transcurrent motions pre-, syn- and/or post-suturing. The proximity of the shear zone to the proposed suture zone, the intrusion of the ca. $1.42 \mathrm{Ga}$ Mount Ethel pluton along its margin, and the available age constraints on its structural and metamorphic fabrics make it an important part of this study.

Ultimately, we are able to formulate a working hypothesis that correlates the timing of fabrics among the four areas and tentatively assigns them absolute ages based on available geochronologic data (Table 3, at end of this appendix). Partial PressureTemperature-time-deformation (P-T-t-D) paths are constructed for the Farwell Mountain

\footnotetext{
${ }^{2}$ In this study it is considered to be the Elkhorn Mountain/Seven Lakes plutonic complex that intrudes the Mica Basin area, pending geochronologic results for samples collected in 2002.
} 
(Figure 1a), Mica Basin (Figure 1b), and Lester Mountain (Figure 1c) areas, and the Soda Creek - Fish Creek shear zone (Figure 1d). By comparing these paths, it is then possible to speculate on the character and kinematic history of the zone as a whole. Unlike the through-going shear zone which characterizes the Cheyenne belt, the "Farwell Mountain - Lester Mountain suture zone" appears to be a wide, distributed, imbricated, ductile middle crustal zone that we infer to have a duplex-type geometry (Plate 2; Karlstrom and Williams, in press). If our interpretations are correct, progressive shortening after the original suturing event has largely obscured the accretionary structures at the middlecrustal levels which are now exposed. Nevertheless, we are able to discern much about earlier fabrics through careful field and petrologic study focused on opportunities to see through the overprinting. 


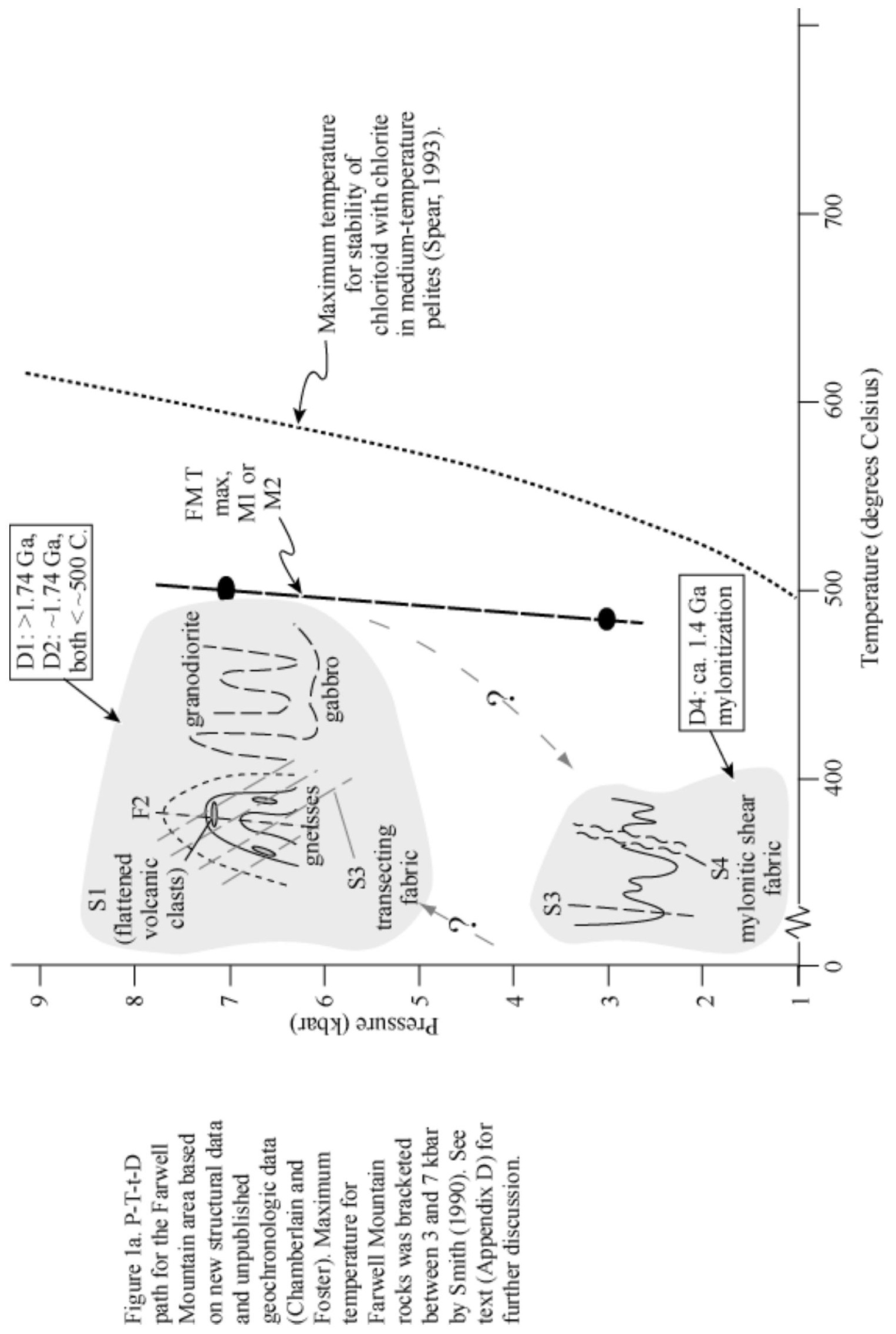




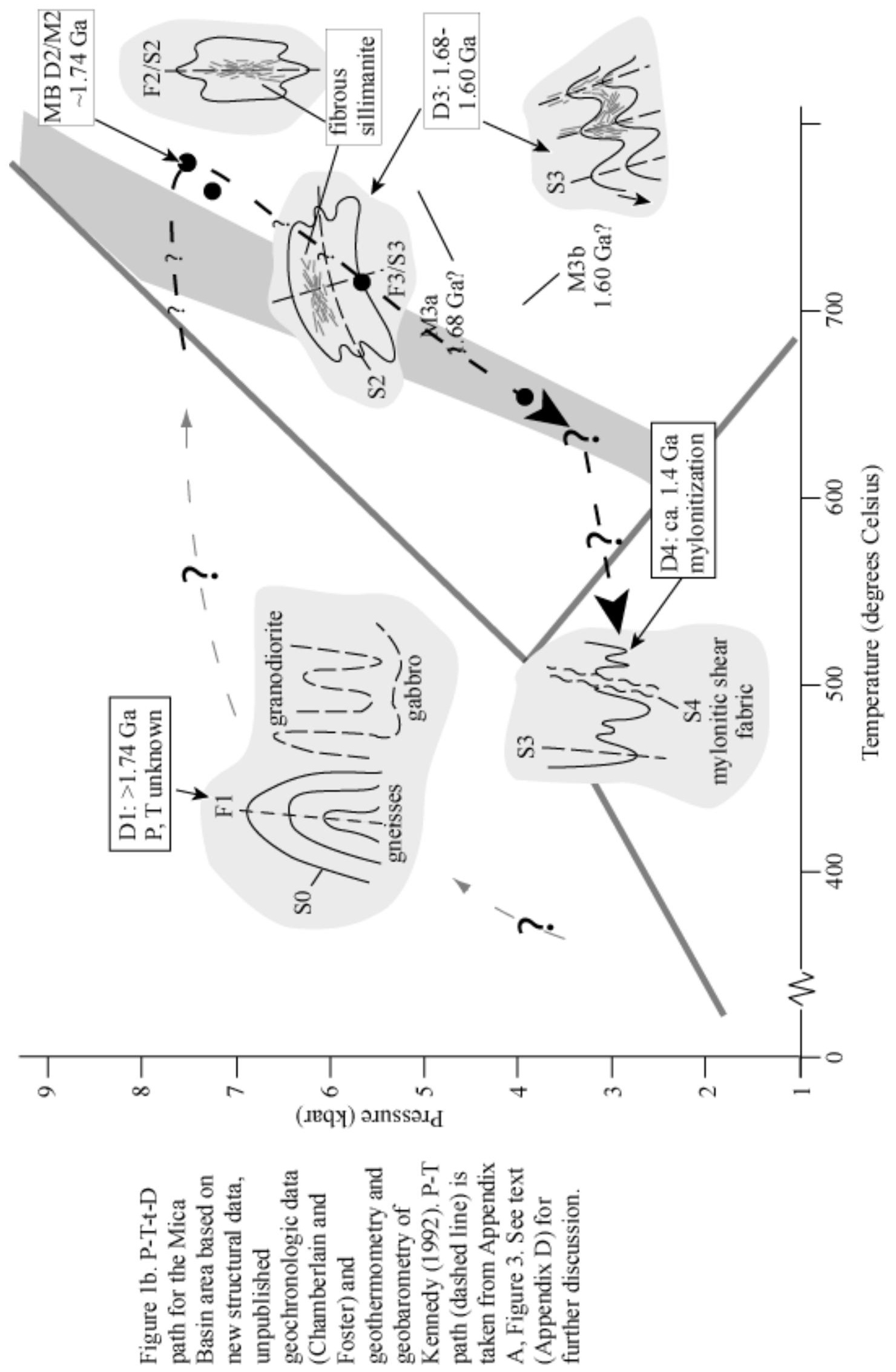




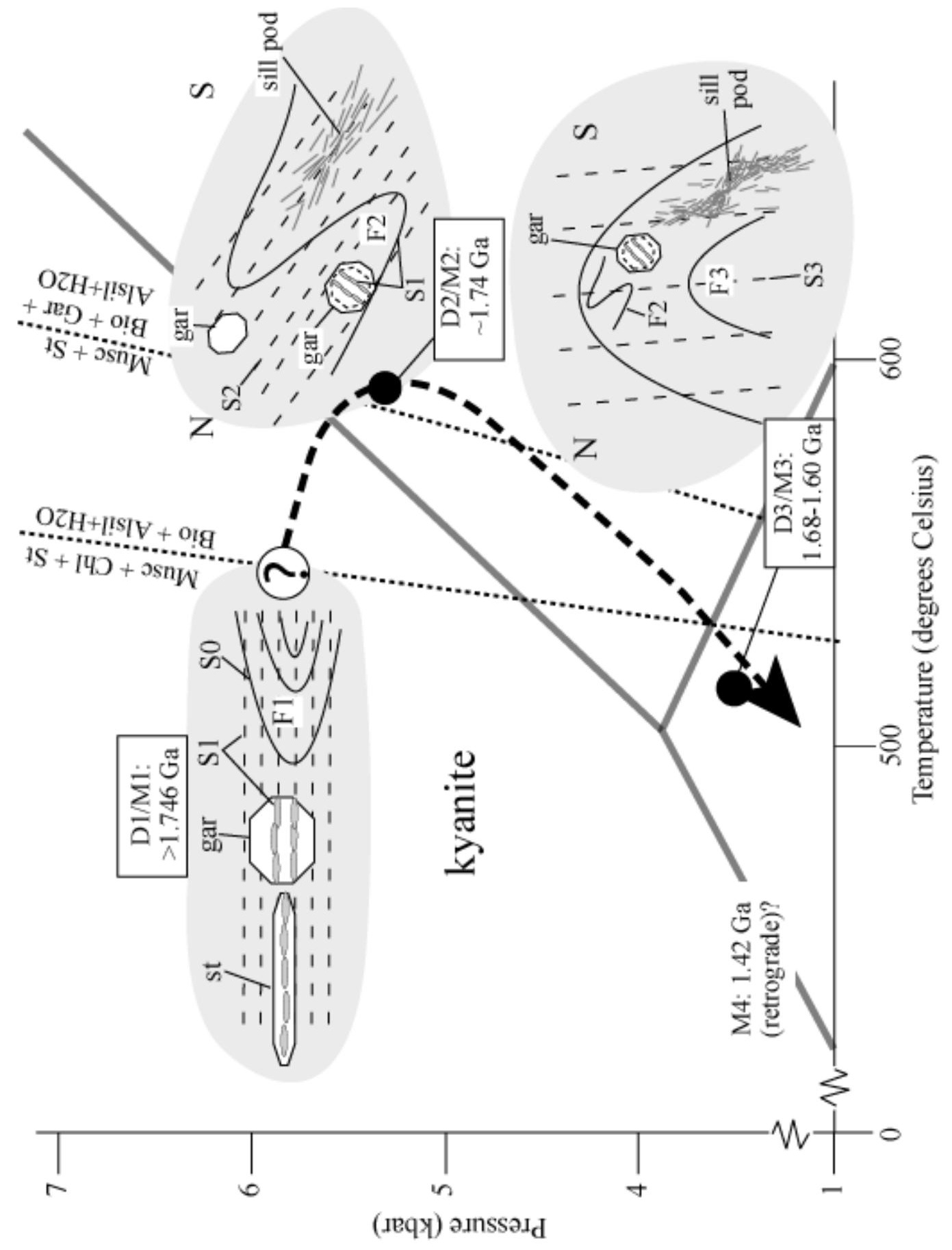

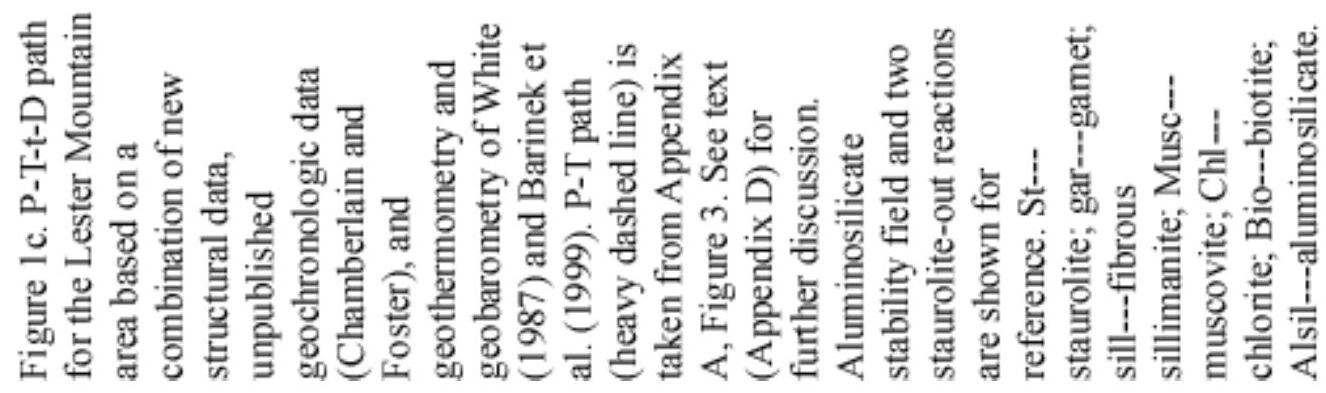




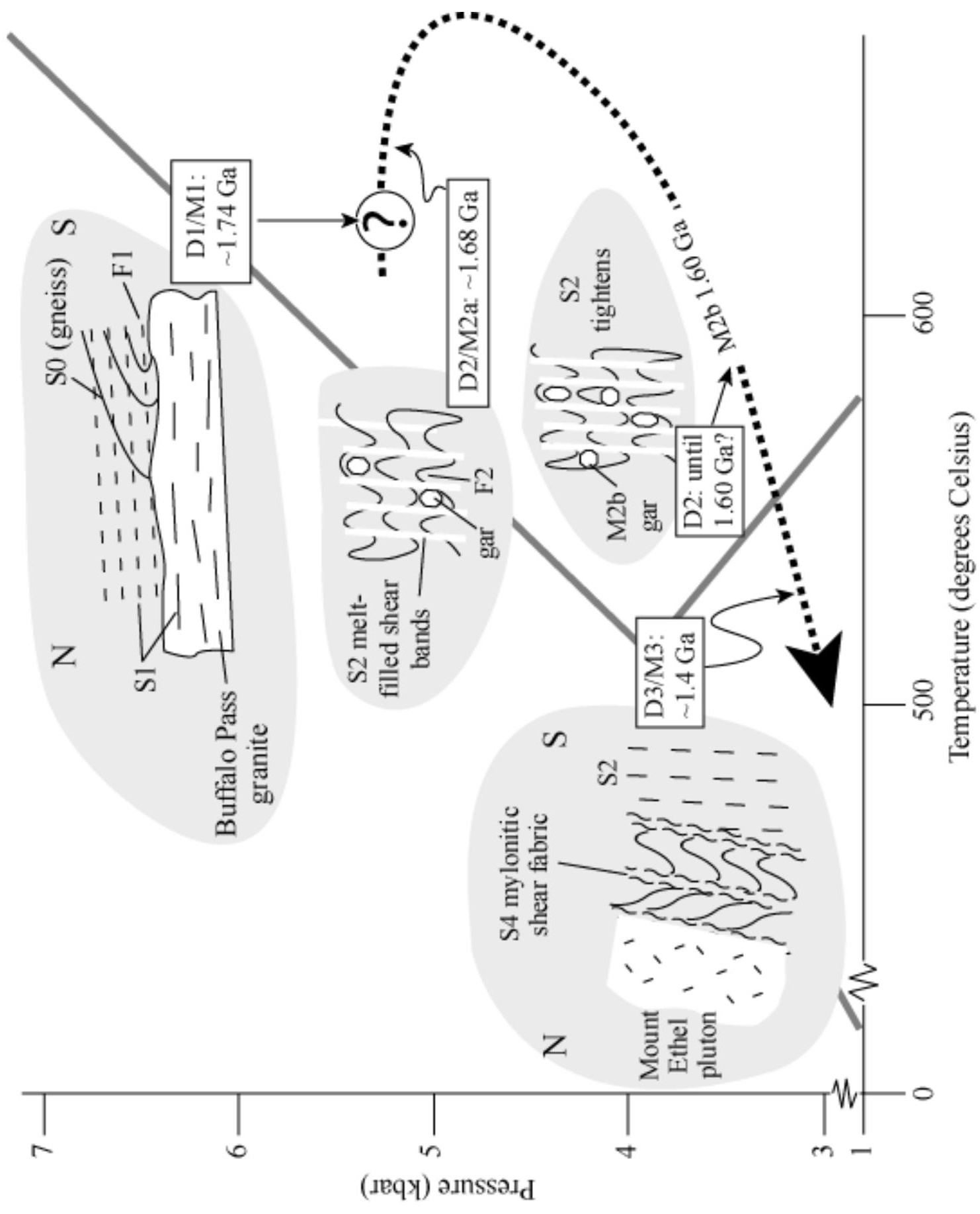

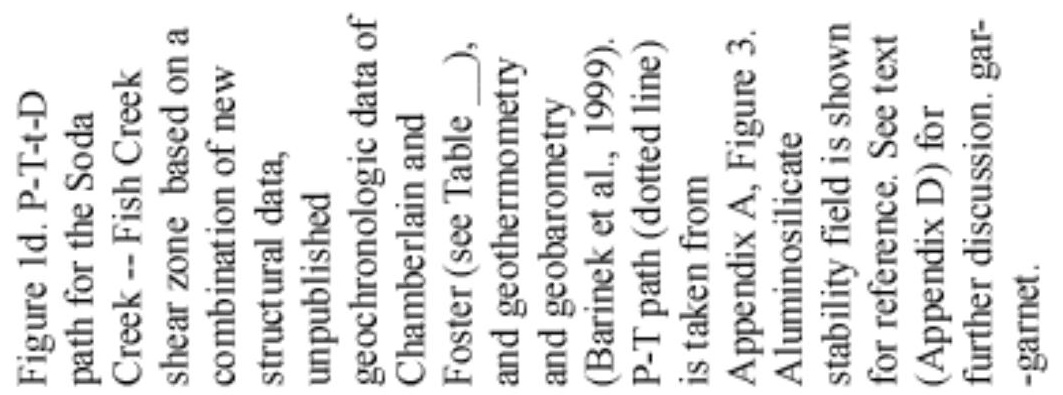




\section{FARWELL MOUNTAIN}

The hypothesis presented here for the kinematics and sequence of deformation events in the Farwell Mountain area is based on new field data and considers the previous work of Snyder (1980) and Smith (1990). Four major generations of ductile fabrics are identified:

(1) $D_{1}=$ formation of $S_{1}$ bedding-subparallel tectonic layering in supracrustal rocks and the body of Elkhorn Mountain gabbro on Farwell Mountain. Volcanic clasts and graded bedding preserve the subhorizontal depositional layering $\left(\mathrm{S}_{0}\right)$ in some supracrustal rocks (Xca). Clasts are elongate and flattened (Figure 2a) in an $\mathrm{S}_{0}-\mathrm{S}_{1}$ composite fabric. The original orientation of $\mathrm{S}_{1}$ is unknown.

(2) $D_{2}=$ transposition of $S_{0}-S_{1}$ into an unknown $S_{2}$ orientation via $F_{2}$ isoclinal folds (Figure 2b). Mafic dikes (Xeb) crosscut the Xca and both are folded by $\mathrm{F}_{2}$; the dikes may be syn- $D_{2}$. The $\mathrm{S}_{0}-\mathrm{S}_{1}$ and $\mathrm{S}_{2}$ fabrics are folded by $\mathrm{F}_{3}$ and thus their original orientations are also unknown (Figure 3a).

(3) $\mathrm{D}_{3}=$ development of an east- to northeast-striking, subvertical $\mathrm{S}_{3}$ foliation with an average orientation of $274^{\circ}, 79^{\circ} \mathrm{N}$ (photo, Figure $3 b$ ). $S_{3}$ transects $F_{2}$ folds (Figure 2b) and parallels the transecting fabric and east-west striking, subvertical $\mathrm{F}_{3}$ axial planes observed throughout the Park Range. Stereonet plots show that $\mathrm{F}_{3}$ fold axes have an average orientation of $72^{\circ} \rightarrow 030^{\circ}-050^{\circ}$ (Figure 3a) and $\mathrm{L}_{3}$ stretching lineations have an average orientation of $73^{\circ} \rightarrow 045^{\circ}$ (Figure 3c). This subparallelism between the fold axis and stretching direction may reflect a 
constrictional strain field during $\mathrm{D}_{3}$ or the rotation of all lines to subvertical orientations during $\mathrm{D}_{3}$ and/or subsequent shortening.

(4) $\mathrm{D}_{4}=$ mylonitic shear along isolated, northeast-striking, subvertical shear bands in the Seven Lakes quartz monzonite (Xsl). Mylonites have an average orientation of $241^{\circ}, 85^{\circ} \mathrm{N}$ (Figure 3d), crosscut all other ductile fabrics, and are inferred to correlate with ca. 1.4 Ga mylonitization in the Soda Creek - Fish Creek shear zone. 


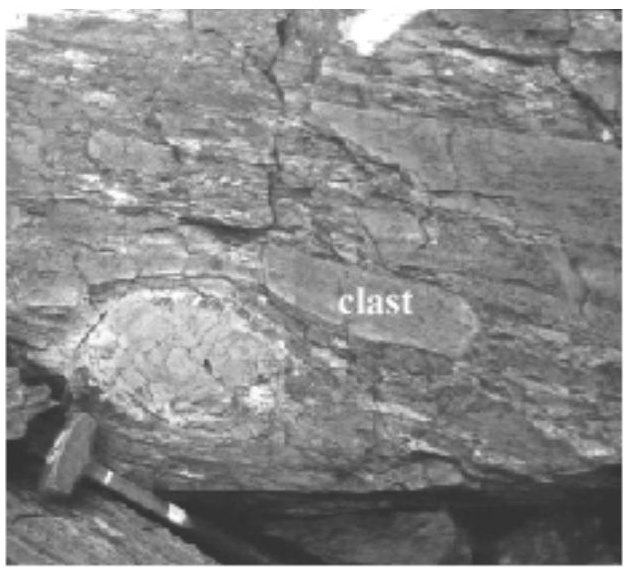

Figure 2. Field photographs. a. (above) Cross-sectional view looking northeast at flattened (S1) volcanic clasts (S0) in the rhyo-dacitic agglomerate (Xca) of Farwell Mountain. b. (right) F2 fold in metasedimentary layers of the Xca map unit at Farwell Mountain. Micas aligned in S3 transect the fold.
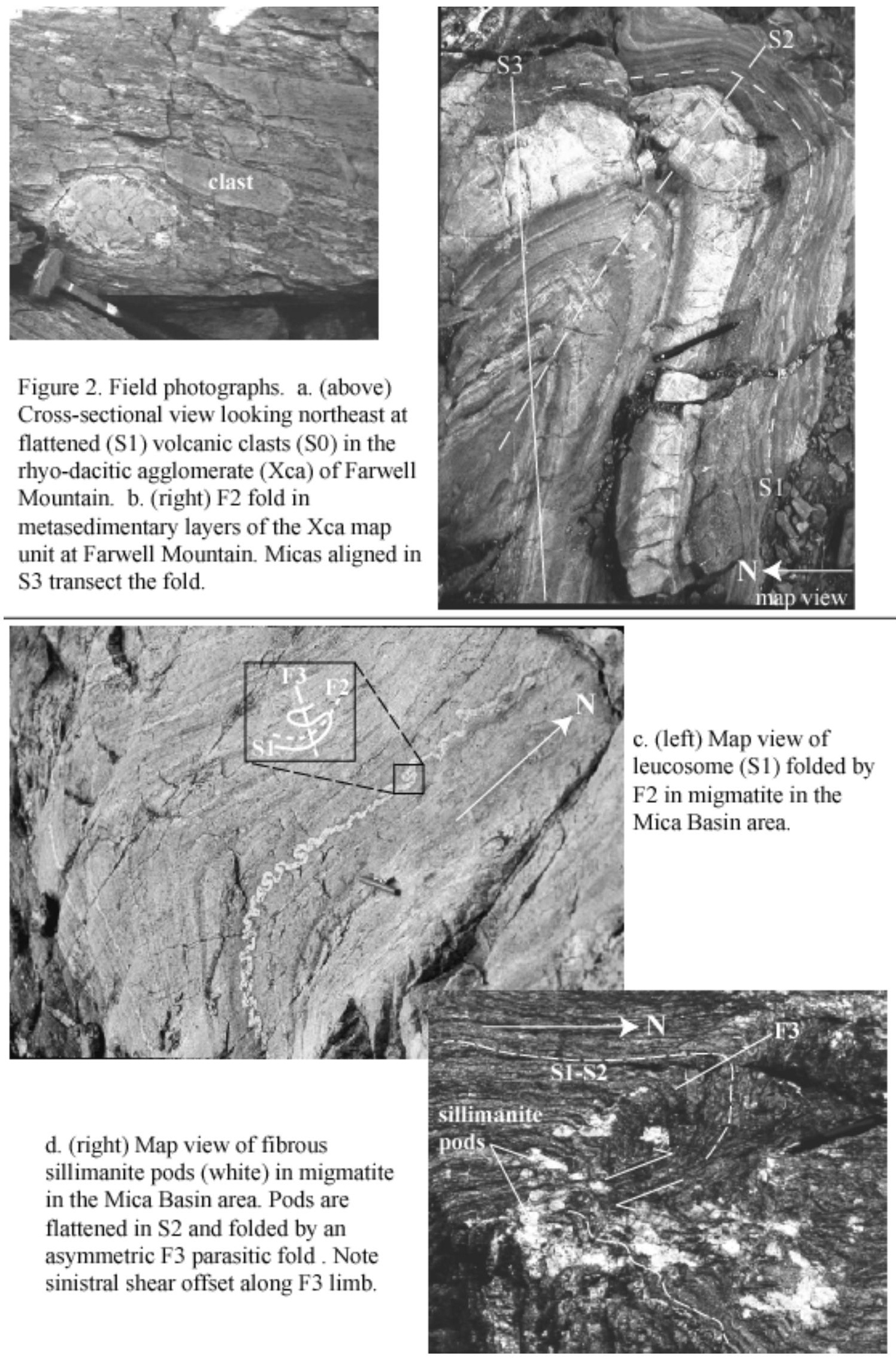


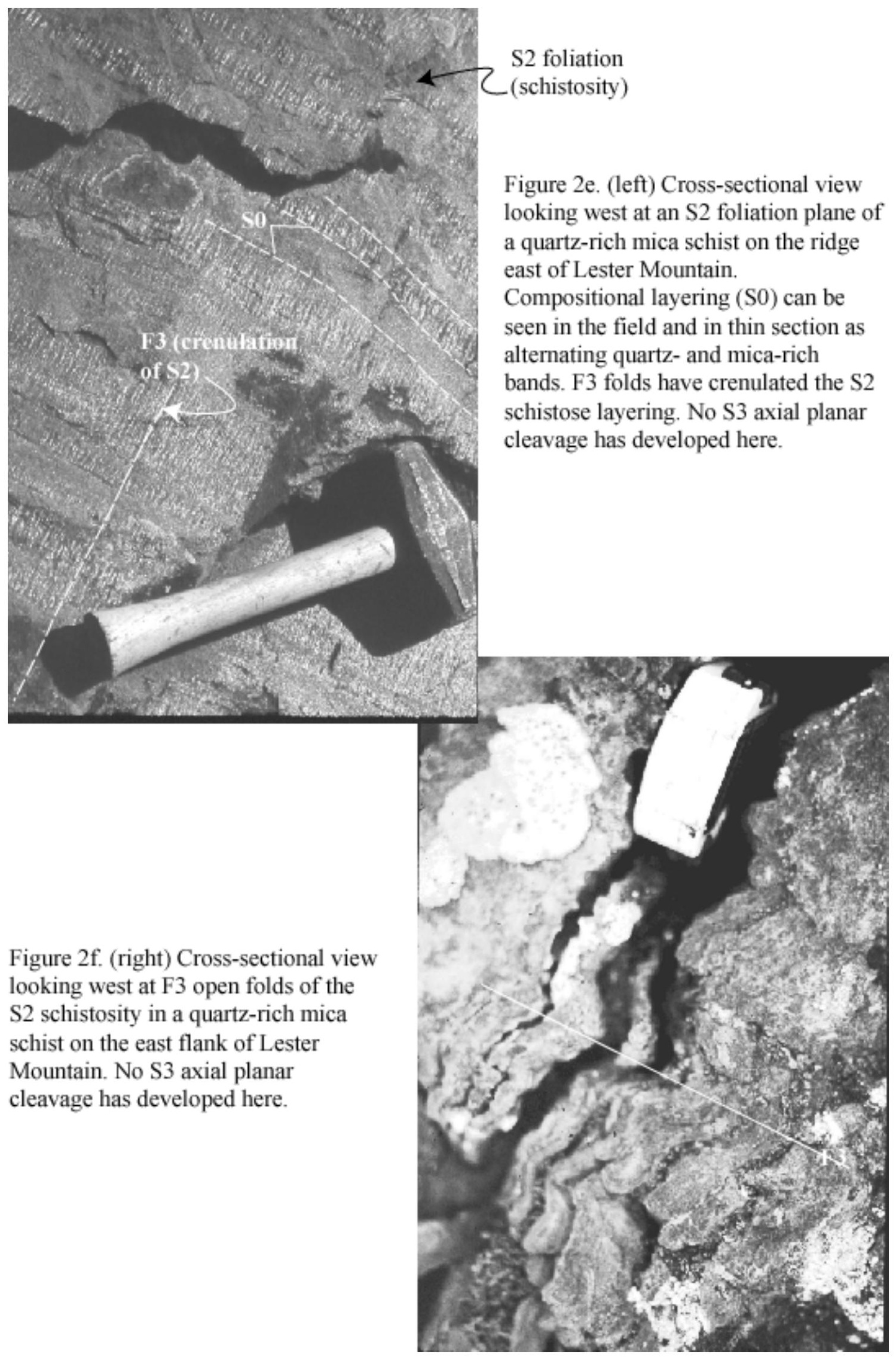




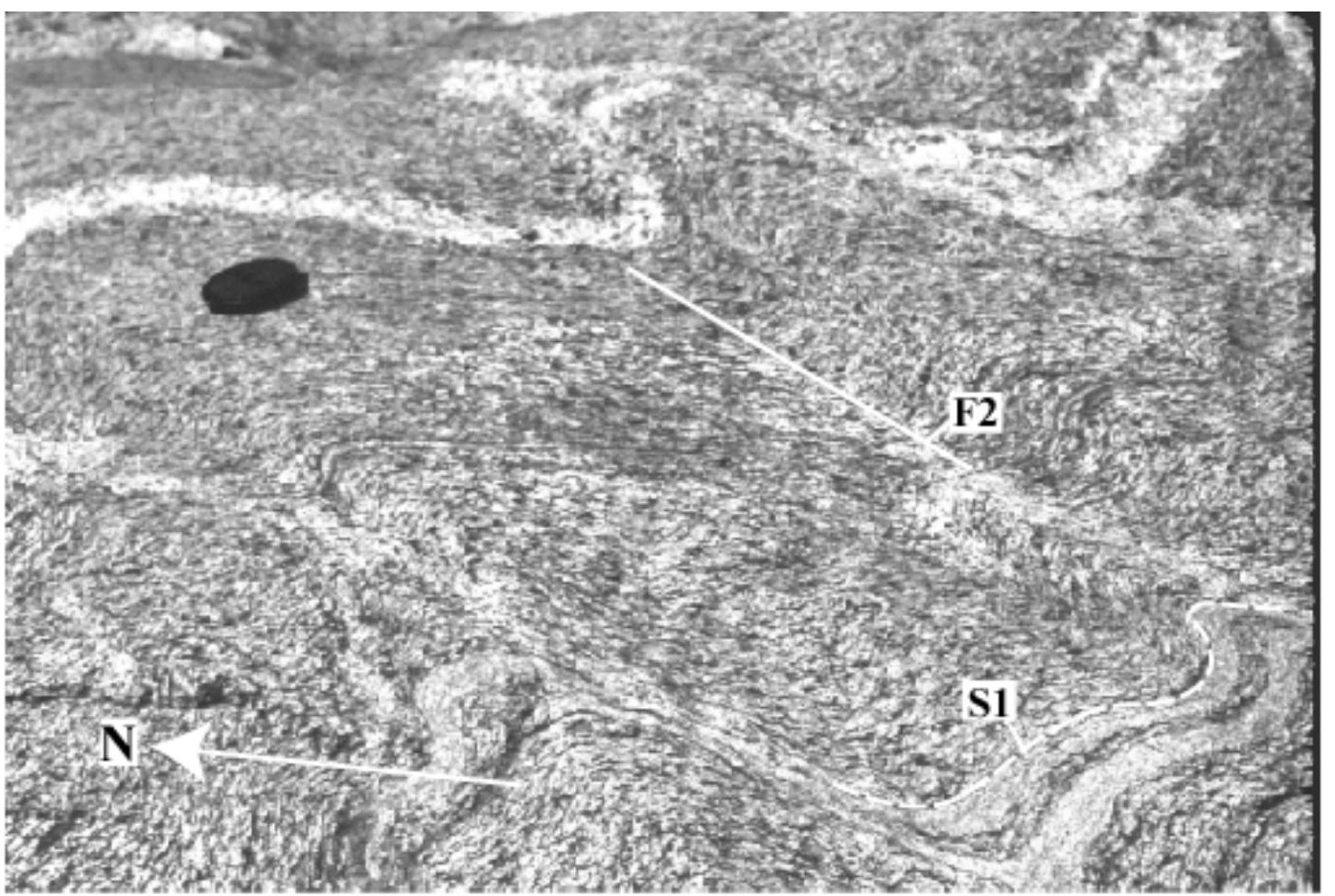

Figure 2g. (above) Map view of folding of S1 tectonic fabric in the $1746 \mathrm{Ma}$ Buffalo Pass granite by F2 folds with northeast-striking, subvertical axial planes. S2 melt-filled shear bands have formed along F2 limbs.

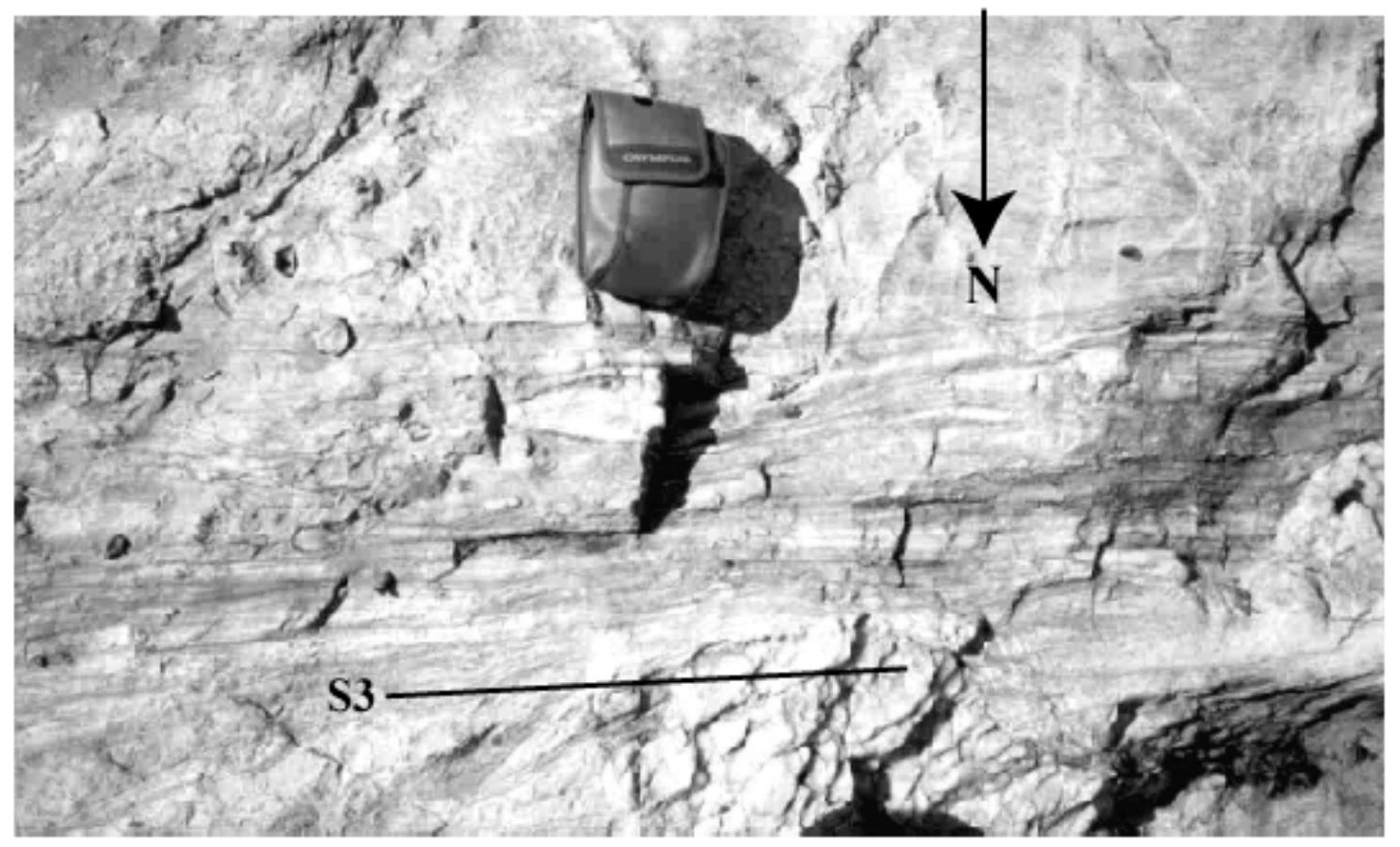

Figure 2h. (above) Map view of mylonitic shear bands (S3) cutting higher-temperature fabrics in the Soda Creek -- Fish Creek shear zone. This photograph shows a subvertical mylonitic to ultramylonitic shear band in the Buffalo Pass granite. 


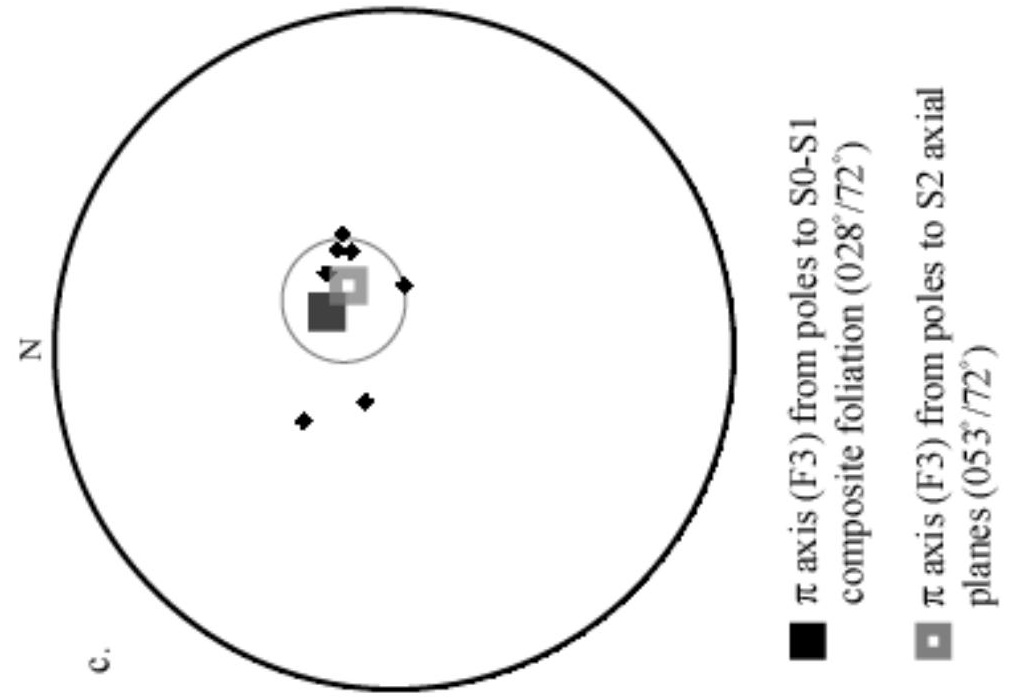

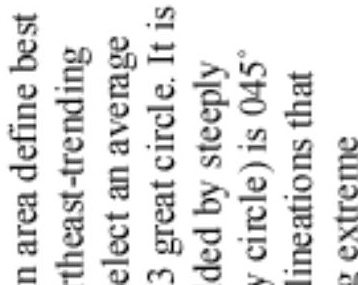

高

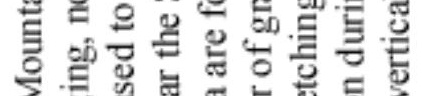

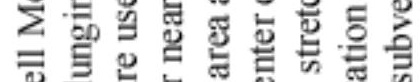

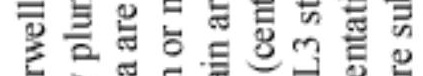

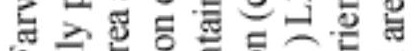
월

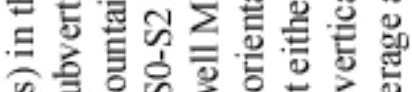

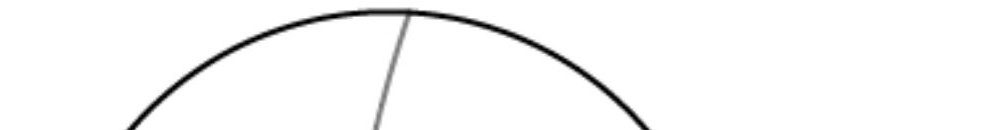

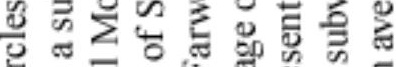
政=

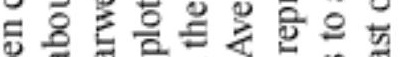
응

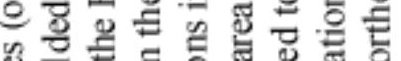

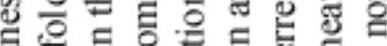

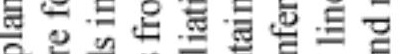

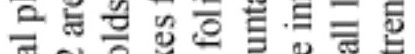

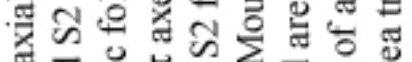

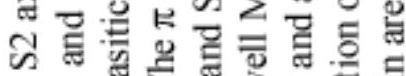

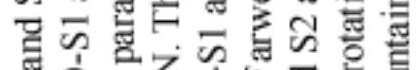

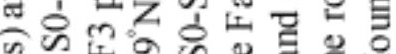

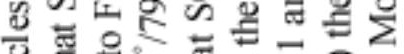

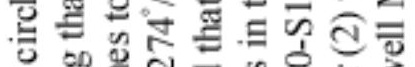

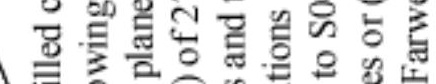

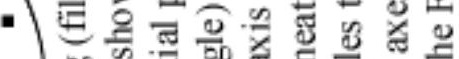
on

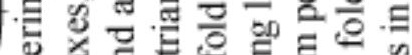

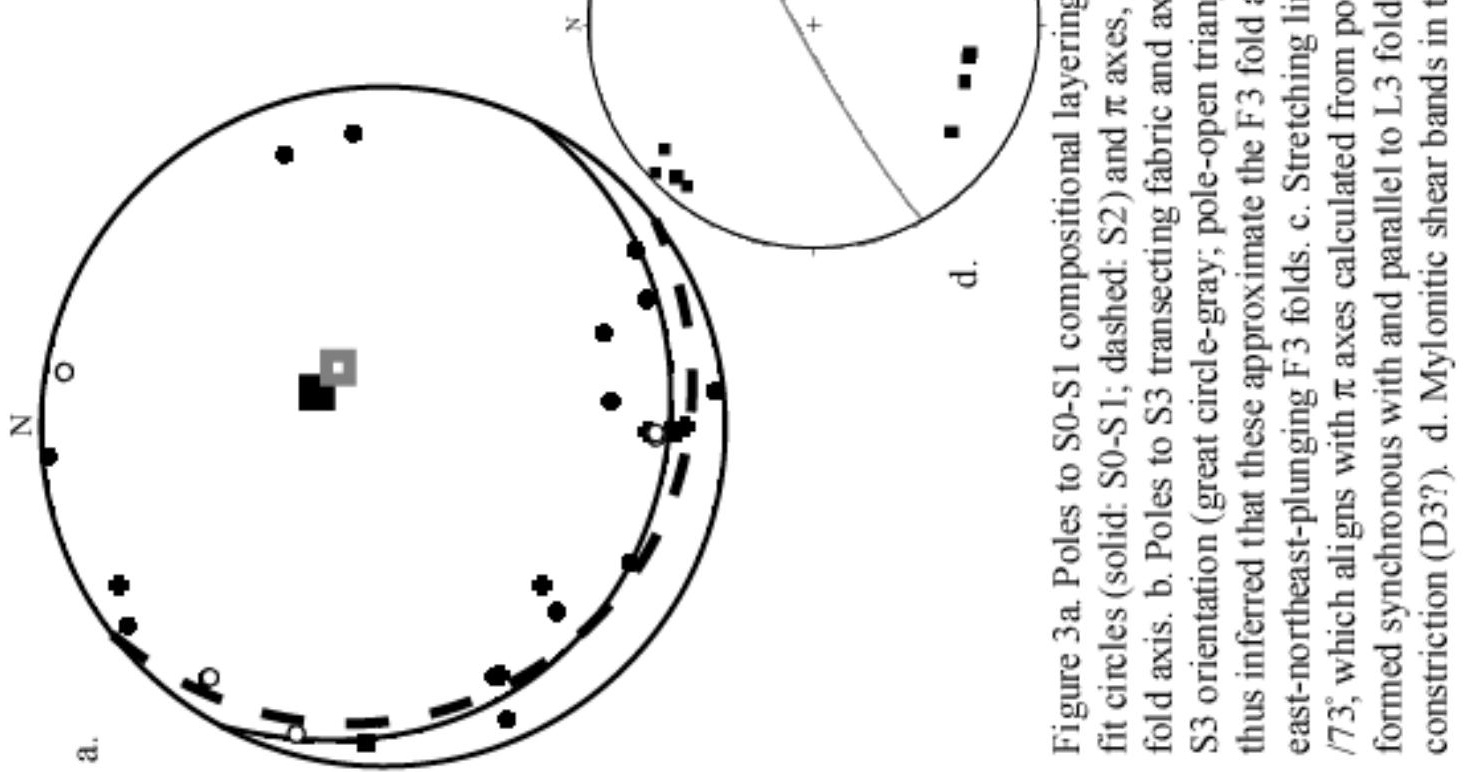


$\mathrm{S}_{1}$ tectonic layering is often cryptic and overprinted by later fabrics. The conglomerate/agglomerate (Xca; Snyder, 1980) at Farwell Mountain has a rhyodacitic matrix surrounding plagioclase-porphyritic volcanic clasts of rhyolitic-to-andesitic composition. The clasts are flattened parallel to $\mathrm{S}_{1}$ and have an angular elongate aspect ratio of about 10:1, showing some constrictional component to the finite strain; the rock itself is an L-tectonite with a very weak foliation. Metasedimentary layers within the Xca map unit may be metaturbidites. In some finer layers, cordierite is flattened in $\mathrm{S}_{2}$ (syn$\left.\mathrm{S}_{2}\right)$.

Epidote-filled faults in Xca are roughly east-west trending and steeply dipping with observed sinistral offset of pegmatite dikes. These may represent post- $\mathrm{D}_{4}$ deformation during exhumation and/or Laramide reactivation of basement structures.

\section{MICA BASIN}

The sequence of deformation events in the Mica Basin area can be correlated with that in the Farwell Mountain area as follows:

(1) $\mathrm{D}_{1}=$ development of $\mathrm{S}_{0}-\mathrm{S}_{1}$ composite gneissic and migmatitic layering in metasedimentary and metavolcanic rocks, shown by the parallelism of compositional and tectonic layering throughout the area. $\mathrm{S}_{0}$ is considered to be the originally horizontal depositional layering in the supracrustal rocks. The original orientation of $\mathrm{S}_{1}$ is unknown.

(2) $\mathrm{D}_{2}=$ folding of $\mathrm{S}_{0}-\mathrm{S}_{1}$ by $\mathrm{F}_{2}$ isoclinal (Figure $2 \mathrm{c}$ ) and closed O-shaped folds, indicative of extreme shortening and possibly of constrictional strain. The $\mathrm{S}_{0}-\mathrm{S}_{1}$ composite foliation has been largely transposed into $\mathrm{S}_{2}$ (both $\mathrm{S}_{0}-\mathrm{S}_{1}$ and $\mathrm{S}_{2}$ 
foliations have great circle distributions which define the $\mathrm{F}_{3}$ fold axis, discussed below) in most exposures (Figure $4 a, b$ ) and is distinguishable only in $F_{3}$ hinges.

(3) $\mathrm{D}_{3}=$ refolding of $\mathrm{S}_{0}-\mathrm{S}_{1}$ and $\mathrm{S}_{2}$ by open $\mathrm{F}_{3}$ folds (field photo) with subvertical axial planes that have an average orientation of $245^{\circ}, 80^{\circ} \mathrm{N}$ (Figure 4c). Regional $\mathrm{F}_{3}$ fold axes plunge steeply west-southwest: $65^{\circ} \rightarrow 233^{\circ}$ based on $\mathrm{S}_{0}-\mathrm{S}_{1}$ (Figure 4a) and $72^{\circ} \rightarrow 263^{\circ}$ (Figure $4 b$ ) based on $S_{2}$ orientations. The average $L_{3}$ stretching lineation orientation is $78^{\circ} \rightarrow 236^{\circ}$ (Figure 4d). This subparallelism between the fold axis and stretching direction may represent the strain field during $D_{3}$ or the rotation of all lines to subvertical orientations during $D_{3}$ and/or subsequent shortening. 

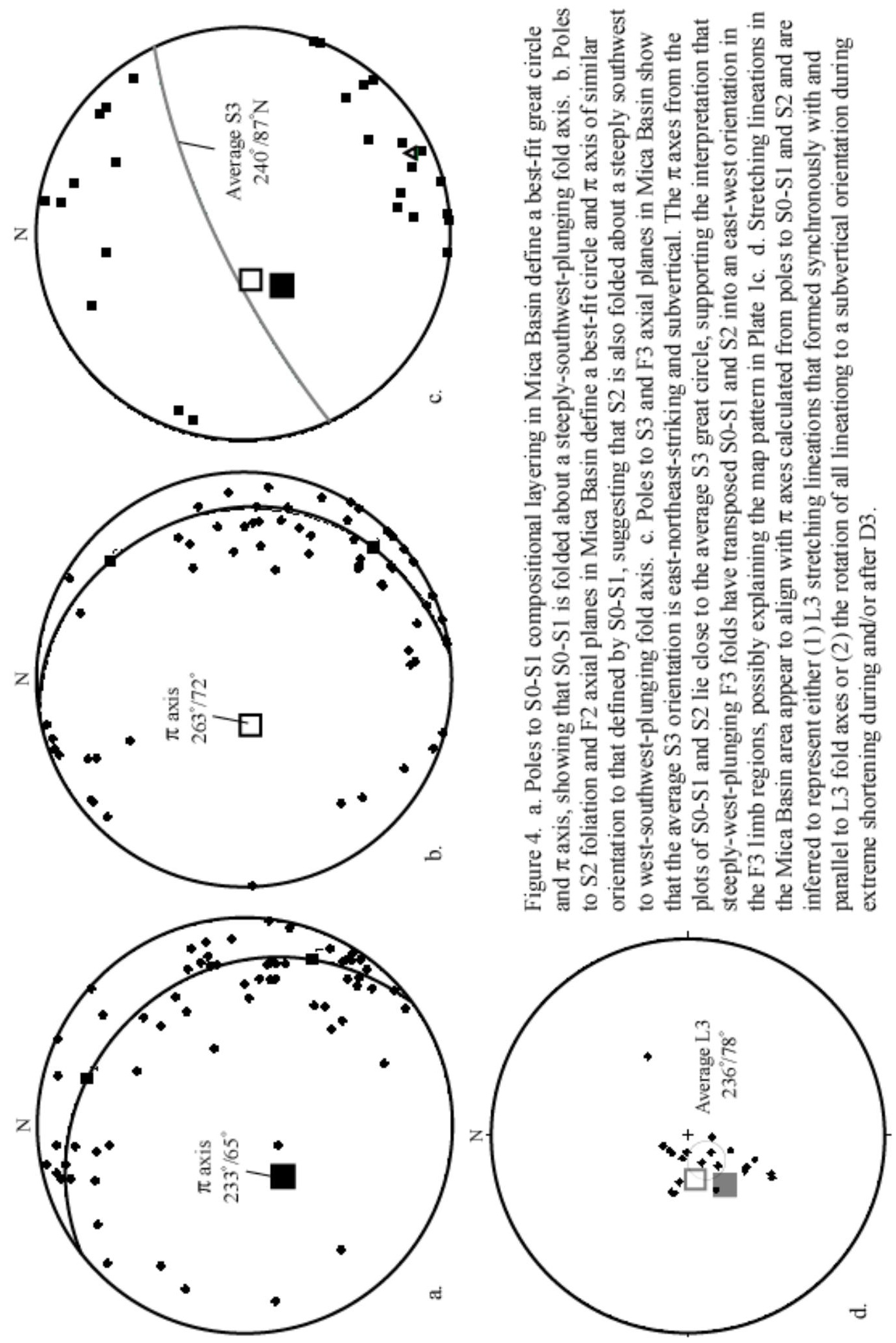
It is important to note that the $\mathrm{F}_{3}$ folds in the Farwell Mountain and Mica Basin areas plunge steeply in opposite directions: northeast and southwest, respectively. If these folds indeed belong to the same regional $\mathrm{D}_{3}$ event, it is possible that the original $\mathrm{F}_{3}$ fold axes were subhorizontal and/or noncylindrical. Progressive shortening would then have rotated the fold axes towards vertical in the same direction as their initial (shallower) plunge.

Sillimanite pods consisting of variably sericitized fibrolite appear to follow $\mathrm{F}_{3}$ crenulations and parasitic folds (Figures 2d, 5a) and some strings of fibrolite align with $\mathrm{S}_{3}$ axial planes, suggesting at least some syn- $\mathrm{S}_{3}$ sillimanite growth. It is likely that the sillimanite also grew pre-to-syn- $S_{2}$, because pods are generally flattened parallel to the $S_{2}$ spaced foliation of alternating quartz- and mica-rich layers, or "Q\&M" domains (Bell and Rubenach, 1983) and at least part of the sillimanite pods must have been in place prior to $\mathrm{F}_{3}$ folding.

The general map pattern of the Mica Basin Area (Appendix B, Plate 1b) seems to represent a map-scale $F_{3}$ fold that has transposed $S_{0}-S_{1}-S_{2}$ into an east-west to northeast striking, subvertical orientation in its limbs. In the $\mathrm{F}_{3}$ hinge, the $\mathrm{S}_{0}-\mathrm{S}_{1}-\mathrm{S}_{2}$ composite foliation is subvertical and strikes generally north-south. I infer that the strike of $\mathrm{S}_{2}$ prior to $\mathrm{D}_{3}$ may have been roughly north-south; however, if $\mathrm{S}_{2}$ was shallowly dipping, as at Lester Mountain, it could have had a variety of orientations prior to $\mathrm{D}_{3}$. 


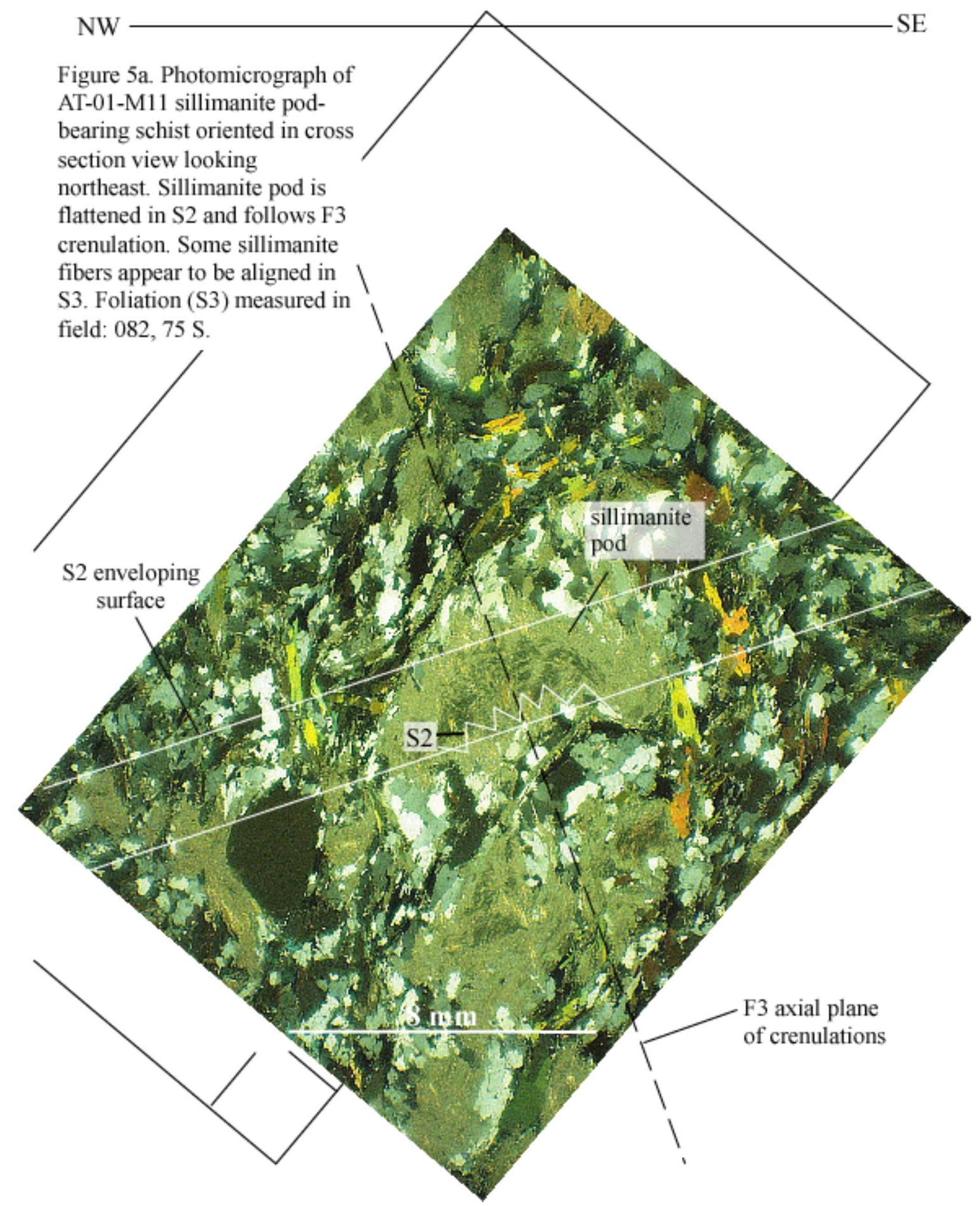




\section{S}

Figure 5b. Photomicrograph of K01-LM-23 staurolite schist oriented in cross sectional view looking west. Staurolite (st) preserves an $\mathrm{S} 1$ inclusion trail at high angles to both the spaced foliation of Q\&M domains (S2) and the counterclockwise transecting S3 fabric of aligned micas. S2 measured in field: $085,50 \mathrm{~S}$.

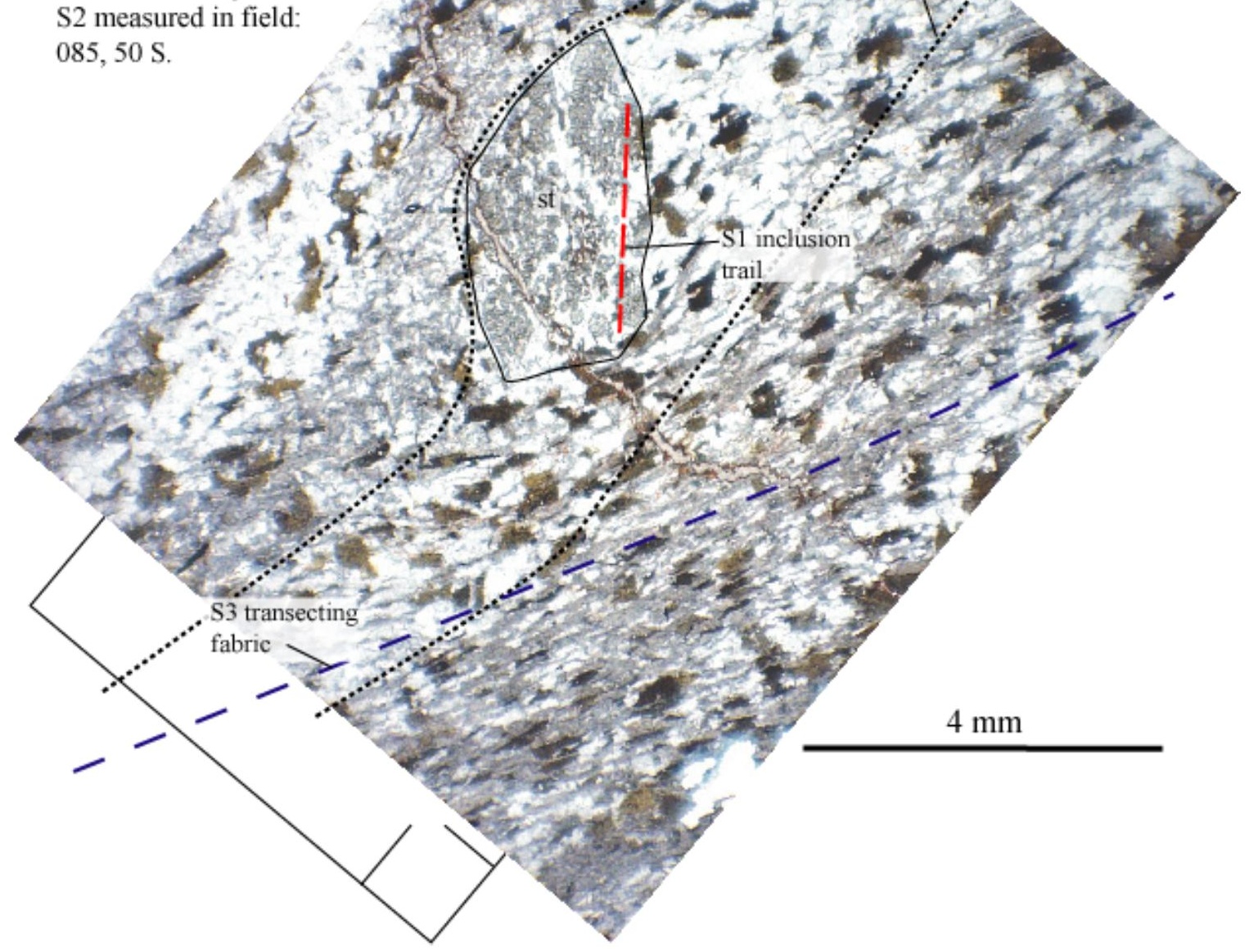




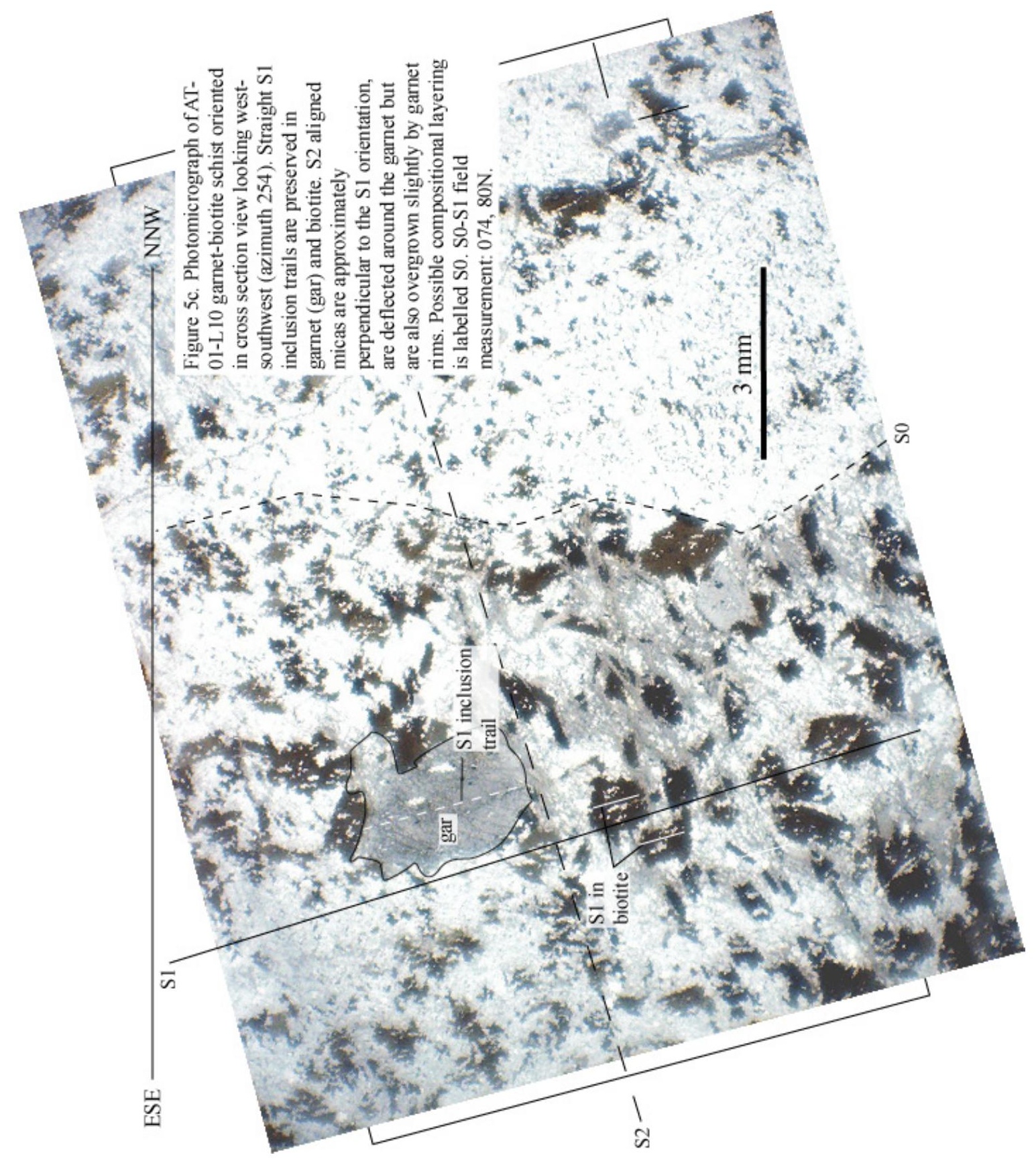




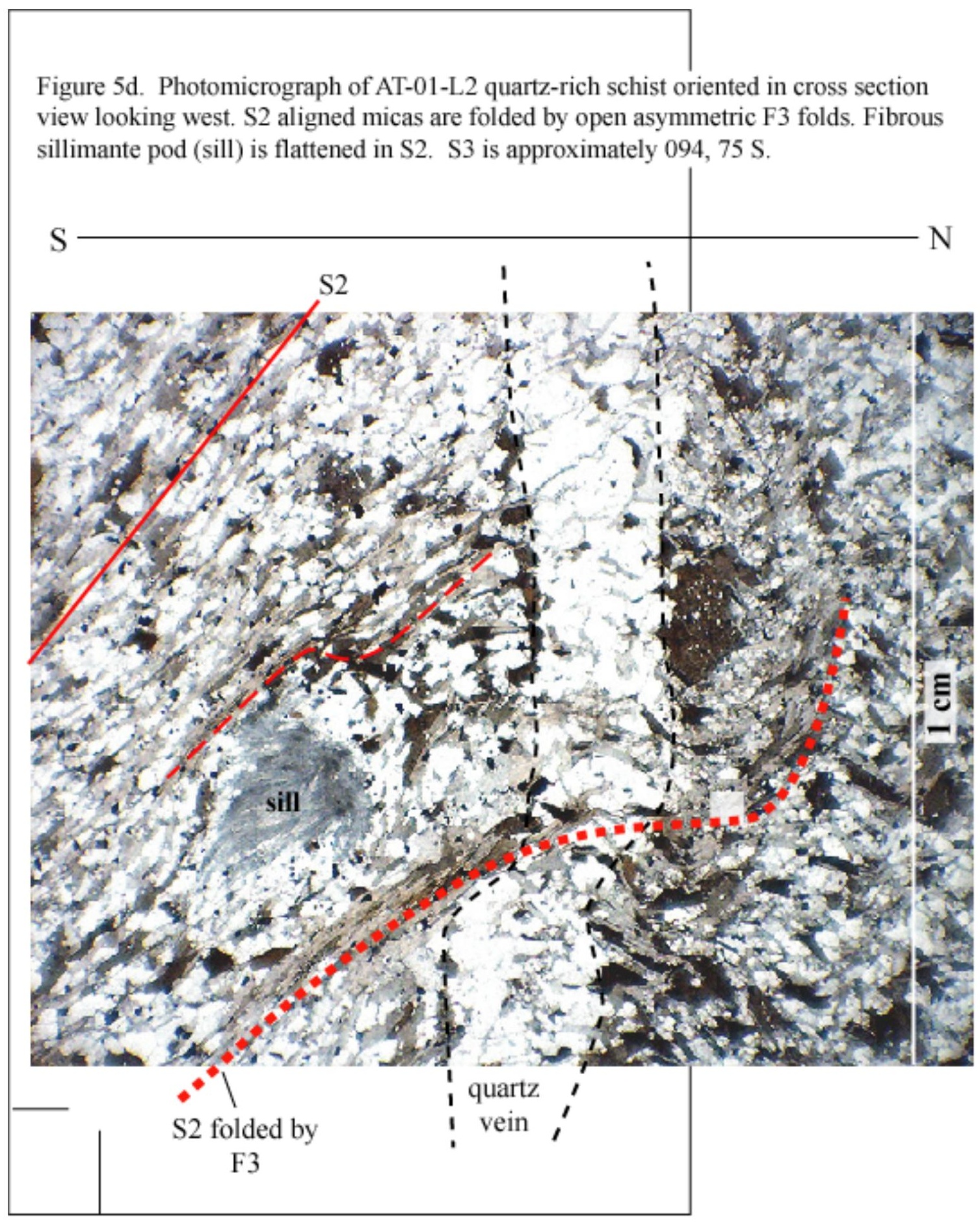


Figure 5e. Photomicrograph of AT-01-L3A quartz-mica schist oriented in cross section view looking southwest (to azimuth 230). S0-S1 orientation shown is based on observations of the hand sample in the field. S2 aligned micas are crenulated by F3. S2 measured in

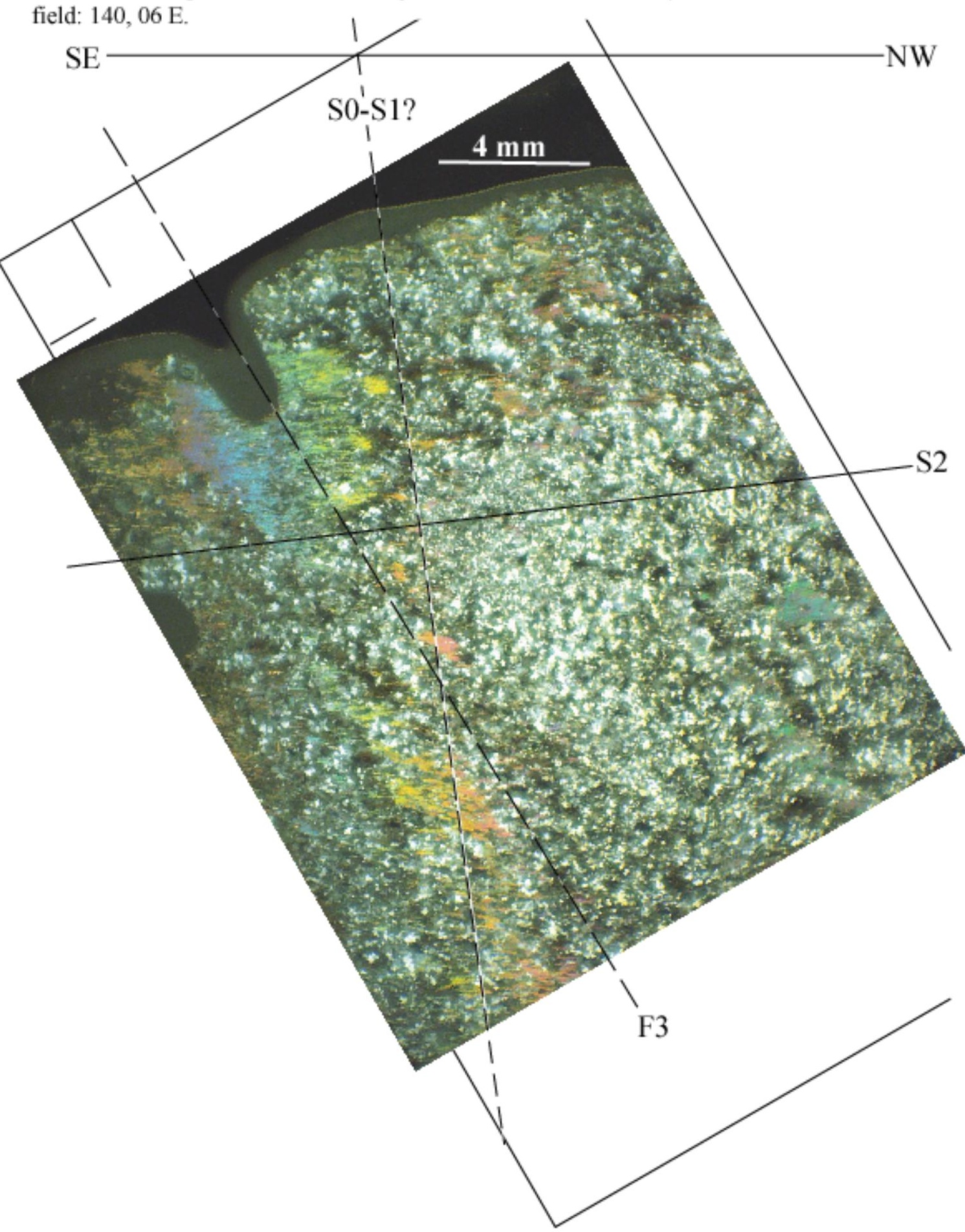




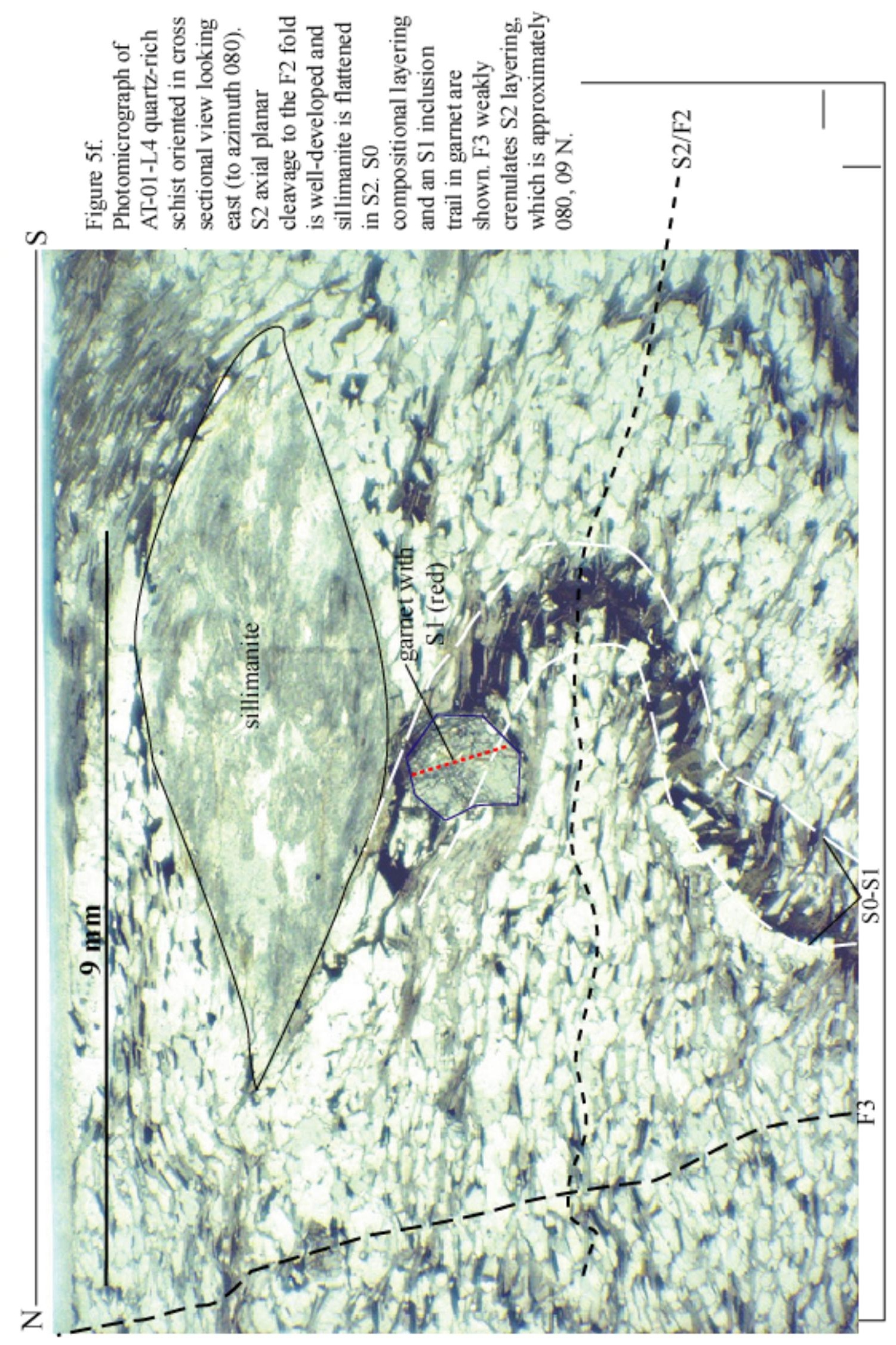




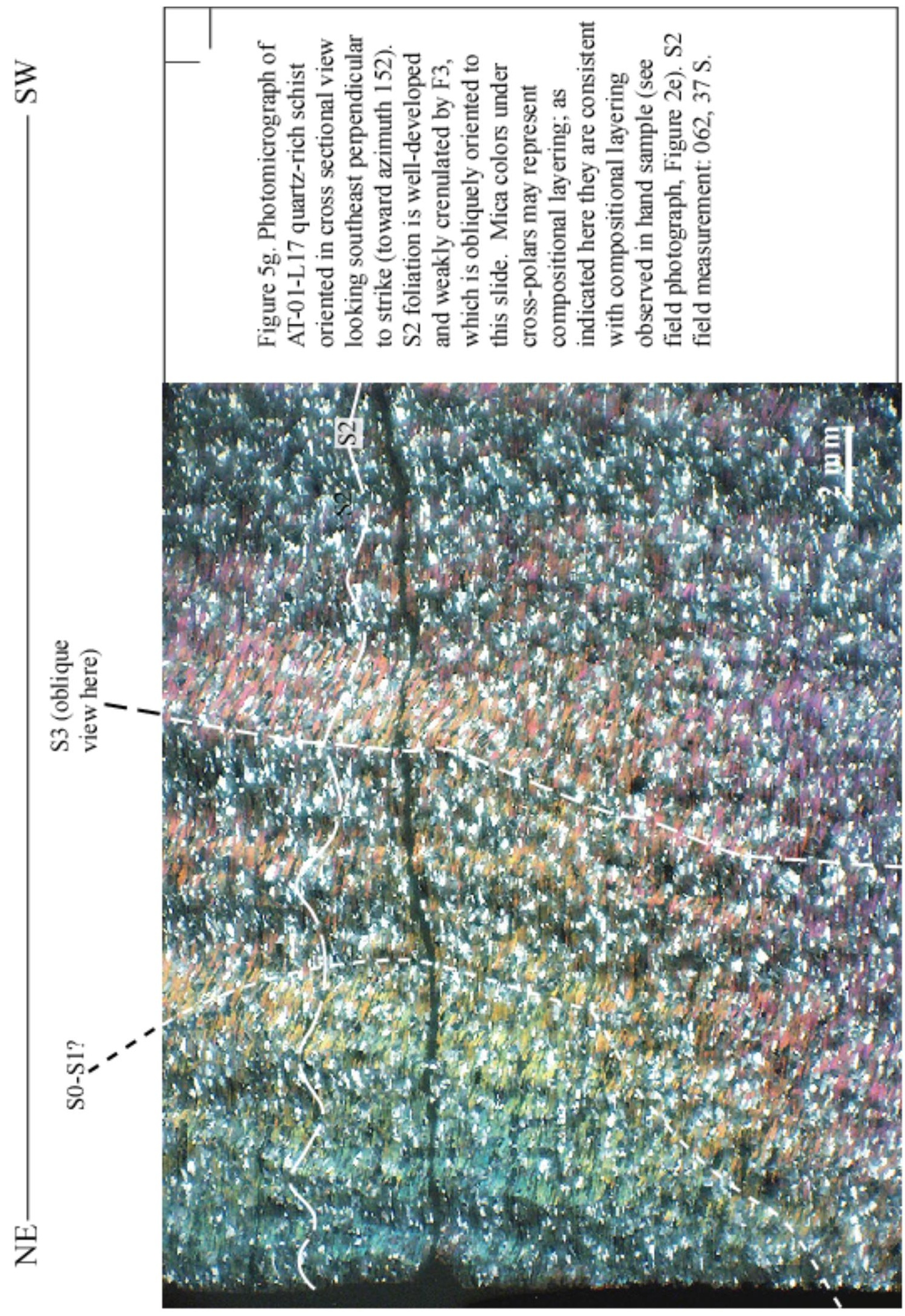




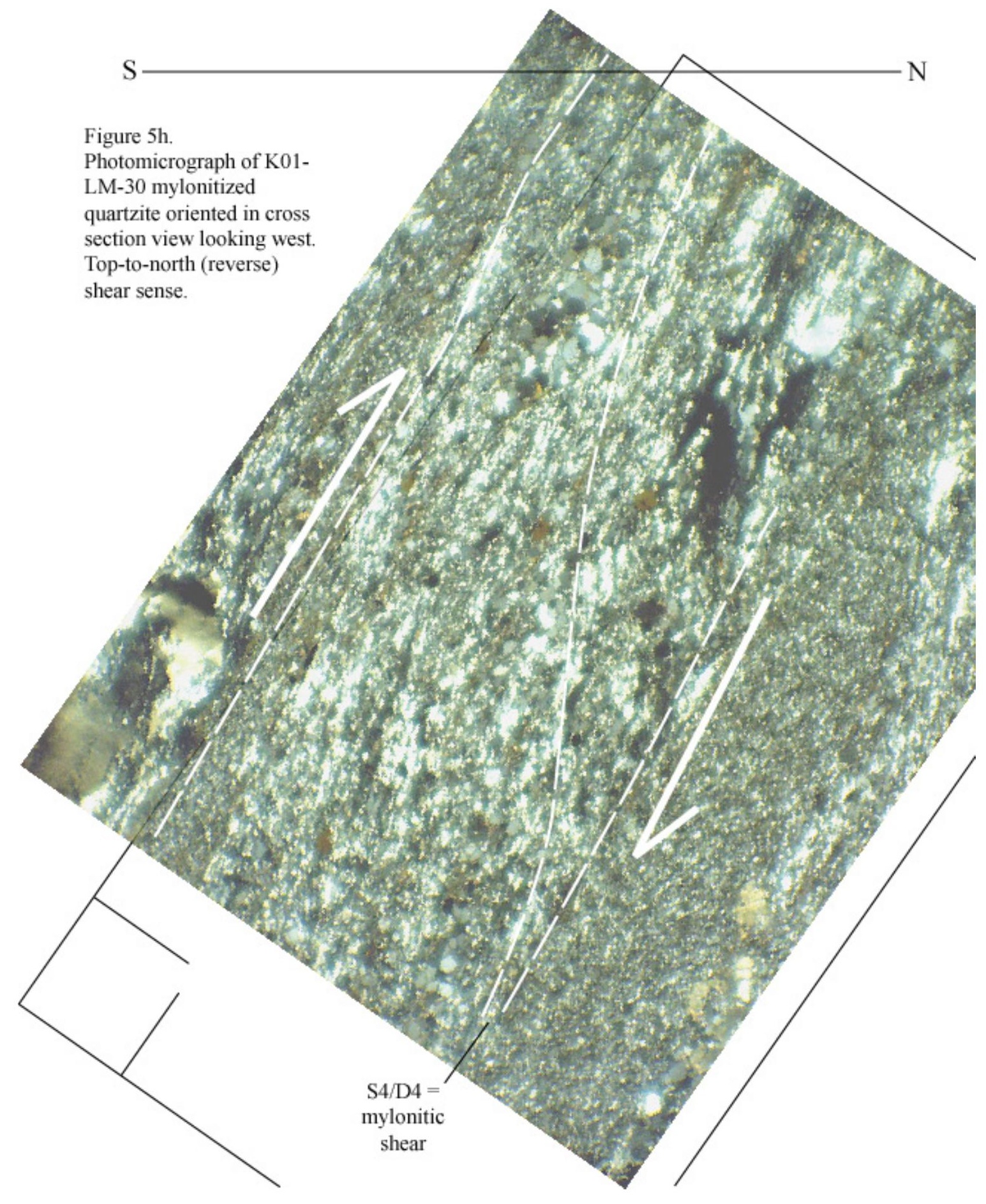

$-85-$ 


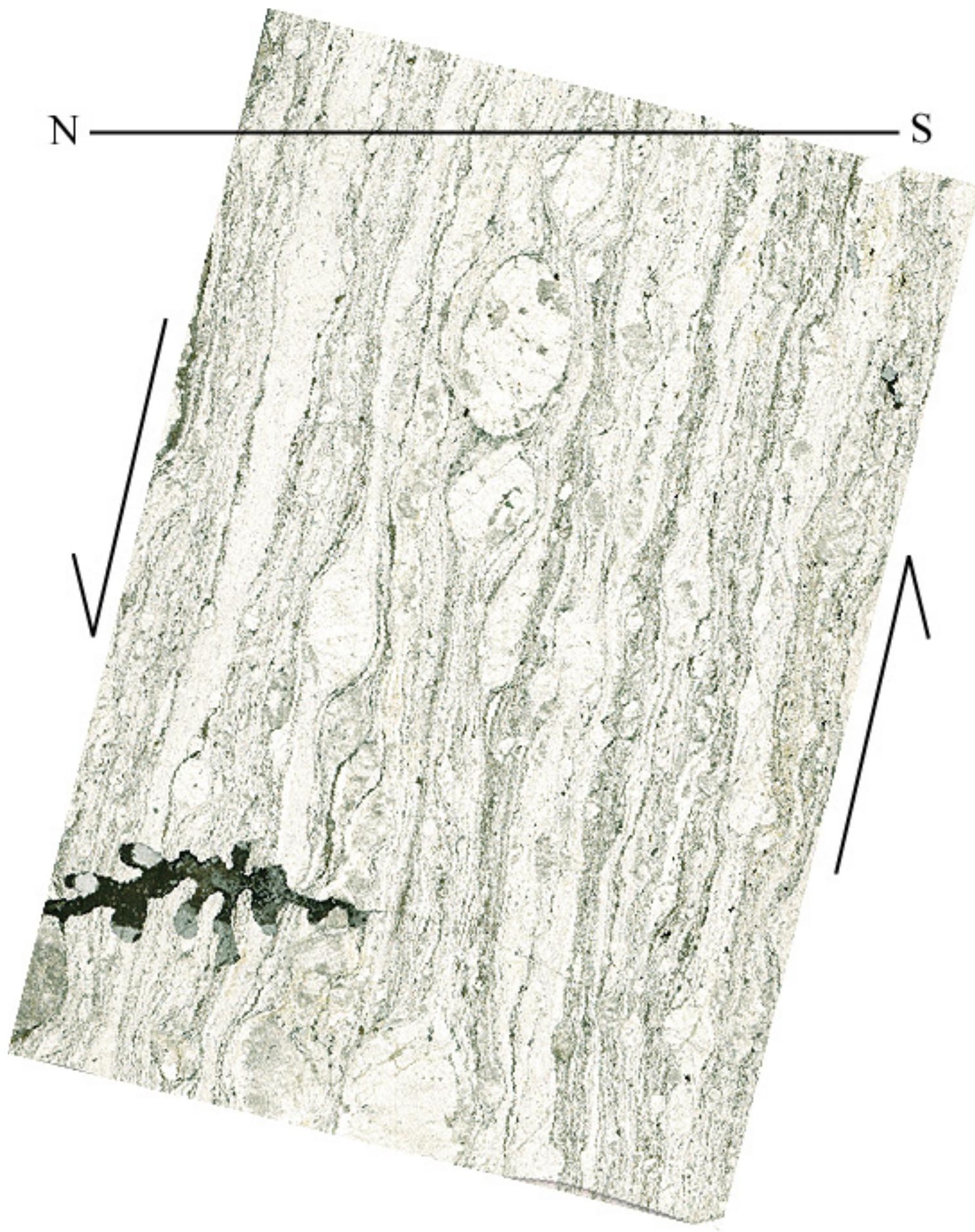

Figure 5i. Scan of entire thin section ( $26 \times 40 \mathrm{~mm}$ ) of K98-PK-22 mylonitized granite from the Soda Creek -- Fish Creek shear zone oriented in cross section view looking east to 080 . The mylonitic fabric is oriented $080,76 \mathrm{~N}$ and stretching lineation is $305 / 70$. Shear sense is north side down. 


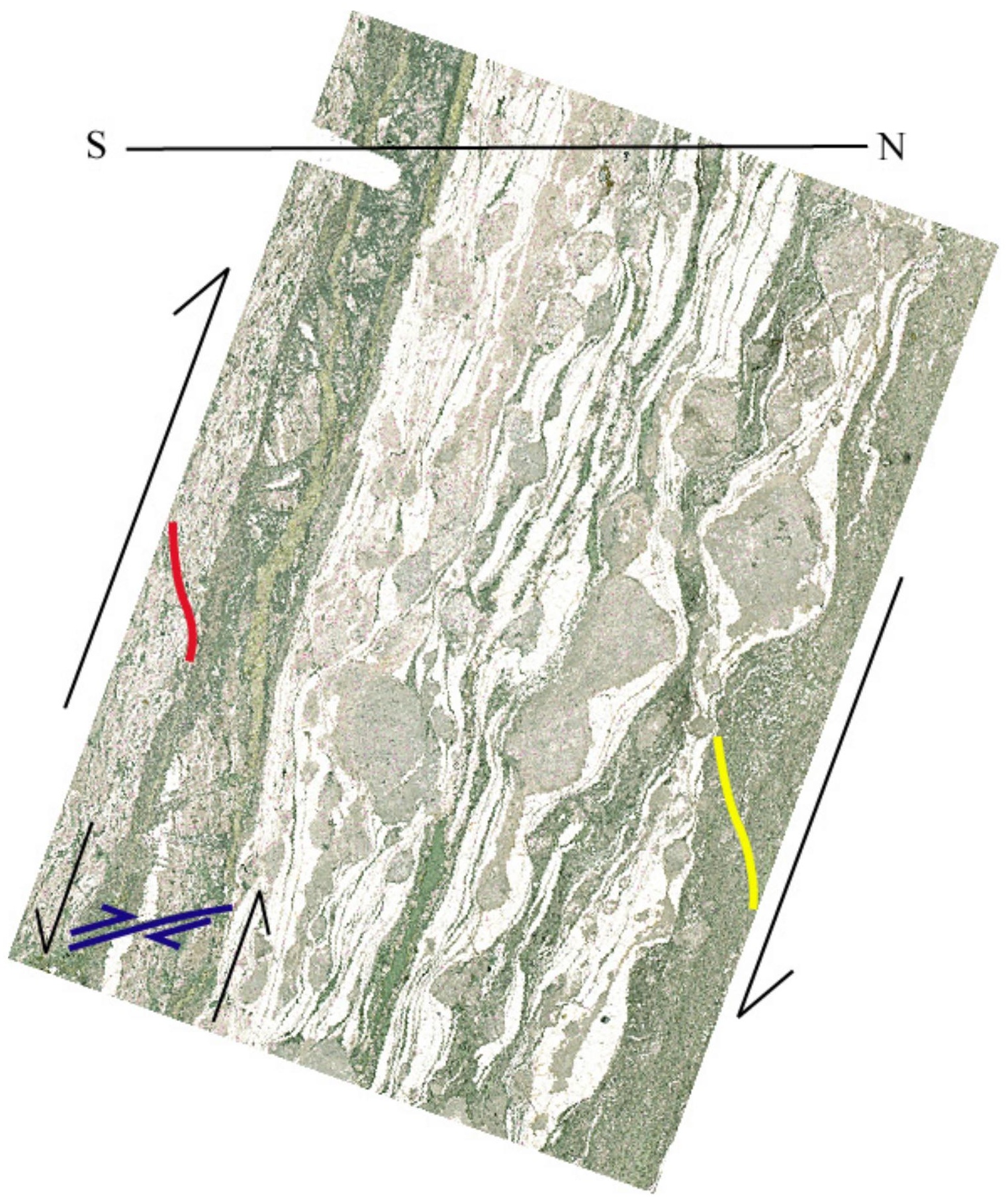

Figure $5 \mathrm{j}$. Scan of entire thin section ( $26 \times 40 \mathrm{~mm}$ ) of KPK-99-54 mylonitized gneiss from the Soda Creek -- Fish Creek shear zone oriented in cross section view looking west. Shows more brittle features then in Figure $5 \mathrm{i}$ and also chloritization. The mylonitic fabric is oriented $090,70 \mathrm{~S}$ and stretching lineation is $263 / 36$. Shear sense is south side up in mylonitic S-C fabric (yellow) and ultramylonitic S-C fabric (red). Antithetic fault (blue) in more brittle layer indicates the opposite shear sense (south side down). 


\section{SE}

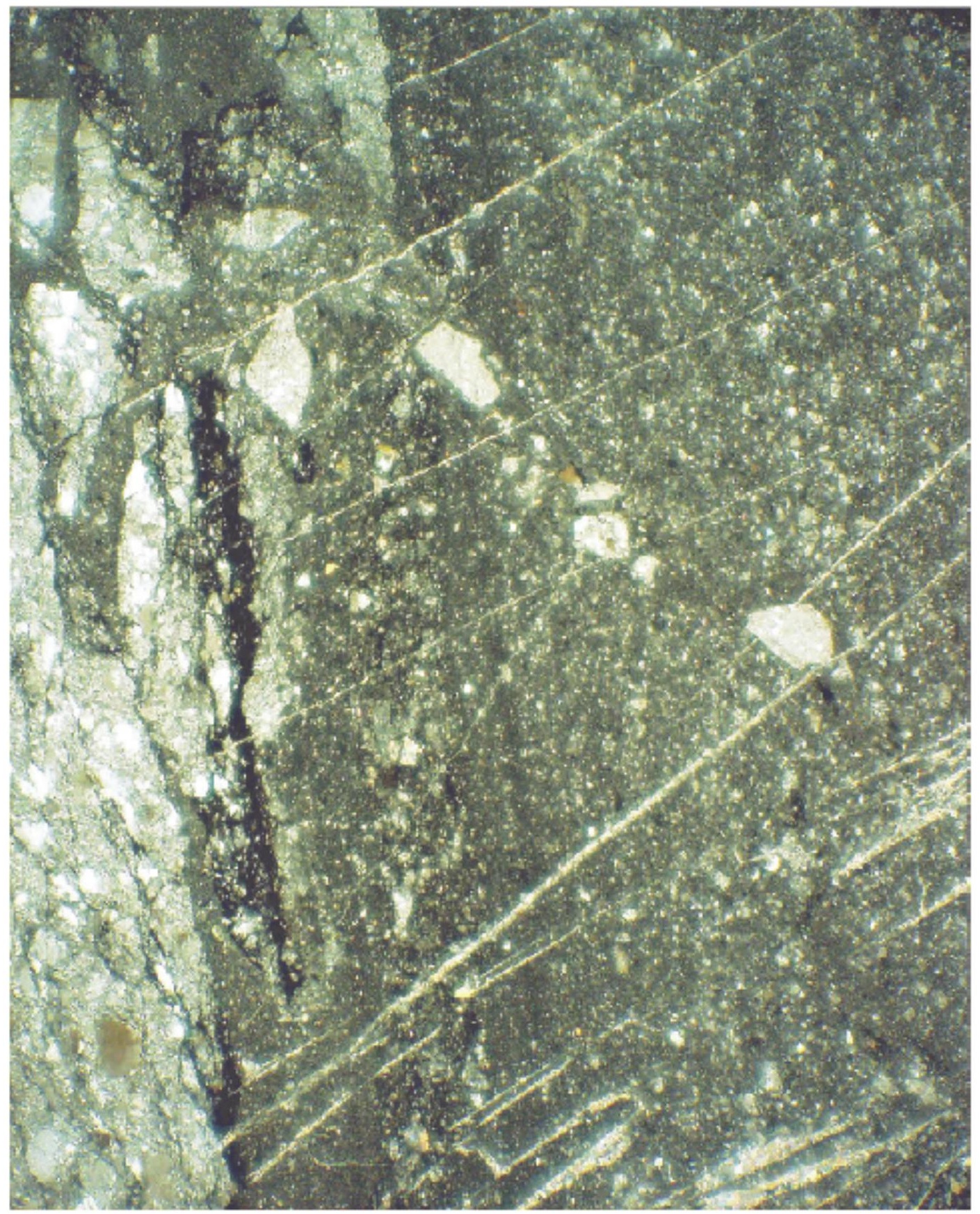

Figure 5k. Scan of entire thin section of K98-PK-20 $(26 \times 40 \mathrm{~mm})$ from a chloritized vein of pseudotachylyte in the Soda Creek -- Fish Creek shear zone oriented $045,76 \mathrm{~N}$ with a stretching lineation 230/06. Cross section view looking southwest to 235 . 


\section{LESTER MOUNTAIN: FOLDING OF QUARTZITE-SCHIST PACKAGE}

Detailed mapping of the quartzite-schist package has shown that deformation fabrics in the Lester Mountain area can be correlated to the fabrics in the Farwell Mountain and Mica Basin areas, but interestingly, early Lester Mountain fabrics have a different geometry. A kinematic history for the Lester Mountain area follows:

(1) $\mathrm{D}_{1}=$ isoclinal folding of schists and variable transposition of bedding $\left(\mathrm{S}_{0}\right)$ into an $\mathrm{S}_{1}$ tectonic fabric.

(2) $D_{2}=$ folding of the $S_{0}$ and $S_{1}$ fabrics into north-verging, recumbent $F_{2}$ isoclinal folds with an average fold axis orientation of $17^{\circ} \rightarrow 242^{\circ}$ (Figures 2e, 6a). The $S_{2}$ axial planar fabric (Figure 6b) is well-developed throughout the area, but its original orientation is thought to be best preserved in the hinges of open $F_{3}$ folds, where it dips shallowly to moderately southward.

(3) $D_{3}=$ folding of $S_{2}$ and earlier fabrics into open $F_{3}$ folds (Figure $2 f$ ); $S_{3}$ axial planar cleavage is most visible in staurolite schist and quartz-mica schist units. The average $\mathrm{S}_{3}$ orientation is $066^{\circ}, 76^{\circ} \mathrm{S}$ (Figure $6 \mathrm{c}$ ) and the average $\mathrm{F}_{3}$ fold axis orientation, based on a plot of poles to $S_{2}$, is $5^{\circ} \rightarrow 074^{\circ}$ (Figure 6b). 


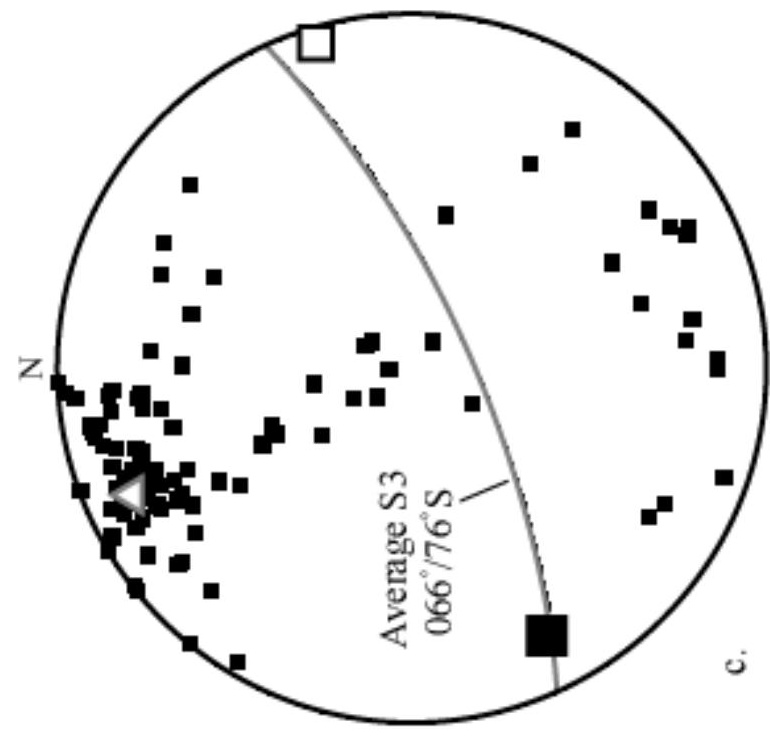

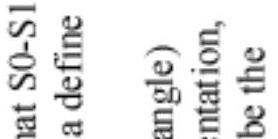

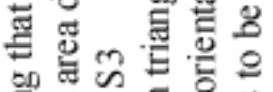

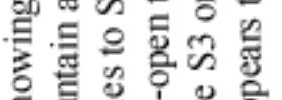

品产衣哭 言

.

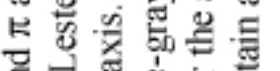

를을

흔 능 을

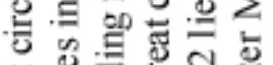

氜总的

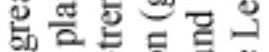

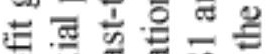

范芭焉的帚

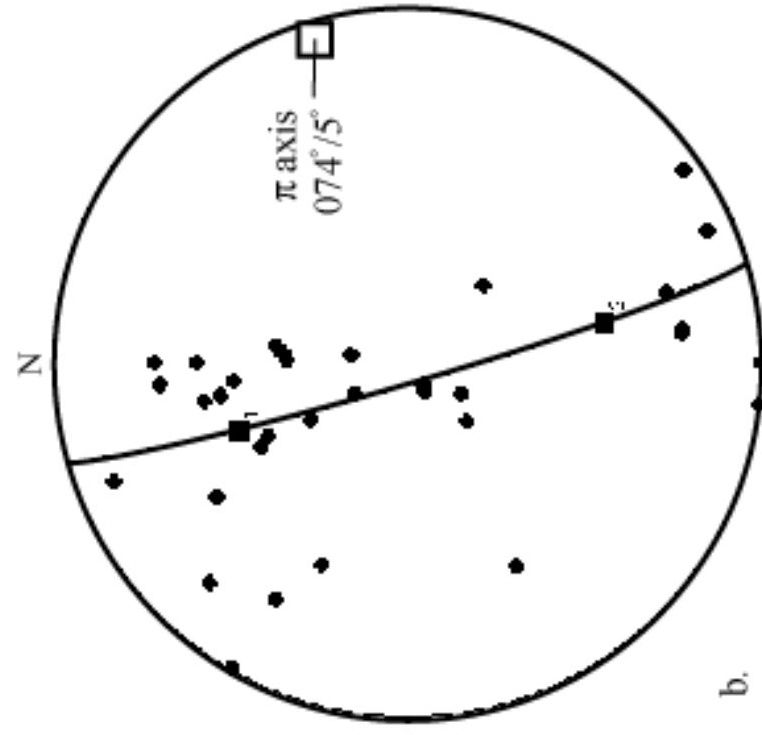

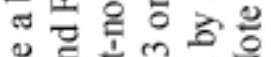

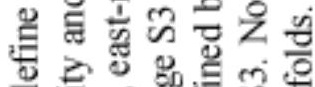

言- 然

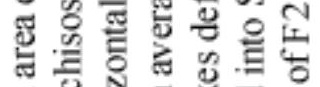

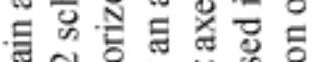

武

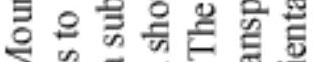

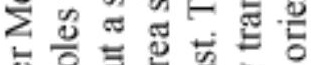

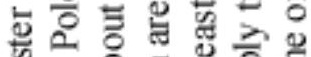

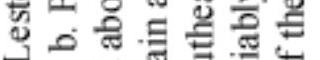

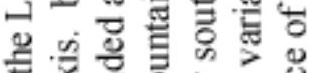

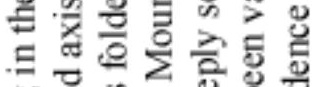

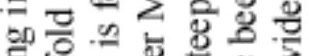

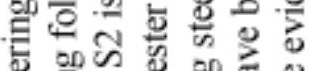

일 的可

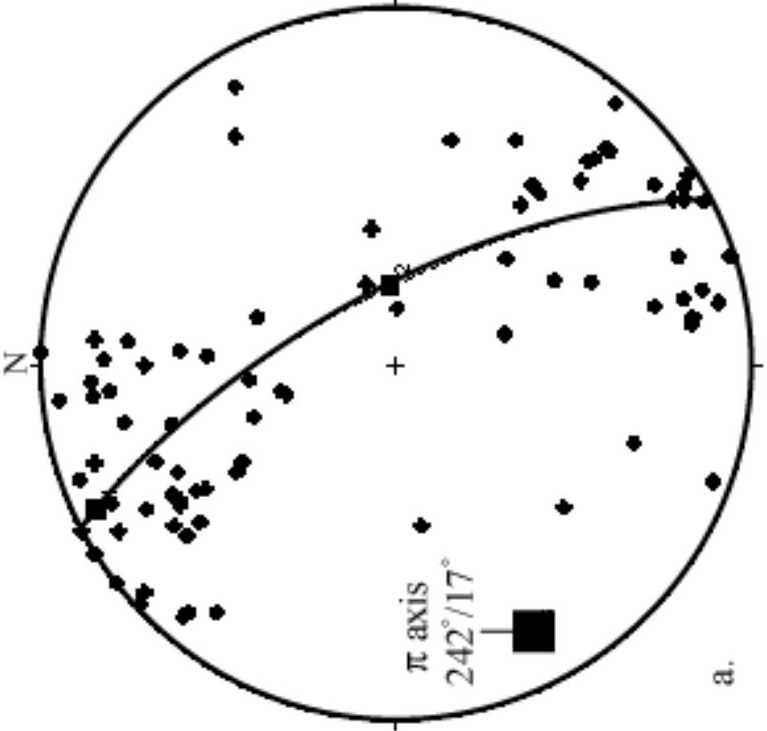

해를 응

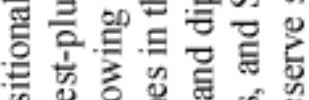

कू

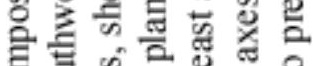

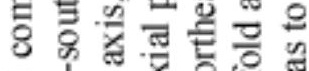

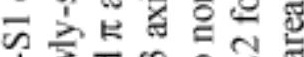

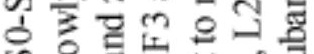

น

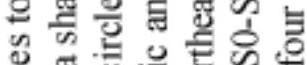

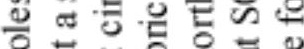

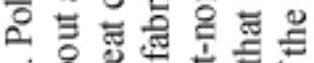

त $\frac{0}{0}$ 吅 on

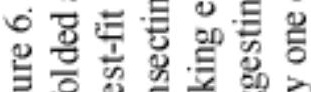

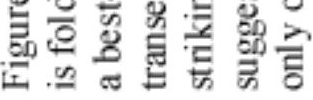


The $\mathrm{S}_{2}$ fabric in the Lester Mountain area is of particular interest because it is associated with a generation of north-vergent recumbent folds which may represent nappe folds in a ductile fold-and-thrust belt related to collision of the Rawah and Green Mountain blocks. It is thus important to note where the $\mathrm{S}_{2}$ fabric has not been completely transposed into $S_{3}$, as these locations give the best approximation of its original orientation. $\mathrm{S}_{2}$ is variably folded and crenulated by the open $\mathrm{F}_{3}$ folds. The northeaststriking, steeply-SE-dipping $\mathrm{S}_{3}$ axial planar fabric is best developed in the more micaceous units, where it transects $\mathrm{S}_{0}, \mathrm{~S}_{1}$, and $\mathrm{S}_{2} / \mathrm{F}_{2}$ (Figure $5 \mathrm{~b}$ ). In schists on Lester Mountain and the next ridge to the east, the $\mathrm{S}_{2}$ foliation is a schistose layering that is subhorizontal to moderately-dipping, oriented at high angles to $\mathrm{S}_{0}-\mathrm{S}_{1}$, and weakly crenulated by $\mathrm{F}_{3}$ (see Figures $5 \mathrm{~b}-\mathrm{g}$ ). The $\mathrm{S}_{2}$ fabric in many places is the dominant tectonic layering, defined in thin section as a spaced foliation of alternating quartz and mica domains with porphyroblasts preserving $\mathrm{S}_{1}$ inclusion trails (Figure $5 \mathrm{~b}, \mathrm{c}, \mathrm{f}$ ).

In several of the Lester Mountain schist samples, $\mathrm{S}_{0}$ through $\mathrm{S}_{3}$ are visible when hand sample and thin section observations are combined (Figures 5b-g). Also, a sample (K98-PK-27a) of quartz-rich mica schist from Willow Creek Canyon, which contains multiple fabrics, has been selected for monazite dating. Its microstructures are discussed in Appendix E.

The timing of metamorphic mineral growth relative to structural fabrics is inferred from porphyroblast-matrix relationships (see Table 4). There appears to have been garnet, biotite, staurolite, and white mica growth syn-to-post- $\mathrm{S}_{1}$, as these minerals preserve $\mathrm{S}_{1}$ inclusions and some deflect $\mathrm{S}_{2}$ micas (Figure $5 \mathrm{~b}$ ). Sillimanite, staurolite, 
biotite, and white micas may have also grown syn- $\mathrm{S}_{2}$; although there is little evidence of folded $\mathrm{S}_{1}$ inclusion trails to confirm this. Sillimanite pods may have also grown pre-tosyn- $\mathrm{S}_{3}$, as they are evidently reoriented by $\mathrm{F}_{3}$ (Figure $5 \mathrm{c}$ ) but some fibers appear to align in the $S_{3}$ axial plane.

Mylonitized $\left(\mathrm{D}_{4}\right)$ quartzite has been observed on Lester Mountain (Figure 5h) the mylonitic fabric is oriented 270, $55 \mathrm{~S}$ and preserves top-to-the-north (reverse) shear sense.

\section{SODA CREEK-FISH CREEK SHEAR ZONE}

Based on the kinematic sequences in the other three field areas, the regional mylonitic shearing event in the Park Range is considered to be $\mathrm{D}_{4}$. The following section presents an independent kinematic history for the Soda Creek - Fish Creek shear zone, then places it into a regional context by correlating the mylonitic event to the regional $\mathrm{D}_{4}$ and by designating the regional east- to northeast-striking, subvertical foliation as the regional $\mathrm{S}_{3}$. It is then possible to tentatively correlate the age constraints on fabrics in the shear zone to fabrics in the other three field areas (Table 3).

(1) $\mathrm{D}_{1}=$ development of an $\mathrm{S}_{1}$ tectonic fabric in the ca. $1746 \mathrm{Ma}$ (Premo and Van Schmus, 1989) Buffalo Pass granite (Xb). Supracrustal gneisses and schists contain a foliation $\left(\mathrm{S}_{0}\right)$ that pre-dates the intrusion of the Buffalo Pass pluton and is inferred to be originally subhorizontal bedding. This $\mathrm{S}_{0}$ layering is isoclinally folded by $F_{1}$ folds with axial planes parallel to the $S_{1}$ foliation in the granite. The original orientation of $\mathrm{S}_{1}$ is unknown but is inferred to have been northweststriking and shallowly dipping. The age of the granite and a 1730 Ma late-stage 
pegmatite dike with a weak $S_{1}$ fabric constrain $S_{1} / D_{1}$ in the shear zone to 1.746$1.73 \mathrm{Ga}$ (Chamberlain, unpublished data).

(2) $\mathrm{D}_{2}=$ folding of $\mathrm{S}_{1}$ into a subvertical, northeast-trending $\mathrm{S}_{2}$ fabric with an average orientation of $079^{\circ}, 81^{\circ} \mathrm{S}$ and a fold axis oriented $70^{\circ} \rightarrow 347^{\circ}$ (Figure $7 \mathrm{a}, \mathrm{b}$ ). Along the limbs of small-scale $\mathrm{F}_{2}$ folds are melt-filled shear bands oriented in $\mathrm{S}_{2}$ (Figure $2 \mathrm{~g}$ ). A hornblende-pegmatite dike that crosscuts $S_{1}$ and is folded by $F_{2}$ is interpreted to be early-syn- $\mathrm{S}_{2}$ and yields a $\mathrm{U}-\mathrm{Pb}$ date of $1.68 \mathrm{Ga}$ (Appendix A, Table 1). For the purpose of regional correlation, this generation will be referred to as the regional $\mathrm{D}_{3}$, on the basis of the consistent open fold style and east- to northeast-striking, steeply-dipping to subvertical axial planes (compare Figures $3 b, 4 c, 6 c, 7 b)$. Thus, the 1.68 Ga date is tentatively applied to the $S_{3}$ fabrics in the other field areas (Table 3).

(3) $\mathrm{D}_{3}=$ regional $\mathrm{D}_{4}=$ mylonitic shear bands crosscut the earlier, higher-temperature fabrics. Anastomosing strands of mylonites [Appendix C, Plate 7 (Snyder, 1980); Figures $2 \mathrm{~h}, 5 \mathrm{i}, \mathrm{j}]$ weave through the shear zone with an average orientation of $232^{\circ}, 80^{\circ} \mathrm{N}$ (Figure $7 \mathrm{c}$ ), displaying a mutually crosscutting relationship with mafic dikes associated with emplacement of the ca. $1.42 \mathrm{Ga}$ Mount Ethel pluton (Foster et al., 1999; Barinek et al., 1999). Snyder (1980) assigned a left-lateral strike-slip shear sense to the mylonite zone based on offset dikes; in contrast, Barinek et al. (1999) reported dominantly north-side-down dip-slip shear sense indicators. This north-side-down shear sense contrasts with the expected northside-up motion based on evidence for synkinematic emplacement of the Mt. Ethel pluton at the northern margin of the shear zone. Field relations suggest that 
-94- 


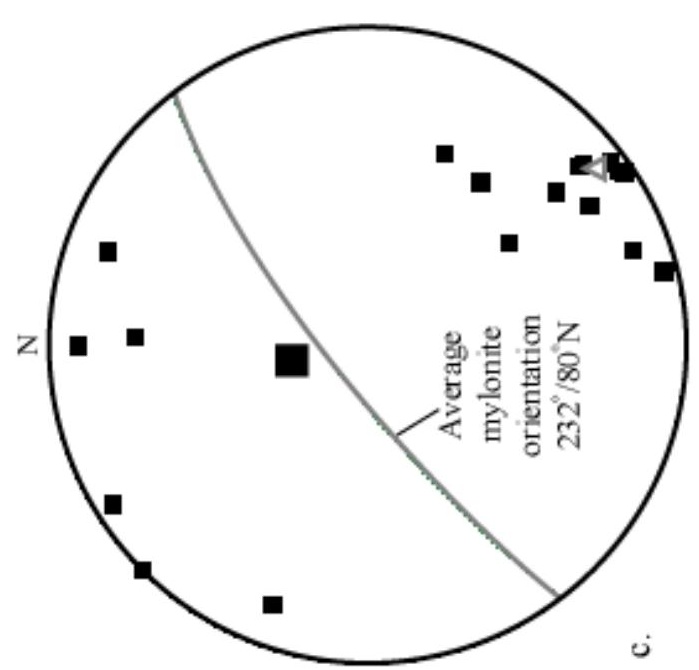

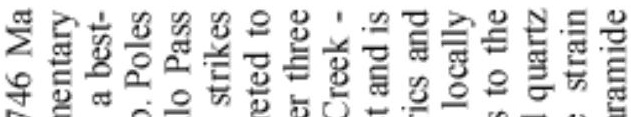

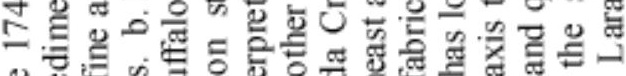

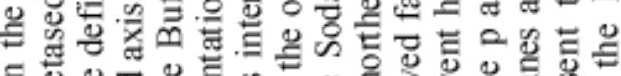

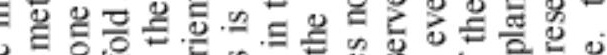

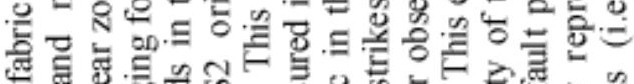

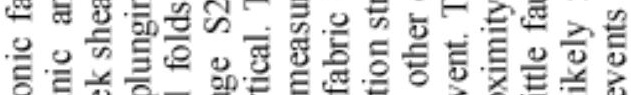

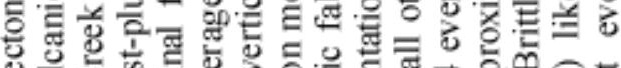

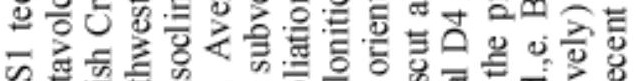

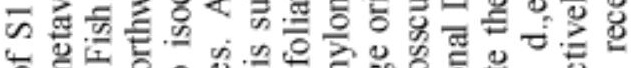

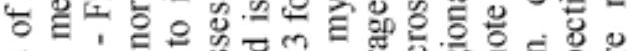

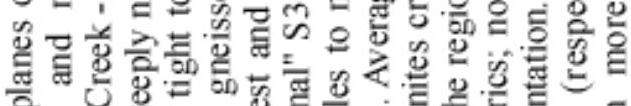

등

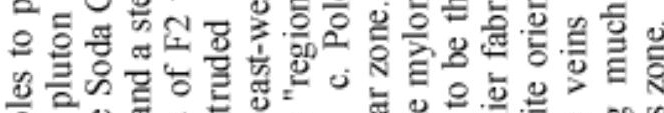

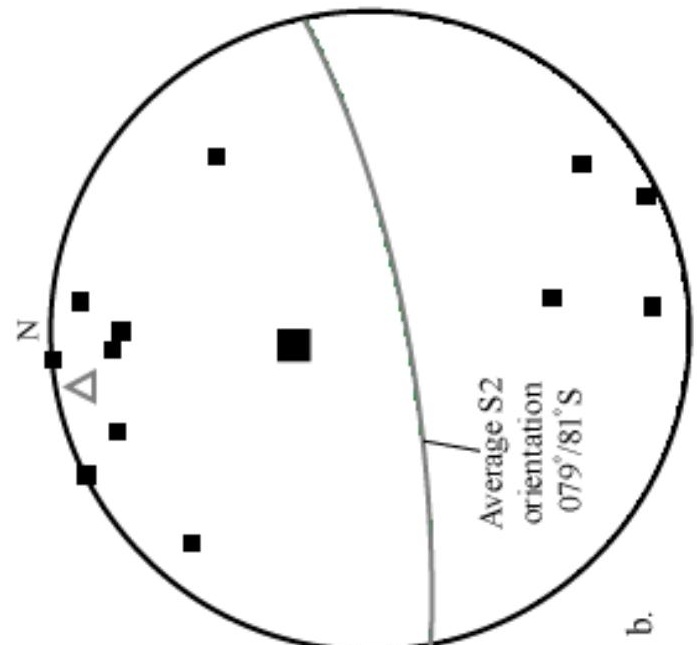

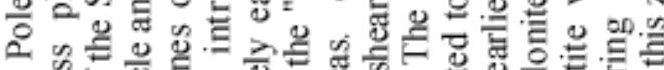

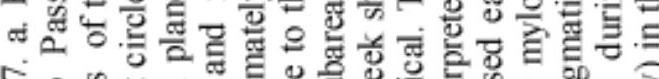

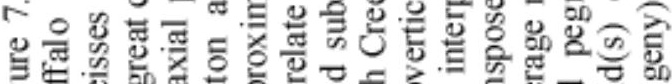

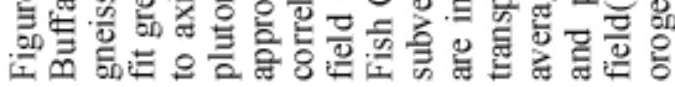
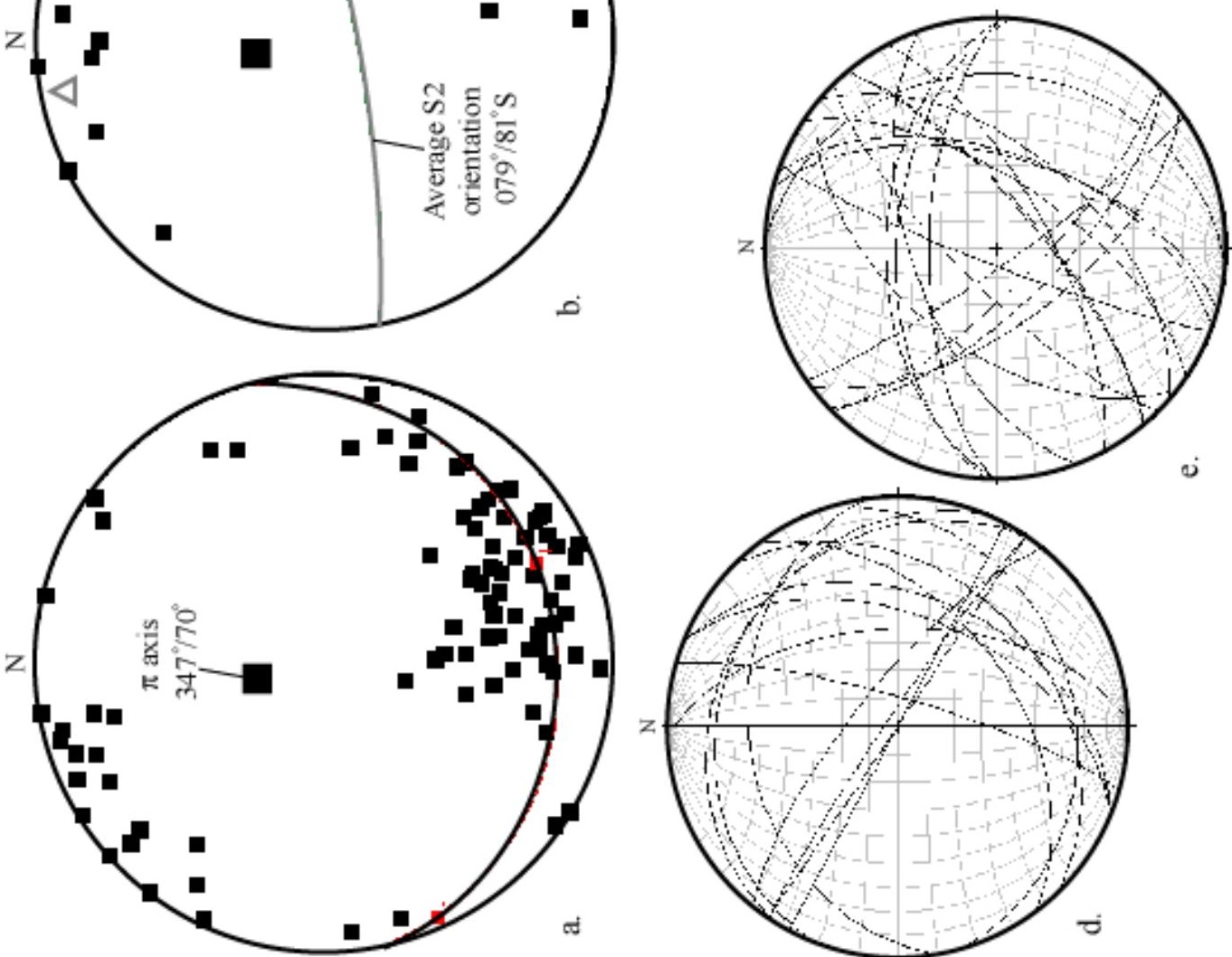


\section{DISCUSSION}

Figures 1a-d are working hypotheses that combine the available structural, metamorphic, and timing data in the form of P-T-t-D paths. Constraints on the P-T points come directly from studies by previous workers (discussed in Appendix A). Rocks from current exposures in all four field areas have inferred clockwise P-T paths, which represent burial to mid-crustal depths, subsequent heating, and gradual exhumation. This interpretation is based largely on the well-constrained clockwise shape of the Lester Mountain area P-T path (White, 1987). The P-T-t-D paths are constructed by supplementing the P-T paths with schematic sketches that show the absolute ages and relationships between structural and metamorphic fabrics. Deformation sketches are hypothesized to plot somewhere on the P-T path; dots are placed where these correlations are best constrained. The following discussion describes these hypothesized paths and their implications for the tectonic history of each field area.

Both the Farwell Mountain and Mica Basin areas (Figure 1a, b) show evidence for a $\mathrm{D}_{1}$ isoclinal folding event prior to $1.74 \mathrm{Ga}$. Farwell Mountain rocks were isoclinally folded again during $\mathrm{D}_{2}$ ca. $1.74 \mathrm{Ga}$, then overprinted weakly by $\mathrm{D}_{3}$ fabrics ca. $1.68 \mathrm{Ga}$, never exceeding $500^{\circ} \mathrm{C}$ or $7 \mathrm{kbar} . \mathrm{D}_{4}$ mylonitization ca. 1.42 Ga presumably occurred in the brittle-ductile transition zone, at a pressure somewhere around 3 kbar. In Mica Basin, the maximum temperature and pressure were reached during $\mathrm{D}_{2}$ ca. $1.74 \mathrm{Ga}$; this may also be the timing of the major sillimanite pod growth. During $\mathrm{D}_{2}$ shortening and constrictional strain, $\mathrm{F}_{2}$ refolded folds developed. Ca. $1.68 \mathrm{Ga}, \mathrm{D}_{3}$ refolded $\mathrm{S}_{2} / \mathrm{F}_{2}$ and the earlier fabrics. We speculate that $\mathrm{D}_{3}$ was a progressive deformation that persisted or 
occurred in several pulses $1.68-1.60 \mathrm{Ga}^{3}$, tightening the $\mathrm{S}_{3}$ fabric while Mica Basin rocks remained at high temperatures. Some sillimanite pod growth may have occurred during $\mathrm{D}_{3}$ as well.

The Farwell Mountain area P-T path has not been well constrained, but it has a maximum temperature $\leq 500^{\circ} \mathrm{C}$ at middle-crustal pressures, much cooler than the maximum temperature of $>750^{\circ} \mathrm{C}$ recorded in Mica Basin rocks (Appendix A, Figure 3). If we are correct in considering the intrusive rocks in the Mica Basin area to be part of the Elkhorn Mountain/Seven Lakes plutonic complex (pending geochronologic results), then Mica Basin rocks were lithologically part of the Green Mountain block. The similarities in kinematic history and fabric orientation between the Farwell Mountain and Mica Basin exposures is consistent with both areas being part of the Green Mountain block. Perhaps the Mica Basin exposure represents a deeper slice of this northern block; the maximum temperature reported by Smith (1990) was at a pressure $>7 \mathrm{kbar}$, higher than most pressures calculated for Proterozoic Park Range rocks. This seems to contradict the map (Plate 1a); however, it is possible that this steeply-fault-bounded Laramide block uplift is actually exposing a piece of the northern block that has been buried beneath a shallowly south-dipping boundary since the time of assembly.

The disparity in the P-T-t-D paths and deformation styles between the Farwell Mountain and Mica Basin areas might also indicate a history of strain partitioning during collision. For example, both areas have evidence for constrictional strain during $D_{1} / D_{2}$, but strongly refolded and closed folds appear only in the Mica Basin area. The Mica

\footnotetext{
${ }^{3}$ Based on geochronologic work by Chamberlain (unpublished data): (1) dates of metamorphic sphene growth at $\sim 1680$ and $\sim 1600$ Ma in the Soda Creek - Fish Creek shear zone and (2) 1680 Ma U-Pb zircon date for a syn- $\mathrm{S}_{2}$ hornblende-pegmatite dike in the Soda Creek - Fish Creek shear zone, here correlated with the $\mathrm{S}_{3}$ generation in the Farwell Mountain, Mica Basin, and Lester Mountain areas.
} 
Basin rocks may have been relatively weak due to their greater depth, lack of a large gabbroic body as on Farwell Mountain, and/or proximity to syn-collisional intrusive activity at depth.

The Lester Mountain P-T-t-D path (Figure 1c) has been well-constrained by White (1987). $\mathrm{D}_{1}$ occurred prior to $1.74 \mathrm{Ga}$ and involved burial to $\sim 500^{\circ} \mathrm{C}$ and $>5 \mathrm{kbar}$, isoclinal folding of bedding (possibly ductile nappes and thrust imbrication), and growth of kyanite, staurolite, and garnet. Maximum temperature $\left(\sim 600^{\circ} \mathrm{C}\right)$ was reached ca. 1.74 Ga during $\mathrm{D}_{2}$ at $>5$ kbar pressure; garnet rims, new garnets, and sillimanite pods grew during this time. One possible interpretation that is explored in this study is that a northverging fold and thrust belt produced isoclinal, recumbent folds in a broad middle-crustal zone of tectonic imbrication.

$\mathrm{D}_{3}$ in the Lester Mountain area is also interpreted to be a progressive event that occurred continuously or in pulses $1.68-1.60 \mathrm{Ga}$ while the rocks remained at temperatures $500-600^{\circ} \mathrm{C}$. Open folding largely reoriented earlier fabrics, and the associated shortening caused the rotation of lineations toward vertical. Additional sillimanite pod and garnet rim growth may have occurred during this time. Ca. $1.4 \mathrm{Ga}$, mylonitic shear fabrics cut through various parts of the region. Retrograde metamorphism, most obviously chloritization, is inferred to have occurred at this time when the Mount Ethel pluton was intruding and there was opportunity for heating and fluid flux along pre-existing structures.

The earliest event preserved in the Soda Creek - Fish Creek shear zone (Figure 1d) is the $\mathrm{D}_{1}$ (Regional $\mathrm{D}_{2}$ ), ca. 1.746-1.73 Ga during which the Buffalo Pass granite intruded and developed a tectonic fabric and the gneissic country rock was folded into 
isoclinal, possibly shallowly-dipping recumbent folds. $\mathrm{D}_{1}$ is inferred to have occurred when these rocks were at approximately $600^{\circ} \mathrm{C}, 5 \mathrm{kbar}$. Ca. $1.68 \mathrm{Ga}, \mathrm{D}_{2} / \mathrm{M}_{2 \mathrm{a}}$ involved the refolding of earlier fabrics, development of $\mathrm{S}_{2}$ melt-filled shear bands, and a generation of garnet and sphene growth. $\mathrm{M}_{2 \mathrm{a}}$ is inferred to represent some point on the P-T path that is approaching the maximum temperature at a pressure $\sim 5 \mathrm{kbar} . \mathrm{D}_{2} / \mathrm{M}_{2 \mathrm{~b}}$, ca. $1.60 \mathrm{Ga}$, was a second pulse of sphene and garnet growth while the rocks remained at temperatures $>\sim$ $540^{\circ} \mathrm{C}$; continued shortening may have tightened the $\mathrm{S}_{2}$ fabrics during this time.

Mylonitic shear during $\mathrm{D}_{3}$ (Regional $\mathrm{D}_{4}$ ) occurred ca. $1.42 \mathrm{Ga}$, presumably when the rocks were deep enough to be intruded by the Mount Ethel pluton and somewhere in the brittle-ductile transition zone, $\sim 3-4 \mathrm{kbar}$. This time was probably also characterizied by retrograde metamorphism (e.g. chloritization of biotite and pseudotachylyte) and fluid flux through the shear zone. Strong post-1.73 Ga overprinting in the shear zone makes it difficult to interpret its earliest tectonic history; this concept is discussed further in the Introduction. The nature of this shear zone certainly does not preclude the possibility that the Soda Creek - Fish Creek shear zone rocks were once part of a broad collisional "suture zone" and have since developed into a concentrated high-strain zone.

In conclusion, the combined P-T-t-D paths are used to form a working hypothesis for the deformational and metamorphic history of all four areas. The Farwell Mountain and Mica Basin areas are interpreted to be tectonic slivers of the northern (Green Mountain) block in the "Farwell Mountain - Lester Mountain suture zone". This is consistent with their inferred clockwise P-T paths, similarities in structural geometry, and differences in strain and maximum temperatures and pressures. The Lester Mountain area is interpreted to be a series of tectonic slivers of the southern (Rawah) block and 
accretionary wedge in the "Farwell Mountain - Lester Mountain suture zone". This is consistent with observed map patterns and structural geometries, with the P-T path previously constructed by White (1987) and with interpretations of clockwise looping PT paths in other areas of the southwestern U.S. (Williams and Karlstrom, 1996). The role of the Soda Creek - Fish Creek shear zone in the development of the suture zone remains enigmatic. The Buffalo Pass may be a syn-collisional pluton; the schists and gneisses may have been folded into thrust nappes in a pattern similar to that preserved in the Lester Mountain area. However, subsequent events in the Soda Creek - Fish Creek shear zone have almost obliterated all evidence of the pre-1.68 Ga fabrics and thus make it very difficult to make solid inferences about accretionary structures in the shear zone. 
Table 1. Descriptions of thin sections from samples collected during the 2000-2001 field seasons. Refer to Appendix C for sample list (Table 1) and sample location maps (Plates 3-7) for rock types and locations. Q---quartz; ksp---potassium feldspar; plag---plagioclase feldspar; fsp---feldspar; chl--chlorite; hbl---hornblende; bio---biotite; gar---garnet; st---staurolite; sill---fibrous sillimanite. Quartz and feldspar dynamic recrystallization texture regimes based on Hirth and Tullis (1992) and Tullis and Yund (1985).

\begin{tabular}{|c|c|c|}
\hline Sample ID & Assemblage & Remarks (fabrics and porphyroclasts/blasts) \\
\hline \multicolumn{3}{|c|}{ Farwell Mountain area } \\
\hline AT-01-FM-1 & $\begin{array}{l}\text { Hbl, carbonate, resorbed } \\
\text { gar, Mg-chl, Q, plag }\end{array}$ & \\
\hline \multicolumn{3}{|c|}{ Mica Basin area } \\
\hline AT-01-M1 & Gar, bio, hbl, plag, oxides & $\begin{array}{l}\text { Regime } 3 \text { recrystallized fsp. Bio and hbl riddled with } \\
\text { inclusions of tiny fsp grains and gar may have } \\
\text { recrystallized fsp inclusions. }\end{array}$ \\
\hline AT-01-M11 & $\begin{array}{l}\text { Bio, white mica, Q, } \\
\text { sericitized sill pods, oxides, } \\
\text { gar }\end{array}$ & $\begin{array}{l}\text { See Figure 5a. Main schistose foliation is S2, crenulated } \\
\text { by F3 and beginning development of an axial planar } \\
\text { cleavage (S3). Crenulated sill pods with possible syn-S3 } \\
\text { growth based on fibrolite aligned along F3 axial planes } \\
\text { (In hand sample some pods aligned in S3). Sill pods } \\
\text { enclose tiny fsp grains, matrix fsps have bulging grain } \\
\text { boundaries or polygonal texture. Abundant oxides in } \\
\text { sill. White micas oblique to slide (S3) have inclusion } \\
\text { trails } \sim 45 \text { degrees to S2 -- call these S1. }\end{array}$ \\
\hline AT-01-M12 & Q, bio, hbl, plag & $\begin{array}{l}\text { Folded Q vein } \mathrm{w} / \text { much larger grains than matrix. } \\
\text { Alternating hbl/bio and Q layers = S0/1/2 composite? }\end{array}$ \\
\hline K01-MB-1 & Plag, Q, chloritized bio & \multirow{4}{*}{$\begin{array}{l}\text { sequence 1-4 determined by field relations; sent to } \\
\text { Kevin Chamberlain for U-Pb zircon \& sphene } \\
\text { geochronology } 8 / 15\end{array}$} \\
\hline K01-MB-2 & & \\
\hline K01-MB-3 & & \\
\hline K01-MB-4 & & \\
\hline K01-MB-5 & $\begin{array}{l}\text { large ( }>2 \mathrm{~cm} \text { diameter) } \\
\text { garnets, plag, hbl, bio }\end{array}$ & \\
\hline K01-MB-7 & Q, plag, sill & sill strongly aligned in foliation (S2) \\
\hline K01-MB-8 & gar, sill, fsp & flowy, relationships unclear \\
\hline K01-MB-9 & sill, bio, $Q$, white mica & $\begin{array}{l}\text { F3 crenulation, F2 fold, possible andalusite remnants in } \\
\text { sill pod that contains inclusion trails of (?) at high } \\
\text { angles to S2 }\end{array}$ \\
\hline K01-MB-10 & $\begin{array}{l}\text { pyroxene, amphibole, plag, } \\
\text { bio }\end{array}$ & not oriented \\
\hline K01-MB-11 & Q, plag, micas & F3 fold with no axial planar cleavage \\
\hline
\end{tabular}


Table 1, continued.

Lester Mountain area

\begin{tabular}{|c|c|c|}
\hline AT-01-L2 & $\begin{array}{l}\text { Q, white mica, bio, oxides, } \\
\text { sill }\end{array}$ & $\begin{array}{l}\text { See Figure } 5 \text { d. S0 clearly visible in hand sample, at high } \\
\text { angle to dominant schistose foliation (S2). S2 is } \\
\text { asymmetrically crenulated into "s" folds by F3 (stage } 1 \\
\text { or } 2 \text { crenulation cleavage development), which appear } \\
\text { to fold sill pods (pre-to-syn-S3 sill pod growth). S2 bios } \\
\text { oblique to slide preserve S1 flattened Qtz at high angles } \\
\text { to S2 outside. (Note: S0, S2, S3 clear in hand sample } \\
\text { and thin section; S1 only seen in thin section). In the } \\
\text { field, S3 transecting fabric is counterclockwise to S2. }\end{array}$ \\
\hline AT-01-L3 & $\begin{array}{l}\text { Q, white mica, bio, plag, } \\
\text { andalusite? }\end{array}$ & $\begin{array}{l}\text { See Figure 5e. White mica pseudomorph after } \\
\text { andalusite? 3A: Spaced S2 cleavage at high angles to } \\
\text { S0/1 and crenulated by F3. 3B: S2 is approximately } \\
\text { parallel to S0/1 and crenulated by F3. }\end{array}$ \\
\hline AT-01-L4 & Q, white mica, bio, sill, gar & $\begin{array}{l}\text { See Figure } 5 f \text {. See } \mathrm{S} 0, \mathrm{~S} 2, \mathrm{~S} 3 \text { clearly in hand sample, } \\
\text { with sill pods aligned in } \mathrm{S} 2 \text {. In thin section: } \mathrm{S} 0 \text { is } \\
\text { folded and overprinted by a strong axial planar cleavage } \\
\text { (S2). Gar on limb of F2 contains an S1 inclusion trail at } \\
\text { a high angle to S0 and S2. F3 in hand sample is weak } \\
\text { crenulation of S2 schistose foliation. }\end{array}$ \\
\hline AT-01-L6 & $\begin{array}{l}\text { Q, micas, gar, sill, oxide in } \\
\text { reaction relationship? }\end{array}$ & $\begin{array}{l}\text { Gar anhedral and v. fractured -- inclusions have no clear } \\
\text { orientation (also in bio). Hand sample shows bedding } \\
\text { (S0/S1 composite b/c F1 isoclinal fold visible in field) } \\
\text { and clockwise transecting cleavage (regional S3) and } \\
\text { schistose foliation (regional S2) perpendicular to slide. } \\
\text { Call intersection lineation L2-3. }\end{array}$ \\
\hline AT-01-L10 & $\begin{array}{l}\text { Q, bio, white mica, } \\
\text { resorbed gar }\end{array}$ & $\begin{array}{l}\text { See Figure 5c. Prominent } \mathrm{S} 1 \text { inclusion trails in gar }(\mathrm{Q} \\
\text { ribbons) and bio. Matrix } \mathrm{Q} \text { has polygonal texture and is } \\
\text { fine-grained. S2 is the spaced foliation }(\mathrm{Q}+\mathrm{M} \text { domains). } \\
\text { Gar in Q domains, is flattened parallel to } \mathrm{S} 1 \text { but also } \\
\text { rims overgrow S2 so gar growth syn-to-post-S1 and also } \\
\text { post S2. Bios containing S1 inclusions are aligned in } \\
\text { S3, oblique to slide. }\end{array}$ \\
\hline AT-01-L15 & $\begin{array}{l}\text { Q, bio, white mica, sill, gar } \\
\text { fragments, oxides }\end{array}$ & $\begin{array}{l}\text { sill pods aligned in S2 and folded in dextral sense ("s" } \\
\text { parasitic F3 folds). Gar mainly pre-S3. Main schistose } \\
\text { foliation is S2. }\end{array}$ \\
\hline
\end{tabular}




\section{Table 1, continued.}

\begin{tabular}{|c|c|c|}
\hline AT-01-L16 & $\begin{array}{l}\text { Q, fsp, white mica, bio, sill, } \\
\text { andalusite? }\end{array}$ & $\begin{array}{l}\text { See } \mathrm{S} 0 / 1 \text { (Q veins); } \mathrm{S} 2 \text { is schistose fabric weakly } \\
\text { crenulated by } \mathrm{S} 3 \text { (transecting cleavage } \\
\text { counterclockwise to } \mathrm{S} 0 / 1 \text { ) }\end{array}$ \\
\hline AT-01-L17 & $\mathrm{Q}$, white mica, bio, oxides & $\begin{array}{l}\text { See Figure 5g. 17A: S0/S1 comp layering seen in mica } \\
\text { colors under cross polars (consistent with hand sample). } \\
\text { S2 schistose foliation is approximately perpendicular, } \\
\text { defined by fine-grained alternating layers of musc and } \\
\text { flattened Q (Q \& M domains). Weakly crenulated in } \\
\text { this view (thin section is cut parallel to L3-2 } \\
\text { intersection lineation and perpendicular to S2 - so see } \\
\text { only oblique view of F3 crenulation here). 17B: Strong } \\
\text { "S2" foliation (Q+M spaced cleavage) crenulated by F3. }\end{array}$ \\
\hline AT-01-L19 & Q, carbonate, bio & $\begin{array}{l}\text { Larger Q grains rim carbonate layer; } Q \text { in matrix is fine } \\
\text { grained with regime 2-3 recrystallization textures. }\end{array}$ \\
\hline AT-01-L20A & $\begin{array}{l}\text { Q, bio, white mica, gar-st } \\
\text { layer, sill pod }\end{array}$ & $\begin{array}{l}\text { Gar subhedral, overgrow main fol "S2", have v. fine- } \\
\text { grained inclusion trails parallel to S2. St riddled with } \\
\text { inclusions, oriented at high angle to S2 and deflects S2 } \\
\text { micas, suggesting pre-S2 st growth. }\end{array}$ \\
\hline AT-01-L20B & $\begin{array}{l}\text { Q, bio, musc, gar-st layer, } \\
\text { sill pod }\end{array}$ & $\begin{array}{l}\text { Refolded(?) isoclinal "F2" fold of S0 visible on slide } \\
\text { with naked eye. Resorbed gar and sill in fold hinge. }\end{array}$ \\
\hline K01-LM-20 & $\begin{array}{l}\text { Q, fsp, chloritized bio, hbl, } \\
\text { gar }\end{array}$ & $\begin{array}{l}\text { See Figure } 5 \mathrm{~h} \text {. Gar, hbl riddled w/S1 inclusions at a } \\
\text { high angle to S2-bios outside. Hbl generally aligned } \\
\text { with S1. Some gar are in apparent reaction texture with } \\
\mathrm{S} 3 \text { bios oblique to slide. Oxides in gar aligned w/S1 } \\
\text { inclusions so it is an S0/1 composite foliation. Gar } \\
\text { growth post-S1 and partial deflection of S2 bios around } \\
\text { gar but some gar rims over S2 bios suggest gar grew syn } \\
\text { to-post S2. }\end{array}$ \\
\hline K01-LM-21 & $\begin{array}{l}\text { Q, chloritized bio (haloes), } \\
\text { st, fsp, white mica }\end{array}$ & $\begin{array}{l}\text { S1 inclusions (folded?) in st and S3 bio oblique to slide. } \\
\text { St pre-to-syn-S2. }\end{array}$ \\
\hline K01-LM-22A & $\begin{array}{l}\text { Q, fsp, white mica, bio } \\
\text { (haloes) st, sill }\end{array}$ & $\begin{array}{l}\text { Big st with inclusion trails of flattened Q and fsp } \\
\text { (recrystallized) } \sim 60 \text { degrees to outside foliation (S2), } \\
\text { defined by weak Q+M domains with micas deflected } \\
\text { around st. S3 bio oblique to slide has S1 inclusions } \\
\text { parallel to those in st. }\end{array}$ \\
\hline
\end{tabular}




\begin{tabular}{|c|c|c|}
\hline K01-LM-22B & $\begin{array}{l}\text { Q, fsp, white mica, bio } \\
\text { (haloes) st, sill }\end{array}$ & $\begin{array}{l}\text { Sill pod post-S2. St parallel to S2 (Q\&M domains) } \\
\text { outside, micas are deflected around st. Twinned st has } \\
\text { inclusion trials consistently at high angle to outside S2. }\end{array}$ \\
\hline K01-LM-23 & $\begin{array}{l}\text { Q, fsp, white mica, bio, st, } \\
\text { sill }\end{array}$ & $\begin{array}{l}\text { See Figure } 5 \text { b. Q\&M domains (S2) are transected by } \\
\text { oriented micas at } 45 \text { degrees clockwise (S3). St is } \\
\text { aligned with } \mathrm{S} 1 \text { inclusion trails within, both are aligned } \\
\text { at } \sim 60 \text { to } \mathrm{Q}+\mathrm{M} \text { domains in opposite sense } \\
\text { (counterclockwise) and are also transected by } \mathrm{S} 3 \text { micas. } \\
\text { Some st crystals are rotated to parallel with } \mathrm{S} 2 \text { but } \mathrm{S} 1 \\
\text { trails are still at } 60 \text { degrees to } \mathrm{S} 2 \text {, implying early-syn-S2 } \\
\text { st growth. Bios are also aligned in } \mathrm{S} 3 \text {, which is oblique } \\
\text { to the slide at a shallow angle -- } \mathrm{S} 1 \text { inclusion trails in } \\
\text { these bios is parallel to those in st. }\end{array}$ \\
\hline K01-LM-24 & $\begin{array}{l}\text { Q, fsp, white mica, flat bio } \\
\text { and chl, resorbed st. }\end{array}$ & $\begin{array}{l}\text { See weak alignment of white micas (S2?). St and S3- } \\
\text { aligned bio oblique to slide have unclear inclusion } \\
\text { trails. }\end{array}$ \\
\hline K01-LM-25 & $\begin{array}{l}\text { Q, fsp, white mica, bio, chl, } \\
\text { resorbed gar and st, sill }\end{array}$ & $\begin{array}{l}\text { Prominent straight } \mathrm{S} 1 \text { inclusion trails in gar, st, \& S3- } \\
\text { aligned bio, at high angle to outside foliation defined by } \\
\text { white mica (S2). }\end{array}$ \\
\hline K01-LM-26 & $\begin{array}{l}\text { Q, bio, white mica, gar (in } \\
\text { bio-rich layers) }\end{array}$ & $\begin{array}{l}\text { Compositional layering is inferred to be S0/S1 } \\
\text { composite. See flattened Q in gar \& "flattening" of gar } \\
\text { parallel to compositional layering outside (alternating Q- } \\
\text { and gar-bio-rich layers). Q-polygonal texture. Some bio } \\
\text { oblique to slide is probably the "S3" transecting } \\
\text { cleavage seen in hand sample and throughout the Lester } \\
\text { Mtn quartzite in the field. }\end{array}$ \\
\hline K01-LM-27 & & $\begin{array}{l}\text { sent to Kevin Chamberlain for detrital zircon } \\
\text { geochronolgy } 8 / 15\end{array}$ \\
\hline K01-LM-28 & $\mathrm{Q}$, bio, white mica, gar, st & $\begin{array}{l}\text { Fabrics similar to K01-LM-23 but relations not as clear. } \\
\text { Gar, st, and S3-aligned bio contain inclusion trails at } \\
\text { high angles to "S2" (Q\&M domains) outside, micas are } \\
\text { deflected around gar. }\end{array}$ \\
\hline K01-LM-29 & $\begin{array}{l}\text { Q, fsp (carlsbad twins), bio, } \\
\text { chl }\end{array}$ & $\begin{array}{l}\text { See Appendix A, Figure 1a; sent to Kevin Chamberlain } \\
\text { for geochronology } 8 / 15 \text {; compare to Xca on Farwell } \\
\text { Mtn. }\end{array}$ \\
\hline K01-LM-30 & $\begin{array}{l}\text { Q, white mica, chl, oxides, } \\
\text { rare plag \& kspar }\end{array}$ & $\begin{array}{l}\text { See Figure 51. Q S-C fabric is dextral and some micas } \\
\text { define C-C' shear bands. Oxide(?) preserves flattened Q } \\
\text { at a high angle to the dominant foliation (S2). }\end{array}$ \\
\hline K01-LM-31 & $\begin{array}{l}\text { Q, white mica, bio, gar and } \\
\text { st fragments }\end{array}$ & $\begin{array}{l}\text { S2 micas are deflected around gar and st. Both have } \\
\text { straight S1 inclusion trails almost perpendicular to S2. } \\
\text { Gar are flattened parallel to S1. Weak transecting } \\
\text { foliation (S3) oblique to the slide. Q and white mica } \\
\text { pseudomorph after andalusite? Former sillimanite pod } \\
\text { is completely sericitized. }\end{array}$ \\
\hline
\end{tabular}


Table 1, continued.

\begin{tabular}{|l|l|l|}
\hline K01-LM-32 & $\begin{array}{l}\text { Q, plag, white mica, bio, } \\
\text { gar, sill, st frgaments. }\end{array}$ & $\begin{array}{l}\text { Q\&M domains are S2; gar have straight S1 inclusion } \\
\text { trails almost perpendicular to S2. Sillimanite pods are } \\
\text { folded and sericitized. Weak S3 transecting foliation is } \\
\text { oblique to slide. }\end{array}$ \\
\hline K01-LM-33 & Q, white mica, bio, st & $\begin{array}{l}\text { St has straight S1 inclusion trails at high angles to S2 } \\
\text { but also overgrows S2 micas at edges. The S1 inclusion } \\
\text { trails are generally parallel to the length of the st } \\
\text { crystals, which have been variably rotated (during S2?). }\end{array}$ \\
\hline
\end{tabular}

Along Seedhouse Rd., station no. in ()

\begin{tabular}{|l|l|l|}
\hline AT-01-RD-5 & Hbl, bio, Q, plag & Strongly foliated and lineated \\
\hline
\end{tabular}

Soda Creek -- Fish Creek shear zone

AT-01-S2 $\quad$ Q, plag, ksp, Fe-chl, sphene 2 Dynamic recrystallization textures in Q and fsp. Dextral shear sense. (North side down). 
Table 2. Descriptions of thin sections from samples collected by K. Karlstrom during 1998-1999. Refer to Appendix C for sample list (Table 2) and sample location maps (Plates 4,6,7) in Appendix C for rock types and locations. Q---quartz; ksp---potassium $\mathrm{f}$

\begin{tabular}{|c|c|c|}
\hline Sample \# & Assemblage & Comments \\
\hline K98-PK-12 & Q, ksp, plag, Fe-chl, sphene, hbl & $\begin{array}{l}\text { Q - bulging boundaries. Chloritized bio. } \\
\text { Mylonitic to ultramylonitic shear bands, thrust } \\
\text { sense in field }\end{array}$ \\
\hline K98-PK-13 & Q, ksp, plag, Fe-chl, sphene, hbl & $\begin{array}{l}\text { cataclastic? Low-T simple shear. Chloritized } \\
\text { bio? }\end{array}$ \\
\hline K98-PK-14 & $\begin{array}{l}\text { Q, Fe-chl needles, veins w/chl \& } \\
\text { sphene(?) }\end{array}$ & grain-size-reduced Q, mylonitic S-C fabric. \\
\hline K98-PK-15 & $\mathrm{Q}, \mathrm{Fe}-\mathrm{chl}, \mathrm{hbl}$, fsp clasts, sphene(?) & \\
\hline K98-PK-17 & hbl, Q, bio, chl & $\begin{array}{l}\text { Q ribbons, shear bands, hbl clasts }(\sim 10 \mathrm{~m} \text { wide } \\
\text { myl zone, see } 17 \mathrm{a}-\mathrm{c})\end{array}$ \\
\hline K98-PK-17a & Q, Fe-chl, bio & Chl, bio show SC fabrics \\
\hline K98-PK-17b & Q, Fe-chl, bio & same as $17 \mathrm{a}$ - dextral? \\
\hline K98-PK-17c & Q, Fe-chl, bio, hbl & $\begin{array}{l}\text { hbl porphyroclasts. Ranges from Q-rich to quite } \\
\text { micaceous. }\end{array}$ \\
\hline K98-PK-18 & hbl, bio, chl & hbl for $\mathrm{Ar} / \mathrm{Ar}$ cooling age \\
\hline K98-PK-20 & Q, fsp, chl, micas & $\begin{array}{l}\text { From big injection vein: pseudotachylyte, } \\
\text { microbreccia, mylonite. }\end{array}$ \\
\hline K98-PK-21 & $\begin{array}{l}\text { Px phenocrysts, Q, plag, Fe-chl, } \\
\text { sphene }\end{array}$ & v. fine-grained matrix \\
\hline K98-PK-22 & $\mathrm{Q}, \mathrm{ksp}$ (clasts), plag, bio & $\begin{array}{l}\text { Q ribbons, mylonite zone which truncates } 1.4 \\
\text { Ga mafic dike in field }\end{array}$ \\
\hline K98-PK-23 & Q, plag, chl & $\begin{array}{l}\text { dextral, E side up shear along dike margin. } \\
\text { Mainly Q w/veins of chl }\end{array}$ \\
\hline K98-PK-24 & dolomite/calcite, $\mathrm{Q}$, opaques & $\begin{array}{l}\text { marble }(\mathrm{Xm}) \mathrm{w} / \text { pods of rexallized Q. } \\
\text { Amorphous opaques. }\end{array}$ \\
\hline K98-PK-25a & $\begin{array}{l}\text { Q, ultrafine-grained. Carbonate, } \\
\text { v.fine-grained }\end{array}$ & $\begin{array}{l}\text { fits with } 25 \mathrm{~b} . . \text { lineation changes through folded } \\
\text { sequence of marble units in field. }\end{array}$ \\
\hline K98-PK-25b & calcite, twinned dolomite & $\begin{array}{l}\text { in field noted lineation difference from } 24 \text {. Fits } \\
\text { with } 25 \text { a chert. }\end{array}$ \\
\hline K98-PK-26 & calcite, dolomite, $\mathrm{Q}$ & $\begin{array}{l}\text { interlayered calc-silicate - grain size reduction in } \\
\text { both in some places }\end{array}$ \\
\hline K98-PK-27a & $\begin{array}{l}\text { Q, white mica, bio, resorbed gar, } \\
\text { fibrolite }\end{array}$ & $\begin{array}{l}\text { bedding overturned here; gar porphyroblasts } \\
\text { contain S1; S2 represented by alternating Q \& } \\
\text { mica domains; S3 is transecting fabric of aligned } \\
\text { micas. }\end{array}$ \\
\hline
\end{tabular}




\begin{tabular}{|c|c|c|}
\hline \multicolumn{2}{|c|}{ Table 2 , continued. } & \multirow[b]{2}{*}{$\begin{array}{l}\text { fibrolite in radiating bundles, no preferred } \\
\text { orientation; qtz triple junctions, very minor } \\
\text { undulatory extinction. }\end{array}$} \\
\hline K98-PK-27b & Q, fibrolite, plag? & \\
\hline K98-PK-28 & fibrolite, Q, gar, st?, rutile, bio & $\begin{array}{l}\text { sill pods aligned in foliation. New bio randomly } \\
\text { oriented. Q w/sill seems annealed, rutile needles } \\
\text { present in association with sill pods. }\end{array}$ \\
\hline K98-PK-30 & Q, white mica, bio, chl & $\begin{array}{l}\text { clean fine-grained quartzite, mostly } \\
\text { recrystallized }\end{array}$ \\
\hline K98-PK-31 & Q, bio, white mica, gar, st? & \\
\hline K98-PK-32 & $\mathrm{Q}$, bio, gar, white mica + chl + st? & st breaking down, seems randomly oriented. \\
\hline K98-PK-33 & $\mathrm{Q}$, bio (with haloes), white mica & \\
\hline K98-PK-34 & $\mathrm{Q}, \mathrm{fsp}, \mathrm{Chl}$, bio, resorbed gar & \\
\hline KPK-99-50A & Q, plag, Ksp, hbl & \multirow{3}{*}{$\begin{array}{l}\text { From melt-filled shear bands along F2 fold } \\
\text { limbs in Buffalo Pass granite (Xb) (contains S1, } \\
\text { folded in places) }\end{array}$} \\
\hline KPK-99-50B & Q, plag, Ksp, hbl, ep? & \\
\hline KPK-99-50C & Q, plag, Ksp, hbl, ep? & \\
\hline KPK-99-51 & Q, hbl, plag, Ksp, white mica & $\begin{array}{l}\text { From melt-filled shear bands (S2) in } \mathrm{Xb} \\
\text { containing S1 }\end{array}$ \\
\hline KPK-99-52* & Ksp, Q, plag, hbl, bio, ep? & weak foliation. \\
\hline KPK-99-53A & chl after bio, $\mathrm{Q}$, plag & Mylonite/microbreccia. Some $\mathrm{Q}$ annealed. \\
\hline KPK-99-53B & hbl, bio, Q, plag & mylonitic shear band, some protomylonite. \\
\hline KPK-99-54 & $\mathrm{Q}$, bio, Fe-chl, white mica & $\begin{array}{l}\text { near Buffalo Pass Rd. (see field sketches). Q } \\
\text { ribbons, possible fibrolite in clasts. Mylonite is } \\
\text { 092, 62S. Shear sense is N side down for } \\
\text { mylonitic and ultramylonitic fabrics. }\end{array}$ \\
\hline KPK-99-55 & hbl, Q, Carbonate & $\begin{array}{l}\text { mylonite in marble unit }(\mathrm{Xm}) \text {. Brittle faults - } \\
\text { normal sense? }\end{array}$ \\
\hline KPK-99-56 & hbl, calcite, dol, Q & \\
\hline KPK-99-57 & Q, ksp, plag, carbonate & \\
\hline KPK-99-60 & $\begin{array}{l}\mathrm{Q}, \text { bio, fibrolite, rutile, white mica, } \\
\mathrm{ksp} \text {, resorbed gar }\end{array}$ & $\begin{array}{l}\text { Q with undulose extinction. Sill boudinaged. } \\
\text { Alternating zones of gar+bio OR sill. } \\
\text { Querbioten white micas. }\end{array}$ \\
\hline KPK-99-62 & musc, bio (haloes), sill, Mg-chl, st? & $\begin{array}{l}\text { occasional bio cleavage (S3?) perpendicular to } \\
\text { foliation (S2?) fibrolite intergrown } w / \text { musc }\end{array}$ \\
\hline KPK-99-63 & $\begin{array}{c}\text { olv, Px, orthoamphibole } \\
\text { (anthophyllite?) }\end{array}$ & very fine matrix with porphyroblasts \\
\hline KPK-99-64 & orthoamphibole? & \\
\hline KPK-99-65 & hbl, Q, plag, ksp? & $\begin{array}{l}\text { Very mafic, foliated. Sent for Ar/Ar cooling age } \\
\text { and to Sheila Seaman for petrology/chemistry. }\end{array}$ \\
\hline
\end{tabular}


Table 3. Correlation between structural and metamorphic fabrics in the Farwell Mountain - Lester Mountain suture zone based on geochronologic data [mainly from the Soda Creek - Fish Creek shear zone (SCFC); see Appendix A, Tables 1, 2].

\begin{tabular}{|c|c|c|c|}
\hline $\begin{array}{c}\text { FOLIATION } \\
\text { GENERATION }\end{array}$ & $\begin{array}{c}\text { METAMORPHIC } \\
\text { EVENT }\end{array}$ & $\begin{array}{c}\text { U-PB AGES } \\
\text { (PUblished OR } \\
\text { PRELIMINARY) }\end{array}$ & $\begin{array}{l}\text { CORRELATIVE } \\
\text { FABRICS IN } \\
\text { SCFC }\end{array}$ \\
\hline $\begin{array}{l}\mathrm{S}_{0} \text { (bedding in meta- } \\
\text { sedimentary, volcanic, } \\
\text { volcaniclastic rocks) }\end{array}$ & --- & $\begin{array}{l}1760 \mathrm{Ma} \text { (zircon in } \\
\text { metarhyolite from } \\
\text { Willow Creek } \\
\text { Canyon) }\end{array}$ & $\mathrm{S}_{0}$ in gneisses? \\
\hline $\begin{array}{l}\mathrm{S}_{1} \text { (first tectonic } \\
\text { layering preserved as } \\
\text { inclusion trails in } \\
\text { porphyroblasts) }\end{array}$ & $\begin{array}{l}\mathrm{M}_{1} \text { (staurolite, garnet } \\
\text { growth in Lester Mtn } \\
\text { area, possible time of } \\
\text { kyanite growth) }\end{array}$ & $? ? \geq 1.746 \mathrm{Ga}$ & ?? \\
\hline $\begin{array}{l}\mathrm{S}_{2} \text { (shallowly south- } \\
\text { dipping fabric that is } \\
\text { axial planar to north- } \\
\text { verging, isoclinal, } \\
\text { recumbent folds in the } \\
\text { Lester Mountain area) }\end{array}$ & $\begin{array}{l}\mathrm{M}_{2} \text { (sillimanite pods } \\
\text { aligned in } \mathrm{S}_{2}, 2^{\text {nd }} \\
\text { garnet generation in } \\
\text { Lester Mountain area; } \\
\text { possible timing of } \\
\text { kyanite growth in } \\
\text { SCFC) }\end{array}$ & $\begin{array}{l}\sim 1.746-1.73 \mathrm{Ga} \text { (age } \\
\text { of Buffalo pass } \\
\text { granite, and late-syn- } \\
\text { S1 aplite dike in } \\
\text { shear zone, Rabbit } \\
\text { Ears Pass quartz } \\
\text { diorite) }\end{array}$ & $\mathrm{S}_{1} / \mathrm{M}_{1}$ \\
\hline $\begin{array}{l}\mathrm{S}_{3} \text { (folding and } \\
\text { transposition into } \\
\text { northeast-trending, } \\
\text { subvertical foliation = } \\
\text { regional } \mathrm{S}_{3} \text { ) }\end{array}$ & $\begin{array}{l}\mathrm{M}_{3 \mathrm{a}} \text { (sillimanite pod } \\
\text { growth in Lester } \\
\text { Mountain and Mica } \\
\text { Basin areas, some } \\
\text { garnet rim growth in } \\
\text { Lester Mountain area; } \\
1^{\text {st }} \text { garnet generation } \\
\text { in SCFC) }\end{array}$ & $\begin{array}{l}1.68 \mathrm{Ga} \text { (dark } \\
\text { sphene) } \\
1.68 \mathrm{Ga} \text { (syn- } \mathrm{S}_{2} \text { hbl- } \\
\text { pegmatite dike) } \\
1682 \pm 19 \text { (Th-U-Pb } \\
\text { monazite) }\end{array}$ & $\mathrm{S}_{2} / \mathrm{M}_{2 \mathrm{a}}$ \\
\hline $\begin{array}{l}\text { Continued residence } \\
\text { in middle crust, } \\
\text { heating and/or fluid } \\
\text { flux. Possible } \\
\text { tightening/steepening } \\
\text { of } \mathrm{S}_{2} \text { fabric }\end{array}$ & $\begin{array}{l}\mathrm{M}_{3 \mathrm{~b}} \text { (possible garnet } \\
\text { rim growth in Lester } \\
\text { Mountain area; } 2^{\text {nd }} \\
\text { garnet generation in } \\
\text { SCFC) }\end{array}$ & $\begin{array}{l}1.60 \mathrm{Ga} \text { (pale } \\
\text { sphene) } \\
1610 \pm 22 \text { (Th-U-Pb } \\
\text { monazite) }\end{array}$ & $\mathrm{S}_{2} / \mathrm{M}_{2 \mathrm{~b}}$ \\
\hline $\begin{array}{l}\mathrm{S}_{4} \text { (mylonitic shear, } \\
\text { semi-brittle faults with } \\
\text { pseudotachylyte shear } \\
\text { bands) }\end{array}$ & $\begin{array}{l}\mathrm{M}_{4} \text { (retrograde, } \\
\text { chloritization, fluid } \\
\text { flux; garnet rim } \\
\text { growth in SCFC) }\end{array}$ & $\begin{array}{l}\sim 1.42 \mathrm{Ga} \text { (based on } \\
\text { age of Mount Ethel } \\
\text { pluton) }\end{array}$ & $\mathrm{S}_{3} / \mathrm{M}_{3}$ \\
\hline
\end{tabular}




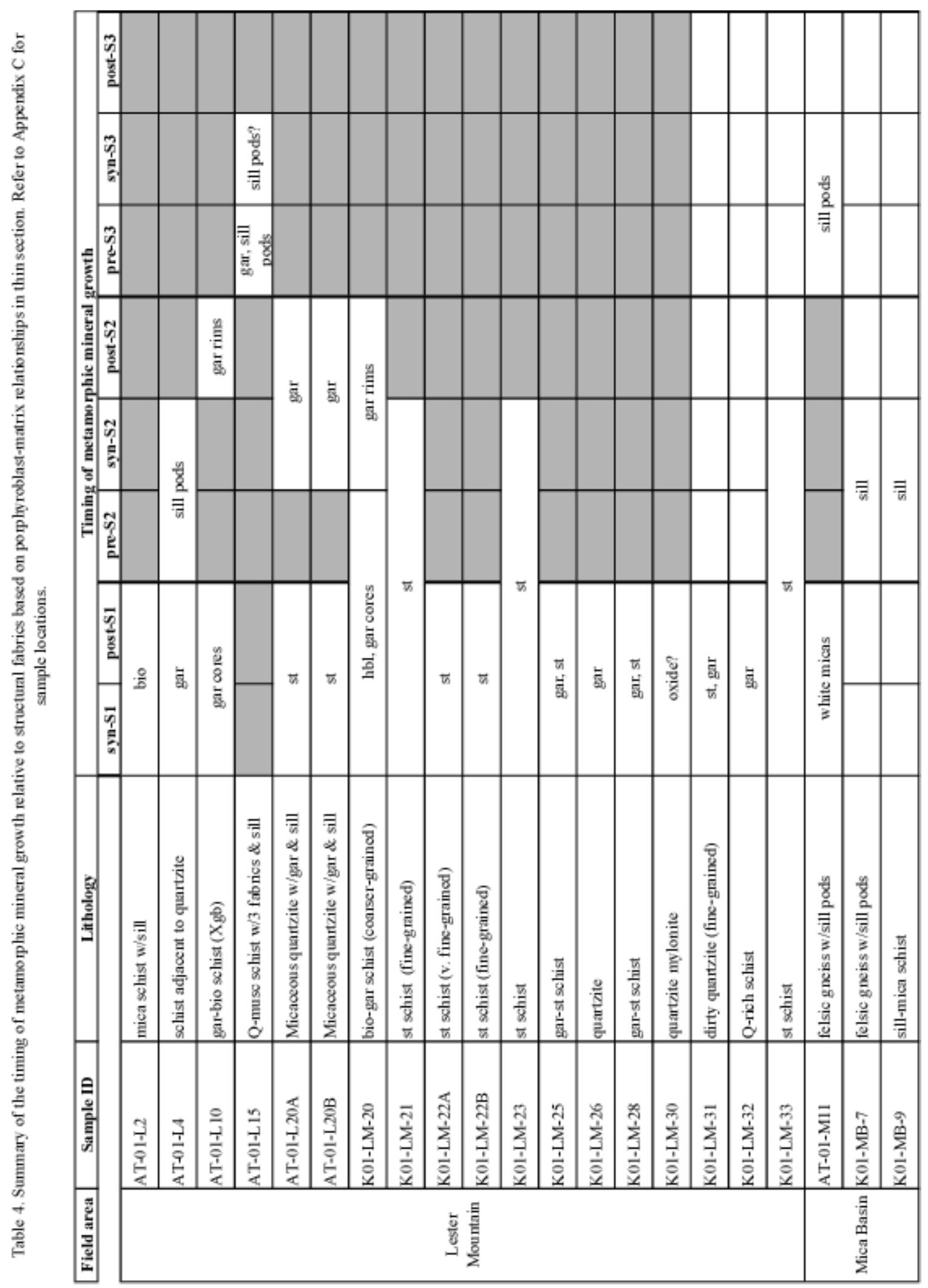


Table 5a. Structural data for the Farwell Mountain area.

S0-S1 foliation

\begin{tabular}{ccc}
\hline Azimuth & Dip & Dip Direction \\
\hline 336 & 70 & E \\
84 & 88 & N \\
52 & 85 & S \\
59 & 80 & S \\
67 & 60 & N \\
64 & 75 & N \\
317 & 64 & E \\
340 & 74 & W \\
85 & 89 & S \\
84 & 57 & N \\
90 & 78 & $N$ \\
119 & 72 & $N$ \\
91 & 67 & $N$ \\
174 & 76 & W \\
35 & 80 & E \\
55 & 80 & N \\
315 & 56 & E \\
335 & 70 & E \\
337 & 83 & E
\end{tabular}

mylonitic shear bands

\begin{tabular}{ccc}
\hline Azimuth & Dip & Dip Direction \\
\hline 100 & 60 & $\mathrm{~N}$ \\
42 & 81 & $\mathrm{~S}$ \\
42 & 70 & $\mathrm{~N}$ \\
282 & 60 & $\mathrm{~N}$ \\
38 & 81 & $\mathrm{E}$ \\
47 & 87 & $\mathrm{E}$ \\
42 & 70 & $\mathrm{~W}$ \\
50 & 76 & $\mathrm{~S}$ \\
128 & 67 & $\mathrm{~N}$ \\
70 & 78 & $\mathrm{~N}$ \\
291 & 61 & $\mathrm{~N}$
\end{tabular}

S2 foliation/F2 axial planes

\begin{tabular}{ccc}
\hline Azimuth & Dip & Dip Direction \\
\hline 272 & 69 & $\mathrm{~N}$ \\
100 & 86 & $\mathrm{~S}$ \\
35 & 79 & $\mathrm{E}$ \\
16 & 83 & $\mathrm{E}$ \\
271 & 69 & $\mathrm{~N}$ \\
& & \\
\multicolumn{5}{c}{ S3 foliation/F3 axial planes } \\
\hline Azimuth & Dip & Dip Direction \\
\hline 60 & 85 & $\mathrm{~S}$ \\
320 & 89 & $\mathrm{E}$ \\
282 & 75 & $\mathrm{~N}$ \\
285 & 75 & $\mathrm{~S}$ \\
125 & 90 & $\mathrm{~N}$ \\
74 & 88 & $\mathrm{~N}$ \\
265 & 90 & $\mathrm{~N}$ \\
264 & 77 & $\mathrm{~N}$ \\
58 & 85 & $\mathrm{~N}$ \\
118 & 50 & $\mathrm{~S}$
\end{tabular}

\begin{tabular}{ccc}
\multicolumn{2}{c}{ lineations } \\
\cline { 1 - 2 } Trend & Plunge & \\
\cline { 1 - 2 } 66 & 64 & \\
323 & 62 & \\
66 & 59 \\
60 & 62 & \\
300 & 76 & \\
98 & 74 & \\
48 & 65 & \\
\multicolumn{4}{c}{} \\
\multicolumn{4}{c}{ brittle faults } \\
\hline Azimuth & Dip & Dip Direction \\
\hline 300 & 85 & $\mathrm{~N}$ \\
282 & 86 & $\mathrm{~S}$ \\
310 & 83 & $\mathrm{~S}$ \\
268 & 81 & $\mathrm{~N}$ \\
288 & 86 & $\mathrm{~N}$
\end{tabular}


Table 5b. Structural data for the Mica Basin area.

S0-S1 foliation

\begin{tabular}{ccc}
\hline Azimuth & Dip & Dip Direction \\
\hline 70 & 66 & $\mathrm{~S}$ \\
74 & 82 & $\mathrm{~S}$ \\
9 & 69 & $\mathrm{~W}$ \\
0 & 58 & $\mathrm{~W}$ \\
45 & 84 & $\mathrm{~S}$ \\
6 & 61 & $\mathrm{~W}$ \\
168 & 80 & $\mathrm{~W}$ \\
32 & 88 & $\mathrm{~W}$ \\
35 & 88 & $\mathrm{~W}$ \\
13 & 88 & $\mathrm{~W}$ \\
43 & 80 & $\mathrm{~W}$ \\
39 & 76 & $\mathrm{~W}$ \\
32 & 85 & $\mathrm{~W}$ \\
142 & 65 & $\mathrm{E}$ \\
42 & 53 & $\mathrm{~W}$ \\
187 & 90 & $\mathrm{~W}$ \\
152 & 60 & $\mathrm{~W}$ \\
80 & 62 & $\mathrm{~S}$ \\
348 & 68 & $\mathrm{~W}$ \\
73 & 77 & $\mathrm{~S}$ \\
56 & 75 & $\mathrm{~S}$ \\
168 & 73 & $\mathrm{~W}$ \\
128 & 76 & $\mathrm{~W}$ \\
84 & 81 & $\mathrm{~S}$ \\
153 & 52 & $\mathrm{~W}$ \\
117 & 49 & $\mathrm{~S}$ \\
30 & 57 & $\mathrm{~W}$ \\
132 & 90 & $\mathrm{~W}$ \\
82 & 56 & $\mathrm{~S}$ \\
159 & 33 & $\mathrm{~W}$ \\
120 & 15 & $\mathrm{~N}$ \\
32 & 88 & $\mathrm{~W}$ \\
& &
\end{tabular}

S0-S1 foliation

\begin{tabular}{ccc}
\hline Azimuth & Dip & Dip Direction \\
\hline 48 & 88 & W \\
54 & 86 & W \\
140 & 53 & S \\
83 & 72 & S \\
79 & 88 & S \\
76 & 83 & S \\
78 & 78 & S \\
33 & 85 & W \\
35 & 76 & W \\
38 & 80 & W \\
38 & 86 & W \\
26 & 85 & W \\
31 & 82 & W \\
105 & 83 & S \\
31 & 68 & E \\
20 & 73 & E \\
170 & 68 & W \\
170 & 75 & E \\
188 & 68 & W \\
163 & 79 & W \\
137 & 61 & W \\
165 & 71 & W \\
160 & 70 & W \\
192 & 62 & W \\
11 & 69 & W \\
176 & 80 & W \\
66 & 63 & W \\
115 & 90 & W \\
43 & 59 & W \\
34 & 59 & W \\
14 & 70 & W \\
10 & 61 & W \\
2 & 52 & W
\end{tabular}


Table 5b, continued. Structural data for the Mica Basin area.

\begin{tabular}{|c|c|c|c|c|c|}
\hline \multicolumn{3}{|c|}{ S2 foliation } & \multicolumn{3}{|c|}{ S2 foliation } \\
\hline Azimuth & Dip & $\begin{array}{c}\text { Dip } \\
\text { Direction }\end{array}$ & Azimuth & Dip & $\begin{array}{c}\text { Dip } \\
\text { Direction }\end{array}$ \\
\hline 53 & 79 & $\mathrm{~N}$ & 45 & 67 & W \\
\hline 62 & 70 & S & 7 & 83 & W \\
\hline 79 & 90 & $\mathrm{~N}$ & 3 & 65 & W \\
\hline 84 & 72 & $\mathrm{~N}$ & 44 & 70 & W \\
\hline 70 & 88 & S & 46 & 66 & W \\
\hline 73 & 90 & $\mathrm{~N}$ & 31 & 90 & $\mathrm{~N}$ \\
\hline 68 & 85 & $\mathrm{~N}$ & 34 & 90 & $\mathrm{~N}$ \\
\hline 80 & 70 & $\mathrm{~N}$ & 55 & 90 & $\mathrm{~N}$ \\
\hline 68 & 87 & S & 142 & 65 & E \\
\hline 62 & 53 & S & 135 & 70 & $E$ \\
\hline 45 & 67 & $\mathrm{~N}$ & 85 & 70 & $\mathrm{~N}$ \\
\hline 56 & 70 & $\mathrm{~N}$ & 170 & 64 & W \\
\hline 51 & 84 & S & 25 & 66 & W \\
\hline 72 & 77 & $\mathrm{~N}$ & 187 & 55 & W \\
\hline 46 & 90 & $\mathrm{~N}$ & 5 & 66 & W \\
\hline 105 & 90 & $\mathrm{~N}$ & 16 & 46 & W \\
\hline 52 & 79 & $\mathrm{~N}$ & 13 & 68 & W \\
\hline 119 & 78 & $\mathrm{~N}$ & 20 & 67 & W \\
\hline 51 & 90 & $\mathrm{~N}$ & 33 & 81 & W \\
\hline 55 & 70 & $\mathrm{~N}$ & 23 & 85 & W \\
\hline 358 & 90 & $\mathrm{~N}$ & 80 & 90 & $\mathrm{~N}$ \\
\hline 63 & 74 & S & 165 & 76 & W \\
\hline 73 & 87 & S & 175 & 80 & W \\
\hline 77 & 88 & S & 155 & 65 & W \\
\hline 112 & 75 & S & 184 & 73 & W \\
\hline 110 & 87 & $\mathrm{~N}$ & 27 & 58 & W \\
\hline 44 & 90 & $\mathrm{~N}$ & 38 & 75 & W \\
\hline 158 & 60 & W & 120 & 88 & $S$ \\
\hline 66 & 90 & $\mathrm{~N}$ & 155 & 50 & W \\
\hline 52 & 84 & $E$ & 175 & 52 & W \\
\hline 14 & 75 & W & 180 & 63 & W \\
\hline & & & 45 & 84 & S \\
\hline
\end{tabular}


Table 5b, continued. Structural data for the Mica Basin area.

\begin{tabular}{|c|c|c|c|c|}
\hline \multicolumn{3}{|c|}{ S3 foliation/F3 axial planes } & \multicolumn{2}{|c|}{ lineations } \\
\hline Azimuth & Dip & Dip Direction & Trend & Plunge \\
\hline 133 & 80 & $\mathrm{~S}$ & 208 & 62 \\
\hline 22 & 90 & $\mathrm{~N}$ & 212 & 62 \\
\hline 37 & 72 & W & 199 & 71 \\
\hline 53 & 65 & W & 217 & 78 \\
\hline 68 & 77 & $\mathrm{~N}$ & 280 & 70 \\
\hline 107 & 75 & W & 185 & 80 \\
\hline 145 & 82 & W & 283 & 65 \\
\hline 83 & 56 & E & 338 & 79 \\
\hline 95 & 90 & $\mathrm{~N}$ & 207 & 50 \\
\hline 130 & 80 & W & 205 & 51 \\
\hline 40 & 88 & W & 335 & 79 \\
\hline 39 & 83 & W & 320 & 80 \\
\hline 20 & 80 & E & 286 & 65 \\
\hline 120 & 60 & S & 273 & 83 \\
\hline 60 & 78 & $\mathrm{~N}$ & 242 & 77 \\
\hline 84 & 90 & $\mathrm{~N}$ & 200 & 60 \\
\hline 75 & 68 & $\mathrm{~N}$ & 243 & 64 \\
\hline 100 & 87 & $\mathrm{~s}$ & 225 & 72 \\
\hline 100 & 79 & $\mathrm{~s}$ & 310 & 80 \\
\hline 75 & 90 & $\mathrm{~N}$ & 281 & 80 \\
\hline 65 & 85 & $\mathrm{~N}$ & 63 & 53 \\
\hline 20 & 90 & $\mathrm{~N}$ & & \\
\hline 15 & 82 & $E$ & & \\
\hline 65 & 70 & $S$ & & \\
\hline 86 & 90 & $\mathrm{~N}$ & & \\
\hline 84 & 72 & $\mathrm{~N}$ & & \\
\hline 80 & 65 & $\mathrm{~N}$ & & \\
\hline
\end{tabular}


Table 5c. Structural data for the Lester Mountain area.

\begin{tabular}{|c|c|c|c|c|c|}
\hline \multicolumn{3}{|c|}{ S0-S1 foliation } & \multicolumn{3}{|c|}{ S0-S1 foliation } \\
\hline Azimuth & Dip & Dip Direction & Azimuth & Dip & $\begin{array}{c}\text { Dip } \\
\text { Direction }\end{array}$ \\
\hline 48 & 85 & $\mathrm{~S}$ & 64 & 58 & $\mathrm{~S}$ \\
\hline 51 & 65 & $\mathrm{~S}$ & 85 & 70 & $S$ \\
\hline 51 & 60 & $S$ & 78 & 67 & $S$ \\
\hline 52 & 90 & $S$ & 56 & 45 & $\mathrm{~S}$ \\
\hline 54 & 66 & $S$ & 94 & 51 & $S$ \\
\hline 57 & 62 & $S$ & 90 & 60 & $S$ \\
\hline 58 & 90 & $S$ & 93 & 44 & $S$ \\
\hline 58 & 61 & $S$ & 109 & 34 & $S$ \\
\hline 58 & 56 & $S$ & 110 & 85 & $\mathrm{~N}$ \\
\hline 59 & 80 & $S$ & 77 & 27 & $\mathrm{~S}$ \\
\hline 59 & 80 & $S$ & 84 & 34 & $S$ \\
\hline 60 & 70 & $S$ & 75 & 26 & $S$ \\
\hline 62 & 90 & $S$ & 150 & 80 & W \\
\hline 64 & 78 & $S$ & 170 & 32 & W \\
\hline 84 & 85 & $S$ & 160 & 20 & W \\
\hline 208 & 61 & W & 40 & 53 & W \\
\hline 217 & 54 & W & 14 & 55 & W \\
\hline 218 & 48 & $\mathrm{~N}$ & 95 & 65 & $S$ \\
\hline 220 & 86 & $\mathrm{~N}$ & 95 & 74 & $S$ \\
\hline 223 & 68 & W & 57 & 54 & $S$ \\
\hline 224 & 70 & $\mathrm{~N}$ & 74 & 72 & $S$ \\
\hline 225 & 63 & W & 66 & 74 & $\mathrm{~N}$ \\
\hline 226 & 36 & W & 140 & 6 & $\mathrm{~N}$ \\
\hline 238 & 85 & $\mathrm{~N}$ & 85 & 69 & $\mathrm{~N}$ \\
\hline 239 & 80 & $\mathrm{~N}$ & 78 & 80 & $S$ \\
\hline 240 & 83 & $\mathrm{~N}$ & 55 & 79 & $S$ \\
\hline 242 & 42 & $\mathrm{~N}$ & 70 & 78 & $S$ \\
\hline 247 & 50 & $\mathrm{~N}$ & 152 & 73 & $\mathrm{~N}$ \\
\hline 259 & 82 & $\mathrm{~N}$ & 117 & 73 & $\mathrm{~N}$ \\
\hline 261 & 74 & $\mathrm{~N}$ & 73 & 75 & $S$ \\
\hline 60 & 70 & $S$ & 85 & 28 & $S$ \\
\hline 58 & 42 & $S$ & 61 & 51 & $S$ \\
\hline 77 & 72 & $\mathrm{~N}$ & 83 & 62 & $S$ \\
\hline 68 & 62 & $S$ & 154 & 52 & $E$ \\
\hline 70 & 84 & $S$ & 64 & 60 & $E$ \\
\hline 72 & 89 & $\mathrm{~N}$ & 45 & 84 & $\mathrm{~N}$ \\
\hline 92 & 90 & & 40 & 78 & $\mathrm{~N}$ \\
\hline 56 & 70 & $\mathrm{~N}$ & 52 & 72 & $\mathrm{~N}$ \\
\hline 40 & 82 & $S$ & 22 & 75 & $\mathrm{~N}$ \\
\hline 74 & 26 & $\mathrm{~N}$ & 40 & 80 & $\mathrm{~N}$ \\
\hline 1 & 13 & W & 55 & 85 & $\mathrm{~N}$ \\
\hline 60 & 62 & $S$ & 80 & 60 & $S$ \\
\hline 77 & 64 & $\mathrm{~N}$ & 38 & 75 & $\mathrm{~N}$ \\
\hline 69 & 74 & $\mathrm{~N}$ & 60 & 75 & $S$ \\
\hline 72 & 78 & $S$ & 64 & 82 & $\mathrm{~N}$ \\
\hline 130 & 52 & $\mathrm{~N}$ & 76 & 49 & $S$ \\
\hline 76 & 78 & $\mathrm{~N}$ & 44 & 83 & $\mathrm{~S}$ \\
\hline 108 & 60 & $\mathrm{~N}$ & 45 & 76 & $S$ \\
\hline 87 & 75 & $S$ & 141 & 74 & $\mathrm{~N}$ \\
\hline 171 & 38 & $E$ & 56 & 54 & $\mathrm{~N}$ \\
\hline 75 & 55 & $S$ & 130 & 4 & $\mathrm{~N}$ \\
\hline 91 & 71 & $S$ & 180 & 13 & W \\
\hline 84 & 75 & $S$ & 90 & 75 & $\mathrm{~N}$ \\
\hline 70 & 35 & $S$ & 70 & 86 & $S$ \\
\hline 45 & 74 & W & 69 & 74 & $\mathrm{~N}$ \\
\hline 145 & 68 & W & 80 & 64 & $\mathrm{~N}$ \\
\hline 55 & 78 & W & 87 & 19 & $\mathrm{~N}$ \\
\hline 36 & 75 & $E$ & 60 & 75 & $S$ \\
\hline 57 & 88 & $\mathrm{~N}$ & 44 & 26 & $S$ \\
\hline 47 & 88 & $E$ & 170 & 38 & $E$ \\
\hline 82 & 73 & $\mathrm{~N}$ & 150 & 24 & $\mathrm{~N}$ \\
\hline 55 & 78 & $\mathrm{~N}$ & 96 & 55 & $S$ \\
\hline 44 & 74 & $\mathrm{~N}$ & 96 & 61 & $S$ \\
\hline 62 & 88 & $\mathrm{~N}$ & 44 & 22 & $\mathrm{~N}$ \\
\hline 40 & 80 & $S$ & 78 & 55 & $S$ \\
\hline 64 & 89 & $S$ & 91 & 79 & $S$ \\
\hline 49 & 82 & $\mathrm{~N}$ & 118 & 60 & W \\
\hline 39 & 82 & $S$ & 72 & 89 & $N$ \\
\hline 55 & 64 & $S$ & 102 & 85 & $S$ \\
\hline
\end{tabular}


Table 5c, continued. Structural data for the Lester Mountain area.

\begin{tabular}{|c|c|c|c|c|c|}
\hline \multicolumn{3}{|c|}{ S2 foliation } & \multicolumn{3}{|c|}{ S2 foliation } \\
\hline Azimuth & Dip & $\begin{array}{c}\text { Dip } \\
\text { Direction }\end{array}$ & Azimuth & Dip & $\begin{array}{c}\text { Dip } \\
\text { Direction }\end{array}$ \\
\hline 29 & 66 & $E$ & 90 & 90 & $\mathrm{~N}$ \\
\hline 30 & 90 & E & 150 & 8 & $E$ \\
\hline 68 & 79 & $S$ & 44 & 25 & $\mathrm{~N}$ \\
\hline 84 & 41 & $S$ & 60 & 14 & $S$ \\
\hline 85 & 60 & $S$ & 60 & 26 & $S$ \\
\hline 90 & 61 & $S$ & 80 & 45 & $S$ \\
\hline 91 & 28 & $S$ & 90 & 50 & $S$ \\
\hline 94 & 29 & $S$ & 60 & 40 & $S$ \\
\hline 94 & 29 & $S$ & 62 & 37 & $S$ \\
\hline 97 & 31 & S & 42 & 73 & $S$ \\
\hline 97 & 13 & 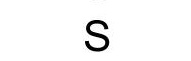 & 55 & 56 & $S$ \\
\hline 255 & 65 & $\mathrm{~N}$ & 23 & 52 & $\mathrm{~s}$ \\
\hline 263 & 67 & $N$ & 134 & 14 & S \\
\hline 264 & 67 & $N$ & 81 & 12 & $S$ \\
\hline 332 & 55 & E & 128 & 23 & $\mathrm{~N}$ \\
\hline 135 & 19 & $\mathrm{~N}$ & 84 & 35 & $S$ \\
\hline 66 & 82 & $\mathrm{~N}$ & 66 & 44 & $S$ \\
\hline 79 & 49 & $S$ & 62 & 56 & $S$ \\
\hline 145 & 6 & $\mathrm{~N}$ & 130 & 16 & $E$ \\
\hline 120 & 14 & $\mathrm{~N}$ & 301 & 14 & $\mathrm{~N}$ \\
\hline 97 & 90 & $\mathrm{~N}$ & 64 & 52 & $\mathrm{~N}$ \\
\hline \multirow{3}{*}{55} & 85 & $\mathrm{~N}$ & 82 & 20 & S \\
\hline & & & 133 & 19 & $E$ \\
\hline & & & 164 & 21 & $E$ \\
\hline
\end{tabular}


Table 5c, continued. Structural data for the Lester Mountain area.

\begin{tabular}{|c|c|c|c|c|c|}
\hline \multicolumn{3}{|c|}{ S3 foliation/F3 axial planes } & \multicolumn{3}{|c|}{ S3 foliation/F3 axial planes } \\
\hline Azimuth & Dip & Dip Direction & Azimuth & Dip & Dip Direction \\
\hline 31 & 86 & $\mathrm{E}$ & 85 & 75 & $\mathrm{~S}$ \\
\hline 39 & 90 & $\mathrm{E}$ & 86 & 88 & S \\
\hline 42 & 74 & $E$ & 88 & 90 & $S$ \\
\hline 50 & 74 & S & 92 & 5 & $\mathrm{~s}$ \\
\hline 50 & 75 & $S$ & 94 & 63 & $S$ \\
\hline 51 & 90 & $S$ & 104 & 54 & $S$ \\
\hline 52 & 90 & $S$ & 111 & 65 & S \\
\hline 52 & 10 & $E$ & 115 & 52 & S \\
\hline 52 & 10 & $E$ & 117 & 12 & S \\
\hline 53 & 66 & $E$ & 125 & 11 & $S$ \\
\hline 54 & 26 & $E$ & 130 & 71 & W \\
\hline 54 & 26 & S & 193 & 37 & W \\
\hline 55 & 81 & $S$ & 210 & 57 & W \\
\hline 56 & 49 & $S$ & 210 & 57 & W \\
\hline 58 & 62 & $S$ & 214 & 71 & W \\
\hline 59 & 90 & S & 218 & 8 & W \\
\hline 60 & 53 & $S$ & 236 & 70 & $\mathrm{~N}$ \\
\hline 61 & 70 & $S$ & 241 & 73 & $\mathrm{~N}$ \\
\hline 61 & 65 & $S$ & 242 & 54 & $\mathrm{~N}$ \\
\hline 62 & 71 & $S$ & 243 & 77 & $\mathrm{~N}$ \\
\hline 62 & 70 & S & 244 & 76 & $\mathrm{~N}$ \\
\hline 62 & 63 & $S$ & 254 & 57 & $\mathrm{~N}$ \\
\hline 63 & 80 & $S$ & 264 & 67 & $\mathrm{~N}$ \\
\hline 63 & 39 & $S$ & 270 & 76 & $\mathrm{~N}$ \\
\hline 63 & 15 & $S$ & 74 & 70 & $S$ \\
\hline 63 & 39 & $S$ & 86 & 74 & $S$ \\
\hline 63 & 15 & $S$ & 88 & 76 & $\mathrm{~N}$ \\
\hline 64 & 72 & $S$ & 80 & 82 & $S$ \\
\hline 64 & 76 & $S$ & 122 & 68 & $\mathrm{~N}$ \\
\hline 65 & 83 & $S$ & 118 & 70 & $\mathrm{~N}$ \\
\hline 65 & 67 & $S$ & 61 & 76 & $S$ \\
\hline 65 & 63 & $S$ & 120 & 16 & $\mathrm{~N}$ \\
\hline 65 & 74 & $S$ & 85 & 85 & $S$ \\
\hline 65 & 80 & $S$ & 109 & 83 & $\mathrm{~N}$ \\
\hline 65 & 35 & $S$ & 76 & 79 & $S$ \\
\hline 66 & 59 & $S$ & 91 & 55 & $S$ \\
\hline 66 & 68 & $S$ & 117 & 68 & $S$ \\
\hline 67 & 71 & $S$ & 61 & 87 & $S$ \\
\hline 68 & 79 & $S$ & 60 & 79 & $S$ \\
\hline 68 & 35 & $S$ & 75 & 76 & $S$ \\
\hline 69 & 76 & $S$ & 80 & 70 & $\mathrm{~N}$ \\
\hline 69 & 74 & $S$ & 57 & 43 & $S$ \\
\hline 69 & 67 & $S$ & 78 & 83 & $S$ \\
\hline 70 & 73 & $S$ & 268 & 64 & $S$ \\
\hline 70 & 70 & $S$ & 60 & 76 & $S$ \\
\hline 70 & 90 & $S$ & 60 & 60 & $S$ \\
\hline 72 & 78 & $S$ & 130 & 66 & $E$ \\
\hline 73 & 69 & $S$ & 125 & 70 & $\mathrm{~N}$ \\
\hline 76 & 59 & $S$ & 123 & 68 & $\mathrm{~N}$ \\
\hline 78 & 81 & $S$ & 52 & 85 & W \\
\hline 79 & 81 & $S$ & 90 & 90 & $\mathrm{~N}$ \\
\hline 80 & 79 & $S$ & 82 & 85 & $S$ \\
\hline 81 & 23 & $S$ & 109 & 90 & $\mathrm{~N}$ \\
\hline 81 & 61 & $S$ & 100 & 87 & $\mathrm{~N}$ \\
\hline 82 & 66 & $S$ & 70 & 79 & $\mathrm{~N}$ \\
\hline 82 & 75 & $S$ & 68 & 64 & $S$ \\
\hline 84 & 67 & $S$ & 50 & 72 & $S$ \\
\hline 85 & 75 & $S$ & 74 & 63 & $\mathrm{~N}$ \\
\hline 85 & 66 & $S$ & 72 & 70 & $S$ \\
\hline 86 & 74 & $S$ & 74 & 49 & $S$ \\
\hline
\end{tabular}


Table 5d. Structural data for the Soda Creek -- Fish Creek shear zone.

\begin{tabular}{|c|c|c|c|c|c|}
\hline \multicolumn{3}{|c|}{ S1 foliation } & \multicolumn{3}{|c|}{ S1 foliation } \\
\hline Azimuth & Dip & Dip Direction & Azimuth & Dip & Dip Direction \\
\hline 25 & 88 & $\mathrm{E}$ & 238 & 72 & $\mathrm{~N}$ \\
\hline 35 & 66 & $S$ & 239 & 51 & $\mathrm{~N}$ \\
\hline 37 & 90 & E & 240 & 50 & $\mathrm{~N}$ \\
\hline 47 & 81 & $\mathrm{~S}$ & 240 & 57 & $\mathrm{~N}$ \\
\hline 48 & 75 & $E$ & 240 & 79 & $\mathrm{~N}$ \\
\hline 48 & 90 & $E$ & 241 & 58 & $\mathrm{~N}$ \\
\hline 58 & 89 & S & 241 & 65 & $\mathrm{~N}$ \\
\hline 61 & 74 & S & 243 & 80 & $\mathrm{~N}$ \\
\hline 65 & 84 & $S$ & 243 & 59 & $\mathrm{~N}$ \\
\hline 68 & 74 & $S$ & 243 & 52 & $\mathrm{~N}$ \\
\hline 70 & 81 & $S$ & 245 & 88 & $\mathrm{~N}$ \\
\hline 74 & 85 & S & 247 & 68 & $\mathrm{~N}$ \\
\hline 76 & 64 & S & 247 & 85 & $\mathrm{~N}$ \\
\hline 76 & 83 & $S$ & 248 & 56 & $\mathrm{~N}$ \\
\hline 78 & 71 & S & 250 & 52 & $\mathrm{~N}$ \\
\hline 80 & 90 & S & 251 & 77 & $\mathrm{~N}$ \\
\hline 123 & 81 & $S$ & 254 & 52 & $\mathrm{~N}$ \\
\hline 126 & 88 & W & 254 & 39 & $\mathrm{~N}$ \\
\hline 152 & 73 & W & 254 & 71 & $\mathrm{~N}$ \\
\hline 158 & 69 & W & 256 & 58 & $\mathrm{~N}$ \\
\hline 158 & 69 & W & 258 & 75 & $\mathrm{~N}$ \\
\hline 187 & 65 & $\mathrm{~N}$ & 260 & 66 & $\mathrm{~N}$ \\
\hline 190 & 85 & W & 260 & 71 & $\mathrm{~N}$ \\
\hline 195 & 71 & W & 261 & 52 & $N$ \\
\hline 201 & 82 & W & 261 & 49 & $\mathrm{~N}$ \\
\hline 203 & 65 & W & 262 & 65 & $\mathrm{~N}$ \\
\hline 203 & 73 & W & 265 & 35 & $\mathrm{~N}$ \\
\hline 214 & 72 & W & 266 & 64 & $\mathrm{~N}$ \\
\hline 215 & 75 & W & 266 & 41 & $\mathrm{~N}$ \\
\hline 224 & 60 & W & 266 & 61 & $\mathrm{~N}$ \\
\hline 224 & 44 & W & 268 & 77 & $\mathrm{~N}$ \\
\hline 225 & 74 & W & 268 & 32 & $\mathrm{~N}$ \\
\hline 225 & 66 & W & 271 & 86 & $\mathrm{~N}$ \\
\hline 225 & 70 & W & 272 & 69 & $\mathrm{~N}$ \\
\hline 227 & 78 & W & 272 & 56 & $\mathrm{~N}$ \\
\hline 228 & 60 & W & 277 & 50 & $\mathrm{~N}$ \\
\hline 231 & 70 & $\mathrm{~N}$ & 281 & 24 & $N$ \\
\hline 235 & 83 & $\mathrm{~N}$ & 282 & 42 & $\mathrm{~N}$ \\
\hline 235 & 61 & W & 283 & 64 & $\mathrm{~N}$ \\
\hline 236 & 78 & W & 284 & 90 & $S$ \\
\hline 236 & 82 & W & 287 & 70 & $\mathrm{~N}$ \\
\hline 236 & 80 & W & 301 & 90 & $\mathrm{~N}$ \\
\hline 354 & 83 & $E$ & 305 & 88 & $N$ \\
\hline 90 & 67 & $\mathrm{~N}$ & 343 & 82 & $E$ \\
\hline 30 & 78 & $S$ & & & \\
\hline
\end{tabular}


Table 5d, continued. Structural data for the Soda Creek -- Fish Creek shear zone.

S2 foliation/F2 axial planes

\begin{tabular}{cc}
\hline Azimuth & Dip \\
\hline 40 & $76 \mathrm{E}$ \\
63 & $90 \mathrm{~S}$ \\
68 & $74 \mathrm{~S}$ \\
85 & $90 \mathrm{~S}$ \\
86 & $70 \mathrm{~S}$ \\
90 & $67 \mathrm{~S}$ \\
96 & $81 \mathrm{~S}$ \\
139 & $62 \mathrm{~W}$ \\
232 & $74 \mathrm{~W}$ \\
244 & $87 \mathrm{~N}$ \\
265 & $79 \mathrm{~N}$ \\
260 & $49 \mathrm{~N}$
\end{tabular}

quartz and pegmatite veins

\begin{tabular}{rr}
\hline Azimuth & Dip \\
\hline 4 & $25 \mathrm{E}$ \\
16 & $57 \mathrm{E}$ \\
20 & $56 \mathrm{E}$ \\
34 & $66 \mathrm{E}$ \\
41 & $55 \mathrm{E}$ \\
50 & $74 \mathrm{~S}$ \\
50 & $75 \mathrm{~S}$ \\
62 & $71 \mathrm{~S}$ \\
135 & $76 \mathrm{~S}$ \\
136 & $69 \mathrm{~S}$ \\
143 & $63 \mathrm{~S}$ \\
145 & $84 \mathrm{~S}$ \\
201 & $84 \mathrm{~W}$ \\
218 & $54 \mathrm{~W}$ \\
225 & $76 \mathrm{~W}$ \\
250 & $60 \mathrm{~N}$ \\
271 & $66 \mathrm{~N}$ \\
271 & $50 \mathrm{~N}$ \\
273 & $54 \mathrm{~N}$
\end{tabular}

mylonitic shear bands

\begin{tabular}{|c|c|c|}
\hline Azimuth & Dip & Dip Direction \\
\hline 20 & 76 & $\mathrm{E}$ \\
\hline 45 & 90 & $E$ \\
\hline 58 & 84 & $S$ \\
\hline 90 & 80 & $S$ \\
\hline 235 & 86 & W \\
\hline 236 & 88 & $\mathrm{~N}$ \\
\hline 53 & 86 & $\mathrm{~N}$ \\
\hline 22 & 55 & W \\
\hline 35 & 53 & $\mathrm{~N}$ \\
\hline 54 & 46 & $\mathrm{~N}$ \\
\hline 76 & 86 & $\mathrm{~N}$ \\
\hline 92 & 62 & $S$ \\
\hline 110 & 76 & $S$ \\
\hline 51 & 66 & $\mathrm{~N}$ \\
\hline 50 & 77 & $\mathrm{~N}$ \\
\hline 70 & 78 & $\mathrm{~N}$ \\
\hline 236 & 88 & $\mathrm{~N}$ \\
\hline 235 & 86 & $\mathrm{~N}$ \\
\hline 50 & 78 & $\mathrm{~N}$ \\
\hline 58 & 72 & $\mathrm{~N}$ \\
\hline \multicolumn{3}{|c|}{ brittle faults } \\
\hline Azimuth & Dip & Dip Direction \\
\hline 16 & & \\
\hline 22 & & \\
\hline 22 & & \\
\hline 45 & & \\
\hline 53 & & \\
\hline 72 & & \\
\hline 180 & & \\
\hline 262 & & \\
\hline 293 & & \\
\hline 298 & & \\
\hline 304 & & \\
\hline 304 & & \\
\hline 305 & & \\
\hline 309 & & \\
\hline 358 & & \\
\hline
\end{tabular}




\section{APPENDIX E. MONAZITE DATING AND OTHER GEOCHRONOLOGIC DATA}

Preliminary in-situ Th-U-Pb monazite dating for this study was conducted with the help of Mike Spilde in the SEM lab and Nelia Dunbar in the electron microprobe lab at New Mexico Tech. This radiometric dating method (e.g. Scherrer et al., 2000; Montel et al., 1996) is especially valuable because it places absolute dates in a microstructural and petrographic context. Because this method is quick and inexpensive relative to more traditional radiometric dating techniques, it is feasible to run a number of analyses on a variety of samples. An additional benefit is that zoning can often be detected by elemental mapping of monazite grains, and different age domains can sometimes be correlated with structural fabrics or metamorphic events. Existing U-Pb zircon, U-Pb metamorphic sphene and Th-U-Pb monazite dates (Appendix A, Table 1) for samples from various locations within the study area serve in assessing the validity of new microprobe monazite dates and in the placement of timing constraints on the Proterozoic kinematic and metamorphic history of the area. Various workers over the past decade have used and refined this method and have shown its effectiveness as a precise dating method in contexts similar to that in this study (e.g. Shaw et al., 2001; Williams and Jercinovic, 2000a,b; 2002; Williams, et al., 2000)

Monazite $\left[(\mathrm{Ce}, \mathrm{La}, \mathrm{Nd}, \mathrm{Th}, \mathrm{Y}) \mathrm{PO}_{4}\right]$ is an accessory mineral found in many igneous and metamorphic rocks. Because it contains $\mathrm{U}$ and $\mathrm{Th}$ but almost no common $\mathrm{Pb}$, measuring the concentrations of these three elements at any point on a monazite grain with the electron microprobe allows us to calculate the age of the grain. This age will be 
accurate as long as the following assumptions are true: (1) all $\mathrm{Pb}$ present is daughter product from the radioactive decay of $\mathrm{U}$ and $\mathrm{Th},(2)$ the grain is a closed system; i.e., no change has occurred in elemental concentrations by any means other than radioactive decay, and (3) the ${ }^{235} \mathrm{U} /{ }^{238} \mathrm{U}$ in the grain is the same as the average ${ }^{235} \mathrm{U} /{ }^{238} \mathrm{U}$ of the crust (Montel et al., 1996; Cocherie et al., 1998).

Sample K98-PK-27a (Figure 1), a garnet-bearing quartz-rich mica schist from the east side of Willow Creek Canyon off the south flank of Lester Mountain (Map Station 14), was selected for in situ microprobe monazite dating after detailed microstructural analysis demonstrated that it clearly preserves three tectonic fabrics and at least one generation of metamorphism. The dominant " $\mathrm{S}_{2}$ " foliation in the Lester Mountain quartzite-schist sequence is defined to be alternating " $\mathrm{Q}+\mathrm{M}$ " domains of quartz and aligned micas. Bedding $\left(\mathrm{S}_{0}\right)$ can be seen at an angle to $\mathrm{S}_{2}$ in hand sample and by contrasting colors of micas under crossed polars. Garnet porphyroblasts in "Q" domains contain straight " $\mathrm{S}_{1}$ " quartz inclusion trails that are, on average, orthogonal to $\mathrm{S}_{2}$ (Figure 1). Some garnets have narrow, inclusion-free rims that overgrow $S_{2}$ micas. Thus, garnet cores are interpreted to represent latest-syn- $\mathrm{S}_{1}$ to early-syn- $\mathrm{S}_{2}$ metamorphism and rims post- $S_{2}$ growth. Fibrous sillimanite is aligned in $S_{2}$ and/or occurs in $S_{2}$ strain shadows around garnets, suggesting that peak metamorphism occurred during $\mathrm{S}_{2}$ (P-T path presented by White (1987)). Where unpinned, quartz in this region appears to have regime 2-3 (Hirth and Tullis, 1992) dynamic recrystallization textures and is partially annealed into a polygonal foam texture $\left(\sim 400^{\circ} \mathrm{C}\right)$. Quartz grain shape preferred orientation (GSPO) is aligned with $\mathrm{S}_{2}$. 


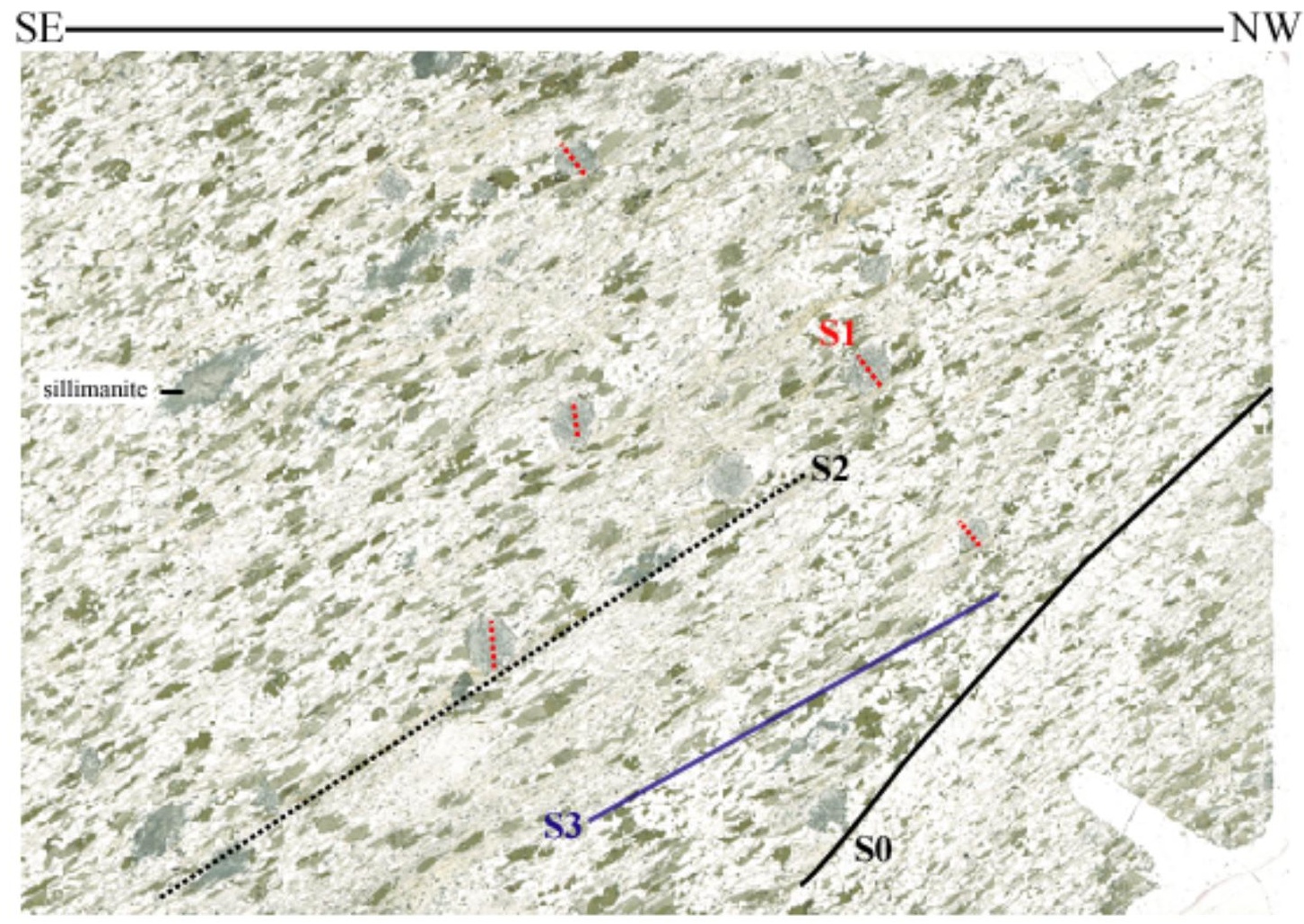

Figure 1. Thin section of Lester Mountain quartz-rich mica schist K98-PK-27a. Above: Entire thin section scan $(26 \times 40 \mathrm{~mm})$ oriented in cross sectional view looking southwest (to azimuth 235 ). Below: two garnets $(\sim 0.6 \mathrm{~mm}$ across each) and a fibrous sillimanite pod in the strain shadow between them. Garnets are in the quartz domains between micaceous layers of the S2 foliation. S1 inclusion trails (red) in garnets are at high angles to the S2 foliation. S3 micas are oblique to the plane of the slide and in this view are subparallel to $\mathrm{S} 2$. Some biotite grains have S1 trails parallel to those in garnet. S2: $055,70 \mathrm{~S} ; \mathrm{S} 3: 115,63 \mathrm{~S}$.

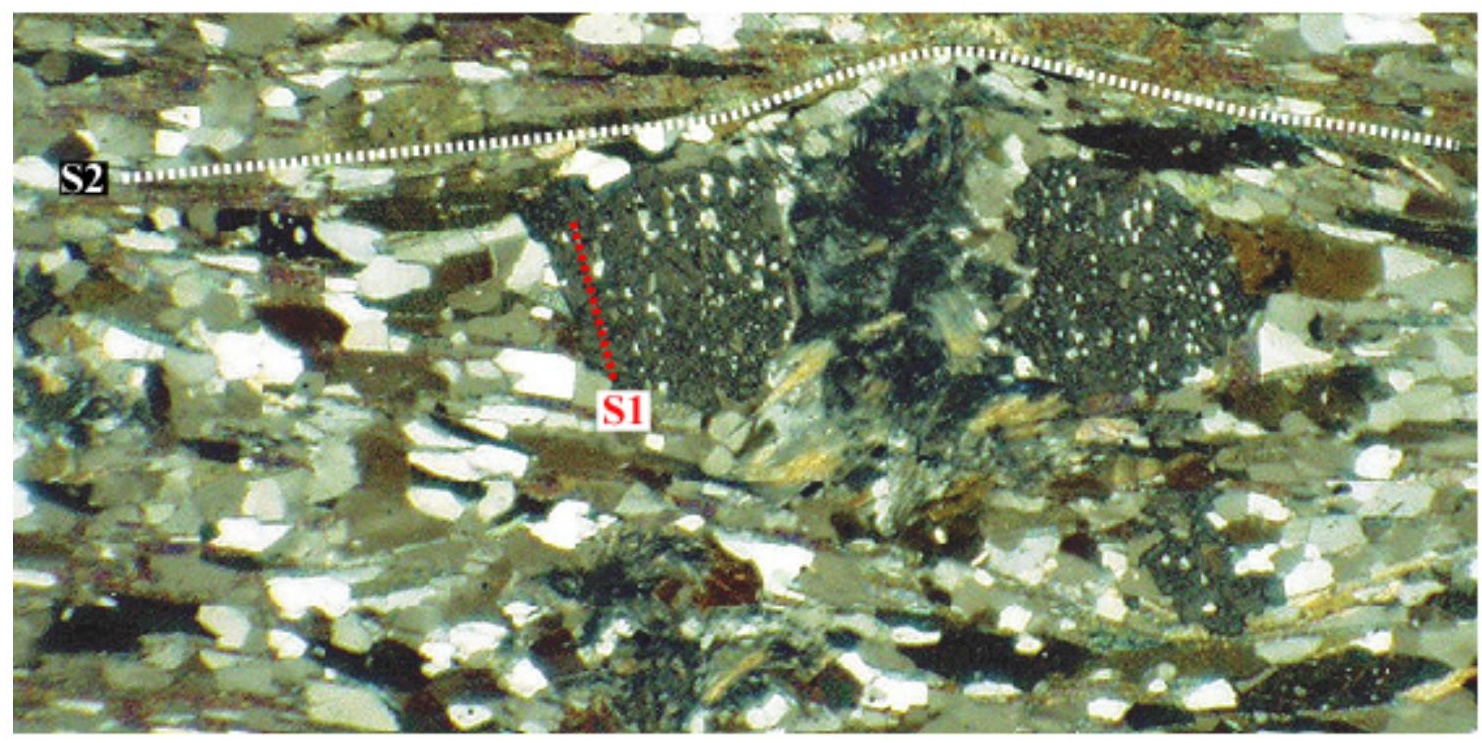


Two monazite grains in the K98-PK-27a thin section were selected for analysis via backscattered electron imaging (Figure 2). Elemental mapping on the electron microprobe identified U-compositional zoning (core and rim) in the larger of the two selected monazite grains (K98-PK-27a-1; Figure 2a), which is aligned in $\mathrm{S}_{2}$. The second grain (K98-PK-27a-2; Figure 2b) lies on the boundary between a garnet porphyroblast and a biotite grain aligned in $\mathrm{S}_{3}$.

Monazite K98-PK-27a-1 is approximately $700 \mu \mathrm{m}^{2}$ and is aligned in the $\mathrm{S}_{2}$ foliation. Ages from spot analyses ranged from 1514-1545 Ma in the rim and 1543-1593 Ma in the core (Table 1; Figure 2a). This broad, overlapping pattern in spot ages and the anhedral, fringy rim of this grain suggest that fluid infiltration may have partially dissolved and re-precipitated monazite, either continuously or in discrete pulses over a period of $\sim 80$ m.y.

Although elemental mapping of K98-PK-27a-2 showed no compositional zoning, three spot analyses yielded preliminary ages of $1578 \mathrm{Ma}$ in the center and 1530 and 1543 Ma in the "wings" of the elongate grain (Table 1, Figure 2b). This grain is aligned in $\mathrm{S}_{2}$ and lies along a boundary between garnet and biotite, with an apparent reaction texture between the monazite and garnet. If the garnet is syn- and post- $\mathrm{S}_{2}$ as discussed above, then this monazite grain must be latest-syn-to-post- $\mathrm{S}_{2}$.

Other monazite ages from the microprobe at New Mexico Tech have turned out to be $\leq 100 \mathrm{~m}$.y. younger than ages obtained for the same grains at the more-established monazite microprobe dating laboratory of Williams and Jercinovic at the University of Massachusetts-Amherst. This is likely due to inaccuracy in the selection of background levels. Table 1 in Appendix A shows that the geochronologic data produced prior to this 


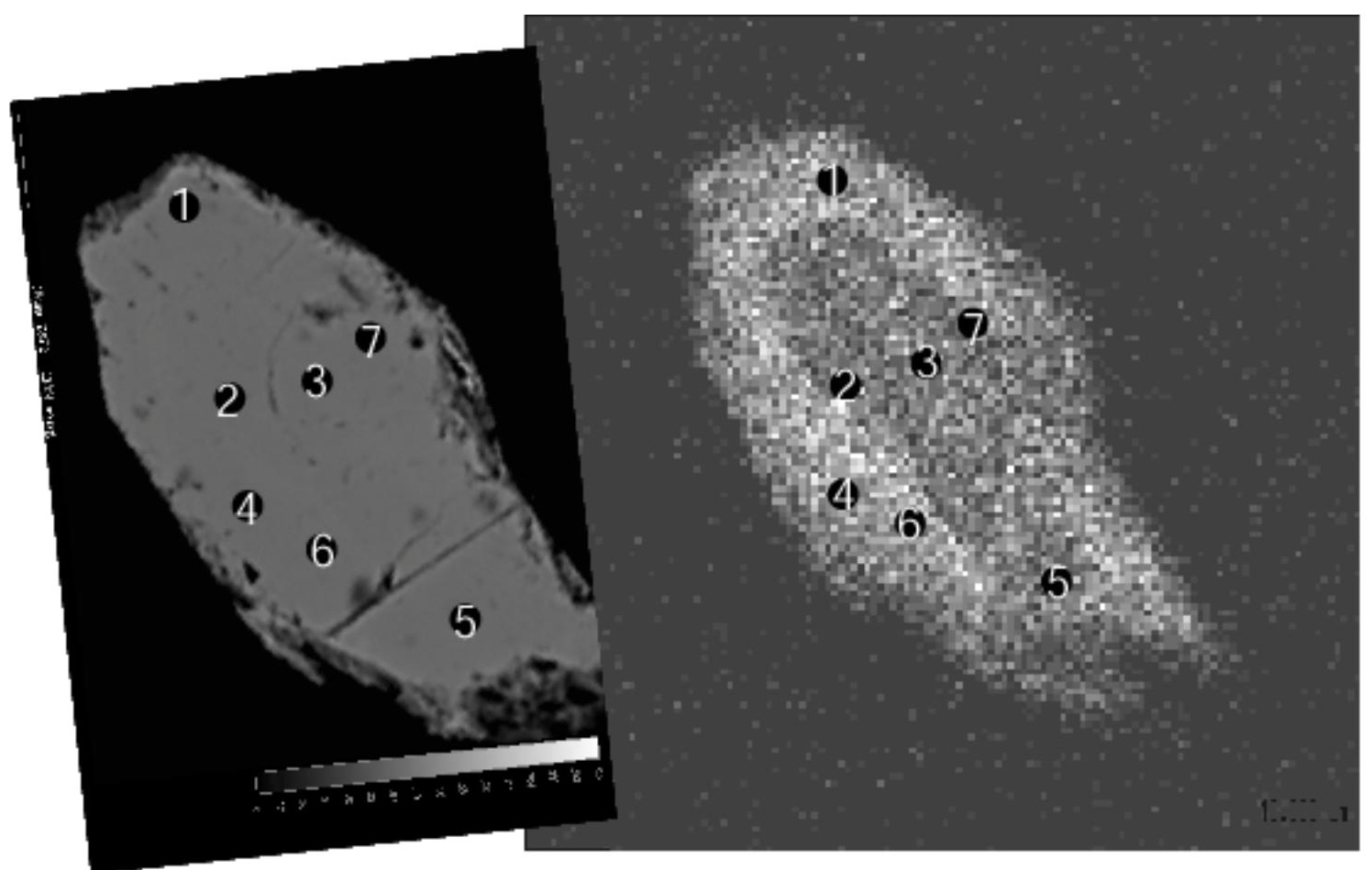

Figure 2a. Monazite K98-PK-27a-1 (flattened and aligned in S2 fabric): Uranium elemental map (right) and backscattered electron image (left) with approximate locations of spot analyses. Preliminary ages (Ma): $1=1530,2=1562,3=1512,4=1545,5=1543,6=1514$,
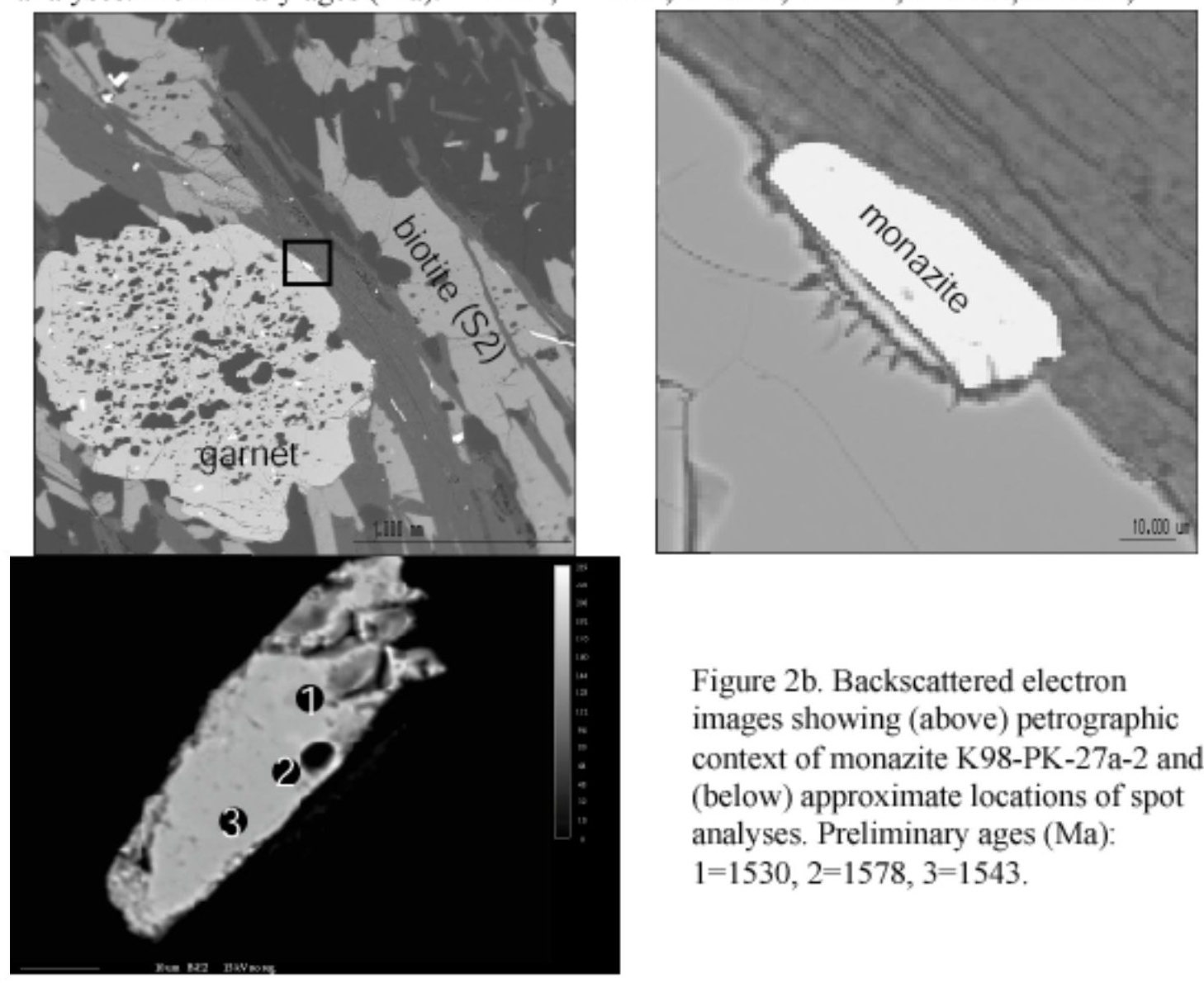

Figure 2b. Backscattered electron images showing (above) petrographic context of monazite K98-PK-27a-2 and (below) approximate locations of spot analyses. Preliminary ages (Ma): $1=1530,2=1578,3=1543$. 


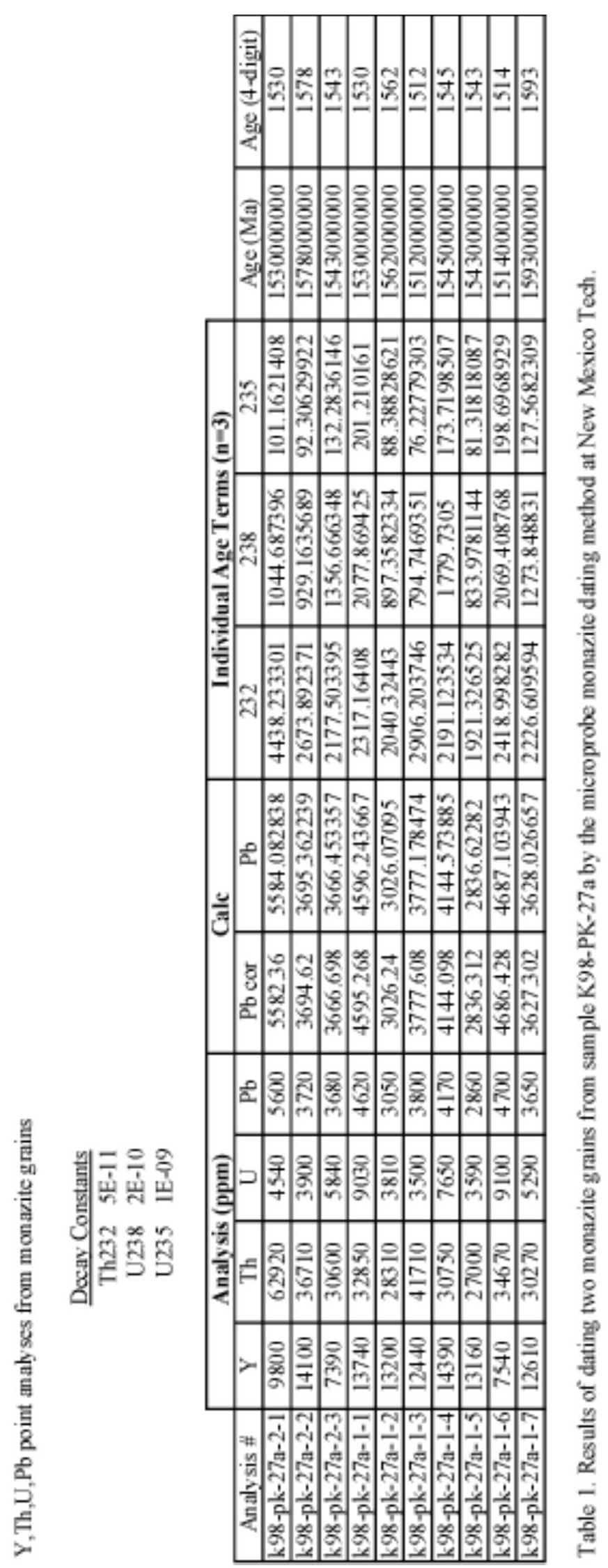


study have yielded a minimum metamorphic age of $1600 \mathrm{Ma}(\mathrm{U}-\mathrm{Pb}$ metamorphic sphene) in the Soda Creek - Fish Creek shear zone. I thus interpret the 1.5-1.6 Ga ages for both monazites as a minimum age of $1.5 \mathrm{Ga}$ for $\mathrm{D}_{2}$ in the Lester Mountain area, consistent with the $\sim 1680$ Ma date for deformation in the Soda Creek - Fish Creek shear zone (Appendix D, Table 3).

Ar/Ar cooling ages (Table 2) for the Park Range are from the lab of Matt Heizler at New Mexico Tech and come from samples collected by Colin Shaw in 1997, Karl Karlstrom in 1998-2000, and me in 2000. "Preferred" ${ }^{40} \mathrm{Ar} /{ }^{39} \mathrm{Ar}$ ages (Colin Shaw, personal communication, 2001) for sample K98-PK-27a biotite and muscovite are

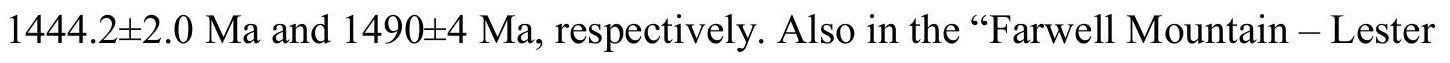
Mountain suture zone", hornblende ages from 3 Farwell Mountain samples ranged from $\sim 1460$ to 1550 Ma. A sample from Willow Creek Canyon, south of Lester Mountain, yielded a hornblende age of $\sim 1650$ Ma. A hornblende age from a sample near Pearl, Colorado is $\sim 1580 \mathrm{Ma}$.

The ${ }^{40} \mathrm{Ar}{ }^{39} \mathrm{Ar}$ results from a transect across the southern margin of the ca. $1.42 \mathrm{Ga}$ Mount Ethel Pluton (Table 2; Figure 3) suggest that biotite was widely reset ca. $1.4 \mathrm{Ga}$ during the intrusion but hornblende was reset to ca. $1.42 \mathrm{Ga}$ only in a sample from a large amphibolite xenolith within the pluton. Hornblende ages from amphibolite samples in the Soda Creek - Fish Creek shear zone are 1.56-1.55 Ga. Further south, in samples from an amphibolite screen and metagabbroic dike surrounded by the 1746 Ma Buffalo Pass pluton, hornblende ages are 1.68-1.65 Ga. All these ages are consistent with a $>1.5 \mathrm{Ga}$ age for the regional metamorphic event which the monazite dates may represent. Further, 
Table 2. Results of 40Ar/39Ar dating on Park Range samples (M. Heizler and C. Shaw). Refer to Figure 3 for sample locations. Hbl---hornblende age; bio---biotite age; musc---muscovite age

\begin{tabular}{|c|c|c|c|}
\hline Sample ID & Station No. & Location Description & Preferred Ar Date in $10^{6}$ years (mineral) \\
\hline K00-FM-1 & $\mathrm{K} 1$ & Farwell Mtn. & $\begin{array}{c}1460.8+/-1.9 \text { (hbl integrated age); } 1296+/-11 \\
\text { (bio) }\end{array}$ \\
\hline K00-FM-2 & $\mathrm{K} 1$ & Farwell Mtn. & $1550+/-4(\mathrm{hbl})$ \\
\hline K00-FM-3 & K3 & Farwell Mtn. & $1529+/-3(\mathrm{hbl})$ \\
\hline $\begin{array}{l}\text { KK99-PK- } \\
\quad 65\end{array}$ & 63 & Pearl, CO & $1579+/-2$ (hbl integrated age) \\
\hline K98-PK-27a & 14 & $\begin{array}{l}\text { Willow Creek Canyon (south } \\
\text { of Lester Mtn.) }\end{array}$ & 1444.2+/-2.0 (bio); 1490+/-4 (musc) \\
\hline LM-00-15 & 13 & $\begin{array}{l}\text { Willow Creek Canyon (south } \\
\text { of Lester Mtn.) }\end{array}$ & $1648+/-3$ (hbl integated age) \\
\hline 97Park2-h & \multirow{9}{*}{$\begin{array}{l}\text { Refer to } \\
\text { Figure } \\
\text { prepared by } \\
\text { C. Shaw }\end{array}$} & $\begin{array}{l}\text { foliated amphibolite in Buffalo } \\
\text { Pass granite }\end{array}$ & $1684+/-6$ (hbl) \\
\hline 97Park2-b,k & & Buffalo Pass granite & $1402.5+/-1.3$ (bio) \\
\hline 97Park6-h & & \multirow{2}{*}{$\begin{array}{l}\text { metagabbro-diorite dike } \\
\text { across from runaway truck } \\
\text { ramp }\end{array}$} & $1647+/-13(\mathrm{hbl})$ \\
\hline 97Park6-b,k & & & $1426+/-2$ (bio) \\
\hline 97Park9-b & & $\begin{array}{l}\text { granodiorite near Steamboat } \\
\text { Springs }\end{array}$ & $1350+/-10$ (bio) \\
\hline 97Park10-h & & $\begin{array}{l}\text { amphibolite in Soda Creek -- } \\
\text { Fish Creek shear zone, }\end{array}$ & $1548+/-6$ (hbl) \\
\hline 97Park11-h & & $\begin{array}{l}\text { hortheast OT Steamboat } \\
\text { Springs }\end{array}$ & $1567+/-7(\mathrm{hbl})$ \\
\hline 97Park11 & & $\begin{array}{l}\text { ferrodiorite dike, same } \\
\text { location as 97Park11-h }\end{array}$ & $1428+/-9$ (bio) \\
\hline 97Park12-c & & $\begin{array}{l}\text { near southern margin of the } \\
\text { Mt. Ethel pluton }\end{array}$ & $1426+/-4(\mathrm{hbl})$ \\
\hline
\end{tabular}



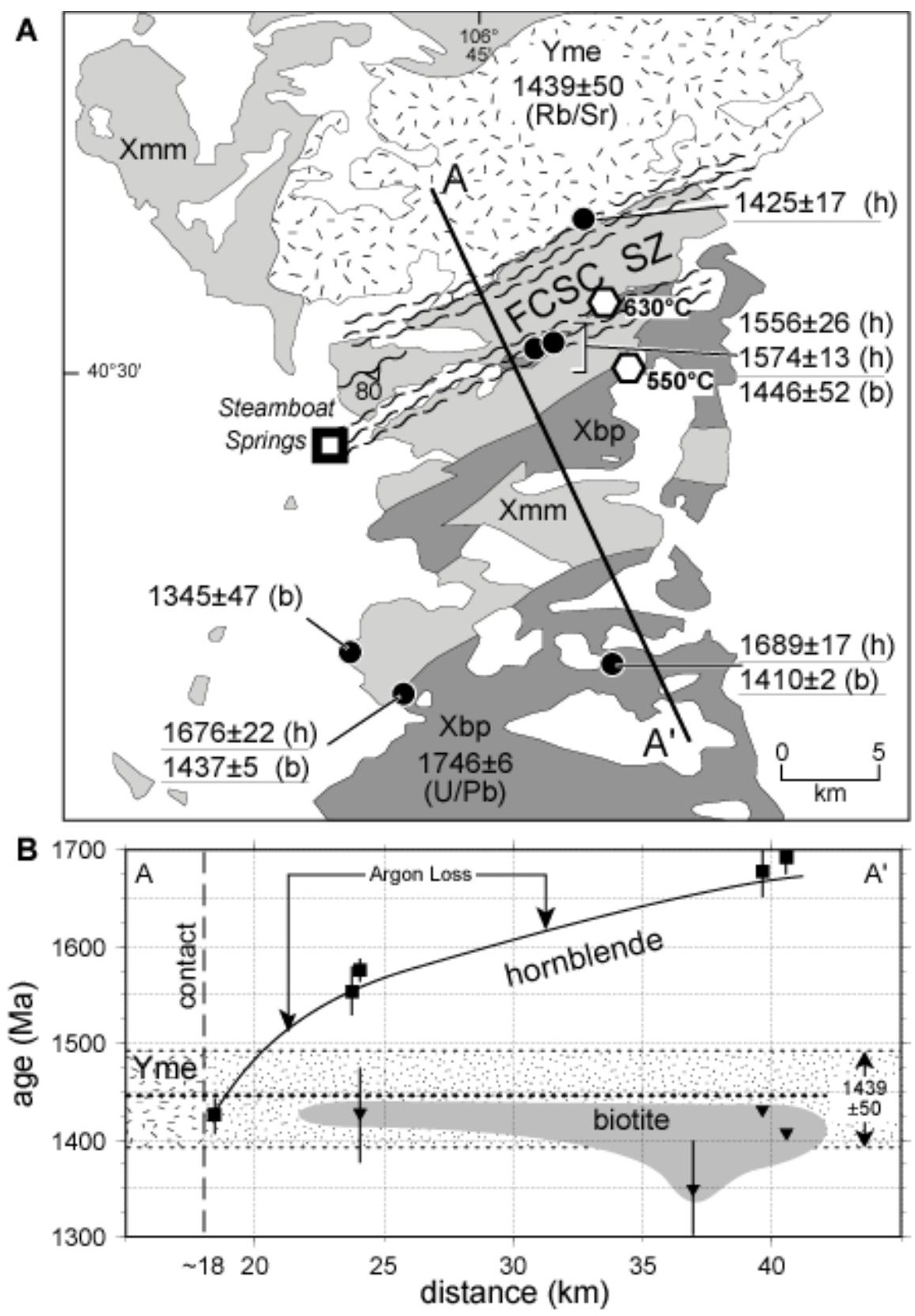

Figure 3 (Colin Shaw, unpublished data): A) Generalized geologic map of the central Park Range, North Central Colorado (after Tweto, 1979, Snyder, 1980) showing ca. 1.7 Ga Buffalo Pass Pluton (Xbp; dark gray), Paleoproterozoic schists and gneisses (Xmm; light gray), 1440 Ma Mt. Ethel Batholith (Yme; pattern; Rb/Sr, Reed, 1993), and Fish Creek-Soda Creek shear zone (FCSZ). B) ${ }^{40} \mathrm{Ar} /{ }^{39} \mathrm{Ar}$ dates projected onto a plane approximately normal to the sheared pluton margin (A-A') to emphasize the gradient in hornblende ages south of the pluton. Biotite ages and hornblende dates at pluton margin are concordant with the age of the Mt. Ethel batholith. Metamorphic temperatures (open hexagons) within the Mt. Ethel aureole were calculated by Barinek et al. (1999) using garnetbiotite exchange thermometer. 
they may suggest that monazite grains could have been partially reset if fluids infiltrated the "Farwell Mountain - Lester Mountain suture zone" and the Soda Creek - Fish Creek shear zone while the rocks were at temperatures high enough to partially reset hornblende during the period 1600-1400 Ma. At ca. 1.4 Ga, the regional temperature away from the Mount Ethel pluton must have been between approximately 350 and $550^{\circ} \mathrm{C}$ (based on the closure temperatures for hornblende and biotite; Colin Shaw, personal communication, 2001).

In summary, a complex history of reheating makes it difficult to accurately constrain the timing of metamorphism for the region. Future work may allow for the use of microprobe monazite dating to refine this history, in combination with $\mathrm{U}-\mathrm{Pb}$ dating of metamorphic sphene, which will be continued by Kevin Chamberlain. Timing constraints are essential to the testing and refining of the kinematic and tectonic hypothesis presented in this paper. 


\section{APPENDIX F. SEISMIC LINE AND COMBINED CROSS SECTION}

Seismic reflection data from the CD-ROM Cheyenne belt seismic line were provided by Morozova et al. (2002). The seismic reflection profile has been adjusted to 1:48,000 scale with no vertical exaggeration so that the geologic cross section can be superimposed at true map scale (Plate 9). Cdp markers on the geologic section correspond to those on Plate 1a and are aligned with the cdp scale on the seismic section. Picks (Morozova et al., 2002) from this seismic section are represented as red lines in Figure 2, the combined CD-ROM cross section presented in the main text. Results are discussed in the text and in Appendix G. 


\section{APPENDIX G. TECTONIC MODEL}

The tectonic model (Figure 3 in the main text) presented in this paper was selected as the most feasible scenario to account for geometries that persist in the crust and upper mantle beneath the Cheyenne belt and "Farwell Mountain - Lester Mountain suture zone." To construct this model, scale drawings were created beginning with the typical island arc of Hamilton (1979), as shown in Figure 1, and ending with the geometries constructed from the combined CD-ROM interpreted cross section (Figures 2, $3 \mathrm{E}$ in the main text). Assuming approximately $20 \%$ post-accretionary north-south shortening gives the "post-accretionary" geometry shown in Figure 3D in the main text. Various tectonic cartoons were constructed to arrive at this "post-accretionary" geometry, assuming that the north-dipping high-velocity body is evidence of a subducted slab of Proterozoic oceanic lithosphere.

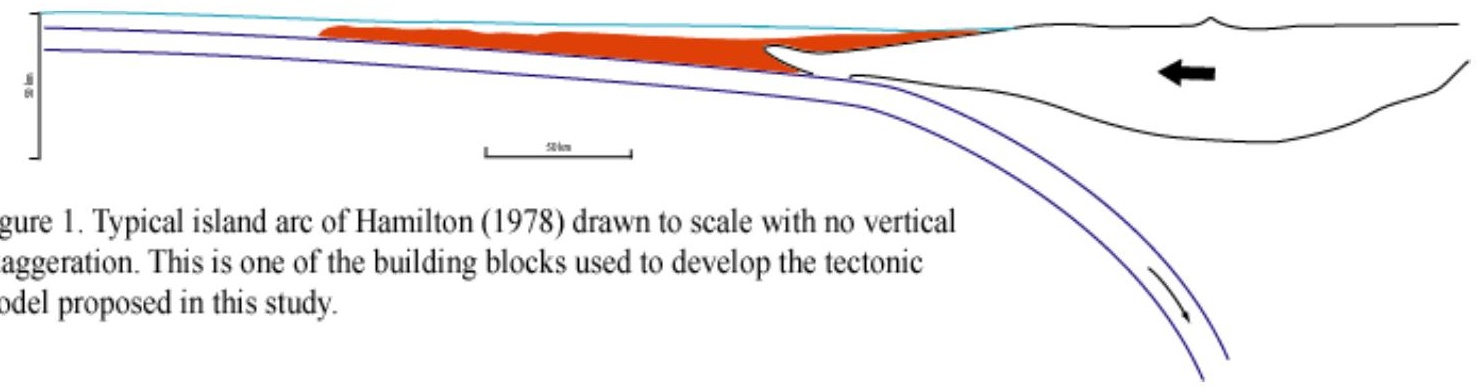

The two main alternatives hinge on the origin of the "slab" - either Green Mountain arc oceanic lithosphere, or a remnant of ca. 2.1 Ga oceanic lithosphere that was produced during rifting of the southern margin of the Wyoming Archean craton. The 
drawings show (Figure 3 in the main text) that the collision of the accretionary wedge of the island arc with the Archean continental margin would have occurred when there was an approximately 200 -km-long segment of $\sim 2.1 \mathrm{Ga}$ oceanic lithosphere remaining between the two bodies. Although the depth resolution of the mantle tomography is not very precise, the high-velocity body is about $200 \mathrm{~km}$ long (deep). Thus, the ca. $2.1 \mathrm{Ga}$ segment of oceanic lithosphere seems a good candidate for becoming the "slab" that we infer to represent very short-lived, northward subduction.

The alternative explanation is that Green Mountain oceanic lithosphere moved northward, presumably by shearing along a detachment at the base of the arc crust, and was underthrust northward against the Archean margin. Scale drawings of this latter scenario illustrate that difficulties arise in terms of area (volume) and other spatial concerns. For example, what happened to the remaining piece of ca. $2.1 \mathrm{Ga}$ oceanic lithosphere that was part of the Archean continental plate? Is there any evidence of shearing either at the base of the island arc crust or evidence for the ca. 2.1 Ga oceanic lithosphere being delaminated?

The scenario chosen for this paper is the simpler one and more consistent with the available data. It is by no means the only possible explanation, however, and it is limited by its two-dimensional nature. Other possible interpretations for the high-velocity body include (1) an Archean slab that remained when the southern Archean block was rifted away ca. $2.1 \mathrm{Ga}$, or (2) delaminated Archean lithosphere from the north. (Because the anomaly reaches the base of the crust, it is highly unlikely that it represents asthenospheric downwelling.) Additional seismic data along-strike and through other 
Proterozoic exposures might be very useful in placing additional constraints on the possibilities for tectonic models for the region.

Cavosie and Selverstone (2002) present evidence for the role of subvertical structures in oceanic crust in shaping the subsequent tectonic evolution of the Colorado Province, specifically in the northern Front Range. Unfortunately, seismic reflection data cannot image steep structures and thus do not provide a test of this hypothesis along the Cheyenne belt line. Kinematic studies thus far suggest that although steep fabrics are quite prevalent in the Park Range study area, they nearly always appear to transect or transpose earlier fabrics that have unknown, but possibly shallowly dipping, original orientations. Further exploration of the along-strike continuity of Park Range structures may help determine how fragmentary is the history of the Colorado Province. The degree of tectonic imbrication and variation in kinematic history even over the field area for this study may suggest that many different crustal origins and assembly mechanisms make up the "orogeny" that we are attempting to understand.

The results of this study in the Park Range do highlight several differences with the model of Cavosie and Selverstone (2002) that is based primarily on their work in the Buckhorn Creek shear zone. Perhaps cross-applying the methods used in each approach to the other field area would help to formulate a model that incorporates the characteristics of both. The Buckhorn Creek shear zone, if comparable to other shear zones in Colorado like the Soda Creek - Fish Creek shear zone, may have a complex history of multiple movements for which the absolute timing has not yet been finely resolved. This type of work would help to demonstrate whether the present orientations of foliations and lineations in the Buckhorn Creek and other shear zones represents the 
original orientation during high-temperature shear or some component of rotation during subsequent events.

Due to the complex movement histories in shear zones and a lack of the necessary geochemical data to evaluate possible ophiolites, the origins of mafic to ultramafic bodies and tectonic mélange in the southwestern U.S. continue to be subjects of debate. One may argue that the broad and scattered distribution of these rock types across Colorado, Arizona, and New Mexico is consistent with the hypothesis that the orogen contains dismembered accretionary complexes bearing ophiolite slivers. However, this hypothesis is not a unique solution to the problem. Alternate hypotheses, including the proposed role of subvertical oceanic fracture zones, should be considered as workers continue to investigate the assembly history of the southwestern U.S. 


\section{REFERENCES}

Aleinikoff, J.N., Reed, J.C., Jr., and Wooden, J.L., 1993, Lead isotopic evidence for the origin of Paleo- and Mesoproterozoic rocks of the Colorado Province, USA:

Precambrian Research, v. 63, p. 97-122.

Ayarza, P., Brown, D., Alvarez-Marron, J., Juhlin, C., 2000, Contrasting tectonic history of the arc-continent suture in the Southern and Middle Urals: implications for the evolution of the orogen: Journal of the Geological Society of London, v. 157, p. 1065-1076.

Barinek, M., 1997, Metamorphism and deformation associated with the $\sim 1.4$ Ga Mount Ethel pluton, northern Park Range, Colorado [M.S. thesis]: Iowa City, University of Iowa, $127 \mathrm{pp}$.

Barinek, M.F., Foster, C.T., Chaplinsky, P.P., 1999, Metamorphism and deformation near the $1.4-G a$ Mount Ethyl pluton, Park Range, Colorado: Rocky Mountain Geology, v.34, p. 21-35.

Beamish, D. and Smythe, D.K., 1986, Geophysical images of the deep crust: the Iapetus suture: Journal of the Geological Society, London, v. 143, p. 489-497.

Bekker, A., 2001, Tectonic implications of a chemostratigraphic study of Early Paleoproterozoic carbonates from the southeastern margin of the Wyoming craton: Geological Society of America Abstracts, Rocky Mountain Section Annual Meeting, April 30 - May 2, 2001.

Bell, T.H. and Rubenach, M.J., 1983, Sequential porphyroblast growth and crenulation cleavage development during progressive deformation: Tectonophysics 92, p.171194.

Bennett, V.C. and DePaolo, D.J., 1987, Proterozoic crustal history of the western United States as determined by neodymium isotopic mapping: Geological Society of America Bulletin, v. 99, p. 674-685.

Blackwelder, E., 1926, Pre-Cambrian geology of the Medicine Bow Mountains: Geological Society of America Bulletin, v. 37, p. 636-641.

Bowring, S.A. and Karlstrom, K.E., 1990, Growth, Stabilization, and reactivation of Proterozoic lithosphere in the southwestern United States: Geology, v.18, p.12031206. 
Cavosie, A.J. and Selverstone, J., 2002, Early Proterozoic oceanic crust in the northern Colorado Front Range: Implications for crustal growth and initiation of basement faults: Tectonics, in press.

Chadwick, R.A. and Holliday, D.W., 1991, Deep crustal structure and Carboniferous basin development within the Iapetus convergence zone, northern England: Journal of the Geological Society, London, v. 148, p. 41-53.

Chamberlain, K.R., 1998, Medicine Bow Orogeny: Timing of deformation and model of crustal structure produced during continent-arc collision, ca. $1.78 \mathrm{Ga}$, southeastern Wyoming: Rocky Mountain Geology, v. 33, p. 259-277.

-----, 1997, Widespread ca. 2.0 Ga rifting in southeastern Wyoming Province: evidence from U-Pb crystallization ages, uplift ages, hydrothermal zircon growth, and reset $\mathrm{Rb}-\mathrm{Sr}$ and U-Pb systematics: Geological Society of America Abstracts with Programs, v. 29, no. 6, p. A-467.

Chaplinsky, P.P., 1987, Deformational aspects and tectonic setting of the Fish CreekSoda Creek mylonite zone [M.S. thesis]: Iowa City, University of Iowa, 127 pp.

Cocherie, A., Legendre, O., Peucat, J.J., Kouamelan, A., 1998, Geochronology of polygenic monazites constrained by in situ electron microprobe Th-U-Total $\mathrm{Pb}$ determination: implications for $\mathrm{Pb}$ behavior in monazite: Geochimica et Cosmochimica Acta, v. 62, p. 2475-2497.

Condie, K.C., 1982, Plate-tectonics model for Proterozoic continental accretion in the southwestern United States: Geology, v.10, p. 37-42.

------, 1992, Proterozoic terranes and continental accretion in southwestern North America, in Condie, K.C., ed., Proterozoic crustal evolution: Elsevier Precambrian series.

Condie, K.C. and Shadel, C., 1984, An early Proterozoic arc succession in southeastern Wyoming: Canadian Journal of Earth Sciences, v. 231, p. 415-427.

Cook, F.A., van der Velden, A.J., Hall, K.W., and Roberts, B.J., 1998, Tectonic delamination and subcrustal imbrication of the Precambrian lithosphere in northwestern Canada mapped by LITHOPROBE: Geology, v. 26, p. 839-842.

Dann, J., 1991, A Proterozoic ophiolite in central Arizona; Implications for models of crustal growth: Geology, v. 19, p. 590-593.

DePaolo, D.J., 1981, Neodymium isotopes in the Colorado Front Range and crust-mantle evolution in the Proterozoic: Nature, v. 271, p. 193-196. 
Dewey, J.F., 1977, Suture zone complexities: a review: Tectonophysics, v. 40, p. 53-67.

Ding, Z., Yang, Y., Yao, Z., and Zhang, G., 2001, A thin-skinned collisional model for the Taiwan orogeny: Tectonophysics, v. 332, p. 321-331.

Divis, A.F., 1976, Geology and geochemistry of the Sierra Madre Range, Wyoming: Colorado School of Mines Quarterly, v.71, no.3, 127 pp.

Duebendorfer, E.M. and Houston, R.S., 1986, Kinematic history of the Cheyenne belt: A Proterozoic suture in southeastern Wyoming: Geology, v. 14, p. 171-174.

------, 1987, Proterozoic accretionary tectonics at the south margin of the Archean Wyoming craton: Geological Society of America Bulletin, v. 98, p.554-568.

------, 1990, Structural analysis of a ductile-brittle Precambrian shear zone in the Sierra Madre, Wyoming: western extension of the Cheyenne belt: Precambrian Research, v. 48, p. 21-39.

Dueker, K., Yuan, H., and Zurek, B., 2001, Thick-structured Proterozoic lithosphere of the Rocky Mountain Region: GSA Today, v. 11, p. 4-9.

Edwards, B.R., 1993, A field, geochemical, and isotopic investigation of the igneous rocks in the Pole Mountain area of the Sherman batholith, southern Laramie Mountains, Wyoming, U.S.A. [M.S. thesis]: Laramie, University of Wyoming, $164 \mathrm{pp}$.

Eiler, J.M., 1989, Metamorphic history of the northern Park Range, Colorado: Constraints on the tectonic setting of the Fish Creek-Soda Creek mylonite zone [Senior Honors' thesis]: Iowa City, University of Iowa, $68 \mathrm{pp}$.

Erdmer, P.E., 1985, An examination of the cataclastic fabrics and structures of parts of Nisutlin, Anvil, and Simpson allochthons, central Yukon: test of the arc-continent collision model: Journal of Structural Geology, v. 7, p. 57-72.

Flurkey, A.J., 1983, Depositional environment and petrology of the Medicine Peak Quartzite (Early Proterozoic), southern Wyoming [PhD. Thesis]: Laramie, University of Wyoming.

Foster, C.T., Reagan, M.K., Kennedy, S.G., Smith, G.A., White, C.A., Eiler, J.E., and Rougvie, J.R., 1999, Insights into the Proterozoic Geology of the Park Range, Colorado: Rocky Mountain Geology, v. 34, p. 7-20.

Fox, O.C., Sheehan, A.F., Dueker, K.G., Zurek, B., 2001, Seismic anisotropy across the Cheyenne belt, Southern Wyoming: Eos Transactions of the American Geophysical Union, v. 82 (47), Fall Meeting Supplements, Abstract S21F-10. 
Freeman, B., Klemperer, S.L., and Hobbs, R.W., 1988, The deep structure of northern England and the Iapetus suture zone from BIRPS deep seismic reflection profiles: Journal of the Geological Society of London, v. 145, p. 727-740.

Frost, C.D. and Frost, B.R., 1997, Reduced rapakivi-type granites: The tholeiite connection: Geology, v.25, p.647-650.

Genrich, Joachim F.; Bock, Yehuda; McCaffrey, Robert; Calais, Eric; Stevens, Colleen W., and Subarya, Cecep; 1996, Accretion of the southern Banda arc to the Australian plate margin determined by Global Positioning System measurements: Tectonics, v. 15, p. 288-295.

Graff, P.J., 1978, Geology of the lower part of the early Proterozoic Snowy Range Supergroup, Sierra Madre, Wyoming - with chapters on Proterozoic regional tectonics and uraniferous quartz-pebble conglomerates [PhD. Thesis]: Laramie, University of Wyoming.

Hamilton, W., 1979, Tectonics of the Indonesian region: USGS Professional Paper 1078.

Hawkins, D.P., Bowring, S.A., Bradley, R.I., Karlstrom, K.E., and Williams, M.L., 1996, $\mathrm{U}-\mathrm{Pb}$ geochronologic constraints on the Paleoproterozoic crustal evolution of the Upper Granite Gorge, Grand Canyon, Arizona: Geological Society of America Bulletin, v. 108, p. 1167-1181.

Hill, B.M. and Bickford, M.E., 2001, Paleoproterozoic rocks of central Colorado: Accreted arcs or extended older crust?: Geology, v. 29, p. 1015-1018.

Hills, F.A. and Armstrong, R.L., 1974, Geochronology of Precambrian rocks in the Laramie Range and implications for the tectonic framework of Precambrian southern Wyoming: Precambrian Research, v. 1, p. 213-225.

Hills, F.A. and Houston, R.S., 1979, Early Proterozoic tectonics of the central Rocky Mountains, North America: University of Wyoming Contributions to Geology, v. 17, p. 89-109.

Hirth, G. and Tullis, J., 1992, Dislocation creep regimes in quartz aggregates: Journal of Structural Geology, v. 14, p. 145-159.

Houston, R.S. and 15 others, 1968, A regional study of rocks of Precambrian age in that part of the Medicine Bow Mountains lying in southeastern Wyoming, with a chapter on the relationship between Precambrian and Laramide structure: Wyoming Geological Survey Memoir 1, 167 pp.

Houston, R.S., Erslev, E.A., Frost, C.D., Karlstrom, K.E., Page, N.J., Zientek, M.L., Reed, J.C., Snyder, G.L., Worl, R.G., Bryant, B., Reynolds, M.W., and Peterman, 
Z.E., 1993, The Wyoming Province, in Precambrian: Conterminous U.S., Geological Society of America, Inc., Reed, J.C., Bickford, M.E., Houston, R.S., Link, P.K., Rankin, D.W., Sims, P.K., and Van Schmus, W.R., eds.

Houston, R.S., and Graff, P.J., 1995, Geologic map of Precambrian rocks of the Sierra Madre, Carbon County, Wyoming, and Jackson and Routt Counties, Colorado: U.S. Geological Survey Miscellaneous Investigations Series, Map I-2452.

Houston, R.S., Karlstrom, K.E., Graff, P.J., and Flurkey, A.J., 1992, New stratigraphic subdivisions and redefinition of subdivisions of late Archean and early Proterozoic metasedimentary and metavolcanic rocks of the Sierra Madre and Medicine Bow Mountains, southern Wyoming: U.S. Geological Survey Professional Paper 1520.

Houston, R.S., Karlstrom, K.E., Hills, F.A., and Smithson, S.B., 1979, The Cheyenne belt: A major Precambrian crustal boundary in the western United States: Geological Society of America Abstracts with Programs, v. 11, p. 446.

Houston, R.S. and McCallum, M.E., 1961, Mullen Creek; Nash Fork shear zone, Medicine Bow Mountains, southeastern Wyoming: Geological Society of America Special Paper 68, 91 pp.

Houston, R.S., Schuster, J.E., and Ebbett, B.E., 1975, Preliminary report on the distribution of copper and platinum group metals in mafic igneous rocks of the Sierra Madre, Wyoming: U.S. Geological Survey Open-File Report 75-85, 129 pp.

Ilg, B.R., Karlstrom, K.E., Hawkins, D.P., Williams, M.L., 1996, Tectonic evolution of Paleoproterozoic rocks in the Grand Canyon: Insights into middle-crustal processes: GSA Bulletin, v.108, p. 1149-1166.

Jessup, M.J., Karlstrom, K.E., Livacarri, R., Connelly, J., Tyson, A., Rogers, S., 2002, Complex Proterozoic crustal assembly of southwestern North America involving northeast, then northwest, directed convergence in an arcuate subduction system: The Black Canyon of the Gunnison, southwestern Colorado, in press.

Karhu, J.A., 1993, Paleoproterozoic evolution of the carbon isotope ratios of sedimentary carbonates in the Fennoscandian Shield: Bulletin of the Geological Survey of Finland, Report no. 371, 87 pp.

Karlstrom, K.E., 1977, Geology of the Proterozoic Deep Lake Group, central Medicine Bow Mountains, Wyoming [M.S. thesis]: Laramie, University of Wyoming.

-1989, Early recumbent folding during Proterozoic orogeny in central Arizona: Geological Society of America Special Paper 235, p. 155-172. 
Karlstrom, K.E. and Bowring, S.A., 1988, Early Proterozoic assembly of tectonostratigraphic terranes in southwestern North America: Journal of Geology, v. 96, p. 561-576.

-----, 1993, Proterozoic orogenic history of Arizona, in Van Schmus, W.R., Bickford, M.E., and 23 others, Transcontinental Proterozoic Provinces, in Reed, J.C., Jr. and 6 others, eds., Precambrian: Conterminous U.S.: Boulder, Colorado, Geological Society of America, The Geology of North America, v.C-2, p. 188-211.

Karlstrom, K.E., and the CDROM Working Group, 2002, Structure and evolution of the lithosphere beneath the Rocky Mountains: Initial results from the CD-ROM experiment: GSA Today, v. 12, no. 3, p. 4-10.

Karlstrom, K.E., Flurkey, A.J., and Houston, R.S., 1983, Stratigraphy and depositional setting of Early Proterozoic metasedimentary rocks in southeastern Wyoming: record of an Early Proterozoic Atlantic-type cratonic margin: Geological Society of America Bulletin, v. 94, p. 1257-1294.

Karlstrom, K.E. and Houston, R.S., 1979, Stratigraphy of the Phantom Lake Metamorphic Suite and Deep Lake Group and a review of the Precambrian tectonic history of the Medicine Bow Mountains: Contributions to Geology, v. 17, p. 111-133.

-----1984, The Cheyenne belt; Analysis of a Proterozoic suture in southern Wyoming: Precambrian Research, v. 25, p. 415-446.

Karlstrom, K.E. and Humphreys, E.D., 1998, Persistent influence of Proterozoic accretionary boundaries in the tectonic evolution of southwestern North American: Interaction of cratonic grain and mantle modification events. Rocky Mountain Geology, v.33, p.161-179.

Karlstrom, K.E. and Williams, M.L., in press, Nature of the middle crust - heterogeneity of structure and process due to pluton-enhanced tectonism: an example from Proterozoic rocks of the North American southwest.

Karlstrom, K.E. and Williams, M.L., 1998, Heterogeneity of the middle crust: Implications for strength of continental lithosphere: Geology, v. 26, p. 815-818.

de Keijzer, M., Williams, P.F., and Brown, R.L., 2001, Kilometre-scale folding in the Teslin zone, northern Canadian Cordillera, and its tectonic implications for the accretion of the Yukon-Tanana terrane to North America: Canadian Journal of Earth Sciences, v. 36, p. 479-494. 
Keller, G.R., Karlstrom, K.E., Farmer G.L., 1999, Tectonic evolution in the Rocky Mountain region: 4-D imaging of the continental lithosphere: Eos, Transactions, American Geophysical Union, v.80.

Kennedy, S.G., 1992, The geology of the Proterozoic rocks in Mica Basin, northern Park Range, Colorado [M.S. thesis]: Iowa City, University of Iowa, 107 pp.

Klemperer, Simon L., 1989, Short Paper: Seismic reflection evidence for the location of the Iapetus suture west of Ireland: Journal of the Geological Society, London, v. 146, p. 409-412.

Klemperer, Simon L. and Matthews, Drummond H., 1987, Iapetus suture located beneath the North Sea by BIRPS deep seismic reflection profiling: Geology v. 15, p. 195198.

Klipfel, P.D., 1992, Geology and metallogeny of the southern portion of the encampment district, Colorado and Wyoming [M.S. thesis]: Iowa City, University of Iowa, 244 pp.

Knight, S.H. and Keefer, D.K., 1966, Preliminary report on the Precambrian stromatolites in the Nash Formation, Medicine Bow Mountains, Wyoming: Contributions to Geology, University of Wyoming, v. 5, p. 1-11.

Klipfel, P.D., 1992, Geology and metallogeny of the southern portion of the encampment district, Colorado and Wyoming [M.S. thesis]: Iowa City, University of Iowa, 244 pp.

Leeman, W.P., Oldow, J.S., and Hart, W.K., 1992, Lithospheric-scale thrusting in the western U.S. Cordillera as constrained by $\mathrm{Sr}$ and $\mathrm{Nd}$ isotopic transitions in Neogene volcanic rocks: Geology, v. 20, p. 63-66.

Lester, A. and Farmer, G.L., 1998, Lower crustal and upper mantle xenoliths along the Cheyenne belt and vicinity: Rocky Mountain Geology, v. 33, p. 293-304.

Livelybrooks, Dean and Banks, Roger J., 1995, Boundary between paleoplates investigated with several techniques: EOS, Transactions, American Geophysical Union, v. 76 no. 31, p. 305-312.

Low, P.C., Seaman, S.J., Karlstrom, K.E., and Williams, M.L., 2002, Proterozoic ultramafic rocks in southwestern North America: Distinguishing ophiolites from arc cumulates: Geological Society of America Abstracts with Programs, Annual Meeting, Paper no. 80-5.

McCaffrey, R., 1988, Active tectonics of the eastern Sunda and Banda arcs: Journal of Geophysical Research v. 93, p. 15163-15182. 
McCallum, M.E., 1964a, Cataclastic migmatites of the Medicine Bow Mountains, Wyoming: Contributions to Geology, University of Wyoming, v. 3, p. 78-88.

------, 1964b, Dedolomitized marble lenses in shear zone tectonites, Medicine Bow Mountains, Wyoming [abs.]: Geological Society of America Special Paper 82, p. 128-130.

Montel, J., Foret, S., Veschambre, M., Nicollet, C., and Provost, A., 1996, Electron microprobe dating of monazite: Chemical Geology 131, p.37-53.

Moores, E.M., 1982, Origin and emplacement of ophiolites: Reviews of Geophysics and Space Physics, v. 20, p. 735-760.

Morozova, E.A., Wan, X., Chamberlain, K.R., Smithson, S.B., Dueker, K., Johnson, R., Karlstrom, K.E., and Tyson, A.R., 2002, Interwedging nature of the Cheyenne belt - Archean-Proterozoic suture from seismic reflection data: Geophysical Research Letters, in press.

Nur, A. and Ben-Avraham, Z., 1982, Oceanic plateaus, the fragmentation of continents, and mountain building: Journal of Geophysical Research, v. 87, no. B5, p. 36443661.

Oliver, D.H., Hansen, V.L., de Keijzer, M., Williams, P.F., and Brown, R.L., 2001, Kilometre-scale folding in the Teslin zone, northern Canadian Cordillera, and its tectonic implications for the accretion of the Yukon-Tanana terrane to North America: Discussion and Reply: Canadian Journal of Earth Sciences, v. 38, p. 879-887.

Pallister, J.C. and Aleinikoff, J.N., 1987, Gabbroic plutons south of the Cheyenne belt: Underpinnings of an early Proterozoic continental margin arc: Geological Society of America Abstracts with Programs, v. 19, p. 325.

Premo, W.R., 1983, U-Pb zircon geochronology of some Precambrian rocks in the Sierra Madre Range, Wyoming [M.S. Thesis]: Lawrence, University of Kansas, 106 pp.

Premo, W.R. and Van Schmus, W.R., 1989, Zircon geochronology of Precambrian rocks in southeastern Wyoming and northern Colorado, in Grambling, J.A. and Tewksbury, B.J., eds., Proterozoic geology of the southern Rocky Mountains: Geological Society of America Special Paper 223, p.13-32.

Reed, J.C., Bickford, M.E., Premo, W.R., Aleinikoff, J.N., and Pallister J.S., 1987, Evolution of the Early Proterozoic Colorado province: Constraint from U-Pb geochronology: Geology, v. 15, p. 861-865. 
Reed, J.C., Jr., Bickford, M.E., and Tweto, O., 1993, Proterozoic accretionary terranes of Colorado and Wyoming, in Van Schmus, W.R., Bickford, M.E., and 23 others, Transcontinental Proterozoic Provinces, in Reed, J.C., Jr. and 6 others, eds., Precambrian: Conterminous U.S.: Boulder, Colorado, Geological Society of America, The Geology of North America, v.C-2, p.211-228.

Rougvie, J.R., 1990, Petrology of marbles and calc-silicates of the northernmost Park Range of Colorado [Senior Honors' thesis]: Iowa City, University of Iowa, 35 pp.

Rougvie, J.R. and Carlson, W.D., 1997, Fluid-rock interaction history of Proterozoic rocks from the Northern Park Range, Colorado: Geological Society of America Abstracts with Programs, v.29, no.7, p.A-93.

Samson, S.D. and Patchett, P.J., 1991, The Canadian Cordillera as a modern analogue of Proterozoic crustal growth: Australian Journal of Earth Sciences, v. 38, p. 595611.

Scherrer, N.C., Engi, M., Gnos, E., Jakob, V., and Liechti, A., 2000, Monazite analysis; from sample preparation to microprobe age dating and REE quantification: Schweiz. Mineral. Petrogr. Mitt., v. 80, p.93-105.

Schmidt, T.G., 1983, Precambrian metavolcanic rocks and associated volcanogenic mineral deposits of the Fletcher Park and Green Mountain areas, Sierra Madre, Wyoming [M.S. thesis]: Laramie, University of Wyoming, $113 \mathrm{p}$.

Selverstone, J., Hodgins, M., Aleinikoff, J.N., and Fanning, C.M., 2000, Mesoproterozoic reactivation of a Paleoproterozoic transcurrent boundary in the northern Colorado Front Range: Implications for 1.7 - and 1.4-Ga tectonism: Rocky Mountain Geology, v. 35, p. 139-162.

Selverstone, J., Pun, A., Condie, K.C., 1999, Xenolithic evidence for Proterozoic crustal evolution beneath the Colorado Plateau: Geological Society of America Bulletin, v. 111, p. 590-606.

Shaw, C.A. and Karlstrom, K.E., 1999, The Yavapai-Mazatzal crustal boundary in the southern Rocky Mountains: Rocky Mountain Geology, v.34, p.37-52.

Shaw, C.A., Karlstrom, K.E., Williams, M.L., Jercinovic, M.J., McCoy, A.M., 2001, Electron microprobe monazite dating of ca. 1.7-1.63 and ca. 1.45-1.38 Ga deformation in the Homestake Shear Zone, Colorado: origin and evolution of a persistent intracontinental tectonic zone: Geology 29, 739-742.

Sheridan, R.E., Musser, D.L., Glover III, L., Talwani, M., Ewing, J.I., Holbrook, W.S., Purdy, G.M., Hawman, R., Smithson, S., 1993, Deep seismic reflection data of EDGE U.S. mid-Atlantic continental-margin experiment: Implications for 
Appalachian sutures and Mesozoic rifting and magmatic underplating: Geology, v. 21, p. 563-567.

Silver, L.T., 1965, Mazatzal orogeny and tectonic episodicity [abs.]: Geological Society of America Special Paper 82, p. 185.

Smith, G.A., 1990, Geology of Precambrian rocks on Farwell Mountain, Colorado [M.S. thesis]: Iowa City, University of Iowa, 97 pp.

Snelson, C.M., Rumpel, H., Keller, G.R., Prodehl, C., Miller, K.C., Harder, S.H., 2001, Velocity structure along the CD-ROM'99 seismic refraction/wide angle reflection experiment: Geological Society of America Abstracts with Programs, v. 33, no. 5.

Snyder, D.B., Prasetyo, H., Blundell, D.J., Pigram, C.J., Barber, A.J., Richardson, A., Tjokosaproetro, S., 1996, A dual doubly-vergent orogen in the Banda arc continent-arc collision zone as observed on deep seismic reflection profiles: Tectonics, v. 15, 34-53.

Snyder, G.L., 1978. Intrusive rocks northeast of Steamboat Springs, Park Range, Colorado: U.S. Geological Survey Professional Paper 1041, 42 pp.

Snyder, G.L., 1980, Geologic maps of the northernmost and central Park Range and southernmost Sierra Madre, Jackson and Routt Counties, Colorado: U.S. Geological Survey Miscellaneous Geologic Investigations Maps I-1112 and I1113, scale 1:48,000.

----- 1988, Precambrian petrochemistry of the northern Park Range, Colorado, and its implications for studies of crustal derivation: U.S. Geological Survey Professional Paper 1343, $116 \mathrm{p}$.

Soper, N.J., England, R.W., Snyder, D.B., Ryan, P.D., 1992, The Iapetus suture zone in England, Scotland and eastern Ireland: a reconciliation of geological and deep seismic data: Journal of the Geological Society, London, v. 149, p. 697-700.

Spear and Cheney, 1989, A petrogenetic grid for pelitic schists in the system $\mathrm{SiO}_{2}-\mathrm{Al}_{2} \mathrm{O}_{3}-$ FeO-MgO- $\mathrm{K}_{2} \mathrm{O}-\mathrm{H}_{2} \mathrm{O}$ : Contributions to Mineralogy and Petrology, v. 101, no. 2, p. 149-164.

Tikoff, B. and Greene, D., 1997, Stretching lineations in transpressional shear zones; an example from the Sierra Nevada Batholith, California: Journal of Structural Geology, v. 19, no. 1, p. 29-39.

Tullis, J., and Yund, R. A., 1985, Dynamic recrystallization of feldspar: a mechanism for ductile shear zone formation: Geology, v.13, p. 238-241. 
Tweto, O., 1976, Geologic map of the Craig Quadrangle, northwestern Colorado: U.S. Geological Survey Miscellaneous Investigations Series Map I-972.

Tyson, A.R., Karlstrom, K.E., Chamberlain, K.R., Morozova, E.A., Smithson, S.B., Dueker, K., and Foster, C.T., 2002, Proterozoic Farwell Mountain -- Lester Mountain suture zone, northern Colorado: Subduction flip and progressive assembly of arcs: Geology, v.30, no.10, p.943-946.

White, C.A., 1987, Geology of Precambrian metasedimentary rocks of Lester Mountain, Colorado: A study of depositional environment, metamorphism and structure [M.S. thesis]: Iowa City, University of Iowa, 178 pp.

White, D.J., Zwanzig, H.V., and Hajnal, Z., Crustal suture preserved in the Paleoproterozoic Trans-Hudson orogen, Canada: Geology, v. 28, p. 527-530.

Williams, M.L. and Jercinovic, M.J., 2000a, Age mapping and dating of monazite on the electron microprobe: Implications for thermo-tectonic analysis of metamorphic rocks: GeoCanada 2000, 731.

------2000b, Application of electron microprobe age mapping and dating of monazite: Microscopy and Microanalysis 6 (Supplement 2), p. 406-407.

------, 2002, Microprobe monazite geochronology: putting absolute time into microstructural analysis: Journal of Structural Geology, v. 24, p. 1013-1028.

Williams, M.L., Jercinovic, M.J., Kopf, C., Hanmer, S., Baldwin, J., Bowring, S., 2000, Microprobe monazite geochronology: an essential tool for regional tectonothermal studies of the Western Churchill Province: GeoCanada 2000, 911.

Williams. M.L. and Karlstrom, K.E., 1996, Looping P-T paths and high-T, low-P middlecrustal metamorphism: Proterozoic evolution of the southwestern United States: Geology, v. 24, p. 1119-1122.

Wooden, J.L. and DeWitt, E., 1991, Pb isotopic evidence for the boundary between the early Proterozoic Mojave and central Arizona crustal provinces in western Arizona: Arizona Geological Society Digest, v.19, p.27-50. 


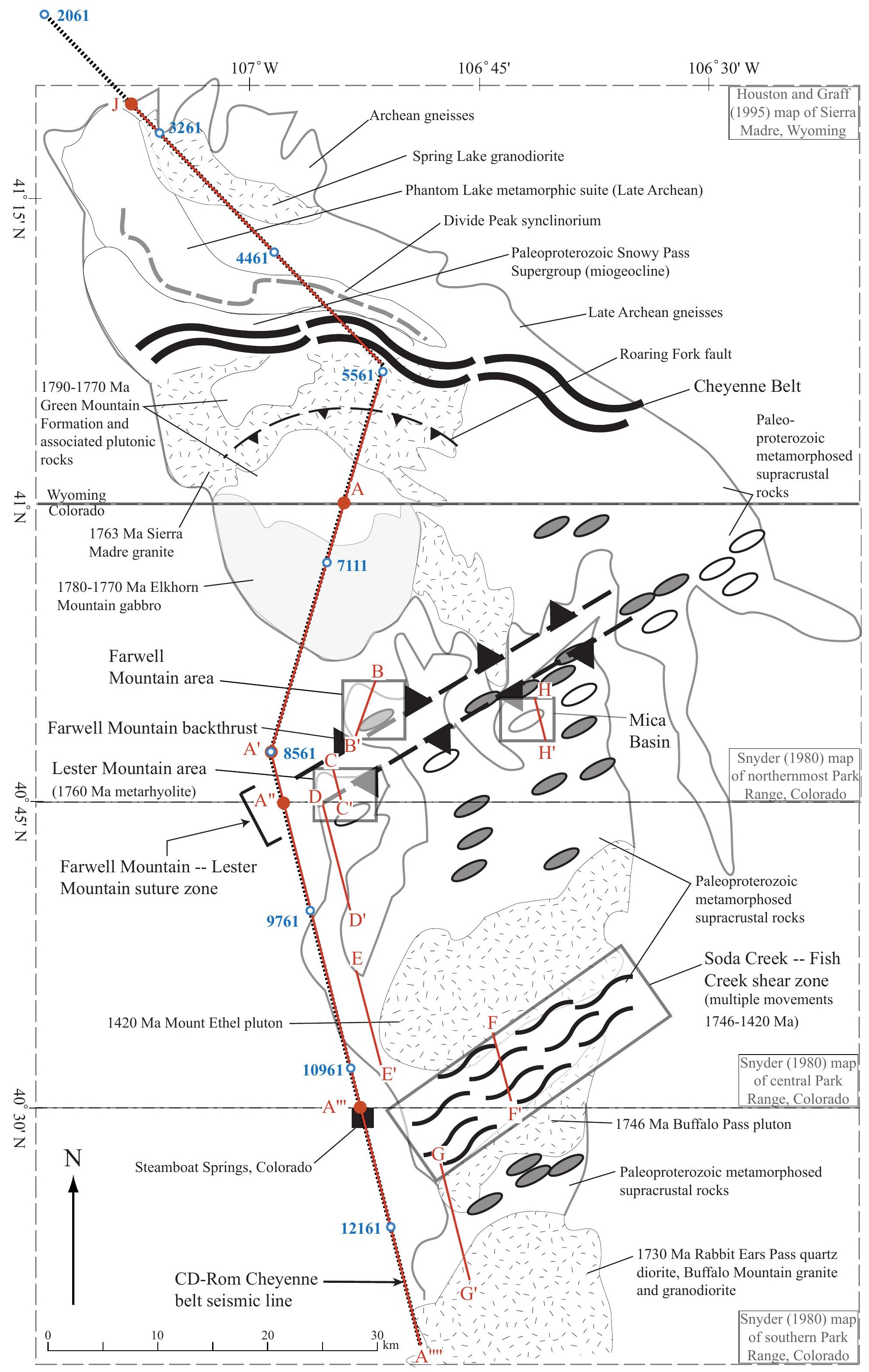

Plate 1a. Location map showing major lithologic packages in the southern Sierra Madre, Wyoming and Park Range, Colorado. Ages are approximate and are discussed in more detail in the main text and in Appendix A. CD-ROM Cheyenne belt seismic line (heavy dotted line) and geologic cross section line A-A"'" (red) are shown with cdp markers in blue. Geologic cross sections along B-B' through H-H' have been projected into A-A"'" (Plate 2). Gray boxes enclose the four subareas. Open ovals---rock with sillimanite pods; gray ovals--ultramafic bodies and deformed pillow basalts. Refer to Plates $1 \mathrm{~b}$ and $1 \mathrm{c}$ for detailed field maps of the Lester Mountain and Mica Basin areas, respectively. 


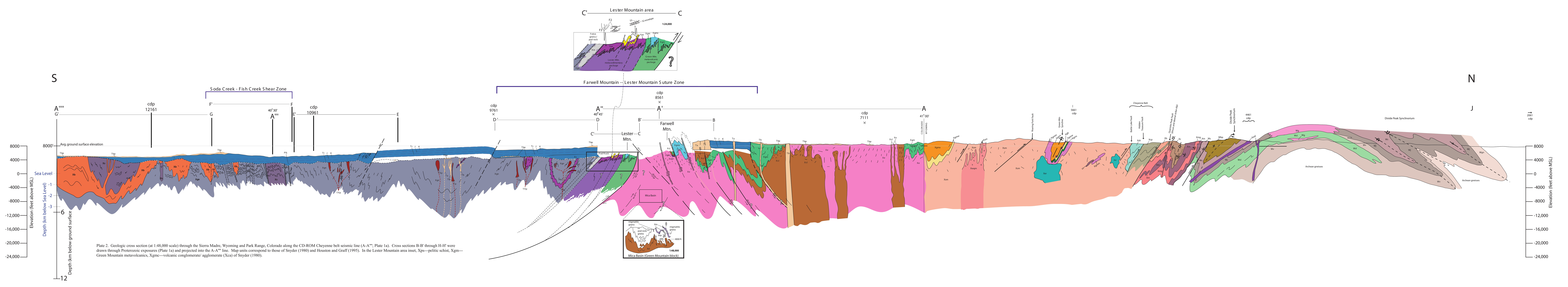




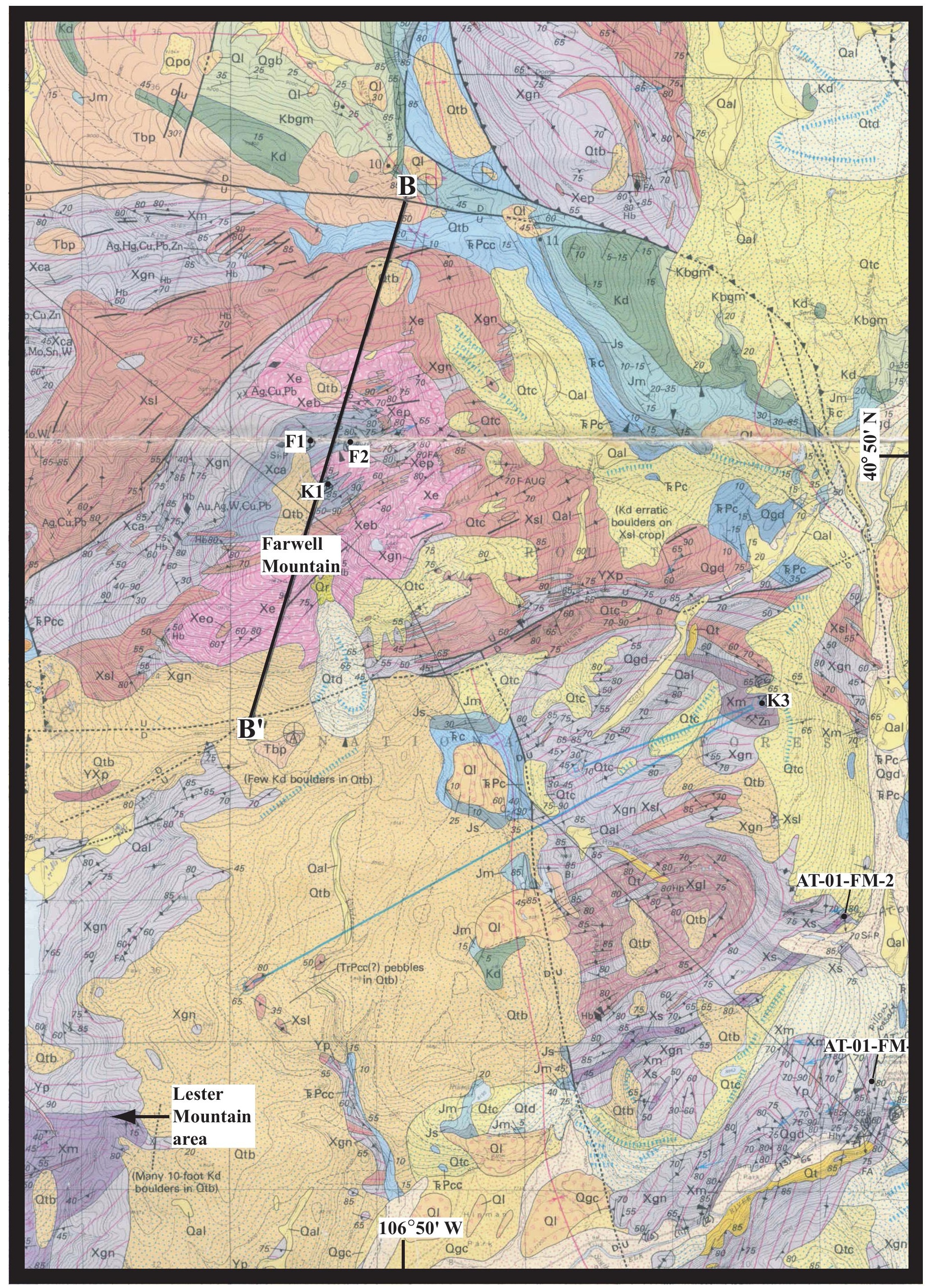

Plate 3. Geologic map of Farwell Mountain area at 1:48,000 scale excerpted from Snyder (1980). Station numbers represent sample locations as listed in Tables 1 and 2. Xe---Elkhorn Mountain gabbro; Xsl--Seven Lakes granite and granodiorite; Xgn---metavolcanic and metasedimentary gneisses; pink asterices--sillimanite pod rock. 


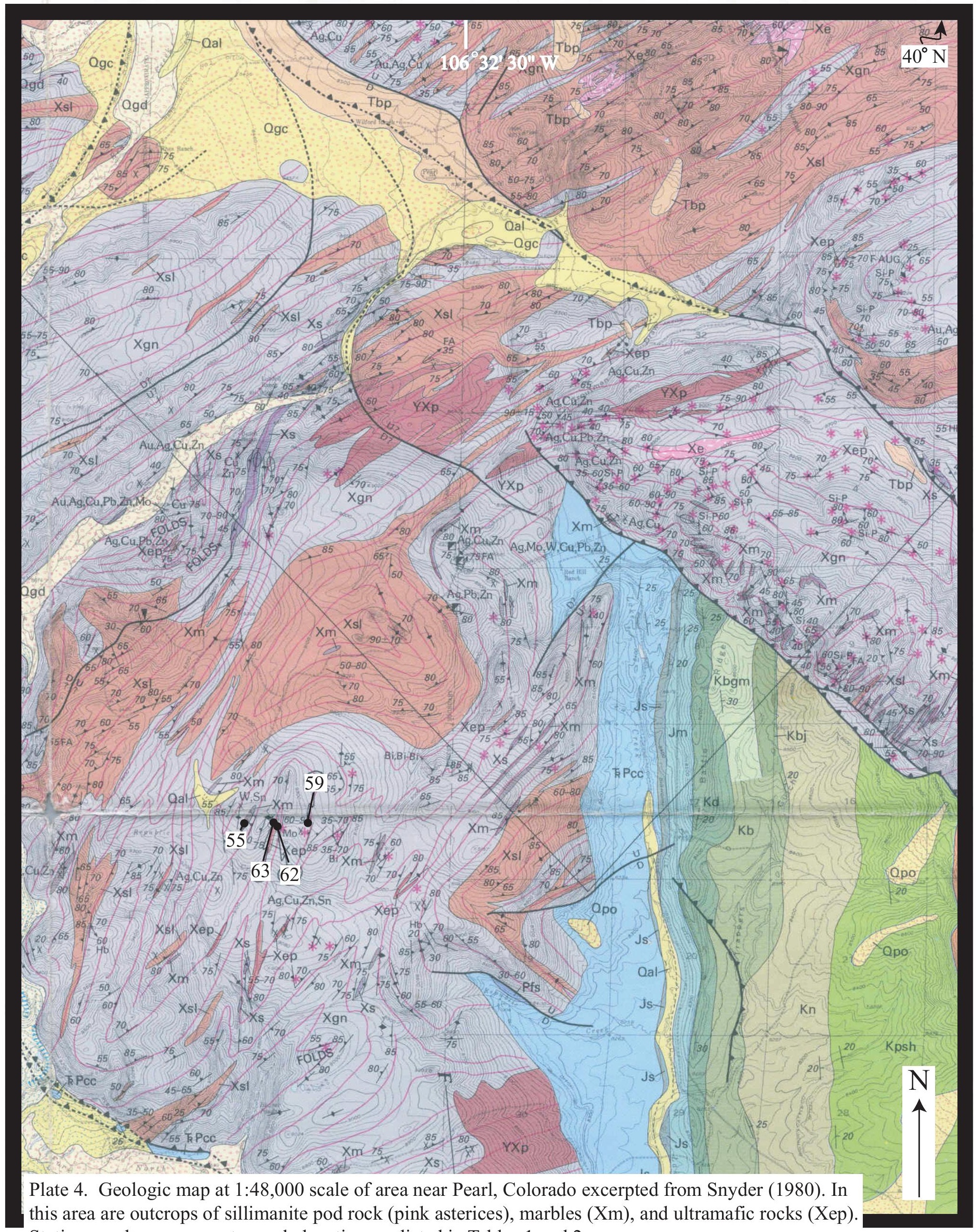

Station numbers represent sample locations as listed in Tables 1 and 2. 
Plate 5. Mica Basin

sample location map

\section{Explanation}

$\mathrm{S}_{0}=$ Bedding

$\mathrm{S}_{2}$ tectonic layering (foliation)

$\mathrm{S}_{3}$ tectonic layering (foliation)

Dominant tectonic layering (foliation); $\mathrm{S}_{1}$ or $\mathrm{S}_{2}$

Overturned bedding $\left(\mathrm{S}_{0}\right)$

Cross bedding $\left(\mathrm{S}_{0}\right)$

\section{Description of Map Units}

Xs1 Seven Lakes granite, quartz monzonite, granodiorite mingled with small gabbroic bodies (Elkhorn Mountain gabbro)

$\mathrm{Xm}$ Interlayered bodies of marble, calc-silicate rock, amphibolite, and/or chert (Snyder, 1980)

Xgn Felsic gneiss to amphibolite metavolcanics, approximately 50\% felsic and 50\% mafic interlayered gneisses (Snyder, 1980)

Xs Pelitic schist (metashale; Snyder, 1980) or mica-rich gneisses bearing sillimanite pods

Xp, Yp are felsic intrusive bodies of unknown Precambrian X or Y age, respectively (Snyder, 1980). Qal is Quaternary alluvium, undivided. 


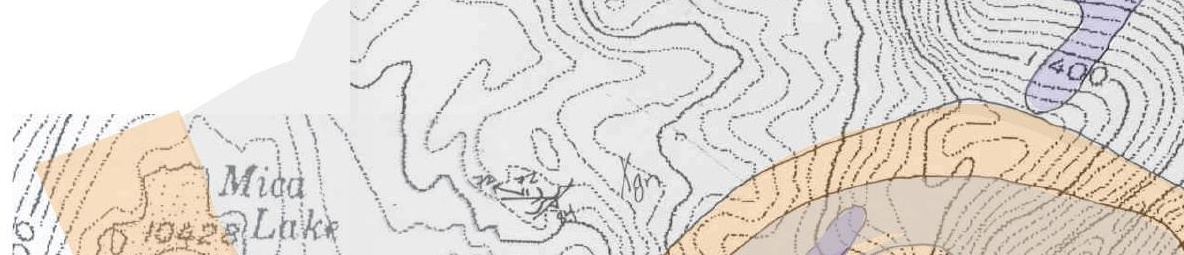

o/10 10428Lakk
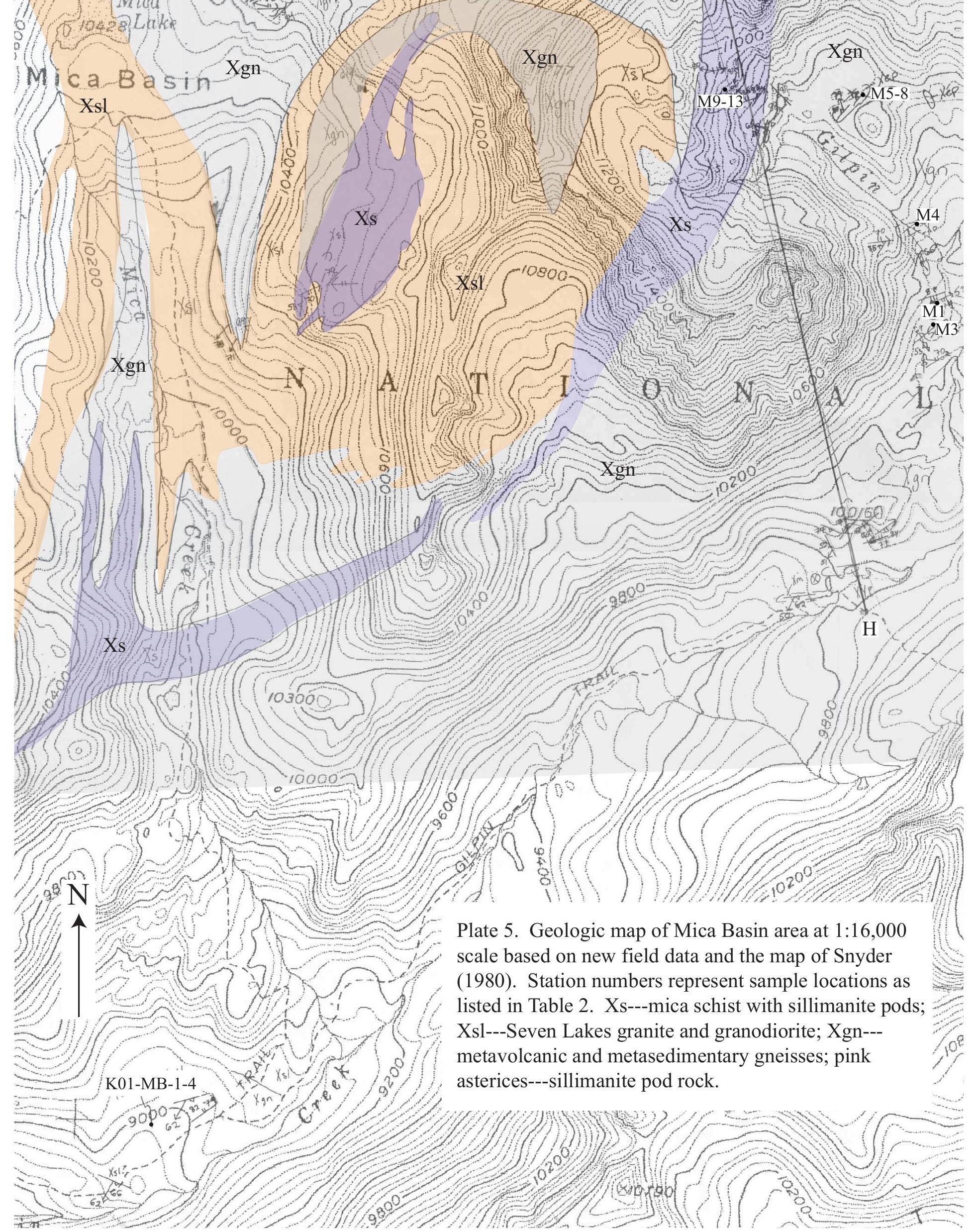


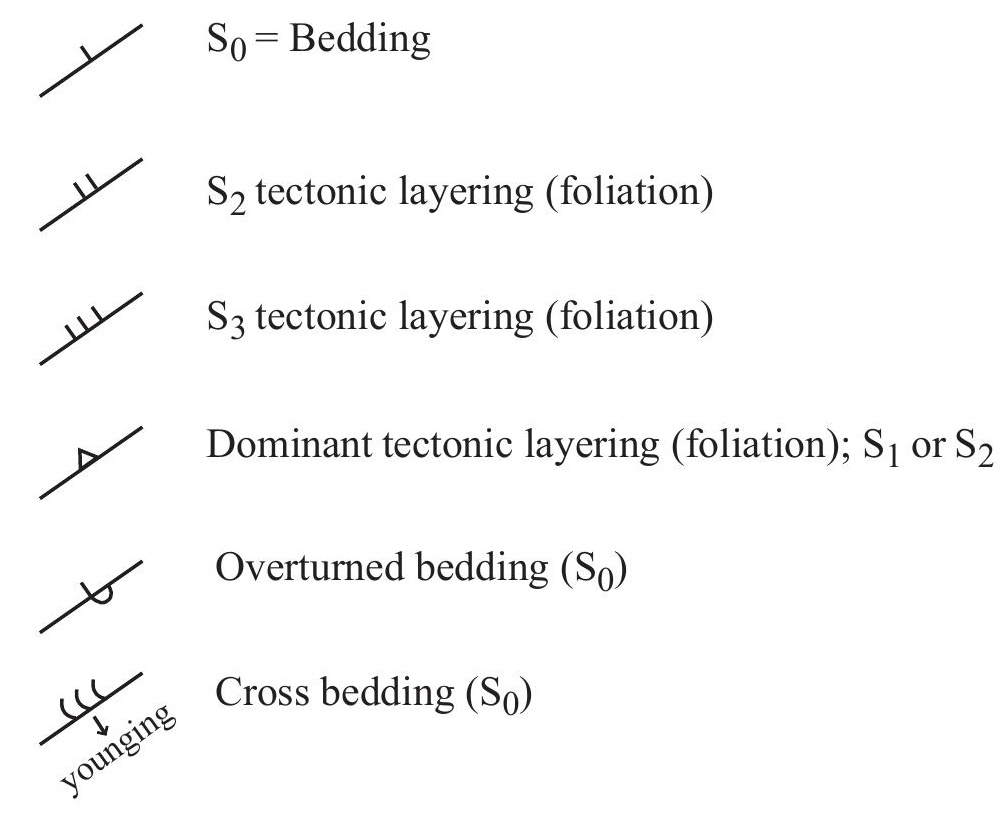

\section{Description of Map Units}

Xq Quartzite, massive to bedded (Snyder, 1980; metamorphosed quartz arenite; Foster et al., 1999)

Xmq Micaceous quartzite (metamorphosed cross-bedded sublitharenite) bearing garnet and sillimanite pods

Xqs Quartz-mica schist (metamorphosed interlayered sandstones and shales, possibly graywackes). Mica content increases away from contact with Xmq

Xst Staurolite schist bearing sillimanite pods and rare garnet

$\mathrm{Xgb}$ Garnet-biotite schist bearing sillimanite pods

Xca Rhyodacitic metavolcanic-volcaniclastic conglomerate/agglomerate, correlated to Xca of Farwell Mountain (Snyder, 1980)

$\mathrm{Xm}$ Interlayered bodies of marble, calc-silicate rock, amphibolite, and/or chert (Snyder, 1980)

Xpla Amphibolite and hornblende-rich gneisses (White, 1987). Garbenschiefer texture present

Xpl Fine-grained quartz-biotite gneiss, quartzo-feldspathic gneiss, thin layers of amphibolite with calcareous "leopard" spots (White, 1987)

Xp, Yp are felsic intrusive bodies of unknown Precambrian X or Y age, respectively (White, 1987; Snyder, 1980). Qal is Quaternary alluvium, undivided. 


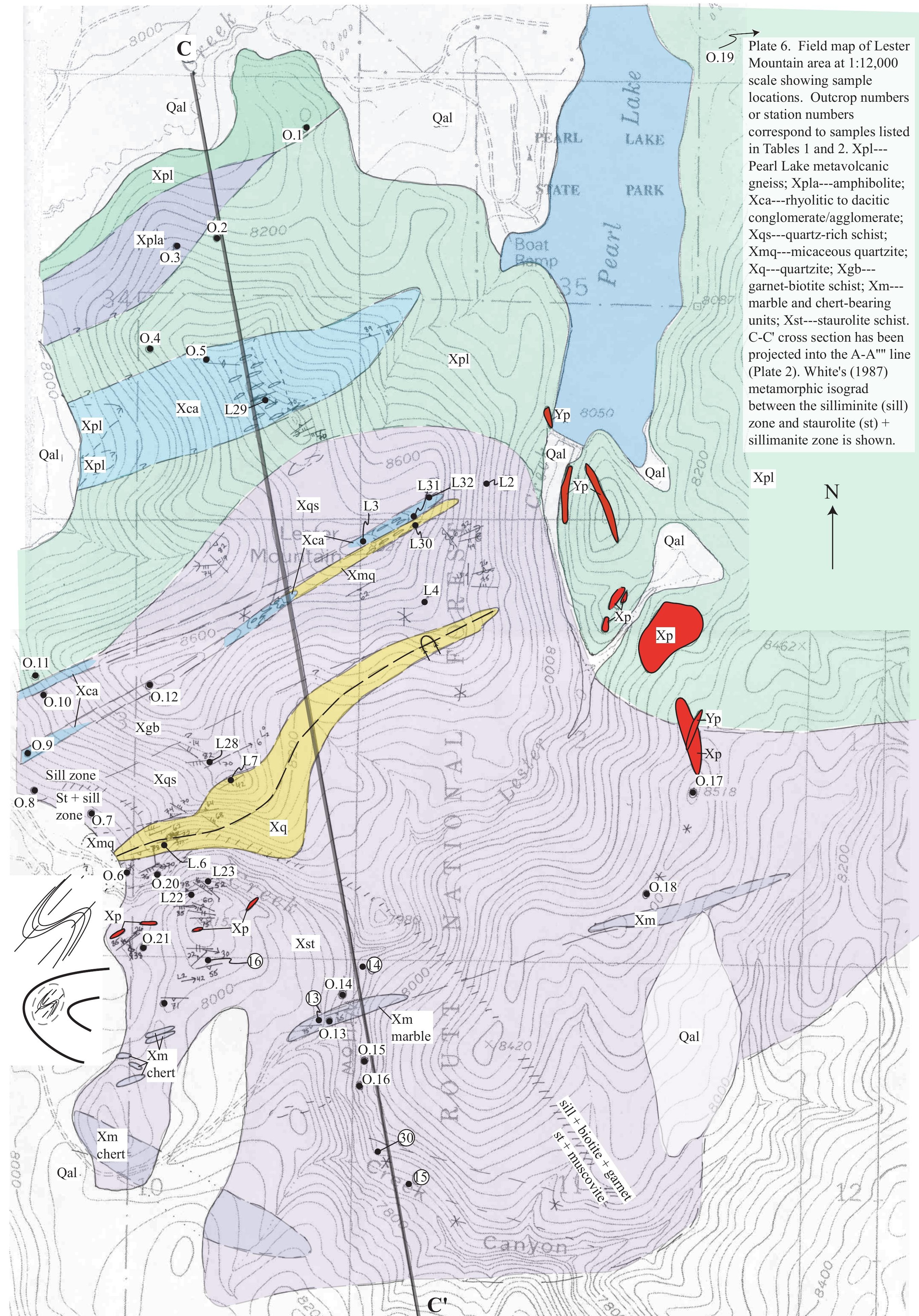




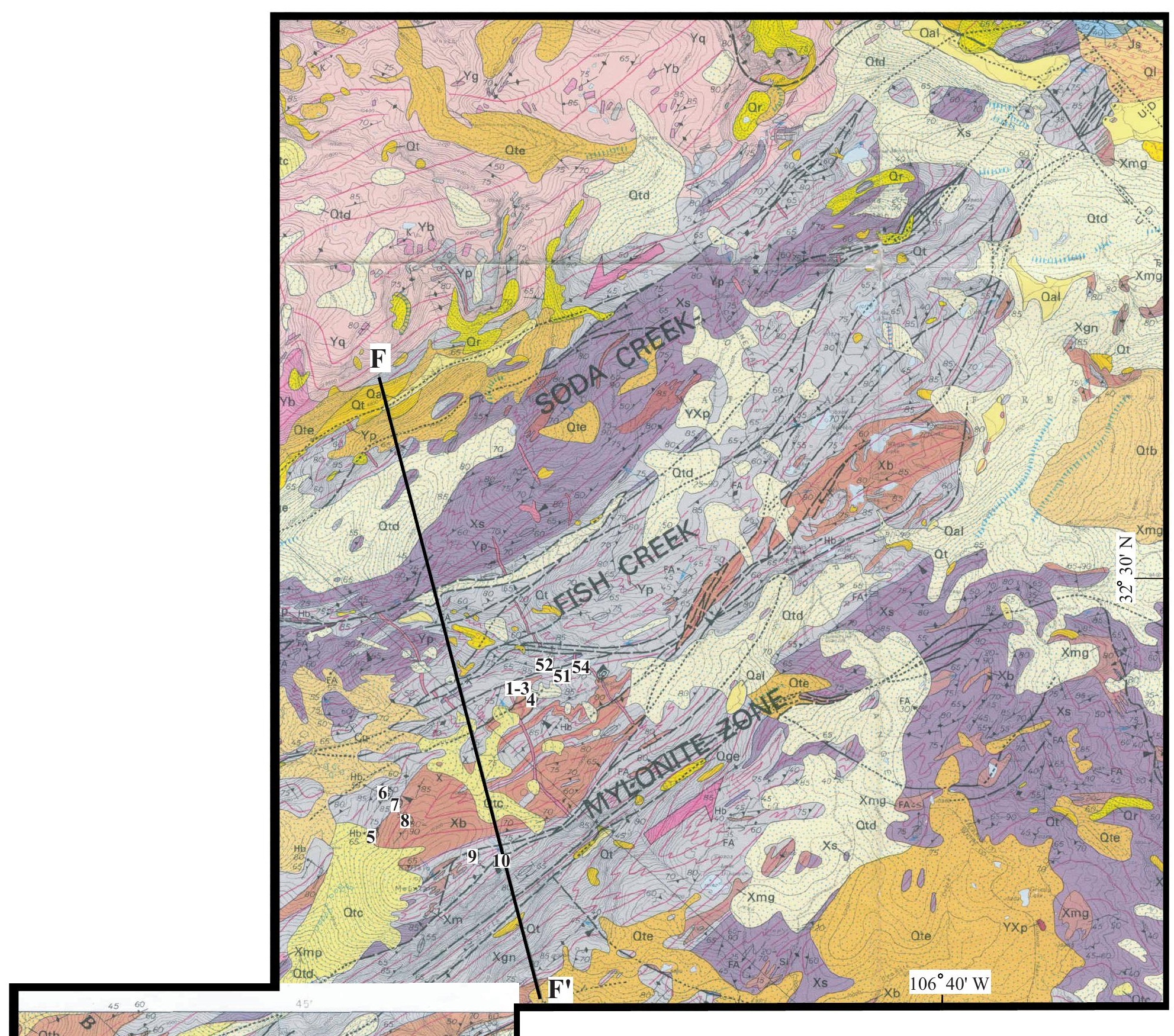

Plate 7. Geologic map of the Soda Creek --

Fish Creek shear zone at 1:64,000 scale

excerpted from Snyder (1980). Station

numbers represent sample locations as listed

in Tables 1 and 2. Xgn, Xs --- metavolcanic

and metasedimentary gneisses and schists; $\mathrm{Xb}$

--- Buffalo Pass pluton. Mylonites are

represented by heavy dashed lines.

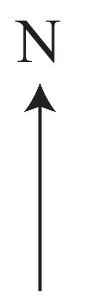




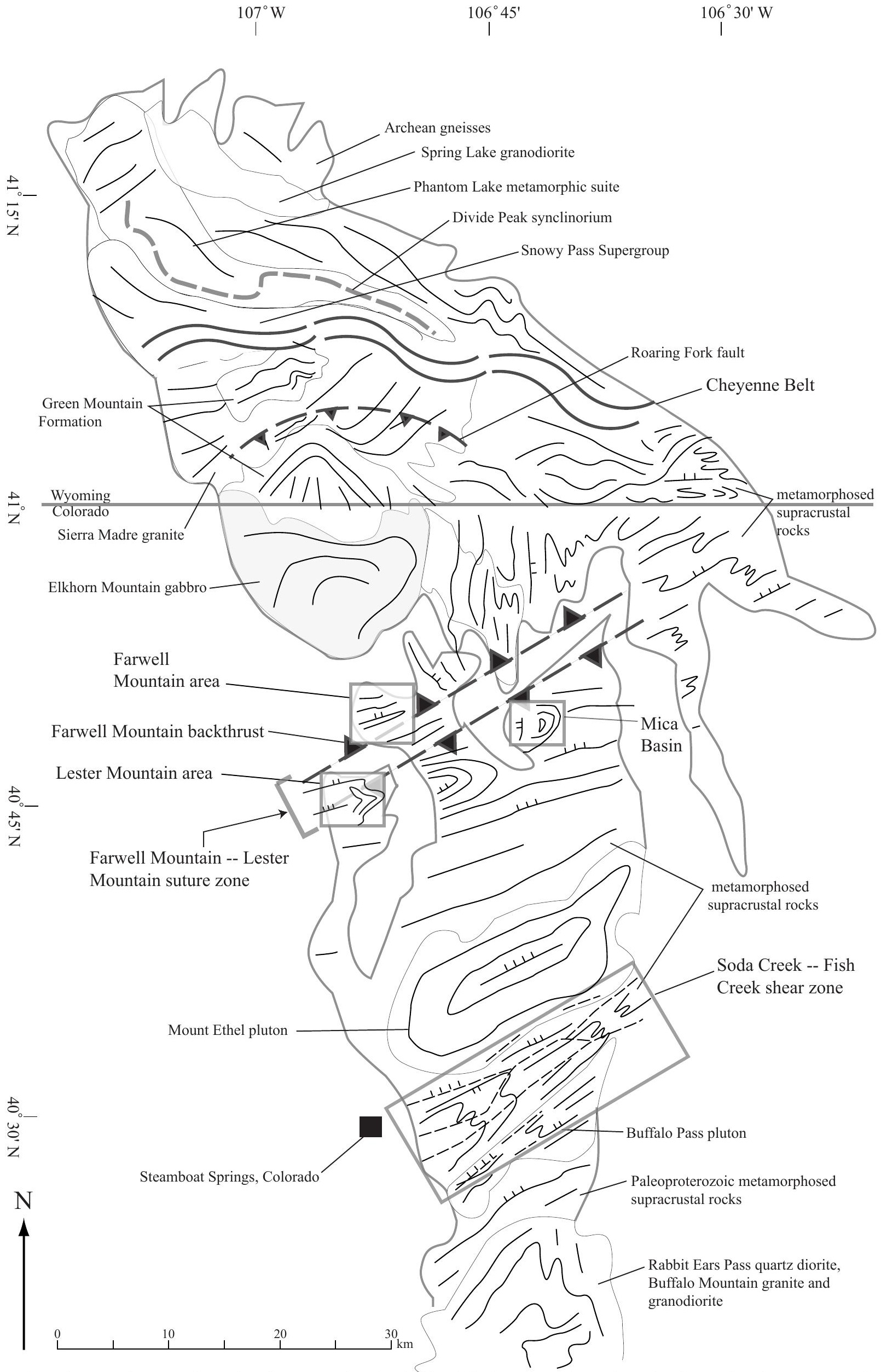

Plate 8. Map of southern Sierra Madre, Wyoming and Park Range, Colorado, showing foliation trajectories. Trajectories show strike of S0-S1 composite foliation unless otherwise labeled; two ticks represent S2, three S3, or four S4 orientations. Mylonites in the Soda Creek -- Fish Creek shear zone are shown schematically as heavy dashed lines. Gray boxes outline field subareas for which structural data is plotted on stereonets: Farwell Mountain area (Figure 3), Mica Basin area (Figure 4), Lester Mountain area (Figure 6), and Soda Creek -- Fish Creek shear zone (Figure 7). 
